\author{
UNIVERSIDADE DE SÃO PAULO \\ ESCOLA DE ARTES, CIÊNCIAS E HUMANIDADES \\ PROGRAMA DE PÓS-GRADUAÇÃO EM TÊXTIL E MODA
}

LAURA PICCININI

Um estudo do processo de desenvolvimento de produto no vestuário de moda na malharia retilínea no Brasil 



\title{
Um Estudo do Processo de Desenvolvimento de Produto no Vestuário de Moda na Malharia Retilínea no Brasil
}

\author{
Dissertação apresentada à Escola de Artes \\ Ciências e Humanidades da Universidade de \\ São Paulo para obtenção do título de Mestre \\ em Ciências pelo Programa de Pós-graduação \\ em Têxtil e Moda.
}

\begin{abstract}
Versão corrigida contendo as alterações solicitadas pela comissão julgadora em 17 de setembro de 2015. A versão original encontrase em acervo reservado na Biblioteca da EACH/USP e na Biblioteca Digital de Teses e Dissertações da USP (BDTD), de acordo com a Resolução CoPGr 6018, de 13 de outubro de 2011.
\end{abstract}

Área de concentração:

Têxtil e Moda

Orientadora:

Prof $^{\text {a. }}$ Dra. Francisca Dantas Mendes

São Paulo 

estudo e pesquisa, desde que citada a fonte.

Piccinini, Laura

Um estudo do processo de desenvolvimento de produto no vestuário de moda na malharia retilínea no Brasil / Laura Piccinini ; orientadora, Francisca Dantas Mendes. - São Paulo, 2015 199 f. : il.

Dissertação (Mestrado em Ciências) - Programa de PósGraduação em Têxtil e Moda, Escola de Artes, Ciências e Humanidades, Universidade de São Paulo Versão corrigida

1. Indústria têxtil - Brasil. 2. Malharia - Brasil. 3. Vestuário - Fabricação - Brasil. 4. Desenvolvimento de produtos. I. Mendes, Francisca Dantas, orient. II. Título.

CDD 22.ed. -677.028245 
Nome: PICCININI, Laura

Título: Um estudo do processo de desenvolvimento de produto no vestuário de moda malharia retilínea no Brasil.

Dissertação apresentada à Escola de Artes Ciências e Humanidades da Universidade de São Paulo para obtenção do título de Mestre em Ciências do Programa de Pós-Graduação em Têxtil e Moda.

Área de Concentração:

Têxtil e Moda.

Aprovada em: I

Banca Examinadora:

Prof. Dr. Antonio Takao Kanamaru

Escola de Artes Ciências e Humanidades

da Universidade de São Paulo

Prof $^{a}$. Dra. Patrícia de Mello Souza

Departamento de Design de Moda da

Universidade Estadual de Londrina

Prof. Fernando José Carneiro Moreira Da Silva

Departamento de Design

Universidade de Lisboa

São Paulo 

DEDICATÓRIA

A meus pais Giulia e Albano, meus filhos Marília e Ricardo, que me apoiaram e incentivaram, com paciência, amor e carinho, durante todo o curso. 



\section{AGRADECIMENTOS}

A Deus, pela benção da vida.

A minha orientadora, Professora Francisca Dantas Mendes, pela dedicação e incentivo.

Aos professores colegas e funcionários do curso de Moda e Têxtil da Universidade São Paulo pelo aprendizado e troca de experiências.

A minha filha Marília que deu continuidade ao trabalho da família e pela dedicação, carinho e disponibilidade na minha vida.

A Paramalhas Stoll e Universidade de Caxias do Sul, especialmente a Lila Zambon pela recepção e informação em seus laboratórios de vestuário de Malharia Retilínea.

As empresas no Sul de Minas em que pude contribuir com meu trabalho em especial a Galera, Fortuito, Perfecta, Palank e Luiz Pinotti.

A minha irmã Nella Piccinini que acompanhou meu trabalho e contribuiu com dedicação durante os 20 anos nas duas empresas da família Malharia Giulia e Linea L'aura.

A minha mãe Giulia Dobelli Piccinini fundadora da empresa Malharia Giulia em 1964, como exemplo de profissional de alta qualidade. 



\section{RESUMO}

Piccinini, Laura. Um Estudo do Processo de Desenvolvimento de Produto no Vestuário de Moda na Malharia Retilínea no Brasil, 2015. 199 p. Dissertação (Mestrado em Ciências) - Escola de Artes Ciências e Humanidades (EACH) da Universidade de São Paulo, São Paulo, 2015.

Esse estudo contempla uma pesquisa bibliográfica sobre a malharia retilínea, seu processo produtivo, tecnologia, versatilidade criativa e processo de desenvolvimento de produto. Inclui uma pesquisa de campo no Polo Industrial do Sul de Minas Gerais (regiões de

Monte Sião e Águas de Lindóia), cidades de alta concentração de indústrias de Malharia retilínea.

O objetivo dessa dissertação é explorar o desenvolvimento de produto em Vestuário de Moda da Malharia Retilínea (VMMR), captando as variáveis que influenciam no grau de inovação dos produtos, bem como a capacidade de atingir o objetivo estético idealizado e a viabilidade produtiva.

Para atingir esse objetivo, apresenta-se a cadeia de suprimentos do produto de VMMR, bem como a evolução dos recursos tecnológicos das máquinas retilíneas. A fim de compreender o processo criativo no desenvolvimento de produto de moda em malharia retilínea, é fundamental examinar de perto a contribuição dos elos da cadeia de abastecimento. A percepção dos elos da cadeia é fundamental, pois o processo de criação evolui junto com o desenvolvimento tecnológico das máquinas e dos fios. No entanto, a inovação depende do conhecimento e interação consistente dos profissionais de criação, designers, modelistas e programadores de software.

A fim de compreender o processo de criação no desenvolvimento de produto e os desafios enfrentados pelos designers, é realizada uma pesquisa na história da malharia e conceitos de moda. Para desenvolver uma coleção a criatividade do estilista passa pela história pessoal, suas experiências e suas qualidades de estilo sobre determinada técnica manual e mental.

Com a intenção de importar de outras áreas conhecimentos importantes para o processo de desenvolvimento de produto no VMMR, também foram explorados alguns métodos de desenvolvimento de produto em engenharia, o que permite a divisão do processo de criação em etapas e a estruturação de conceitos. 
Por fim, foi realizada uma pesquisa de campo com dez empresas confeccionistas de VMMR e quatro empresas de referência do Polo Sul de Minas Gerais, através da qual foi possível identificar padrões aplicados no desenvolvimento de produto, seus processos criativos, bem como os seus níveis profissionais. Com isso, espera-se gerar informações importantes nesta pesquisa, a fim de contribuir para o desenvolvimento da indústria de vestuário em malharia retilínea.

Palavras-Chave: Malharia Retilínea. Desenvolvimento de Produto. Processos criativos. 


\begin{abstract}
Piccinini, Laura. A Study of Product Development Process in Fashion Clothes knitwear in Brazil. 2015, 199 p. Dissertation (Master of Science) - School of Arts, Sciences and Humanities, University of São Paulo, São Paulo, 2015.

This study covers literature research about knitwear, the production process, technology, creative versatility and product development. It also includes field research based in the south of Minas Gerais (regiões de Monte Sião, e Águas de Lindóia), a place with a high concentration of knitwear companies. The focus of the field research consists of case studies in ten industrial companies and three technological leading centres of the region.

The purpose of this dissertation is to explore the product development process in fashion clothes knitwear in Brasil, capturing the variables that influence the degree of product innovation, as well as the ability to achieve the idealized aesthetic goals, and to create viable products.

To explore this subject, the knitwear product supply chain is presented, as well as the evolution of technological resources, including flat knitting machines. In order to understand the creative process in fashion knitwear, it is critical to closely examine the contribution and influence of the extended supply chain. The supply chain is crucial because the process of product creation includes the technological development of machines and yarns. However, innovation also depends on the knowledge and robust interaction of fashion designers, product10 modelers and software programmers.

In order to understand the creation product development process and the challenges that have faced, and continue to face designers, and overview of the history of knitting and knitting technologies is explored.

Upon examination, it is possible to observe that there are several ways to develop a collection, as the designer creativity depends on his own specific experiences and ability with certain manual techniques and mental models.

In order to bring from other areas important knowledge for the development process in knitwear, it was also explored some product development methods in engineering, allowing the division of this process in structured concepts.
\end{abstract}


Finally, it was made a field research with ten clothing manufacturers companies and other important players in the South Minas Gerais Area, including two suppliers of knitting machines, through which it identified applicable standards of the product development of these companies as well as their professional levels.

It was expected to generate important information in this research, in order to contribute to the development of the knitting industry and their professionals.

Keywords: Knitwear. Product Development. Creative Processes. 


\section{LISTA DE FIGURAS}

Figura 1 - Polos de Malharia Retilínea no Brasil. Fonte: SEBRAE, 2012 …..................................... 29

Figura 2 - Produção mundial de fibras (Castiglione M., 2010)........................................................... 31

Figura 3 - Diferentes tipos de efeitos em torções e fantasia. Fonte: Medeiros (1999). ………............. 42

Figura 4 - Fios fantasia, exemplo de botonê, flame, mescla, felpado, frise. Fonte: Sissons, 2010....... 43

Figura 5 - Máquina de parafinar o fio, chamada espuladeira. Fonte: Malharia Gita, 2014................. 45

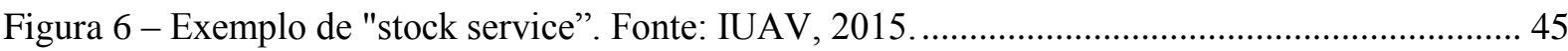

Figura 7 - Filo 2016/2017, Milão, tendência para o inverno, Knitting Industry.

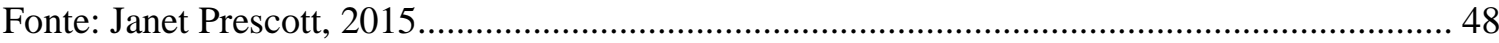

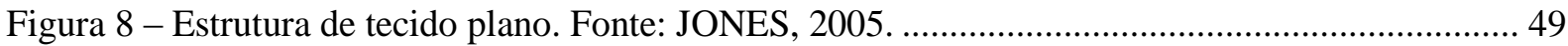

Figura 9 - Estrutura de tecido de malha. Fonte: JONES, 2005 .............................................................. 49

Figura 10 - Esquema de base de tecido de confecção de Malharia. Fonte: SEBRAE, 2012 ............... 50

Figura 11 - Máquina de tecer manual de uso caseiro. Fonte: SISSONS, 2011 ................................... 51

Figura 12 - Máquina de Malharia Manual da Universidade de Caxias do Sul. Fonte: UCS, 2014 ...... 51

Figura 13 - Máquina Eletrônica compacta de última geração. Fonte: Stoll, 2013................................ 52

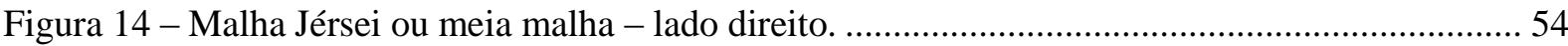

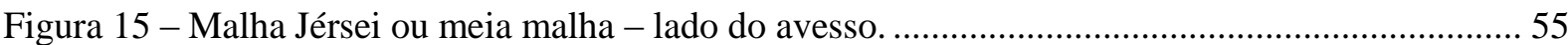

Figura 16 - Pontos mais usados nos tecidos de malha retilínea no produto de malha.

Fonte: Faerm, 2010.

Figura 17 - Instrumento para transferência de pontos entre as agulhas na máquina manual industrial.

Pulsão de transferência de pontos em método manual. Fonte: Laura Piccinini, IUAV, 2015 ...... 58

Figura 18 - Pontos de Máquina retilínea. Fonte: SISSONS, 2011, p. 76. 58

Figura 19 - Máquina retilínea, transferência de pontos, transferência de ponto.

Fonte: SISSONS, 2012, p. 76 58

Figura 20 - Tecido produzido em máquina retilínea manual com efeitos de trabalho feito com

transferência de pontos. Fonte: SISSONS, 2012, p.28

Figura 21 - Pontos Basicos em malharia retilínea Fonte:Laura Piccinini, 2015 IUAV.

Figura 22 - Desenhos de tranças construídos com transferências de pontos (registro do autor, 2015). 60

Figura 23 - Emenda da manga com calados de diminuição. (registro do autor, 2015). 61

Figura 24 - Tênis Nike, 2012. Produzido com tecnologia de Peça Pronta. Fonte: Stoll, 2012. 62

Figura 25 - Agulhas baixas e altas com acionamento de molas. Fonte: STOLL, 2012. 63 
Figura 26 - Malharia Retilínea, a figura apresenta jogo de porta fios. Fonte: STOLL, 2012.

Figura 27 - Sistema integrado de Desenvolvimento de Produto da Shima Seiki.

Fonte: Shima Seiki, 2012

Figura 28 - Ilustração do processo de modelagem da fabricante Shima Seiki, software

de modelagem. Fonte: Shima Seiki, 2010.

Figura 29 - Mostra de fios com coloração de pigmentos com corantes vegetais. Fonte: Pitti Filati,

2011.

Figura 30 - Visit of the Angel, conhecida como Knitting Madonna, Mestre Bertram de Minden, 1400.

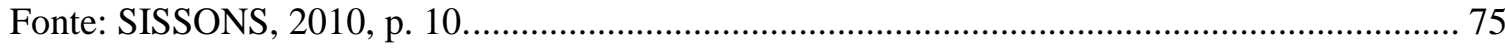

Figura 31 - Tear de pedal inventado por William Lee em 1589. Fonte: Sissons, 2010....................... 75

Figura 32 - Desenhos diferenciados com recursos de CMS em máquinas retilíneas. Fonte: STOLL

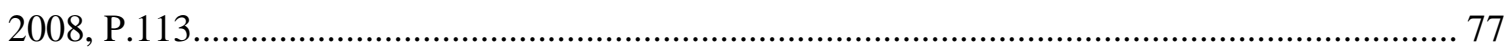

Figura 33 - Visualização da linguagem de informática e da real. Fonte: Malharia Gita, 2014............ 80

Figura 34 - Painel de imagens, inspiraçoes para coleção. Fonte: Laura Piccinini, IUAV, 2015.......... 81

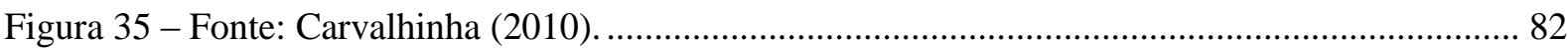

Figura 36 - Modelagem detalhada e escolha de tecido e textura, peso e

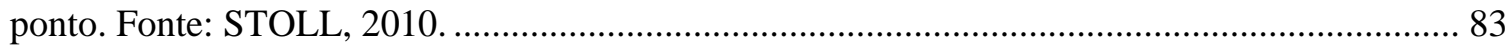

Figura 37 - Programação com tradução simultânea de linguagem real e simbólica de estilo e

modelagem na máquina eletrônica, operador de máquina inserindo o programa. Fonte: Stoll, 2010.

Figura 38 - Painel da máquina eletrônica, tradução simultânea da linguagem técnica para a real.

Fonte: STOLL, 2012.

Figura 39 - Ficha técnica simplificada de malharia retilínea de estilo, Monte Sião. Fonte: Laura

Piccinini, 2009

Figura 40 - Ficha técnica por Angela Aronne Marques, estilista, Monte Sião. Fonte: Laura Piccinini, 2008 .

Figura 41 - Cálculo de modelagem, aprendizado inicial em aula de VMMR.

Fonte: IUAV, Laura Piccinini. 92

Figura 42 - Manequim de Moulage, prova de Modelagem em tecido de malha.

Fonte: Laura Piccinini. 97

Figura 43 - Sala de modelagem em moulage da Universidade de Caxias do Sul, 2013

Figura 44 - Criatividade em modelagens com técnica de moulage em MR, Pitti Filati, Itália, 2011... 99 
Figura 45 - Remalhadeira, Malharia. Fonte: Laura Piccinini, 2014.

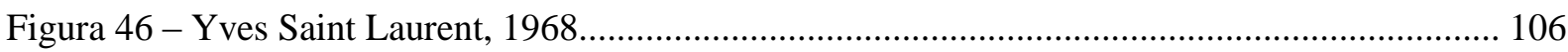

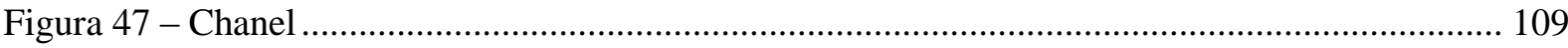

Figura 48 - Kenzo,1987-1988, p.186. Fonte: Maglifico.................................................................. 112

Figura 49 - Modelo da marca Emilio Pucci. Fonte: Pucci, 2010 ........................................................ 113

Figura 50 - Estudo de formas, cores e fios, Ottavio Missoni. Fonte: Missoni, 2006.......................... 115

Figura 51 - Produto da marca Missoni. Fonte: Missoni, 2006 ...................................................... 116

Figura 52 - Produto da marca Missoni. Fonte: Missoni, 2006........................................................ 116

Figura 53 - Moda em vestuário de malharia retilínea, padronagens da marca

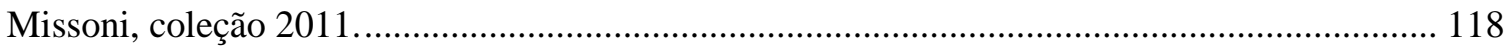

Figura 54 - Modelo tubolar sem costuras baguette design coleção ano 2000, Issey Miyake. Fonte:

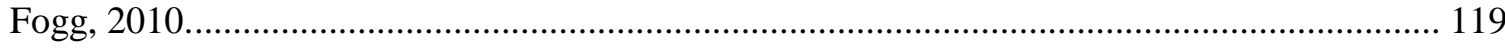

Figura 55 - Modelo MAPP-3A. Método desenvolvido por Mello, (2011)........................................ 121

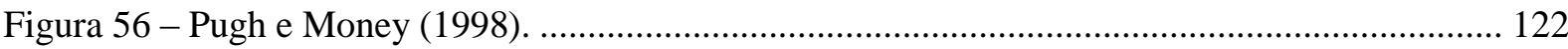

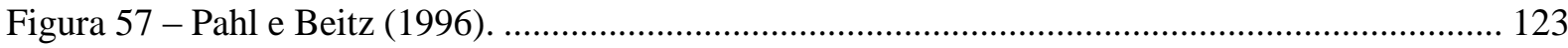

Figura 58 - Munari, destaca o processo criativo em etapas (2002) ................................................. 124

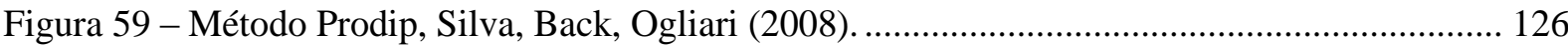

Figura 60 - Processo de desenvolvimento de produtos do VMMR Radial (elaboração da autora),

baseado no modelos MAPP-3A, utilizado como base para o roteiro de perguntas direcionadas.

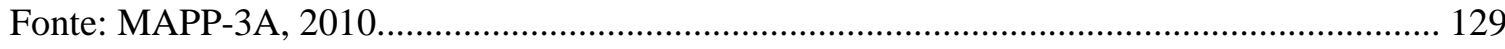

Figura 61 - Primeira máquina retilínea Stoll. Fonte: Stoll, 2008................................................... 138

Figura 62 - Máquina retilínea 1926, STOLL. Fonte: Stoll, 2008_.................................................... 139

Figura 63 - Primeira máquina retilínea com seleção eletrônica de agulhas individual, lançada na

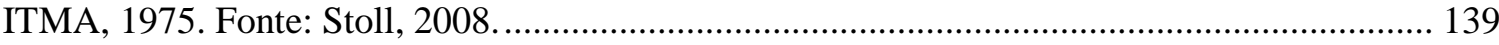

Figura 64 - Tecnologia de tecer nas máquinas as partes moldadas - fully fashioned - e sua evolução

para peça pronta - Wholegarment. Fonte: Stoll, 1990................................................................ 140

Figura 65 - Visualização de duas telas, real na primeira tela e técnica na segunda tela. Fonte: Stoll, 2012.

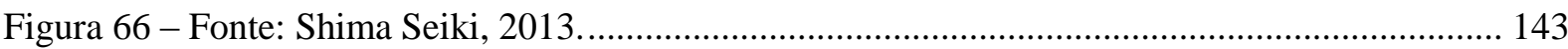

Figura 67 - Interação entre profissionais especialistas no processo criativo do VMMR. Fonte: Laura

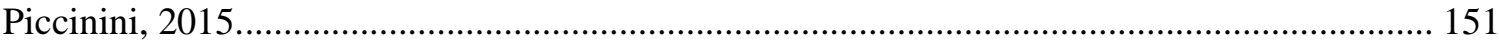

Figura 68 - Processo de Desenvolvimento de Produto adaptado do MAPP-3A................................. 157 


\section{LISTA DE TABELAS}

Tabela 1 - Estudo de Casos. 131

Tabela 2 - Processo criativo. 


\section{LISTA DE ABREVIATURAS E SIGLAS}

$\begin{array}{ll}\text { ABIT } & \text { Associação Brasileira da Indústria Têxtil } \\ \text { APL } & \text { Arranjos Produtivos Locais } \\ \text { CETESB } & \text { Centro Tecnológico de Saneamento Básico } \\ \text { CMS } & \text { Control Mind Sistem } \\ \text { ISSO } & \text { International Standardization Organization } \\ \text { MG } & \text { Minas Gerais } \\ \text { PML } & \text { Produção Mais Limpa } \\ \text { RG } & \text { RIO GRANDE DO SUL } \\ \text { RGB } & \text { Red, Green e Blue (Sistema de cores aditivadas) } \\ \text { SAGE } & \text { Strategic Advisory Group on Environment } \\ \text { SC } & \text { SANTA CATARINA } \\ \text { SEBRAE } & \text { Serviço brasileiro de apoio a Micro e Pequenas Empresas } \\ \text { SENAI } & \text { Serviço Nacional da Indústria } \\ \text { SP } & \text { São Paulo } \\ \text { VMMR } & \text { Vestuário de Moda da Malharia Retilínea } \\ \text { IUAV } & \text { Università di Venezia, Curso di Design di Moda }\end{array}$





\section{SUMÁRIO}

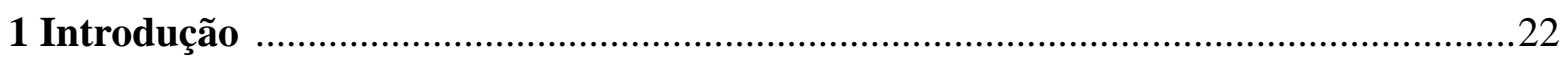

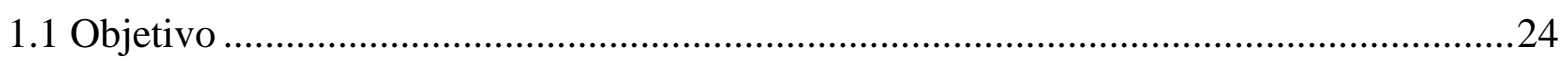

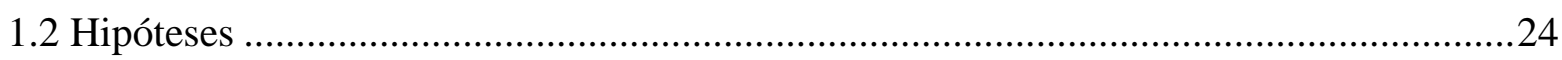

1.3 Metodologia

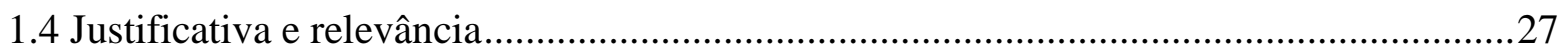

2 A cadeia de suprimentos do vestuário de moda de malharia retilínea ..........................30

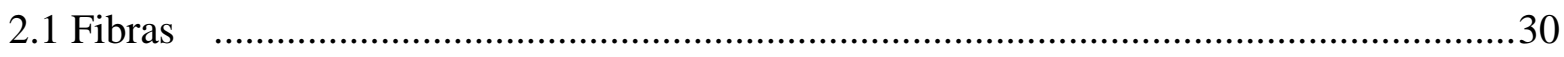

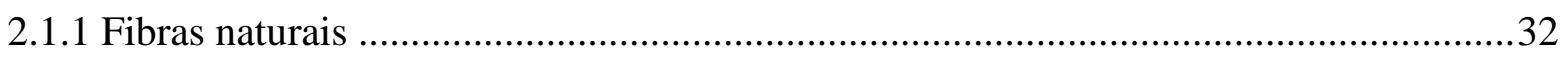

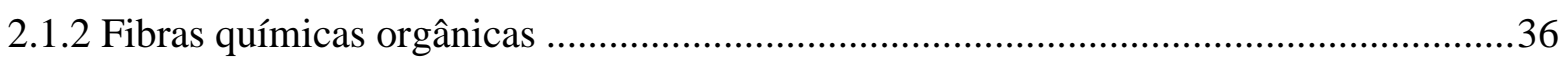

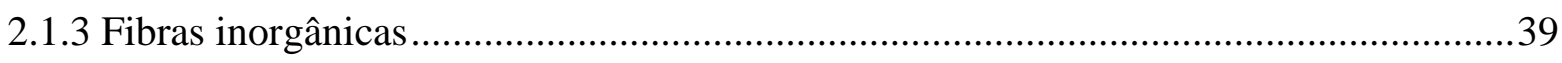

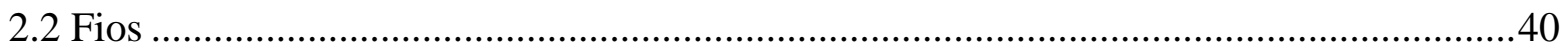

2.3 Malharia

2.3.1 Tecimentos e Pontos na Malharia Retilínea ................................................................53

2.3.2 Máquina de Malharia Retilínea Eletronicas .............................................................62

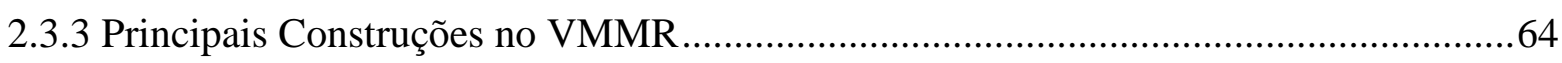

2.4 Impacto ambiental e sustentabilidade no VMMR …………………….........................68

3 Desenvolvimento de Produto de Vestuário em Moda na Malharia Retilínea ..............74

3.1 Processos de desenvolvimento de produto no VMMR ....................................................78

3.2 O Desenvolvimento de Produto e seus Processos Criativos em VMMR...........................79

3.3 Capacitação do profissional de desenvolvimento de produto de VMMR ...........................85

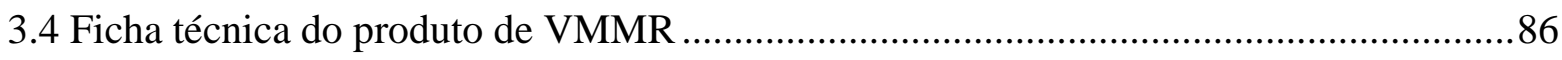

3.5 Modelagem no produto de VMMR …………………............................................90

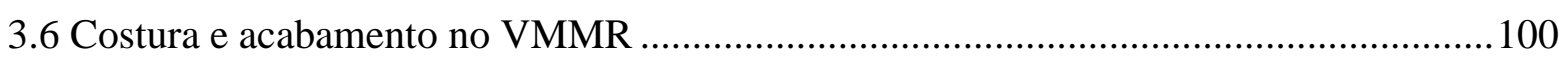

4 Moda no produto de Vestuário de Malharia Retilínea …………………………….....102

4.1 Estudos em Moda e estilistas relevantes no processo de criação de VMMR .................106 
4.1.1 Emilio Pucci

4.1.2 Família Missoni

4.1.3 Issey Miyake

5 Estudo da aplicabilidade de métodos de desenvolvimento de produto

da engenharia para o VMMR

5.1 Método MAPP-3A - Mello (2011)

5.1.1 Métodos Pugh e Money (1998)

5.1.2 Método Pahl e Beitz (1996)

5.1.3 Método Munari (2002)

5.2 Método PRODIP - SILVA, J.C, Back. N., Ogliari. A.D. (2008)

5.3 Análise dos métodos apresentados e aplicação no processo de Criação

em produto de VMMR

6 Estudo de Casos

6.1 Fabricantes de produto de VMMR no Polo Industrial do Sul de Minas Gerais

6.2 Centros de referência técnica para o Polo Industrial do Sul de Minas Gerais.

6.2.1 Fabricante de equipamentos Stoll

6.2.2 Fabricante de Equipamentos Shima

6.2.3 Escritório comercial de importação de fios Pinotti.

6.2.4 LP estilo e modelagem

$7.1 \mathrm{O}$ processo de desenvolvimento de produtos

7.2 Análise dos estudos de caso segundo o grau de estruturação e profissionalização do processo criativo e de desenvolvimento de produto

7.3 Análise do processo de desenvolvimento de produto com base no esquema radial.......155

7.4 O importante papel das soluções tecnológicas da indústria de equipamentos

8 Conclusões

8.1 Conclusões Finais 165

9 Referências 167

10 Glossário 


\section{Introdução}

Essa dissertação apresenta a pesquisa de desenvolvimento de produto da indústria do Vestuário de Moda da Malharia Retilínea (VMMR) no Polo Industrial do Sul de Minas Gerais, identificando suas características e desafios diante de um mercado cada vez mais competitivo.

O estudo sobre processos de desenvolvimento de produto foi aprofundado buscando referências de moda, de processos criativos, de alguns estilistas relevantes no VMMR, e dos constantes desenvolvimentos tecnológicos dos equipamentos e matérias primas.

Os processos de desenvolvimento de produto apresentam-se de várias formas e métodos conforme a necessidade e repertório do estilista e do sistema de trabalho dos profissionais envolvidos na criação de novos produtos. Como exemplo, podemos avançar em uma linha de biodesign onde se busca referências no estudo de processos biológicos dos seres vivos ou em estética que tem por objetivo o estudo da natureza do belo e dos fundamentos da arte.

O estudo aprofundado em referências históricas do design, engenharia, estudo do comportamento humano e manifestações artísticas são fontes de inspiração para o desenvolvimento de produto sustentável de produtos inovadores.

No fenômeno da moda, a sociedade atual atribui mais valor ao que é novo. Neste contexto, o produto de vestuário na malharia retilínea tem um alto valor no universo da moda, pois ele apresenta novidades surpreendentes, uma vez que envolve a tecnologia que avança continuamente, desenvolvendo artigos produzidos por máquinas de malharia retilíneas eletrônicas com tecnologia cada vez mais avançadas.

No Brasil do início da década de 1990, o Vestuário de Moda da Malharia Retilínea, (VMMR), tornou-se produto indispensável nas coleções de moda, principalmente por dois motivos: as tendências de moda que evocavam o efeito handmade (feito à mão, tricotado), e os investimentos em pesquisas para desenvolver fios adequados ao clima tropical. No entanto, em países de clima frio do hemisfério norte, seu sucesso sempre foi incontestável.

Na criação de um produto de Vestuário de Moda na Malharia Retilínea (VMMR) é importante a interação dos conhecimentos dos programadores dos teares eletrônicos com uma equipe multidisciplinar que engloba os conhecimentos e técnicas dos estilistas, modelistas, artistas ou artesão que desenvolvem os produtos. O modelo de fluxograma no 
desenvolvimento de produto vai depender de muitos fatores como a escolha de maquinário, processo de fabricação e acabamentos.

A indústria da moda atualiza-se a cada dia e trabalha com uma nova realidade, que hoje leva em conta a responsabilidade socioambiental. Isso significa introduzir nos processos, de toda cadeia produtivas do setor, ações concretas, visando adequar a produção aos princípios do desenvolvimento sustentável. E não pode ser diferente porque a natureza está integrada a vida humana e vice-versa.

Faz-se então, necessário ter consciência dos riscos ambientais provocados pelos resíduos e materiais poluentes que integram o processo de fabricação do produto de VMMR. Os custos marginais de descarte nem sempre são contabilizados e a malharia tem um prejuízo não identificado. Dependendo da escolha dos fios e dos padrões, o descarte pode ficar maior, sendo que é muito comum ser maior em peças mais elaboradas. Na cidade de Monte Sião há empresas que fazem a coleta de descartes e seu reaproveitamento, mas ainda são raras as empresas que seguem esse caminho.

A autora, como profissional atuante na área de produto do VMMR há mais de 30 anos, manifesta um real interesse em contribuir com uma ampla pesquisa sobre os processos de desenvolvimento na concepção do produto, além de ter colecionado em sua experiência uma vasta gama de conhecimentos obtidos empiricamente, que a permitem a formulação de hipóteses consistentes.

Durante a experiência como consultora de indústrias do polo do Sul de Minas Gerais nos últimos oito anos, a autora observou, por um lado, a dificuldade das empresas em se posicionar contra a ameaça da importação e, por outro lado, a dificuldade na interação dos profissionais envolvidos nos processos de desenvolvimento, criação e produção do VMMR.

A partir da observação do cotidiano dessas empresas e com o interesse de gerar conhecimento disponível para amplificar suas chances diante de um mercado cada vez mais competitivo, foi iniciada a pesquisa com uma varredura a um referencial teórico, exposto a partir do segundo capítulo deste material, no qual foram estudadas as diversas etapas de desenvolvimento de produto na cadeia têxtil-vestuário, o histórico desse setor, e os processos de criação. Neste capítulo apresenta-se o desenvolvimento de produto, a capacitação do profissional de desenvolvimento de produto e suas fases de produção: tecimento, modelagem, montagem com costura e acabamento das peças de vestuário. Também foram realizadas 
pesquisas sobre modelos de engenharia de desenvolvimento de produto, e analisadas as possibilidades de aplicação desse referencial para o universo do VMMR.

\subsection{Objetivo}

O objetivo geral da dissertação presente é pesquisar o desenvolvimento de produto de Vestuário de Moda da Malharia Retilínea (VMMR), bem como seus processos criativos e sua preparação para o processo produtivo.

Os objetivos específicos dessa dissertação são:

1 Pesquisar o processo de desenvolvimento do produto de moda de vestuário em malharia retilínea: cadeia de suprimentos, programação e tecnologias (equipamentos e softwares), e sustentabilidade.

2 Verificar métodos empregados no processo de desenvolvimento de produto na engenharia que contribuam para o desenvolvimento de novos produtos nas empresas de VMMR.

3 Pesquisar a capacitação e a interação dos profissionais que são envolvidos no desenvolvimento de produto de VMMR, em especial o estilista, o programador e o modelista.

4 Pesquisar o histórico do produto de VMMR no aspecto de moda, principais estilistas e seus processos de desenvolvimento de produto.

\subsection{Hipóteses}

As hipóteses dessa dissertação são:

A. O processo de desenvolvimento do VMMR é dificultado pela falta de conhecimento e comunicação entre os técnicos e estilistas.

B. Melhores conhecimentos de estilo, modelagem e programação de máquina poderão melhorar os processos de desenvolvimento de produto e consequentemente gerar inovação no produto de VMMR. 


\subsection{Metodologia}

Com o intuito de promover essa visão holística, a autora optou pelo método de Levantamento Bibliográfico, na busca de referenciais teóricos que formem a estrutura e a base teórica para a formulação dos questionários abertos aplicados a estudos de casos.

Dentre possíveis métodos de pesquisa científica, este estudo precisa considerar a natureza de um cenário empírico e pouco estudado como o campo do VMMR. Segundo Bauer (2000, p. 26):

\footnotetext{
"O que é necessário é uma visão mais holística do processo de pesquisa social, para que ele possa incluir a definição e a revisão de um problema, sua teorização, a coleta de dados, a análise dos dados e a apresentação dos resultados. Necessitamos de uma noção mais clara das vantagens e desvantagens funcionais das diferentes correntes de método, e dos diferentes métodos dentro de uma corrente".
}

Segundo Almeida (2012, p. 19), “entende-se por método o conjunto de processos que o espírito humano deve empregar na investigação e na demonstração da verdade”.

Segundo Almeida (2012, p. 68), “uma pré-pesquisa com questionário em aberto é um levantamento preliminar sem a pretensão de esgotar a bibliografia disponível sobre o tema, mas possibilita estabelecer os parâmetros da abordagem".

Porém, considerando que, na pré-pesquisa, foi identificada a pequena disponibilidade de material bibliográfico científico sobre o VMMR, o que motivou sua complementação através de uma investigação documental em empresas industriais e fabricantes de equipamento, e de uma pesquisa exploratória em livros, revistas, internet, catálogos e outros mais.

Nesta etapa, também foram incluídas informações coletadas em visitas a feiras nacionais e internacionais com foco em malharia de tricô, seu processo criativo e suas inspirações, como a ITMA e a PITTI FILATI.

A pesquisa exploratória é realizada em áreas na qual há pouco conhecimento acumulado e sistematizado (Almeida, 2012, p. 72).

Os Estudos de Casos foram realizados através da aplicação de questionário com perguntas em aberto com entrevistas narrativas. $\mathrm{O}$ foco das entrevistas foi identificar etapas das pesquisas em desenvolvimento de produto, o processo criativo do estilista e sua interação com os modelistas e programadores de máquinas retilíneas. 
O questionário foi apoiado com uma proposta de método de desenvolvimento de produto em etapas criado a partir da pesquisa bibliográfica e da pré-pesquisa de campo focando principalmente o processo de criação de produto de VMMR e foram divididos em duas direções:

- Empresas fabricantes de produto do VMMR - foram realizados estudos em dez empresas que produzem peças de malharia retilínea, explorando as etapas do desenvolvimento de produto e seus processos criativos nas escolhas de matéria prima, modelagem, tecnologia de máquinas e posicionamentos de mercado.

- Referências técnicas no Polo Industrial de VMMR do Sul de Minas - foram realizadas quatro entrevistas de referências técnicas para a região, sendo as duas principais fabricantes de máquinas retilíneas eletrônicas, um escritório comercial fornecedor de matéria prima e uma consultoria de estilo e modelagem.

Analisar os dados levantados durante as entrevistas conduz a novas questões sobre o saber destes profissionais e um possível método de treinamento, a fim de aumentar a qualidade do desenvolvimento de produto e o valor agregado de comercialização, impulsionando empresas para enfrentar os desafios de mercado.

A base desse estudo é a pesquisa qualitativa, sobre a qual Bauer (2000, p. 22) define:

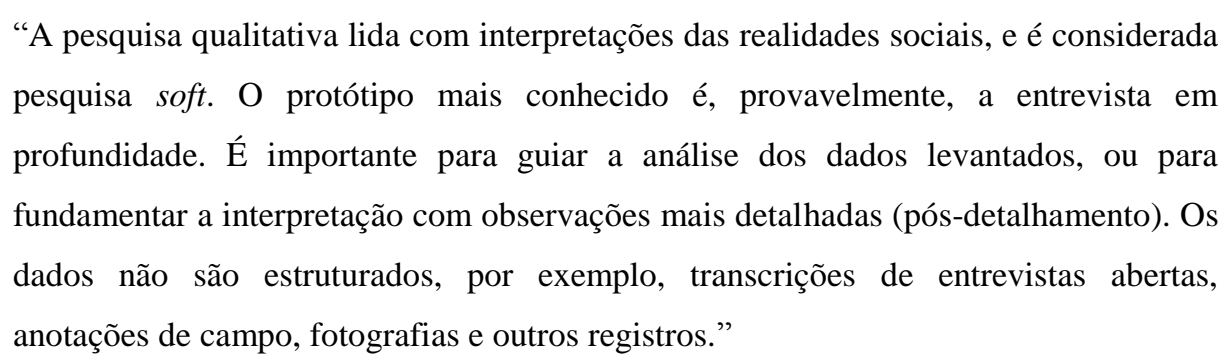

Ainda, segundo o autor, os passos para uma pesquisa qualitativa são:

- Preparação do tópico guia;

- Seleção entre o método individual e grupal;

- Delineamento da estratégia/abordagem;

- Realização das entrevistas;

- Transcrição das entrevistas;

- Análise das informações coletadas. 


\subsection{Justificativa e relevância}

O Brasil conta com quase 108 mil empresas de Vestuário, das quais aproximadamente 13 mil são de malharia retilínea, o que equivale a $12 \%$ do parque fabril (SEBRAE, 2012).

O Ministério do Desenvolvimento de Indústria e Comércio Exterior, em artigo publicado em 2011, destaca a relevância da cadeia têxtil-vestuário:

\footnotetext{
"O setor têxtil e de confecções é relevante para a economia brasileira, uma vez que se trata do segundo maior gerador do primeiro emprego e do segundo maior empregador da indústria de transformação - em 2010 foram registrados 1,7 milhões de empregados, dos quais o montante de $75 \%$ é constituído por mão de obra feminina. Ademais, representa $3,5 \%$ do PIB total brasileiro e possui grande volume de produção, com confecções de 9,8 bilhões de peças".
}

Com relação ao segmento de malharia retilínea, segundo o Panorama do Mercado de Malharia Retilínea, publicado em 2011 pela ABIT (Associação Brasileira da Indústria Têxtil), o Brasil conta com 1.797 mil unidades produtivas com porte industrial e em 2010 a produção de malharia retilínea alcançou 193 milhões de peças, cresceu em produção 3,4\% em volume e chegou a 214 milhões de peças no ano, gerando 27.000 empregos; com valores de produção de US\$ 2,3 bilhões.

Godart (2010, p. 14) trata da relevância da Moda:

"Além de ser uma importante atividade econômica, a moda representa um objeto social singular no cruzamento entre as artes e a indústria. Na qualidade de indústria, a moda, portanto, é caracterizada por uma dualidade fundamental, posto que é ao mesmo tempo uma atividade econômica e uma atividade artística".

O principal problema para as empresas nacionais atualmente é a concorrência desleal dos produtos chineses, que entram no Brasil com preços de até $60 \%$ mais baixos. Segundo o supervisor da área internacional da ABIT, Renato Smirne Jardim, "a indústria têxtil no Brasil sempre foi dirigida ao mercado interno. O mercado doméstico responde por $92 \%$ do faturamento. Qualquer interferência neste mercado é preocupante” (DINI, 2006).

No Panorama do Mercado de Malharia Retilínea, publicado pela ABIT em 2011, estima-se que aproximadamente $10 \%$ dos empregos foram supridos por artigos importados em 2010.

Rech (2002, p. 220) considera que, 
"para competir com os produtos chineses, o segmento de malharia retilínea aposta em
novos mercados, novas matérias primas e na modernização de maquinários. Torna-se
evidente a necessidade de produzir não apenas peças com preços competitivos, mas
também mais elaboradas, belas e que possam ser vendidas o ano inteiro, nas diversas
estações."

A malharia retilínea permite servir-se de muitos recursos criativos no desenvolvimento de produto. Esses recursos se multiplicam com base em testes empíricos de criação de produto e com as novas tecnologias desenvolvidas na construção da malha, principalmente pelas máquinas eletrônicas. Estudar estes recursos tecnológicos de uma forma persistente é um fator importante para o profissional que quer evoluir no processo de desenvolvimento de produto do VMMR.

Uma máquina retilínea eletrônica computadorizada nova custa aproximadamente $\mathrm{R} \$$ 300.000,00 e leva aproximadamente 40 minutos para tecer uma peça inteira de dificuldade média. As fábricas, com esse equipamento, costumam trabalhar em três turnos para amortizar mais rapidamente o alto custo da máquina.

O valor agregado da peça produzida pela retilínea é alto e diferente do valor agregado de uma peça de malha circular ou tecido plano. As máquinas que produzem malharia retilínea tem um alto componente tecnológico resultado de muita pesquisa e trabalho para alto desempenho em qualidade e tempo.

Esse cenário atual de desafio para a indústria nacional diante da questão do valor agregado em comparação a produtos importados amplifica a relevância da discussão do tema dos processos de desenvolvimento de produto na Indústria de VMMR, tendo em vista também a existência de polos importantes de produção desse artigo no Brasil, no Sul de Minas Gerais e em Caxias do Sul.

O segundo polo importante é o denominado Circuito das Malhas. Localiza-se em parte no Sul do Estado de Minas Gerais, consideradas as cidades de Jacutinga e Monte Sião, Borda da Mata, e Inconfidentes, e Norte do Estado de São Paulo, cidades de Amparo, Serra Negra, Socorro e Águas de Lindóia. A Fenart, feira de artigos de malha, atrai muitos turistas para a região de Monte Sião. Segundo estudo de Fabio Sevegnani, UNIP, (2008) "Existem aproximadamente 5.000 pequenas e micro empresas, grande parte na informalidade". Grande parte das empresas da região continua na informalidade, pois são fornecedoras de mão de obra para empresas mais estruturadas. 
Segundo o SEBRAE de Minas Gerais em 2012 foi realizado um estudo de análise de atratividade de APLs no setor de confecção em Monte Sião e foi apresentado na figura abaixo o mapa de polos de malharia retilínea no Brasil:

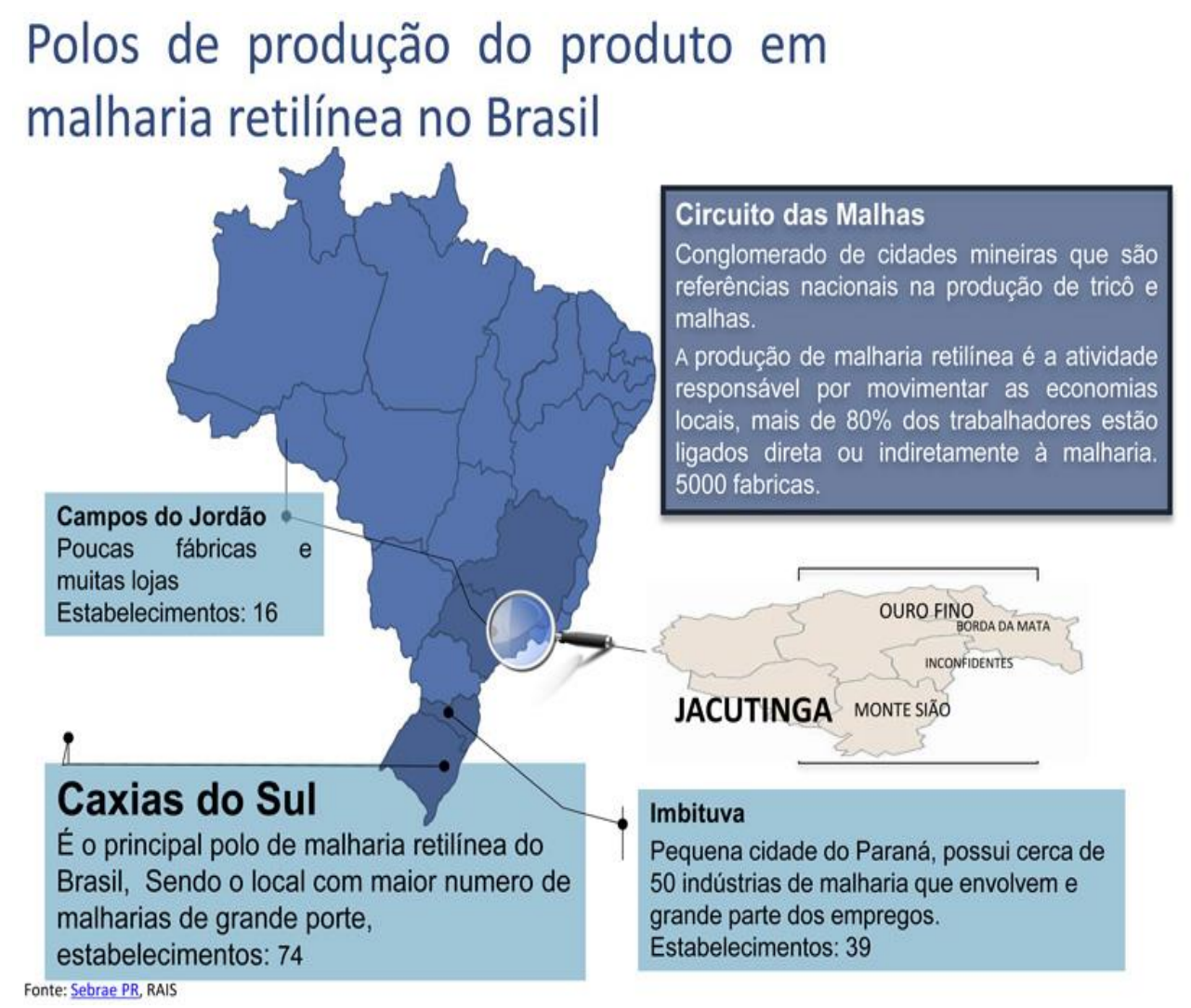

Figura 1 - Polos de Malharia Retilínea no Brasil. Fonte: SEBRAE, 2012.

Neste estudo do SEBRAE, 2012 foi constatada que para as pequenas empresas, que são a grande maioria das empresas da região, competir por preço não é uma alternativa sustentável, uma vez que concorrem com empresas maiores, que ganham em escala e com produtos importados principalmente asiáticos; "O caminho mais natural para diferenciação das peças de malharia passa pela criação de modelos. Entretanto, as empresas do setor encontram muitas dificuldades em captar profissionais da área e entender as tendências de consumo".

Afirma o SEBRAE, 2012 "Outro ponto importante é a necessidade de formação de marcas. Por mais que os produtos possuam valor agregado e sejam orientados a públicos específicos, o posicionamento da marca é decisivo para a alavancagem das vendas". E conclui "O estudo detectou que existe uma saturação do mercado de malharias e falta de preparo muitos malharistas na gestão de uma cadeia completa. Para contornar isso e suprir certas carências da cadeia produtiva, entende-se que a especialização dos atores é uma alternativa". 


\section{A cadeia de suprimentos do vestuário de moda de malharia retilínea}

A cadeia de suprimentos do produto do VMMR inicia com a produção das fibras que compõem os fios através do processo de fiação. Os fios são entrelaçados para formar malhas ou tecidos planos, conforme a construção têxtil. Tecidos planos, malhas circulares e malhas retilíneas possuem características distintas, de forma que o processo de tecelagem influencia profundamente o resultado. As malhas podem ainda ser circulares ou retilíneas, conforme o processo de tecelagem.

Os tecidos são superfícies vivas compostas de fios ou também de filamentos em que o desenvolvimento obedece a várias técnicas onde o resultado é o que carregamos em nosso corpo, um produto que utilizamos para cobrirmo-nos e proteger-nos (CONTI, 2014, p. 26, tradução nossa).

No caso da malharia retilínea, as características dos diferentes visuais do produto de VMMR são desenvolvidas a partir dos fios que interferem fortemente no design do produto. Profissionais de design de produto no VMMR desenvolvem fios específicos junto a uma equipe de engenheiros químicos e de produção para atender as constantes mudanças propostas pela moda, a cada estação, dentro da evolução tecnológica.

\subsection{Fibras}

As fibras têxteis podem se dividir em naturais e químicas. Os fios com fibras naturais se dividem em: vegetais, animais provenientes da lã e minerais. Os fios de fibras químicas são divididos em: orgânicos artificiais, orgânicos sintéticos e inorgânicos (TEXTILE VIVANT, 2014, p. 66).

Existem fibras de filamento contínuo (mais longas) e fibras de filamento descontínuo. As fibras naturais são descontínuas e muito mais curtas, formadas por inúmeros pedaços torcidos e fiados para fazer um fio. O único filamento contínuo de fibra natural é a seda.

As fibras químicas são divididas em sintéticas e artificiais. As sintéticas são as produzidas em laboratório: poliamida, poliéster, poliuretano, acrílico e polipropileno. As artificiais são derivadas da celulose como o rayon, viscose e triacetato. 
A figura abaixo apresenta a porcentagem da produção mundial do ano de 2011 de cada fibra:

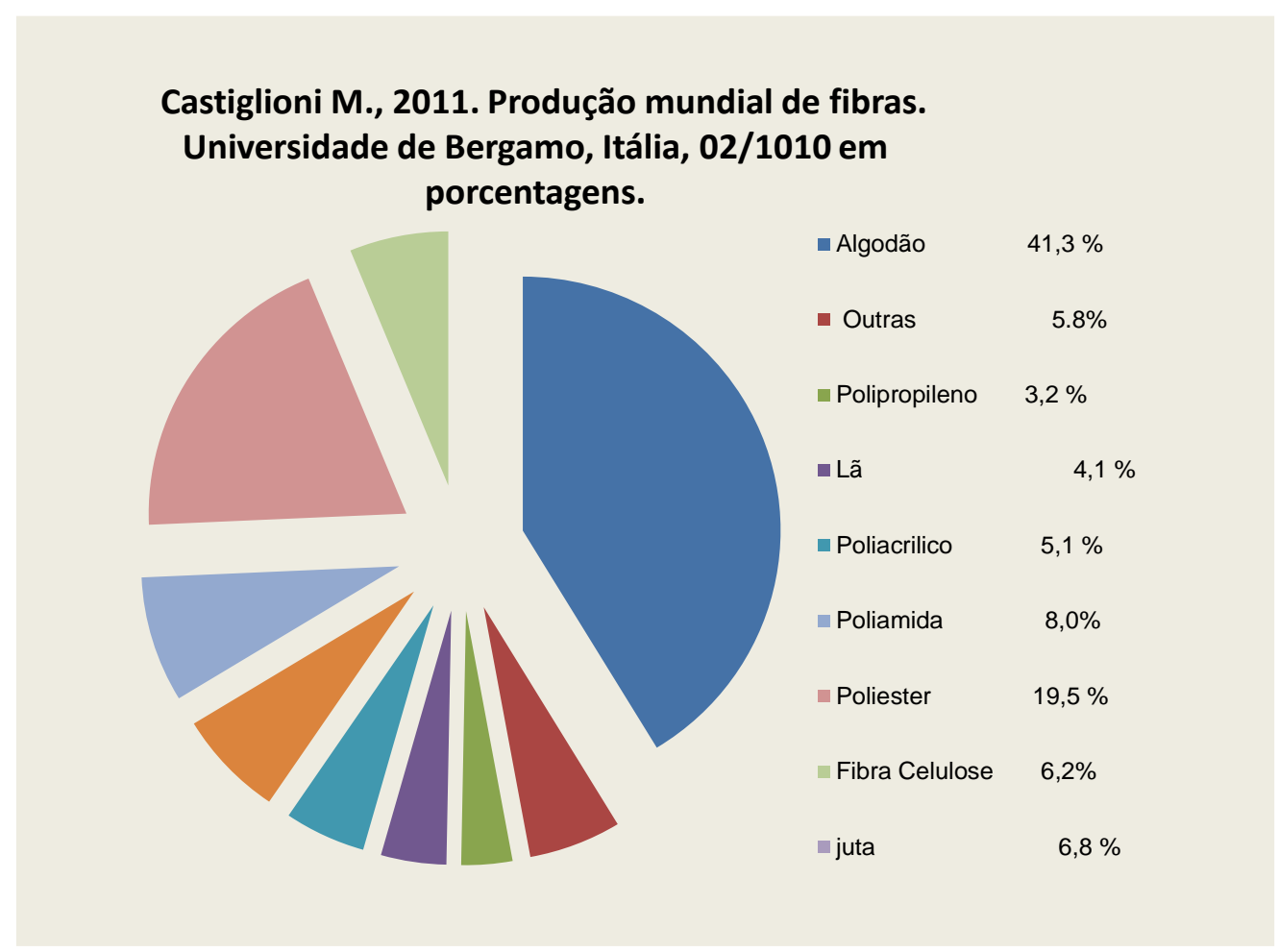

Figura 2 - Produção mundial de fibras (Castiglione M., 2010).

As fibras sintéticas são produzidas em forma de filamentos contínuos, mas muitas vezes cortadas em comprimentos de fibras descontínuas mais curtas antes de serem fiadas, a fim de obter determinadas propriedades físicas (SISSONS, 2010, p. 16).

Segundo Jones (2011, p. 138)

"um estilista perito é capaz de distinguir as fibras fundamentais pelo toque e pelo aspecto visual. Hoje existem muitas mesclas e versões patenteadas de fibras artificiais. A qualidade do conjunto de fibras têxteis que compõe a matéria prima, o método de trabalho e o diâmetro do fio determinam as características do tecido".

A partir da Segunda Guerra Mundial, muitos materiais que foram desenvolvidos para tarefas militares foram migrando para roupas do dia a dia. As fibras de carbono e de vidro foram utilizadas em razão de sua alta resistência e leveza. O nylon e o poliéster ganharam destaque por serem confortáveis, apesar de sua respiração difícil, e substituíram as fibras naturais, escassas naquele período (AVELAR, 2009 p. 141)

Ainda na década de 1970, o estilo esportivo foi intensamente disseminado. A marca Dupont melhorou a fibra sintética conhecida como elastano, a marca criada em 1958 pela 
Dupont para o elastano foi denominada Lycra. Esta fibra é importante, pois possibilita a criação de diferentes formas e relevos nos tecido de malha. Pela sua elasticidade, com propriedades mecânicas de retenção e soltura dos pontos, produz um efeito de franzidos e texturas com diferentes espessuras de fios.

As fibras mais utilizadas no produto de VMMR são o algodão, lã natural, acetato, modal, elastano, cashmere, viscose, acrílico e a poliamida. Fibras como o cashmere e o mohair são fibras naturais nobres que são utilizadas em alguns artigos de luxo. A tendência de moda mais sofisticada e com qualidade, utiliza as fibras mais nobres como as naturais ou com mesclas de naturais com outras fibras.

Porém, a distinção entre as fibras naturais e as artificiais está cada vez menos nítida, visto que muitas fibras naturais, como o algodão, a lã e o linho, são regularmente submetidas a tratamentos químicos. O desenvolvimento de fibras manufaturadas e de seus processos de texturização inspirou vantagens para a indústria de confecção de malhas.

Devido ao seu baixo custo e as características de praticidade e visual, a fibra mais usada no produto de VMMR é o acrílico, provavelmente pela sua relação de custo e benefício. A fibra acrílica pode ser utilizada pura ou com diversos tipos de beneficiamentos e tinturas no que resulta em um fio com toque macio e conforto térmico.

Além das propriedades visuais, amplamente desenvolvidas, as fiações estão cada vez mais voltadas para soluções tecnológicas de nanotecnologia com propriedades de tratamento. Recentemente, a Rhodia lançou uma tecnologia denominada "Emana", que tem a característica de permitir que o calor do corpo humano seja devolvido sob a forma de raios infravermelhos longos. Esses raios penetram na pele e interagem com o corpo, estimulando a microcirculação sanguínea e o metabolismo celular. Os benefícios são: aumento da elasticidade da pele, redução dos sinais de celulite, equilíbrio térmico, redução de fadiga muscular, entre outros benefícios (WORLD FASHION, ed. 143, 2013, p. 15).

Atualmente nos países mais desenvolvidos são valorizados na tendência da moda os fios de fibra natural. Os fios considerados mais nobres são provenientes de fibras naturais como as lãs e a seda, e de fibras vegetais como o algodão e o linho.

\subsubsection{Fibras naturais}

As fibras naturais se dividem em vegetais e animais. 
As fibras naturais vegetais são provenientes das plantas cultivadas: como o algodão, a juta, o linho, o rami, o bambu e o cânhamo. As fibras naturais vegetais são compostas por celulose natural; por isso, também são chamadas de fibras celulósicas naturais. São derivadas de uma grande variedade de sementes, dos caules e das folhas das plantas. Alguns exemplos: algodão, linho, juta, coco, sisal, cânhamo, bambu, rami entre outras (SISSONS, 2010).

Todas essas fibras possuem composição química muito semelhante; porém, suas propriedades físicas, mecânicas e aparência diferem muito umas das outras. Tal variação de característica pode ser notada principalmente nos tecidos manufaturados por diferentes fibras celulósicas, como por exemplo, a maciez de um tecido de algodão, contra o toque seco do tecido de linho.

De todas as fibras vegetais, algodão e o linho são as mais importantes:

- Algodão (CO) - Fibra natural das plantas do gênero "Gossypium”, utilizadas na fabricação de fios e tecidos. O algodão com mais qualidade é o do Egito, que tem uma cor amanteigada e a fibra comprida. É muito utilizado para confeccionar peças de vestuário de verão, principalmente na malharia circular. No Brasil é uma das fibras mais consumidas na malharia retilínea. Muitas empresas tecem as malhas sem tingimento para depois beneficiar com vários processos diferenciados de coloração dando um estilo de moda. É usado pelo seu conforto "tecno" com alto grau de absorção em roupas íntimas, camisetas, roupa interior, camisas desportivas, etc. $\mathrm{O}$ algodão passa por um processo de mercerização para ser tecido mais uniformemente. Proporciona um alto conforto ao contato direto com a pele (SISSONS, 2010)

- Linho (LI) - Fio proveniente de fibras longas e do caule da planta do linho; é ideal para a confecção de roupas de verão. Esse fio é forte, tem pouca elasticidade e, em geral, é misturado com outras fibras, como algodão, para ficar mais fácil de trabalhar. De todos os tecidos, o mais ecológico é o linho, uma vez que seu cultivo quase não utiliza fertilizante químico; também não provoca desperdícios, pois a palha que sai da flor do linho serve para a fabricação de aglomerado, e a semente da planta se transforma em óleo de linhaça. O linho é 100\% biodegradável, antibacteriano, antifugicida, de baixa elasticidade. Não deforma facilmente, não causa irritações na pele nem alergias e é altamente resistente. O custo da produção do linho é alto. O fio é produzido a partir da fibra, que é importada de países 
europeus como Bélgica e França. Para deixar esse material comercialmente viável, ele tem sido misturado com fibras como algodão, seda e viscose. (SISSONS, 2010)

As fibras naturais de origem animal são obtidas de pelos ou de secreções de animais, e são conhecidas como fibras proteicas, por possuírem na sua estrutura química básica a composição de aminoácidos.

Todas as fibras proteicas contêm os elementos carbono, hidrogênio, oxigênio e nitrogênio em sua composição. Em cada fibra proteica estes elementos são combinados em diferentes quantidades e em diferentes formas moleculares. Como resultado, as propriedades de cada fibra tendem a serem consequentemente muito diferentes umas das outras, conferindo aos tecidos diversas propriedades, cores, texturas, etc.

O tecido feito de pelo serve como isolante térmico, não esquenta e mantém a temperatura do corpo em média 5 a 8 graus mais baixa em comparação com tecidos sintéticos quando expostos ao sol. O fio produzido de pelo é também chamado lã, como lã produzida por pelo de lhama, alpaca, vicunha, camelo, coelho (angorá) e outros mais. O processo inclui: tosa do animal, lavagem do pelo (para tirar impurezas), carda, fiação, tingimento e rebobinamento (SISSONS, 2010).

A lã de ovelha é um dos tipos mais comuns de fios utilizados na confecção de malhas retilíneas de boa qualidade, pois possui elasticidade natural, e facilita a confecção de artigos de design diferenciado. Ela pode ser desenvolvida em diversas espessuras de fios, dependendo da forma como é fiada, e sua qualidade pode variar de acordo com o tipo de ovelha. (SISSONS, 2010, p. 18).

A seguir a definição das principais fibras naturais de origem animal (TEXTILEVIVANT, 2014):

- Lã (WO) - O tecido de lã obtém-se do pelo da ovelha. As suas fibras são elásticas, de cor predominantemente branca, com brilho natural variável. A propriedade elevada de proteção térmica, elasticidade, resistência ao uso e a chama rendem a lã uma ótima capacidade de proteção contra o frio. Existem vários tipos de lã de carneiro, como, por exemplo, a Shetland que são tosadas de carneiros recém-desmamados e resultam em fios muito leves e macios. Essa fibra tem um valor elevado e, por isso tem sido substituída pela fibra acrílica. Existem diversos tipos de lã. A lã Merino é de altíssima qualidade e provém de raça de 
ovelhas do mesmo nome criada na Austrália, também é usada em produtos de alta qualidade geralmente misturados com outras fibras. A lã Merino também tem a variedade "extra", tosada de ovelhas com menos de oito meses de idade, é ainda mais valiosa e especial.

- Angorá (WA) - Lã que vem do coelho angorá é um fio suave e macio. É normalmente utilizado em misturas com lã de ovelha para ter um fio com maior resistência.

- Cashmere (WM) - Lã suave de pelo longo obtida de uma raça de cabra de origem asiática. A lã cashmere tem um toque muito agradável e um aspecto refinado e é empregada principalmente para artigos de luxo. Esta lã tem a propriedade de reter o calor, por esta razão é muito utilizada em lugares de clima frio. O fio proveniente desta fibra tem espessura fina e leve, consequentemente tece produtos de malhas muito leve que protegem a baixas temperaturas.

- Camelo (WK) - Lã de camelo é uma fibra robusta, quente e pesada, utilizada em artigos de luxo. O Camelo perde o fio naturalmente com a mudança de estação.

- Alpaca (WP) - Tecido feito de lã de fibras de alpaca. Esta fibra é o pelo de um animal com o mesmo nome ou a lhama da América do Sul. A fibra é comprida, leve, sedosa, e possui grande poder de isolamento térmico. A cor natural é o castanho claro. Usa-se geralmente em mistura com lã de ovelha.

- Vicunha (WN) - Pelo finíssimo e muito resistente proveniente da raça de Lhama Vicunha da América do Sul.

- Seda (S) - A seda é proveniente do casulo da largata de mariposa. Os casulos são removidos com os bichos dentro, postos para secar e depois cozidos. O cozimento mata a larva e amolece o casulo que é feito de filamentos da saliva da lagarta. Vários filamentos são unidos por uma substância chamada sericina, formam os fios de seda. É uma das fibras têxteis mais antigas, começou a ser utilizada na China, zona de Shandong. O aspecto irregular desta fibra é muito simples podendo ser confundida com fios de fibras sintéticas. Existem muitos tipos de seda, a mais comercializada é do bicho da seda da amoreira. Na malharia a seda costuma participar na composição do fio com uma porcentagem muito baixa. Ela é utilizada para dar brilho, resistência e maciez nos produtos de alta qualidade. 
Atualmente, o Brasil é o quarto produtor mundial de seda. No Paraná, o vale da seda produz o fio de seda com excelente qualidade.

\subsubsection{Fibras químicas orgânicas}

As fibras químicas são divididas em orgânicas sintéticas, orgânicas artificiais e as inorgânicas. As fibras químicas orgânicas são produzidas em laboratório pelo homem. As químicas artificiais são derivadas da celulose como o rayon, viscose e triacetato entre outras.

Segundo Lopes, (2013, pg. 20) "As fibras artificiais são produzidas a partir da celulose, uma substância fibrosa encontrada na polpa da madeira ou no línter do algodão, razão pela qual também são chamadas de fibras celulósicas.”

Segundo Romero ET al. (1995), a primeira fonte de celulose purificada, foi o línter de algodão, que “é a fibra curta restante na semente do algodão após o descaroçamento". Os fios de fibras químicas artificiais provêm de polímeros naturais produzidos pelo homem (também chamadas de regeneradas), que tem como base a celulose. São atualmente as mais utilizadas pela malharia em geral e seus custos resultam em peças com um valor muito menor que as naturais. A seguir as principais fibras químicas (TEXTILEVIVANT, 2014):

- Acetato (CA) - Também chamado de rayon, a mais conhecida das fibras artificiais regeneradas. Normalmente é caracterizada por seu brilho e costuma ser usada como um substituto da seda. Os seus flocos são derivados da reação química do anidrido acético com a polpa de madeira. A fibra bruta é derivada da transformação física dos flocos de acetato de celulose, em que este é dissolvido em acetona e, então, dilatado em fibra bruta. As fibras artificiais de rayon de acetato costumam ser obtidas mediante um processo químico através do qual se dissolvem desperdícios de algodão num banho de ácido acético. $\mathrm{O}$ acetato de celulose é usado na indústria têxtil como tecidos especiais (mantas, forros e fios de seda). Patenteado como seda artificial em 1921 (JONES, 2011, p. 140).

- Viscose (CV) - A viscose é uma fibra artificial que se obtém a partir da pasta de celulose de certos vegetais, especialmente da madeira. Os fios da viscose são mais brilhantes ou menos brilhantes, flexíveis e suaves, imunes ao bolor e à traça. O tecido de viscose utiliza-se em malhas e tecidos para lençóis, toalhas de mesa, tecidos industriais e roupa desportiva (SISSONS, 2010). 
- Lyocel (CLY) - É uma fibra artificial celulósica regenerada produzida da celulose da madeira. Seu processo de obtenção é parecido com o da viscose. É a mais resistente das fibras celulósicas, tanto seca como úmida diferente da viscose, que quando úmida, perde de 40 a $60 \%$ de sua resistência. Provém da polpa de eucalipto e passa por um tratamento químico de fiação em solvente orgânico, a fim de promover um toque macio e suave, sem agredir a pele. $\mathrm{O}$ Lyocel foi inventado por Courtauld em 1988 e recebeu o nome de marca tencel. O processo de produção é pouco poluente, os solventes utilizados são atóxicos e recicláveis. Estes materiais são capazes de alto desempenho de elasticidade e misturas de absorção. Eles também são usados como revestimentos no setor pela saúde e tem habilidades de isolamento (TEXTILEVIVANT, 2014).

- Modal (MD) - Fibra artificial celulósica regenerada, produzida da celulose da madeira. Seu processo de obtenção é parecido com o da viscose, mas com algumas diferenças em concentração de substâncias e na maturação. Pode ser produzida em filamento contínuo ou fibra cortada. Muito resistente, devido às suas estruturas. Possui toque macio que dá a sensação de "pele sobre pele", mesmo após diversas lavagens. Absorve $50 \%$ a mais de umidade que o algodão e de forma mais rápida. Possui boa capacidade de retenção de corantes, de forma rápida, profunda e permanente. A superfície lisa da fibra é responsável pelo brilho sedoso dos artigos de modal.

As fibras químicas sintéticas são originárias de polímeros petroquímicos, como acrílico, poliamida, poliéster, polipropileno, elastano, poliuretano entre outras. Fibras sintéticas são produzidas pelo homem a partir de produtos químicos da indústria petroquímica. As fibras químicas sintéticas são obtidas a partir de derivados do petróleo; tiveram sua produção comercial iniciada na década de 1930, também nos Estados Unidos, com o nylon (quimicamente, uma poliamida). As principais fibras sintéticas produzidas pela indústria petroquímica são o poliacrílico, o poliéster, o elastano (lycra), o polipropileno e a poliamida. A segunda geração de sintéticos responde pela invenção de rayon, lycra e viscose no inicio das décadas do século $\mathrm{XX}$, incluindo fibras de fino poliéster, poliamida e viscose, que tornou uma incrível base de matéria-prima e um marco no desenvolvimento de produto.

A viscose e o rayon são amplamente usados na composição dos fios para malharia retilínea, pois têm propriedades que oferecem resistência, elasticidade, absorção de água entre 
outros atributos. O acetato e a viscose são da família do rayon e podem derreter sob ferro quente. O fio proveniente dessa fibra tem uma aparência leve e sedosa que muitas vezes se assemelha às características nobres da seda (TEXTILEVIVANT, 2014). As principais fibras são:

- Acrílico (PAC) - Fibra sintética muito parecida com a de lã no aspecto e no tato; é a versão sintética derivada da acrilonite, desenvolvida pela Dupond nos anos de 1940. É uma fibra leve, econômica e de fácil manutenção. Resistentes à luz e às alterações de tempo e não é afetada pela umidade; retêm o calor e pode submeter-se ao vincado permanente. Utiliza-se principalmente para confeccionar peças de agasalho em substituição à lã natural com sucesso no VMMR, pois seu custo é baixo em relação à fibra de lã. Essa fibra é resistente a lavagens a máquina, tem cores firmes e brilhantes, durável e antialérgica. Começou a ser difundida no Brasil em 1968 na fabricação de casacos, blusas, roupas infantis e de bebê. É usada na maioria dos artigos de vestuário de Malharia Retilínea (JONES, 2011, p. 140).

- Poliéster (PES) - Fibra sintética química que é fabricada tanto em filamento contínuo, para a confecção de tecidos lisos, como em filamento cortado, para confeccionar tecidos dos mais variados aspectos, como a lã, a seda, o algodão, etc. O poliéster é muito resistente, não amassa, é fácil de lavar e seca rapidamente. É uma fibra com ampla utilização no vestuário de malharia retilínea e sua grande vantagem é o baixo custo. O fio é usado principalmente nas linhas de costura, em acabamentos, em misturas para dar mais resistência e elasticidade, em mantas, não tecidos e muitas outras aplicações. Com os tecidos fabricam-se cordas, tendas de campismo, saias plissadas, gravatas, blusas e artigos para decoração (FOGG, 2010).

- Poliamida (PA) - Conhecida comercialmente por nylon tem propriedades de resistência cerca de três a cinco vezes superiores à dos fios de algodão. É a primeira fibra sintética a ser fabricada. Obtém-se por síntese química dos derivados do petróleo. Os filamentos costumam ser lisos ou um pouco ondulados e a fibra curta e com grande variedade de grossuras. A propriedade mais importante nos tecidos de poliamida é a resistência à fricção e à tração, também não costumam deformar-se e são imunes à umidade e à ação dos ácidos diluídos, bolores, fungos, etc. Secam rapidamente, porém, dificultam a transpiração e podem causar incômodo ao usuário. Utiliza-se na elaboração de artigos que 
necessitem da máxima resistência com o mínimo de grossura do fio. $\mathrm{O}$ fio de poliamida associado ao elastano é utilizado em roupas íntimas de banho e esportivas (FOGG, 2010).

- Elastano (PUE) - Fibra derivada do poliuretano, com ótimas propriedades elásticas. Também chamado Lycra, poliuretano ou spandex. O fio desta fibra tem um alto custo e é utilizado na malharia retilínea em pequenas porcentagens, misturados a outras fibras na proporção de $0,2 \%$ a $0,10 \%$. A marca Dupont deu o nome de Lycra para a fibra de elastano. O fio de elastano é muito fino e é utilizado em torno de 5 a $10 \%$ misturados com outros fios sintéticos para produzir tecidos com propriedades que melhoram a desempenho dos atletas. $\mathrm{O}$ poliuretano da resistência ao fio (TEXTILEVINANT, 2014).

- Ingeo (PLA) - Provém da fermentação do açúcar do milho, vem sintetizado de um bio-polímero chamado ácido polilactideo, que pode ser transformado em fibra. Essa fibra pode tornar-se alternativa para o poliéster porque tem resistência igual ou superior a ele. Configura-se como recurso sustentável, renovável anualmente, biodegradável. Ele, em mistura ao algodão, resulta em um produto de malha mais confortável e resistente ao tingimento de cores fortes (AVELAR, 2010, p. 147).

\subsubsection{Fibras inorgânicas}

As fibras inorgânicas são provenientes de metal, vidro e cerâmica. Os metais como o cobre, aço inoxidável, bronze, prata e platina são os mais usados na construção de têxteis. Apesar da ideia de que os metais são um material rígido e resistente, eles também são moldáveis. Para serem usados como matéria-prima para têxteis, os metais encontram-se envolvidos com outras fibras, promovendo flexibilidade e resistência, adicionando elasticidade e no caso das fibras sintéticas, propriedades anti-estáticas.

A inclusão de fibras metálicas num têxtil proporciona qualidades antimicrobianas, antiodor, termoreguladoras e respiráveis (Braddock \& O’Mahony, 2005). Os tecidos produzidos com metal são maleáveis, de fácil manuseio, resistentes a mudanças de temperatura e recicláveis. 


\subsection{Fios}

Os fios são a principal matéria prima do segmento de VMMR. A primeira pesquisa a ser realizada na escolha da matéria prima de um produto de malharia retilínea são as qualidades e as propriedades do fio. A escolha de fios passa pelo estudo das propriedades da fibra, processo de fiação e coloração que o fio foi submetido, a fim de uma melhor adequação a estética do produto.

O fio é feito de dois ou mais cabos retorcidos que vão se juntando por meio de torção. A fiação pode ser definida como uma sucessão de operações através das quais se transforma a massa de fibras têxteis, inicialmente desordenadas em um fio de grande comprimento por meio de torção. A fiação dos fios envolve as torções das fibras descontínuas para tornar os fios contínuos (SISSONS, 2010, p. 16).

Os cabos são feitos de filamentos que são processados e torcidos na máquina de produzir os fios. O processamento das fibras passa pelas máquinas de cardagem, que consistem em grandes rolos cobertos com lâminas afiadas, criam uma fina manta de fibras, que são divididas em faixas estreitas, conhecidas como fitas de carda. As fitas de carda são retiradas e torcidas. Dependendo de quantos cabos se mesclam e a força de torção eles ficam mais macios ou mais secos.

Os fios provenientes de fibras naturais são de filamentos descontínuos curtos ou longos. Eles podem ser torcidos no sentido horário ou anti-horário, resultando em uma torção ' $S$ ' ou ' $Z$ '. O fio pode ser torcido com força, produzindo um fio duro e forte; ou pode ser torcido levemente, dando volume, maciez e menos força, mas com boas qualidades isolantes. Retorcer também impede que o fio se torça sobre si mesmo e deixa a malha final mais plana. De acordo com o número de fios singelos, muito finos e leves, combinados e com a forma como os fios são retorcidos, muitos efeitos diferentes podem ser alcançados. Fios de fantasia têm uma variedade de texturas e misturas de cores aplicadas na fase de fiação (SISSONS, 2010, p. 17).

Existem dois tipos de fiação quanto ao tipo de fibra:

- A fiação de fibra descontínua que é a junção de pequenos filamentos como na lã, algodão e o linho fios com fibras naturais se dividem em vegetais, animais e minerais como o amianto. Os animais são provenientes da lã de animais como lã, seda, angorá, cashmere, mohair, lhama, alpaca. 
- A fiação de filamentos contínuos ocorre por extrusão. Os filamentos extrusados podem ser agrupados e sofrer torção e outros processos, como a texturização. A fibra acrílica é a mais usada na malharia retilínea e na produção de fios contínuos por extrusão como o poliéster, viscose, poliamida, elastano, polipropileno, etc. Outros fios artificiais incluem fios metálicos, como o lurex, os quais são feitos de alumínio e revestimentos em plástica. Atualmente há um grande número de fios refinados e sofisticados disponíveis no mercado. Existem hoje microfibras extremamente finas, que abriram novas possibilidades na concepção de fios; fios com elastano estão sendo cada vez mais utilizados em roupas sem costura; e novas misturas e texturas são continuamente desenvolvidas (SISSONS, 2010, p. 20).

Os fios cardados naturais geralmente são feitos de fibras mais pobres, menos tratadas, com comprimentos mais curtos, de lãs mais quentes; por isso precisam de lavagem para explodir a fibra e torná-los mais macios. Geralmente todo o fio cardado tem lavagens com um procedimento mecânico com água e alguns produtos amaciantes.

A unidade de medida internacional usada para medir os fios de malharia retilínea é o TEX. Um TEX corresponde a um grama de massa por 1000 metros de comprimento. Essa medida equivale à espessura do fio que é denominada titulo do fio. Um fio pode ter um cabo, como, por exemplo, um cabo de lã com 50 TEX- titulo 1/50, ou dois cabos torcidos de um fio de acrílico de 14 TEX- titula - 2/28.

As indústrias de fiação geralmente enviam amostras de fios em desenvolvimento para as fábricas de malharia retilínea a fim de testarem a viabilidade em termos comerciais e de qualidade do fio e depois colhem relatórios das amostras e dos resultados antes de iniciarem a venda.

Um caso de instituição responsável por avaliações de fios é a fundação Blumenauense de estudos têxteis, FBET, SC, que aplica testes para controle nos fios de algodão para avaliar a qualidade do titulo, torção, regularidade, resistência e alongamento, aparência e atrito. Cada atributo pode influenciar no resultado obtido no produto final de VMMR. A torção, por exemplo, influi diretamente na resistência e maleabilidade do fio e do tecido.

Existe uma variedade muito grande de fios que, aliados aos pontos mais apertados ou mais soltos do vestuário, mudam completamente uma modelagem de uma peça de vestuário. Os fios com fibras mais porosas, como os naturais, tendem a alargar mais os pontos, enquanto os de fibras mais compactadas, como os sintéticos, tendem a deixar a malha mais encorpada e 
compactada. As malhas produzidas em máquinas com pontos de espessura mais grossas resultam com aparência de "feita à mão", artesanal (SISSONS, 2010).

Os fios acompanham as espessuras dos diferentes tipos de máquinas retilíneas. A figura abaixo mostra diferentes tipos de fios, formas e características diferenciadas com torções e trabalhados.

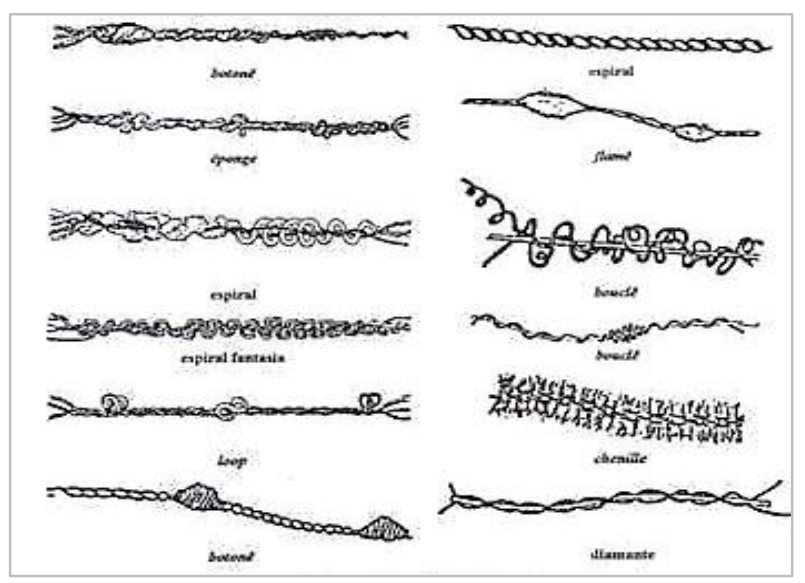

Figura 3 - Diferentes tipos de efeitos em torções e fantasia. Fonte: Medeiros (1999).

Estes efeitos elaborados de torções e irregularidades, chamados "fio fantasia", são produtos que os designers desenvolvem para acompanhar as tendências de moda no vestuário (MEDEIROS, 1999). Dentre eles, os mais usados são:

- Botoné - com efeitos de nozinhos no decorrer do fio.

- Flame - tem partes com espessuras de cabos com filamentos mais espessos e partes mais finas.

- Mescla - quando o fio é formado de cabos com mais de uma cor ou com tingimento de diferentes cores nos mesmos cabos.

- Frise - possui ondulações nos cabos dando um efeito de volume no tecer da malha.

- Chenile - Possui filamentos nos cabos, entrelaçados e cortados formando pelos.

- Diamante - Possui um fio principal que é envolvido enrolando em sua volta por um cabo ou mais cabos.

- Aspiral - os cabos são trabalhados e enrolados em aspiral.

- Loop - O fio tem um nós em intervalos do fio contínuo.

- Aspiral fantasia - combinação de fantasia e aspiral.

- Esponge - o fio é trabalhado de forma a ficar com cabos expandidos com folgas entre o retorcimento, de modo que quando se trabalha ele fica mais moldável e expandido. 
O fio fantasia pode ser composto com misturas de fios sintéticos, artificiais, naturais e suas misturas, além de eventualmente sofrerem processos de acabamento. Essas misturas tem como resultado um movimento de superfície, resultando em fios com construção diferente, com qualidades estéticas e de conforto especiais e voltados para a indústria da moda.

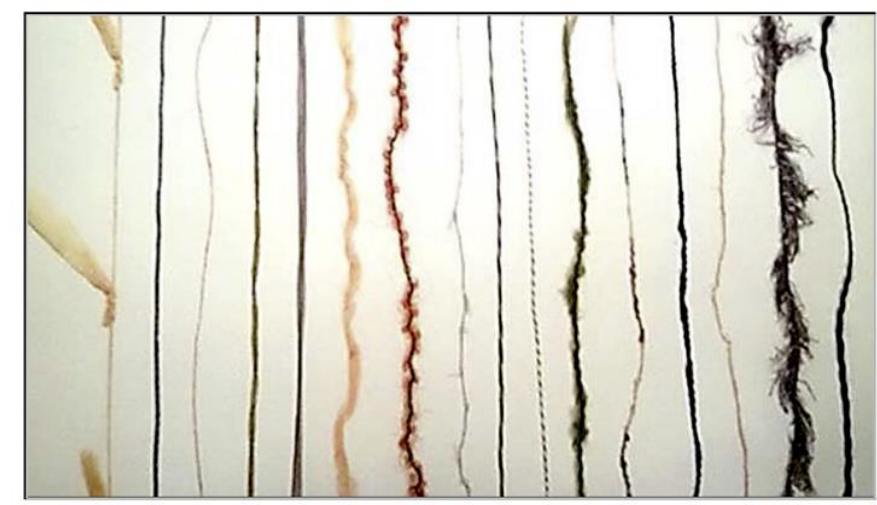

Figura 4 - Fios fantasia, exemplo de botonê, flame, mescla, felpado, frise. Fonte: Sissons, 2010.

Os fios têm muitas propriedades mecânicas que podem ser trabalhadas de diversas formas dependendo do maquinário escolhido. Uma das mais importantes funções na fabricação das malhas é a tensão em que o fio passa pelas agulhas na formação dos pontos.

Em diversos casos, dependendo de informações de mercado e de pesquisas técnicas, o fabricante de fio pode alterar as porcentagens da composição da matéria prima das fibras ou atuar em regulagens de mudanças de torção e especificações técnicas.

Segundo Sissons (2010, p. 16), “As vezes, por razão de resistência, design ou economia, os fios podem ser feitos de uma mistura de fibras descontínuas e filamento de fibras contínua". Com isso, vem crescendo a substituição de fios mais nobres, como a lã e o algodão, pela fibra sintética, ou mistura de vários tipos de fibras que possuem melhor previsibilidade de produção e preços mais baixos e sustentáveis.

Um exemplo de mistura muito usado no produto de VMMR é de 50\% algodão e 50\% acrílico, que fornece um fio que combina conforto e resistência. O avanço tecnológico usa misturas de materiais naturais com materiais sintéticos.

Os fios de fibras artificiais são fáceis de produzir e têm valor baixo, podendo ser misturadas a fios de fibras naturais. Os fios de fibras naturais podem ser usados sozinhos, ou misturados com os fios de fibras artificiais para dar uma maior qualidade como, por exemplo, resistência ou também para diminuir o custo do fio. Nos fios mais nobres feitos com fios de lã natural como cachemira e algodão muita vezes temos alguma porcentagem de poliamida que 
serve para dar estrutura de uso mais adequada na superfície dos tecidos em malha que pode ser de 4 a 10\%. Já o fio menos nobre pode chegar a $50 \%$ de poliamida o que significa na maioria das vezes baixa qualidade.

Fios texturizados são os fios modificados por operações mecânicas ou físicas (por torção, distorção, falsa torção, compressão, eriçamento, termo fixação oua combinação de várias destas operações), processos que permitem frisar, gofrar, encaracolar, etc. Os fios texturizados caracterizam-se por um significativo volume ou por uma elevada capacidade de alongamento.

As características técnicas dos fios normalmente são apresentadas juntamente com a cartela de cores, indicando procedimentos recomendados para o uso do fio e especificações técnicas como: porcentagens de fibra, amostra de fio de tecido já acabado, lavagem (se necessário), e referência de cores da estação.

Em geral, as cores oferecidas não estão disponíveis em estoque dos fabricantes. Os fios são preparados para tingimento e estocados com uma base neutra até chegarem os pedidos com as cores. Normalmente as fiações exigem uma quantidade mínima de 50 quilos para venda, mas constumam oferecer quantidades-piloto de até dois quilos para fazer testes de protótipos. No caso de pedidos com cores exclusivas, as fiações costumam atender acima de determinadas quantidades como, por exemplo, 500 quilos.

Um cuidado especial na compra dos fios é o número da partida do tingimento, que pode ser encontrado na etiqueta interna do cone ao qual esta enrrolado o fio. Todo fio que chega na expedição da fábrica provém de uma partida de tingimento, essas especificações são detalhadas na etiqueta interna do cone do fio. Vale notar que, na preparação dos fios para colocação na máquina retilínea, são necessários cuidados especiais de observação na etiqueta - o nome da fábrica, o titulo do fio, o número da cor e o número da partida que foi tingida.

As cores dificilmente são tingidas exatamente iguais em partidas diferentes, mesmo com as mesmas fórmulas de tinta. Por isso, ao comprar o fio pela segunda vez, este cuidado é essencial para que a produção não tenha com duas nuances de cor e de textura.

Uma vez separados os fios da cor escolhida com a mesma partida, ainda é necessário passar pelo processo de espular. Espular o fio é passar parafina no fio por um processo feito por uma máquina chamada espuladeira de fio. O fio é repassado de um cone para outro 
passando por um rolo de parafina como exemplificado na figura a seguir, a fim de deslizarem melhor no processo de tricotagem. Abaixo uma máquina denominada espuladeira:

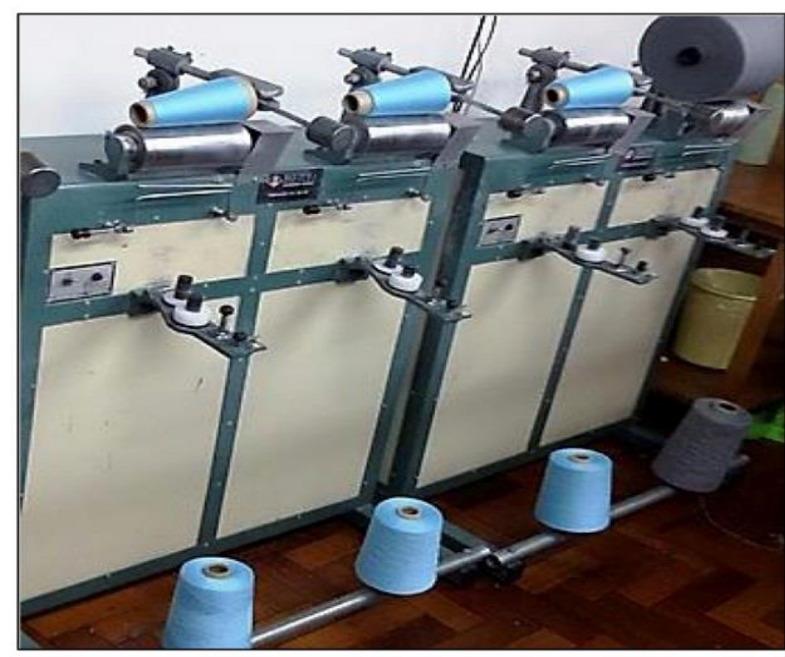

Figura 5 - Máquina de parafinar o fio, chamada espuladeira. Fonte: Malharia Gita, 2014.

Algumas empresas fabricante de fios oferecem um stock service, nome dado ao processo de estocagem de fios disponíveis para venda, já tingidos com as cores da cartela para cada fio especificado, e oferecem para venda a partir de um quilo de fio, serviço muito útil para as malharias. Normalmente os artigos deste estoque são fios mais clássicos e com mais consumo pelo mercado.

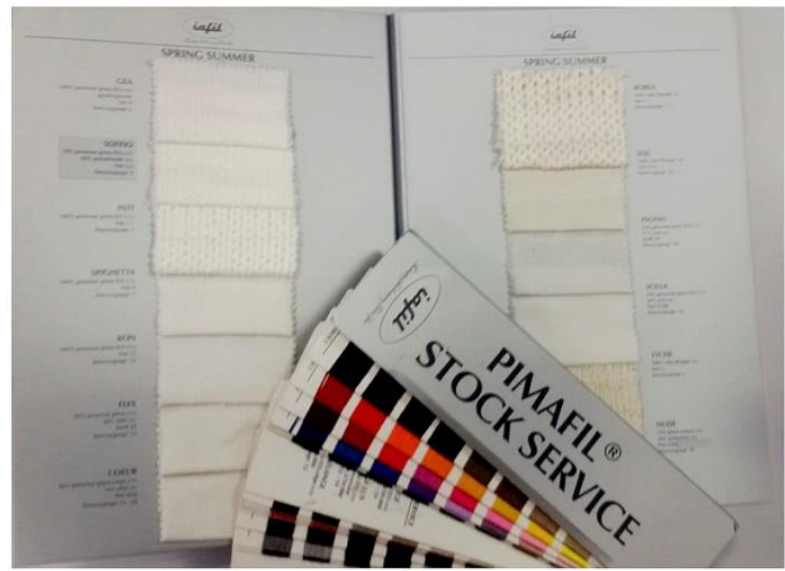

Figura 6 - Exemplo de "stock service". Fonte: IUAV, 2015.

O processo industrial de tingimento é parecido com o processo artesanal. Em processo artesanal os fios são tingidos com diversos corantes que são oferecidos no mercado e vêm com receitas de fácil uso. Os corantes podem ser ácidos químicos ou vegetais. Os corantes químicos resultam em cores fortes e brilhantes e têm excelente fixação de cor. Eles produzem 
uma bela variedade de cores, mas tendem a não serem muito carregadas de tinta com cores muito vibrantes, pois são mais propensas a desbotar quando lavadas. No entanto, são recursos que inspiram muitas coleções claras, estilo vintage. Com poucas cores, é possível obter uma ampla gama de cores, misturando e dosando a quantidade de corante. Ao fazer teste com essas misturas é importante, registrar as quantidades usadas em combinações, juntamente com uma amostra dos fios antes e depois como, por exemplo, $30 \mathrm{~g}$ de fio de lã, $40 \mathrm{ml}$ de vermelho/60 ml azul. Essa informação servirá como ponto de partida para novas variações. Antes de tingir, os fios precisam ser retirados dos cones, enrolados em meadas e amarrados frouxamente, para evitar o embaraço. Os fios também devem ser lavados para remoção dos revestimentos (SISSONS, 2010, p. 24).

Na Europa, os fios nobres chegam a valores de 40 a 150 euros ao quilo. A segunda linha, feita de misturas de fibras, tem o preço reduzido para 15 a 25 euros. A malha de verão mais nobre é tecida com algodão de diversas procedências. $\mathrm{O}$ algodão é produzido em países como a Índia, Egito, América do Norte, Caribe e Nova Zelândia, entre outros. Cada procedência pode corresponder a algodões com genética diferente, conduzindo a tamanhos de fibras variáveis. Quanto mais longa é a fibra, mais macios são os fios e maior é o custo, podendo atingir 100 euros por quilo. Outros fios clássicos de excelência como os cashmeres penteados e lãs de vicunha e merino, com fibras extremamente longas, chegam a custar 2.000 euros por quilo e são direcionados para as grandes maisons.

Uma mistura clássica é o algodão com cashmere para artigos de luxo e estão disponíveis em todas as finuras. O processo de mercerização, que torna mais translúcida a superfície do algodão, consiste em mergulhá-lo em soda. Outro processo que altera a aparência do algodão é submetê-lo a uma chama com velocidade altíssima, o que corta os pelos e confere uma aparência mais nobre. Atualmente existe uma tendência em trabalhar com fios muito finos e foram desenvolvidas máquinas até a finura 18, na qual cone de 1 quilo atinge 70 mil metros de fio, o que amplia o uso da malharia nas épocas mais quentes do ano.

A fabricação dos fios se desenvolve com o mesmo vetor de evolução das fábricas de malharia e suas máquinas; evolução que inclui não somente valor estético de textura, cor e peso, mas também variedade de critérios de desempenho. $\mathrm{O}$ efeito de memória de forma pode criar nos tecidos significantes e expressivos efeitos tridimensionais na sua forma ou superfície, proporcionando "vida" ao tecido. As malharias testam de modo sistemático os novos fios desenvolvidos pelas fiações pois, para perceber as suas propriedades precisam ser 
tecidos. O desenvolvimento de fios sintéticos se tornou um marco na historia da malharia retilínea do século XX como os fios de rayon, lycra e viscose incluindo fibras de fino poliéster, poliamida e viscose. Estes materiais são capazes de alta performance de elasticidade e misturas de absorção. Eles também são usados como revestimentos no setor pela saúde e tem habilidades de isolamento. Mais importante que a performance sportswear, as fibras contém wicking, a habilidade de manter o corpo seco, fora da umidade. Explorando os limites dos materiais, fibras, tais como a fenda de película a um tipo de poliéster de fio feita por vácuo, a selagem de uma camada de metal tal como o titânio, o crômio ou aluminio, ou a base de uma membrana de um nylon/poliéster, que é então cortada em tiras de rosca. Estes novos materiais estão a disposição dos designers para criar novos caminhos. Liocel, uma nova fibra de celulose, foi inventado pelo Courtauld em 1988, e recebeu o nome de marca tencell (FOGG, 2010).

A variedade de fios inteligentes e de werable computers ou wear-comps vem crescendo aceleradamente e passam a funcionar como uma espécie de segunda pele sustentável. Outros exemplos são os antiácaros, anti-UV, antichamas, ante-estresse e antibacteriológicos (AVELAR, 2009, p. 148).

Os têxteis inteligentes surgem como materiais aptos a sentir e a responder de maneira controlada ou prevista aos estímulos do meio ambiente, que podem ser de origem elétrica, térmica, química ou magnética. Como resposta a esses estímulos, estão mudanças da forma, cor, geometria, volume e outras propriedades físicas visíveis (RINALDI, 2010).

Efeitos incomuns em fios são alcançados variando-se com a cor, com a textura e com os ajustes de calor. Esses efeitos podem ser adicionados à fibra nas fases de fiação ou de retorção. Por exemplo, um fio misturado tem diferentes cores combinadas no estágio de fibra. Um fio mescla é composto por dois fios singelos de lã fiados, em cores diferentes, torcidos juntos (SISSONS, 2010, p. 22).

Em 2012, na Pitti Filati, importante feira de tecnologia do setor, o Grupo Lineapiu, Itália, uma empresa líder do mercado italiano, lançou um fio com identidade (código de barras), propiciando a busca da veracidade do produto com um simples leitor óptico, o que dificulta ainda mais as falsificações. Outro importante lançamento do grupo foi a mistura da viscose com o polipropileno; possibilitou a criação de produtos que, em contato com o calor, se transformam, modelando-se no corpo. Ao lavar a peça, o "tecido" volta ao normal (LINEAPIU, 2012). 
Em 2014, a feira mostrou um direcionamento para fios leves, macios e irregulares, com uma consistência de pelos, muito macios ao toque, refinados e pesquisados com efeitos "Techno", com fibras nobres para o mercado de luxo.

O Lanifício Cariaga, italiano, desenvolveu um fio de cashmere tridimensional. A empresa de fios do grupo Filpucci escolhe fios híbridos e com cores virgens.

A Feira Filo Milão Outono/Inverno 2016/17, mostrou tendências claras e muitos fios diferentes para uso no inverno e outras estações do ano. Janet Prescott descreve a feira:

"O foco de mercado para os fios se expande com sinais de que os fios para decoração de interiores, acessórios e malhas feitas a mão estão se tornando importante; há uma crescente demanda de fios handknitting na moda, incluindo fibras misturadas com lãs mais caras, como seda e cashmere, alpaca, merino e mohair; as fibras naturais e fios preciosos foram à tona; os fios estão mais espessos, marcados por uma textura mais invernal de lã com muitos fios escovados e provocados por pilosidade; na confecção de malhas, casacos e sobretudos, os fios são de poliamida, poliéster, seda, linho; os fios com fibras metálicas e com fio de Lurex se misturam com as lãs de merino, cashmere e seda estão com cores exóticas, tons profundos de joia, com transparência especial tingimento para vários fios e misturas, são pequenos pontos de brilho em muitos fios; os produtores italianos mostraram fios de estilo britânico como os fios melanges com um aspecto retro. Os clientes relatam querer um olhar irregular para a superfície da malha, com efeitos de textura nas diferentes misturas. Muitas misturas interessantes de fios como cashmere, metais coloridos, algodão, viscose, bambu, rami e cânhamo, seda, tencel, modal, cupro. (Filo Milão, Outono / Inverno 2016/17, Janet Prescott, Knitting industry). (Janet Prescott, knitting industry).

$\mathrm{Na}$ figura a seguir, algumas amostras de fios da feira FILO, Milão, para tendência 2016/17, com fios espessuras mais finas e misturas de fibras naturais e sintéticas.

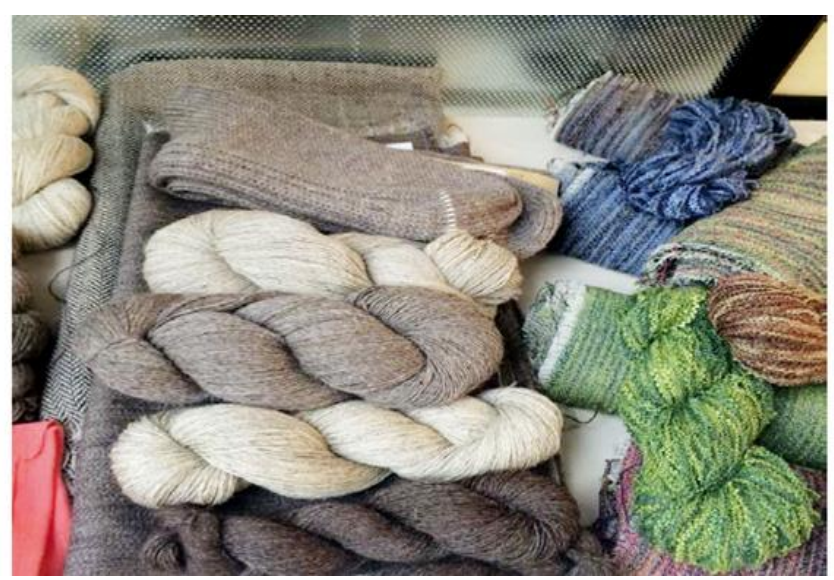

Figura 7 - Filo 2016/2017, Milão, tendência para o inverno, Knitting Industry. Fonte: Janet Prescott, 2015. 


\subsection{Malharia}

Os tecidos são as matérias-primas principais do produto de vestuário. São divididos em tecidos planos, não tecidos e tecidos de malha (Mendes, 2009, p. 35).

a) Tecidos planos - Os tecidos planos são artigos produzidos em tear e formados pelo entrelaçamento perpendicular alternativo por, no mínimo, dois grupos de fios, os de urdume e os de trama.

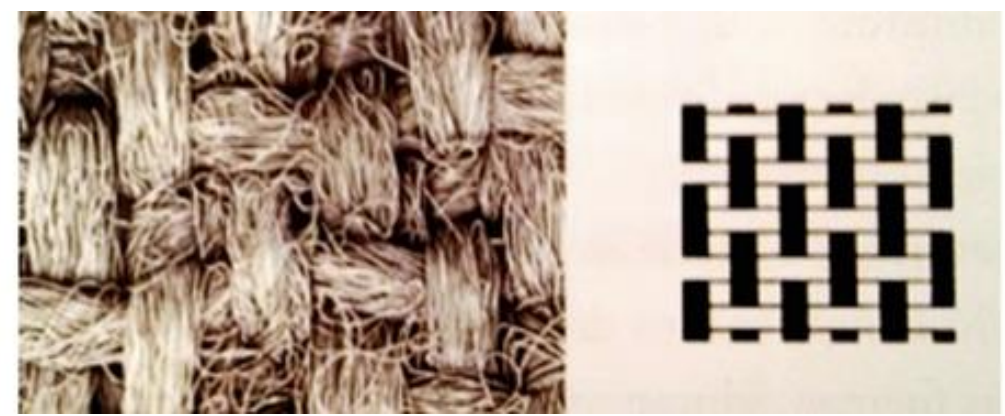

Figura 8 - Estrutura de tecido plano. Fonte: JONES, 2005

b) Não tecidos - Tem uma estrutura plana, flexível e porosa, constituída de véu ou manta de fibras ou filamentos orientados direccionalmente ou ao acaso, consolidados por processo mecânico (fricção e/ou químico como adesão) e/ou térmico (coesão), ou pela combinação desses.

c) Tecidos de malha - O mecanismo de tricotagem consiste na formação de laçadas de fios com ajuda de agulhas finas e pontiagudas. O entrelaçamento e a formação contínuos de novas laçadas produzem os tecidos de malha.

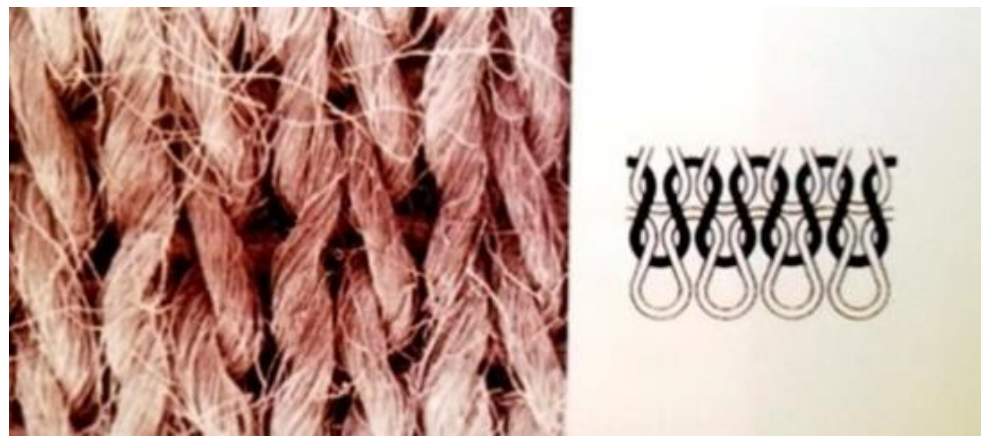

Figura 9 - Estrutura de tecido de malha. Fonte: JONES, 2005.

Em malharia por trama, utilizam-se teares retilíneos e teares circulares, enquanto que em malharia por urdume, utilizam-se basicamente teares Kettenstuhl e Raschel. Na malharia por trama pode-se utilizar dois tipos de máquinas, também denominadas teares, que podem 
ser retilíneos ou circulares. Na figura a seguir, vemos em um estudo do SEBRAE, 2012, no polo de sul de Minas um esquema de subcategorias dentro da confecção de malhas em trama.

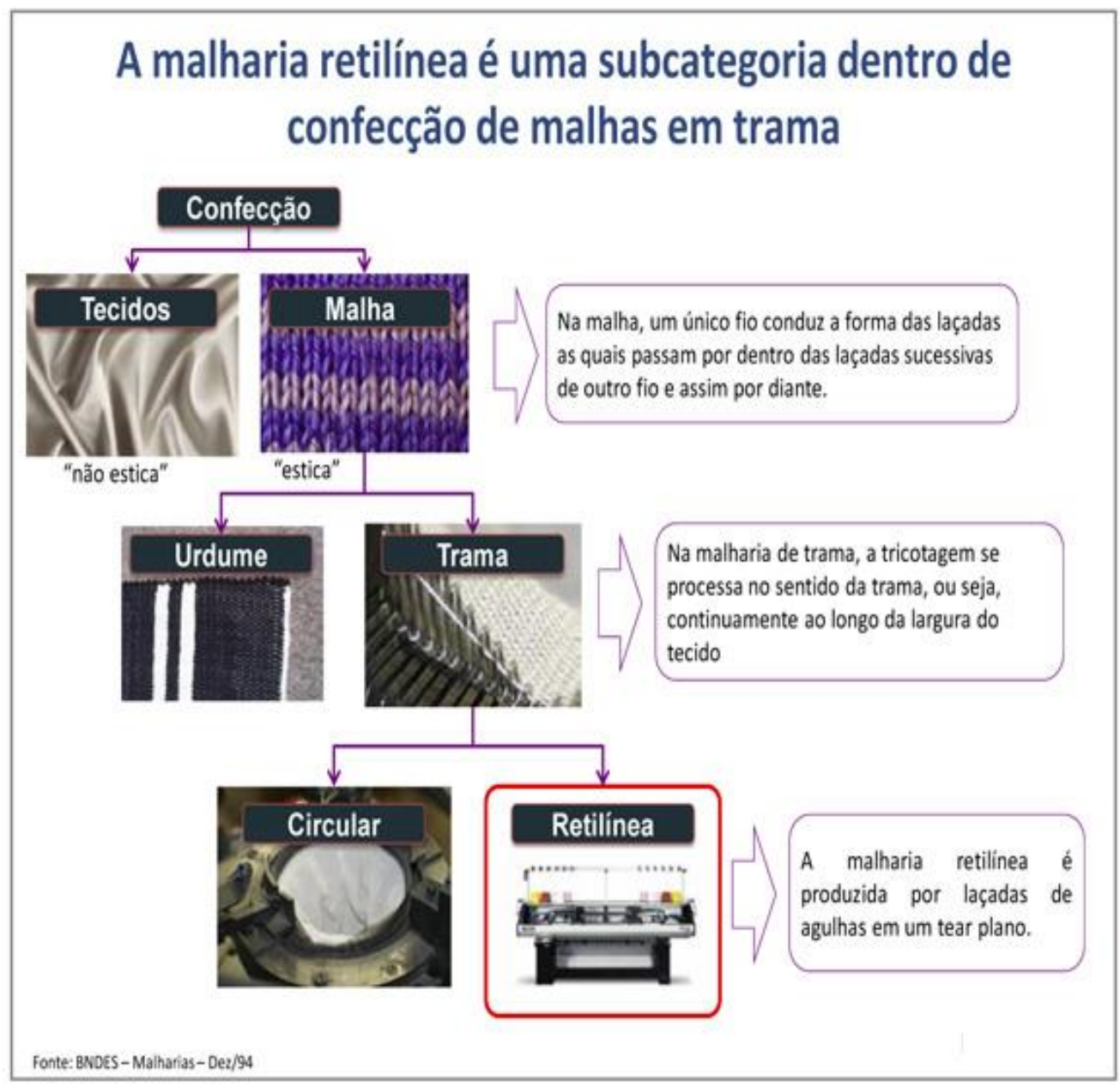

Figura 10 - Esquema de base de tecido de confecção de Malharia. Fonte: SEBRAE, 2012.

A) Máquina retilínea - o tecido de malha é produzido por máquinas com dupla fronturas (placas de agulhas) retas e podem ser manuais e eletrônicos.

- Máquinas retilíneas manuais - São máquinas retilíneas que produzem o tecido de malha feito com a manipulação direta e mecânica do homem. A construção das malhas em máquinas manuais era demorada e dependiam muito da habilidade do homem em manipular os entrelaçamentos do fio com as agulhas para dar forma aos pontos trabalhados e com relevos do tecido. O trabalho de diferenciação e de criação era feito de ponto em ponto, resultando em um processo demorado e com muitas falhas. As primeiras máquinas de tricotar foram construídas no século XVI e a base do mecanismo de tricotar é a mesma até os dias atuais. Atualmente, se trabalha com dois tipos de máquinas manuais: as caseiras e as industriais (SISSONS, 2010). As 
máquinas caseiras são utilizadas em trabalhos artesanais e são pouco produtivas como mostra a figura a seguir:

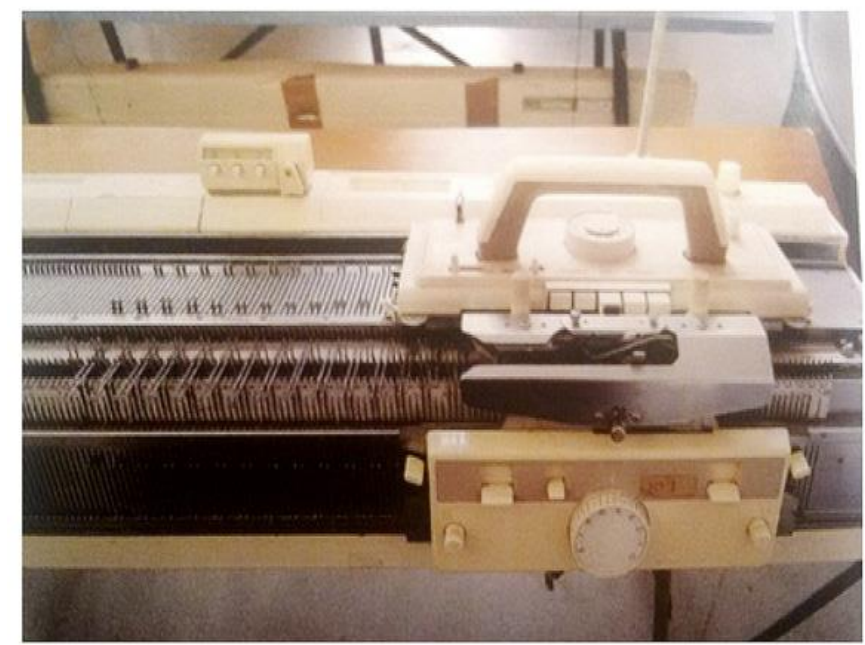

Figura 11 - Máquina de tecer manual de uso caseiro. Fonte: SISSONS, 2011.

- Máquinas retilíneas manuais industriais - São utilizadas em indústrias para peças artesanais e para detalhes decorativos. Também utilizadas nas escolas de técnicos e de estilistas de moda para aprendizado dos princípios básicos de tecimento em malharia retilínea. Na figura a seguir, uma máquina retilínea manual com dupla frontura, duas placas em formato de "V", também chamadas de " $V$ - $B E D$ ", que contém as agulhas.

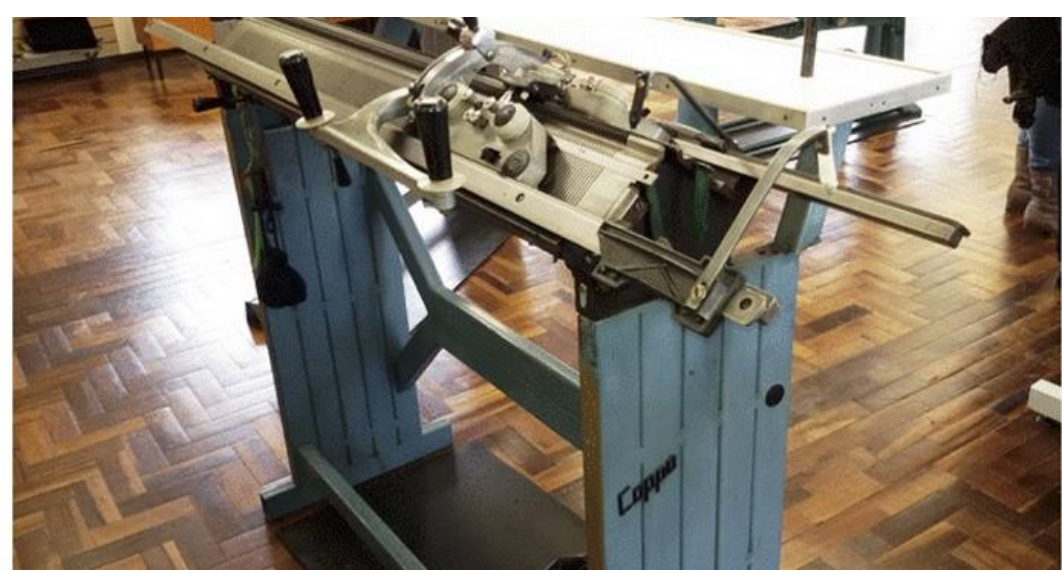

Figura 12 - Máquina de Malharia Manual da Universidade de Caxias do Sul. Fonte: UCS, 2014.

- Máquinas retilíneas eletrônicas - Com a evolução das tecnologias, hoje temos incorporados diversos recursos tecnológicos e sistemas na produção dos tecidos de malha. Os recursos das máquinas retilíneas são as engrenagens comandadas eletronicamente para a seleção das agulhas e ativação das técnicas de tecelagem. O 
avanço das tecnologias mecânicas, eletrônicas e informacionais trazem uma nova dinâmica ao processo de construção criativa muito mais rápida e perfeita. Um dos principais fatores é o tempo, pois os movimentos são precisamente os mesmos em todas as etapas e o fazer mecânico é controlado por computadores que desenvolvem o movimento sempre igual e na mesma força e tensão. Os teares retilíneos têm muitas espessuras que são denominadas finuras ou galgas, com graduação de três até 18. As máquinas eletrônicas se dividem em longas e compactas. As máquinas longas têm até dois metros e oitenta centímetros de frontura, e são utilizadas para produzir painéis moldados no sistema fully fashioned. Na figura a seguir, uma máquina compacta que produz peça pronta inteira, sem costura, seamless, no sistema Wholegarment.

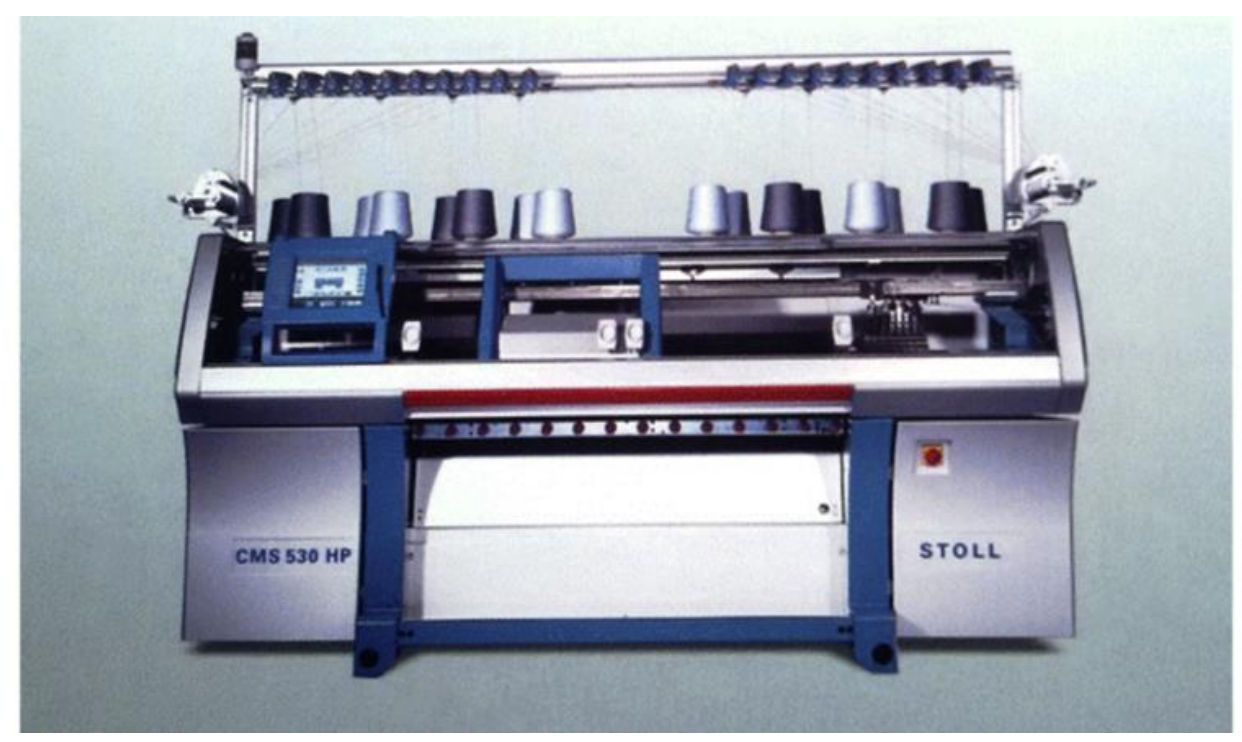

Figura 13 - Máquina Eletrônica compacta de última geração. Fonte: Stoll, 2013.

O desenvolvimento de produto do produto de vestuário de moda na malharia retilínea (VMMR) parte do entendimento da construção das características da fibra que contém no fio a ser tecido em malha, diferentemente dos outros tecidos planos e não tecidos que já se apresentam prontos para a confecção do vestuário. A criação dos produtos VMMR parte de fatores como textura, caimento, elasticidade e propriedades mecânicas do fio. Essas características influenciam na construção do tecido de malha retilínea que têm qualidades específicas variando de acordo com os fios de diferentes fibras e suas particularidades.

Segundo Richard Oliveira (SENAI, 2013):

"Enquanto na tecelagem de tecido de malha os fios de trama e de urdume formam uma armação rígida, na malha, um fio conduz a forma das laçadas as quais passam por dentro das laçadas sucessivas de outro fio, e assim por diante". 
Conforme as escolhas dos processos produtivos, as diversas possibilidades de pontos e fios e a experiência e sensibilidade do programador, o vestuário de malha retilínea resulta em modelagens e estéticas diferenciadas e inovadoras.

\subsubsection{Tecimentos e Pontos na Malharia Retilínea}

Designa-se ponto de malha o conjunto de entrelaçamentos constituídos a partir da utilização de certos recursos da máquina. Com os recursos básicos, comuns a todos os tipos de máquinas retilíneas, são tecidos pontos como o canelado, malhas de direito e de avesso técnico, malha cheia, malha cordão e malha inglesa ou com fang (BREHM, 2010, p. 3).

Esses pontos são laçadas de fio que, passados dentro das agulhas, formam nós que vão prendendo uma laçada na outra. As laçadas presas por nós formam as carreiras. O tecido de malha é a junção de carreiras. Para formar o tecido de malha, uma carreira deverá estar sempre entrelaçada com a carreira superior e inferior a ela, exceção feita à primeira carreira e à última carreira (SANCHES, 2002).

O tecido de malha retilínea é produzido por meio de um mecanismo que consiste levar o fio até às agulhas por um carrinho produzindo as laçadas e, consequentemente, os pontos. A agulha de máquina é composta por uma ponta em forma de gancho e pela lingueta que prende e solta o fio, conforme o movimento de descer e subir da agulha, que passa pelas ranhuras ou bitolas de duas placas.

O carrinho desliza em placas retas denominadas fronturas. A frontura é uma barra com carreiras de fendas por onde as agulhas são encaixadas lado a lado, formando um v onde as agulhas se encontram e passa o fio. Um carrinho com porta-fios passa pelas placas e entrelaçando o fio nas agulhas, formando uma corrente de malha. O carrinho desliza sobre duas barras onde as agulhas são encaixadas uma após a outra formando duas fileiras, uma na frente da máquina e outra na parte de trás da máquina que se chamam fronturas. As agulhas estão deitadas sobre estas fendas, a fim de deslizarem para baixo e para cima, para laçar o fio e formar o ponto. As sucessões de pontos formam carreiras. As carreiras vão se sobrepondo com o passar do carrinho e formam o tecido. O movimento de ida e volta do carrinho, combinado com o movimento subir e descer das agulhas formam os pontos do tecido de malha. Quando o carrinho vai de uma ponta a outra da máquina, denomina-se passada. Em cada passada do carrinho sobre as agulhas formam uma carreira de pontos. Esse movimento 
de vaivém do carrinho denomina-se volta; quando ele completa a volta, formam duas carreiras de pontos.

A carreira chega a ter duzentos pontos nas malhas com espessuras das agulhas mais finas até cinquenta pontos nas malhas de agulhas de espessuras mais grossas. Cada ponto corresponde a uma agulha. As fronturas medem de um metro e vinte centímetros até três metros de comprimento.

As primeiras máquinas foram concebidas para fabricar meias e tinham uma frontura. A partir do século XVII as máquinas para a fabricação de vestuário passaram a ter duas fronturas. O carro da máquina que leva os fios e levanta as agulhas passa por essas duas placas que são apoiadas em forma de um $\mathrm{V}$ ao contrário, por esse motivo o tear retilíneo também é chamado por V-BED. Com o tempo foram se desenvolvendo diferentes processos de fabricação das malhas com maquinário denominado malha de urdume e malha de trama. Este mecanismo abrange a malharia retilínea e a malharia circular. Na malharia de urdume, o fio é alimentado individualmente para cada agulha e é tecido pelo entrelaçamento no sentido do comprimento. Para estes dois tipos de classificação existem maquinários distintos.

A malha mais simples de ser tecida é a malha plana que sai naturalmente do entrelaçamento dos fios com as agulhas, não necessitando outro tipo de operação. Essa malha é a base dos tecidos de malharia e denominada malha Jérsei, ou meia malha, pois utiliza só um lado de placa da máquina que é denominada frontura. As figuras a seguir, mostram o direito e avesso do tecido de malha.

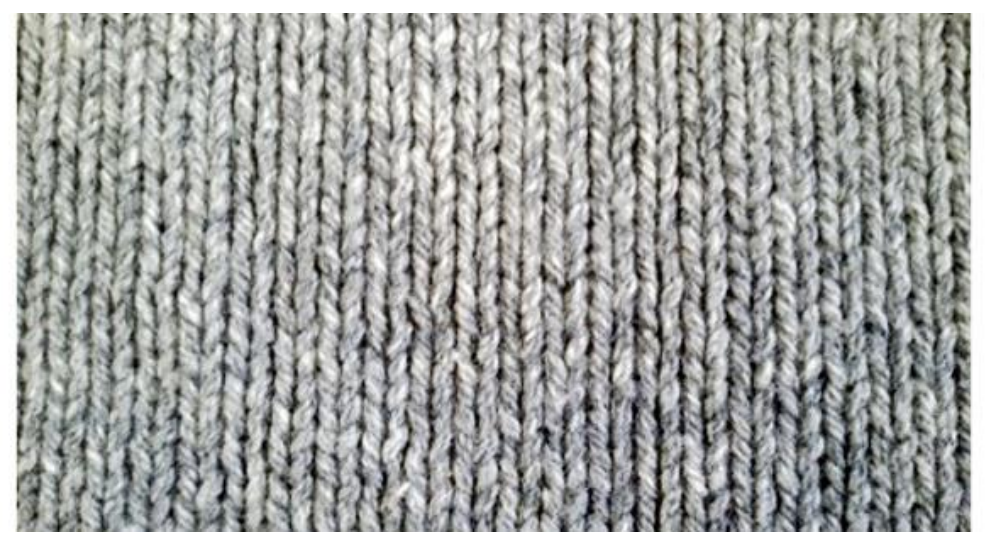

Figura 14 - Malha Jérsei ou meia malha - lado direito. 


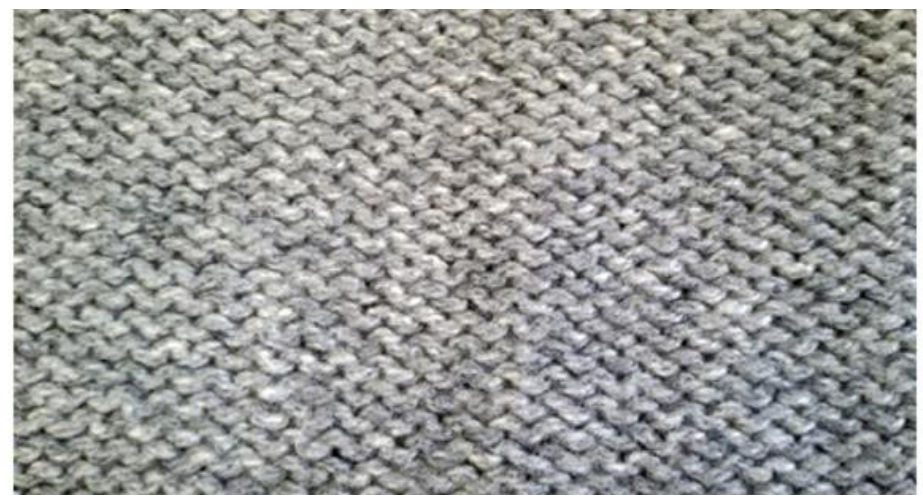

Figura 15 - Malha Jérsei ou meia malha - lado do avesso.

Segundo Faerm (2010, p. 65) os pontos essenciais de base para a concepção do tecido de malha para o produto de VMMR como mostra figura a seguir:

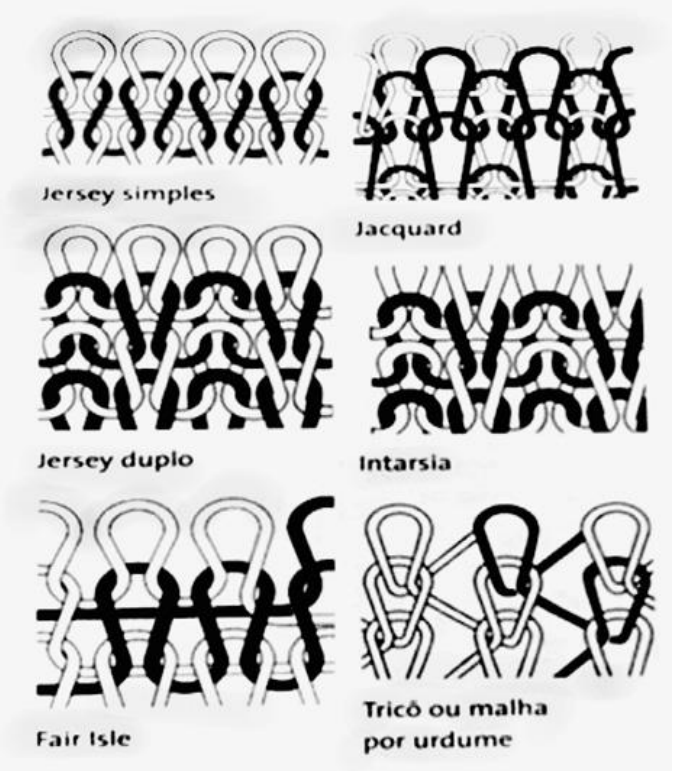

Figura 16 - Pontos mais usados nos tecidos de malha retilínea no produto de malha. Fonte: Faerm, 2010.

A. Jérsei simples ou meia malha - o fio percorre só a parte da frente da máquina. $\mathrm{O}$ lado da frente tricotado é mais macio e uniforme. A produção de tecido de Jérsei é feita em máquinas que possuem um único conjunto de agulhas (frontura). No entanto, também podemos tecê-lo em máquinas que disponham de dois conjuntos de agulhas (dupla frontura), onde naturalmente só se verificará o tecimento num dos conjuntos da agulha (frontura).

B. Jérsei duplo ou interloque - utiliza um conjunto duplo de agulhas, a parte da frente e a parte de trás da máquina. 
C. Malha rib. - (sanfonado ou canelado) o fio percorre alternadamente agulhas da placa da frente e de trás da máquina formando uma sanfona.

D. Fair isle - um tricô de Jérsei simples com pequenas estampas; utiliza duas cores de fios ou mais. O lado direito tem uma superfície com a padronagem desenvolvida e o verso tem fios soltos, pois o fio pula a agulha para fazer o desenho.

E. Jacquard - malha de Jérsei duplo formando estampas, geralmente são de quatro cores porque a estampa é formada liberando um dos fios na frente, enquanto os outros três, ficam do avesso. Usada para tecer relevos com técnica de transferência de fios de uma agulha para outra, com a passagem de mais de uma cor, com o uso de vários portafios. Mais de quatro cores podem ser usadas em uma carreira, Joseph Marie Jacquard, mecânico, produziu um sistema que em teares de cala, selecionava fio a fio e tinha como forma de armazenamento da informação em cartões perfurados, isso tudo no século XVIII, muito antes do advento dos sistemas de informação como conhecemos. Os armazenamentos hoje são desde os cartões perfurados, tambores selecionadores, memórias eletrônicas com dispositivos acionadores e correntes de elos específicos. Hoje com as novas tecnologias, tecemos um tecido de malha com até 36 cores.

F. Intarcia - método de produzir padrões de estampas e geométricos coloridos por meio de programação de máquina por troca de porta fios. Este método é bem trabalhoso, mas com o avanço da tecnologia já se consegue trabalhar com várias cores ao mesmo tempo em uma só passada. Nessa técnica não há fios soltos, pois cada cor é tecida na sua própria forma. Carros especiais de interilha estão disponíveis para máquinas mais sofisticadas.

G. Malha de urdume com malha de trama - um híbrido de malharia e tecelagem que utiliza um cilindro de fios de urdume unidos por grade móvel de agulhas. O tecido produzido não desfia nem desmancha; são utilizados para roupas de banho, moda e lingerie.

Dependendo do número de agulhas por polegada dispostas sobre a frontura, isso é, quantidade de agulhas por quantidade de intervalo medida (bitola) em que a placa contém, especificamos qual a finura que a malha vai resultar. As máquinas de malharia têm agulhas com diferentes espessuras e comprimentos. Essa diferenciação tem como característica específica produzir tecidos que podem ser de espessura muito fina até espessuras mais grossas. Esta variação de espessura do tecido de malha é denominada finura ou galga. 
Finura ou galga é um termo utilizado para especificar as diversas espessuras que as máquinas retilíneas podem produzir e que é o resultado da quantidade de agulhas existentes em uma unidade de medida. No Brasil, utiliza-se o sistema inglês, ou seja, quantidade de agulhas por polegada $(2,54 \mathrm{~cm})$ conforme a frontura da máquina. Exemplo: finura cinco (5 agulhas em 1 polegada). Então, conclui-se que, quanto maior a finura, maior a quantidade de agulhas por polegada e, portanto, elas deverão ser mais finas. Uma grossura maior de tecido de malha é produzida com agulhas mais grossas e com fios mais grossos e consequentemente agulhas mais finas e fios mais finos, resultam em malhas mais finas e com menor peso.

A finura de espessura mais grossa do produto de VMMR é denominada número 3 - a mais fina é de número 18. Na máquina retilínea as finuras ou galgas vão de um ponto de finura da máquina número 3 que é comparado ao tricô grosso feito à mão com vários cabos passando pela finura ou galga $5,7,8,10,12,14,16$ - até máquinas de finura 18 que tem o comportamento mais fluído e com pontos muito pequenos produzindo tecidos muito finos.

Segundo Dykes R. e Enticknap S. (2013) em apostila Learn industrial Machine knit, de máquinas retilíneas eletrônicas, também chamadas V-BED, são usadas para vestuário de malha e muitos outros produtos. As máquinas tem um intervalo entre as agulhas, também denominada de bitolas, diferentes, que resultam nas diferentes espessuras dos tecidos de malha, denominada finura ou galga, incluindo 14, 12, 10, 8, 7, 5, 3. (2012, p. 2, Tradução nossa).

O carrinho que transporta o fio para as agulhas foi aperfeiçoado, sendo inseridos mecanismos de chaves para aperto de tensão do fio. Foi também inserido um mecanismo de levantar e baixar as agulhas, de acordo com o desenho da malha. A inserção desse mecanismo foi muito importante, visto que, na máquina manual, ele é feito por um instrumento chamado pulsão. O carrinho que leva o fio para as agulhas, passando por dispositivos que interferem e determinam a diferenciação e formação do tecido. Esses dispositivos vão apertar, soltar ou modificar os pontos da malha dependendo do resultado táctil e aparência que o estilista quer mostrar na sua criação. 


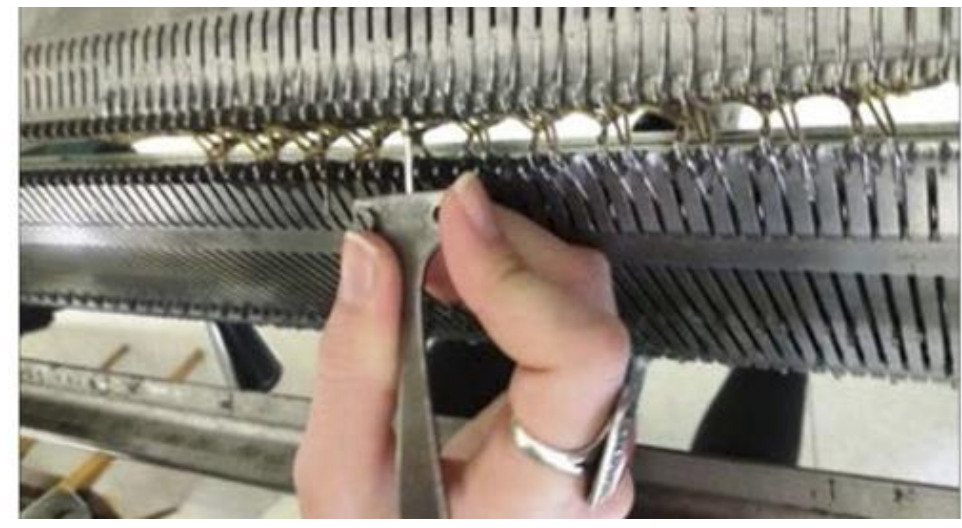

Figura 17 - Instrumento para transferência de pontos entre as agulhas na máquina manual industrial. Pulsão de transferência de pontos em método manual. Fonte: Laura Piccinini, IUAV, 2015

Esse instrumento levanta o ponto da agulha por onde passa o fio e coloca este ponto na agulha ao lado. Este deslocamento do ponto deixa um vazio formando buracos nas malhas. Os acavalamentos e vazios formam os desenhos que se pode ver nas malhas, como tranças e trabalhados. As figuras a seguir apresentam diferentes pontos que podem ser observados.
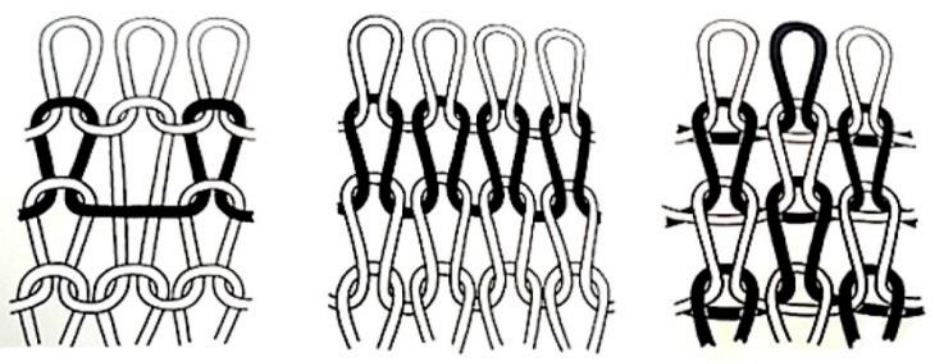

Figura 18 - Pontos de Máquina retilínea. Fonte: SISSONS, 2011, p. 76.

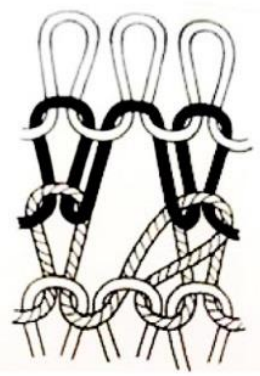

Figura 19 - Máquina retilínea, transferência de pontos, transferência de ponto. Fonte: SISSONS, 2012, p. 76. 


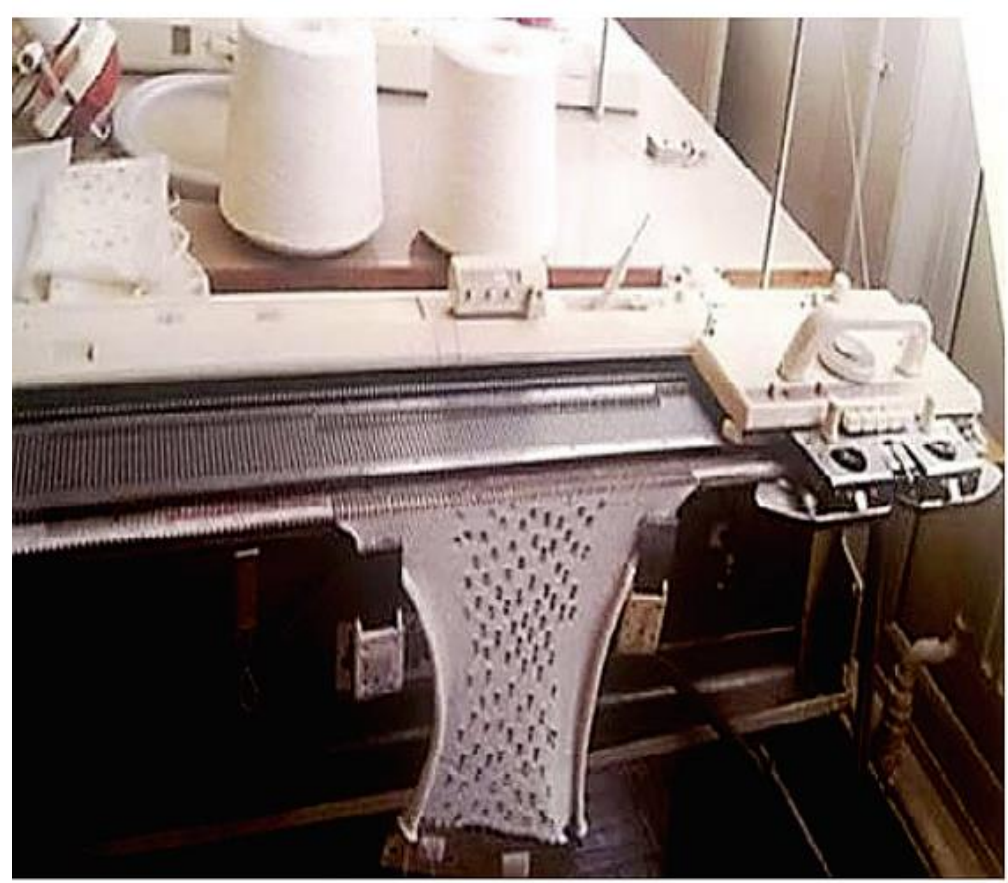

Figura 20 - Tecido produzido em máquina retilínea manual com efeitos de trabalho feito com transferência de pontos. Fonte: SISSONS, 2012, p.28.

As estruturas formadas no tecido podem ser com laçadas que passam por todas as agulhas ou que pulam as agulhas. Esse mecanismo de pular, que deixa o fio flutuante, é determinado pelos acionamentos do carrinho. O jogo de pular a agulha, forma pequenos buracos no tecido, dá origem aos padrões rendados e desenhos das malhas retilíneas. Podemos observar na figura a seguir, alguns pontos executados nas primeiras aulas de malharia retilínea nos centros de treinamento.

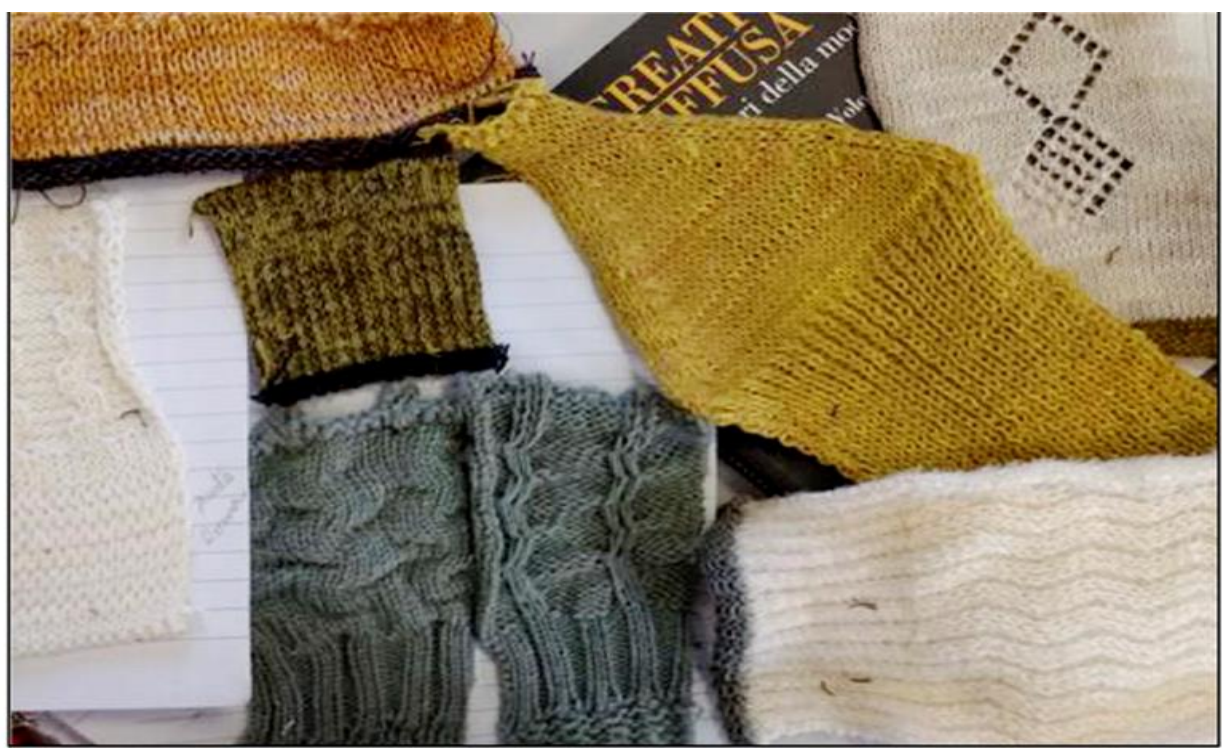

Figura 21 - Pontos Basicos em malharia retilínea Fonte:Laura Piccinini, 2015 IUAV. 
Rech (2002), afirma que "utilizando maquinário mais moderno, é possível elaborar modelos mais complicados tecnicamente (pontos abertos, rendados, vazados, fully fashioned) a um custo menor, já que o tempo de programação e produção torna-se baixo e com menos possibilidade de defeitos e falhas".

Sissons (2012, p. 92) diz que a evolução das máquinas de malharia passou pela malha simples e foi evoluindo com diversas outras técnicas como:

- Tranças - é feita com a transferência de vários pontos de umas agulhas para outras, construindo desenhos com formações de contrastes com o avesso e o direito do tecido de malha. A figura a seguir, apresenta desenhos de tranças construídas com efeitos de avesso e direito de transferências de pontos.

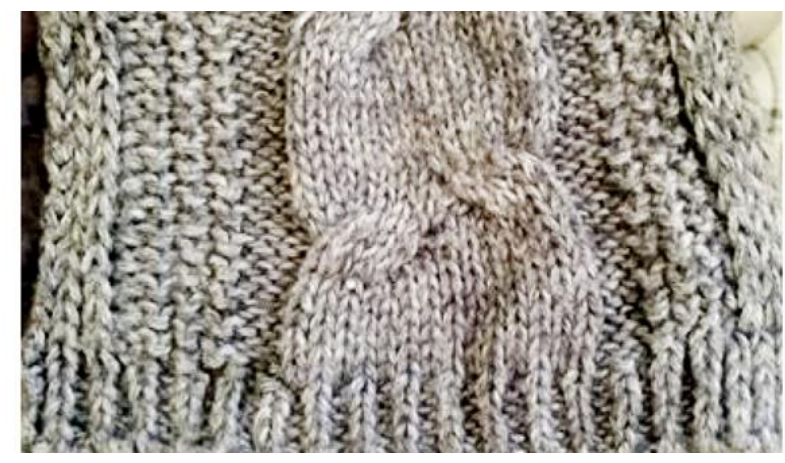

Figura 22 - Desenhos de tranças construídos com transferências de pontos (registro do autor, 2015).

- Calados: os movimentos de sobreposição dos pontos formam o calado. Os Calados possibilitam a diminuição de larguras nos tecidos por meio de acavalamento dos pontos nas agulhas laterais. Nos calados, a quantidade de pontos e carreiras, acrescentados ou tirados, definem o formato do molde, formando cavas e decotes. O Calado é trabalhar com os pontos das agulhas com um dispositivo e laçar, de dois em dois pontos ou mais, para as agulhas de dentro, a fim de fazer o contorno da cava da manga ou do corpo. Na maioria das vezes ele é para reduzir a largura para formar cavas e decotes. Ele também pode ser para fora, em vez de diminuição há um acréscimo de pontos que pode, por exemplo, dar mais amplidão as peças mais soltas. Este trabalho de acréscimo é muito usado em golas e detalhes em peças assimétricas. Na figura a seguir, se observa a junção de uma cava da manga com a parte do corpo. Os calados das duas partes se encontram. 


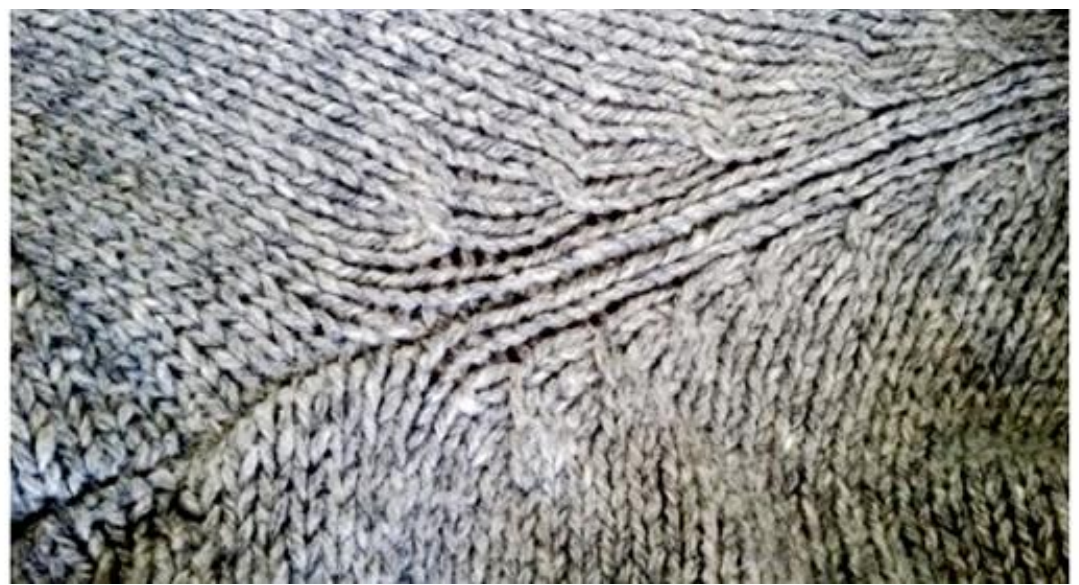

Figura 23 - Emenda da manga com calados de diminuição. (registro do autor, 2015).

Na programação dessas peças de produto de VMMR no computador é difícil prever os encolhimentos do final da peça. O usual é tentar chegar ao tamanho por intermédio de ajustes nas regulagens dos tensores da porta-fios, isto é, um mecanismo que existe nas máquinas onde os fios passam antes de descer para serem trabalhados pelo carrinho que vai passar pelas agulhas e tecer a malha.

Ainda existe o sistema do carrinho que passa pelas agulhas o qual dependendo da disposição das agulhas e dos mecanismos de travas dentro do carrinho, tece uma infinidade de padrões e apertos que resultam em estruturas diferentes. A transportadora que alimenta os fios mantém o fio no lugar enquanto produz o tecido de malha.

Esta tensão, em geral, determina o compactamento do tecido: ele pode imprimir propriedades elásticas da malha conforme o grau de tensão imposta. Os tecidos de malha obtidos a partir desse processo apresentam desempenhos específicos de acordo com a funcionalidade do produto: práticas esportivas, meias de compressão, lingerie e outros segmentos. As malhas usadas para prevenir doenças são muito compactadas, resistentes e com poder de compressão alto.

O tênis da empresa Nike em parceria com a empresa Stoll demorou seis anos de pesquisa para ser lançado. O tênis foi projetado com o sistema de peça pronta, seamless, de malhas de máquinas retilíneas sem costura, com uma combinação de técnicas de intarcia e jacquard para criar desenhos e cores diferenciadas com estrutura flexível e confortável. 


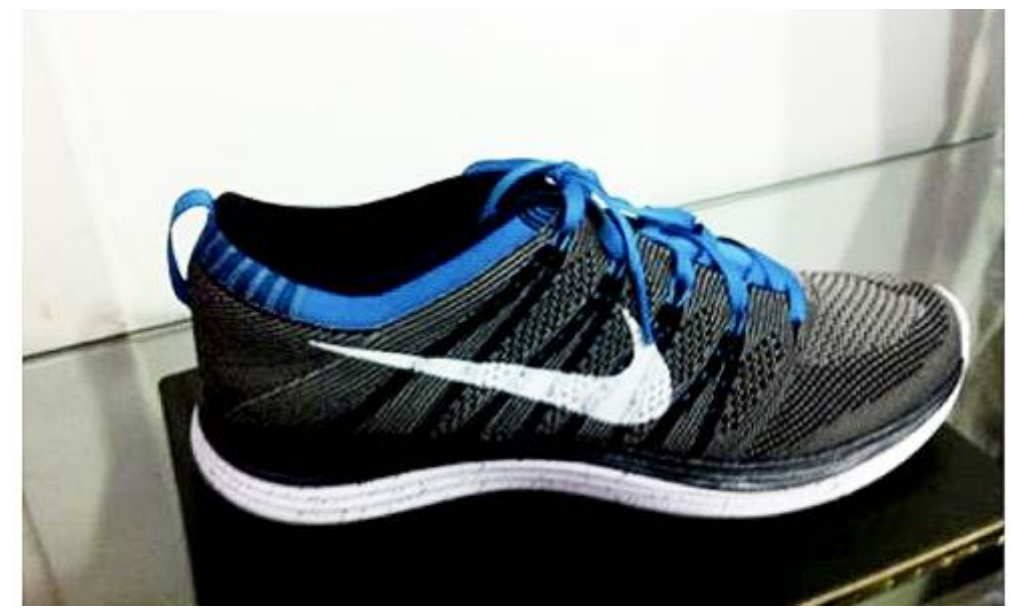

Figura 24 - Tênis Nike, 2012. Produzido com tecnologia de Peça Pronta. Fonte: Stoll, 2012.

Os últimos lançamentos da Nike produzidos com a técnica Flyknit das máquinas retilíneas da Stoll possuem suportes Flywire. Flywire são fios que passam pelo tricô no sentido da trama durante o tecimento, proporcionando uma estrutura de malha com apoios mais seguros. Essa técnica é uma inovação que mescla a técnica de malha com tecido plano. O tecido de malha é tecido com fios ou cabos Flywire de forma assimétrica, que envolve o pé e fornece suporte sem o volume dos modelos anteriores, para proporcionar um movimento natural, melhorar o conforto e respirabilidade. O tênis é tecido com fios muito leves tanto na trama quanto no urdume, com uma estrutura que não desfia para dar a sensação de segunda pele. O Dri-FIT Knit é um tecido ultramacio, criado para ajudar a manter ótima temperatura, para melhor performance nas mais variadas condições climáticas. Essa tecnologia emprega diferentes padrões de malha que são visíveis e ajudam a controlar a ventilação da malha.

\subsubsection{Máquina de Malharia Retilínea Eletronicas}

Segundo Dykes R., Enticknap S. (2012, p.2) os conhecimentos necessários para usar uma máquina retilínea automatizadas são:

- Informações detalhadas sobre as máquinas;

- Cuidados de manutenção;

- Sistemas de alimentadores e finalização;

- Sistema básico de CAM (computer);

- Explicações de tensão;

- Contagem de fios; 
- Passo a passo de tecimento do tecido de malha;

- Tecidos de malha simples, canelados, simulação de canelados e pontos fantasia;

- Utilização da ferramenta de transferência;

- Técnicas de confecção simples.

As agulhas dessas máquinas têm terminações com formas diferentes chamadas de agulhas baixas e agulhas altas. Os efeitos de layouts das agulhas vão aparecer, conforme o carrinho caminha nas agulhas e formam as malhas. Mudando o lugar das agulhas altas e baixas colocadas nas fronturas, é possível criar tecidos com diferentes desenhos. As agulhas são selecionadas na máquina, usando molas que ficam na parte de baixo das fronturas e empurram as agulhas para a ação. Quando as molas estão para baixo as agulhas estão fora de ação. As máquinas retilíneas atuais eletrônicas possuem muitos mecanismos de jogo de dispositivos: estes, por sua vez, regulam a tensão do fio e comandam o movimento das agulhas. Os mecanismos vão acionar ou não o levantamento das agulhas para laçar o fio e depois abaixar para formar a laçada. A seguir a figura com exemplo de agulhas em máquinas retilíneas eletrônicas com o sistema de molas.

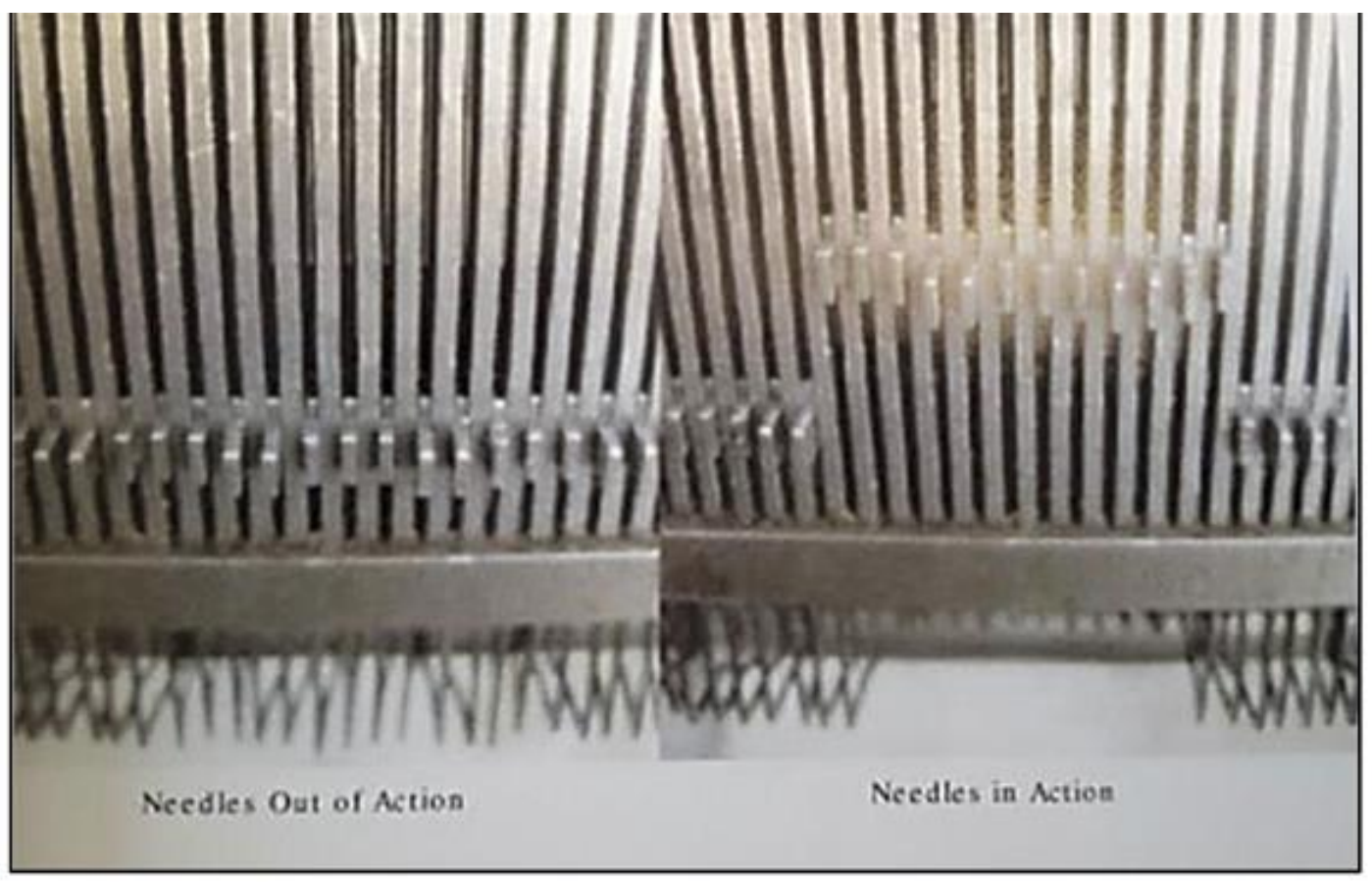

Figura 25 - Agulhas baixas e altas com acionamento de molas. Fonte: STOLL, 2012.

A figura a seguir, apresenta uma máquina retilínea eletrônica de última geração com 36 porta-fios e quatro sistemas. Ou seja, são quatro diferentes sistemas que resultam em 36 possibilidades de cores. 


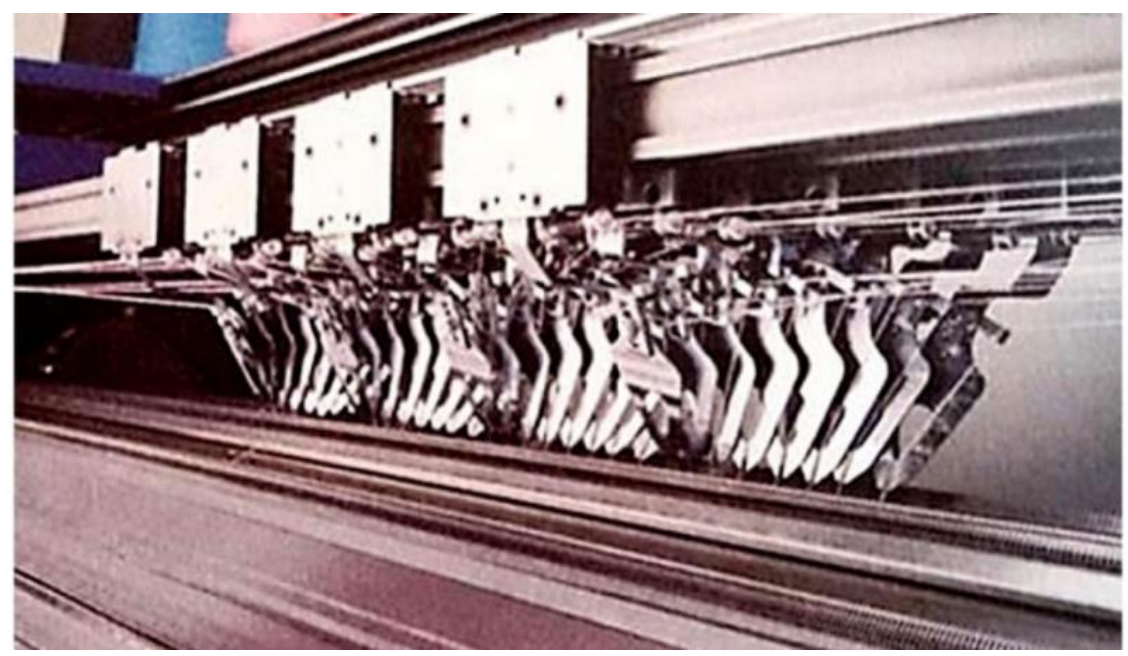

Figura 26 - Malharia Retilínea, a figura apresenta jogo de porta fios. Fonte: STOLL, 2012.

As máquinas retilíneas eletrônicas tem um porta-fio por cor e as atuais chegam a ter até 16 porta-fios. Dependendo do tipo de tecido mais complexo as máquinas usam vários sistemas que aumentam as possibilidades cromáticas e de misturas de cores.

\subsubsection{Principais Construções no VMMR}

São vários os tipos de construções desenvolvidos a partir da malharia retilínea conforme a tecnologia da máquina e a necessidade do produto a ser desenvolvido. Estes tecidos podem ser de uma finura bem rala quase transparente, até aos mais espessos e duplos com muita resistência usados também em outras áreas de produtos de fashion, decoração e médica. Dependendo do tipo de máquina retilínea (manuais, eletrônicas) podemos escolher uma construção de tecimento.

No Brasil observam-se quatro processos produtivos de malharia mais usuais:

A. Tecido corrido - Inicialmente é definida a largura do tecido conforme a necessidade do produto. O comprimento do tecido é definido de acordo com o número de produtos necessário para o corte da peça ou teste de modelagem (usado para decoração).

B. Painel reto com punho - O painel é um tecido de malha produzido na máquina retilínea, com um formato de medidas e com o acabamento de barra pronto, conforme a necessidade do produto. Cada vez que termina um painel e começa outro, são tecidas algumas carreiras de tricô que vai separar um painel do outro. Esse painel tem como característica acabamento na barra mais apertado para ter qualidade, não desfiar ou alargar. Sobre o painel serão colocadas as partes da modelagem para realização do 
corte. O painel muitas vezes é feito com diminuição de pontos para dar formas nas cavas. Nas máquinas retilíneas manuais são feitas com um instrumento chamado pulsão e nas máquinas com maior tecnologia é feito automaticamente.

C. Painel com modelagem pronta (calados) - As partes vão ser produzidas já com o formato do molde, com a tecnologia fully fashioned. Esta máquina tem programas de diminuição e acréscimos de pontos e número de carreiras que são capazes de definir o formato dos moldes. Algumas empresas por causa do modelo ou por motivo de tempo, usam produzir uma parte calada e a outra parte utilizando o molde para o corte. Quanto menos corte, a malha terá mais qualidade, e as costuras ficarão mais delicadas e bem acabadas.

D. Malha peça pronta - É fabricada nos teares retilíneos eletrônicos de última geração. São as máquinas mais utilizadas na produção de malhas de todos os tipos e exigências. Eles são capazes de tecer a peça já costurada lateralmente e com mangas e bolsos saindo de máquinas de peças de vestuário em malharia retilínea prontas para vestir. As máquinas de última geração já fazem a malha de peça pronta, dispensando as costuras. Essa tecnologia é chamada Wholegarment ou no Brasil "peça pronta".

Fully fashioned é um tipo de tecimento que tem uma técnica chamada de calado e diminuído. Essa técnica tece as partes prontas com diminuídos e aumentos necessários da modelagem sem a necessidade de corte. No sistema fully fashioned, a parte já é tecida no formato do molde, além de não desperdiçar matéria prima, com um descarte próximo a zero. No sistema de painéis, o descarte pode chegar até 30\%, pois os resíduos dos cortes das mangas e golas são descartados. No uso da técnica com calado no sistema fully fashioned, o molde é produzido e acabado com o formato da gola e cavas. Esses calados, ou pontos diminuídos, são feitos pela sobreposição de dois ou mais pontos no final da carreira de pontos, sendo que, quando pronto, não desfiam e não precisa ter acabamento com a máquina de overloque. A peça sai pronta, sem necessidade de repetir o trabalho e, como consequência, agregando mais valor ao produto.

A máquina de malharia retilínea computadorizada de peça pronta foi lançada no final dos anos 90, e chama-se tecnologia Wholegarment - oferecendo a malharia retilínea uma vantagem competitiva em velocidade, qualidade, design nas peças. Esta máquina tem programas que tecem diferentes formas como golas, cavas, sobreposições e outras possibilidades de criação que eliminam várias tarefas produtivas como costuras, acabamentos 
e muitos outros processos de arremate. A partir do ano 2000, foram lançadas as máquinas multigalgas. Elas têm mais de uma galga na mesma máquina, são mais resistentes e se apresentam com outros recursos de padronagens e modelagem diferente da peça pronta, que dependendo da escolha do produto, resulta em um retorno maior sobre e investimento.

Além do avanço da tecnologia dos teares eletrônicos, também foram desenvolvidas máquinas e programas nas áreas de estamparia, modelagem, corte do VMMR. As empresas a japonesa Shima Seiki e a alemã Stoll - estão cada vez mais aperfeiçoando este recurso, muito importante para os estilistas visualizarem a peça pronta antes mesmo de fazer o programa, tendo um ganho muito expressivo de tempo e ajustes da peça.

Como vemos na figura a seguir, o fabricante além de vender o equipamento também oferece um sistema integrado de desenvolvimento de produto. Um dos programas mais inovativos é a simulação em 3D do modelo no corpo.

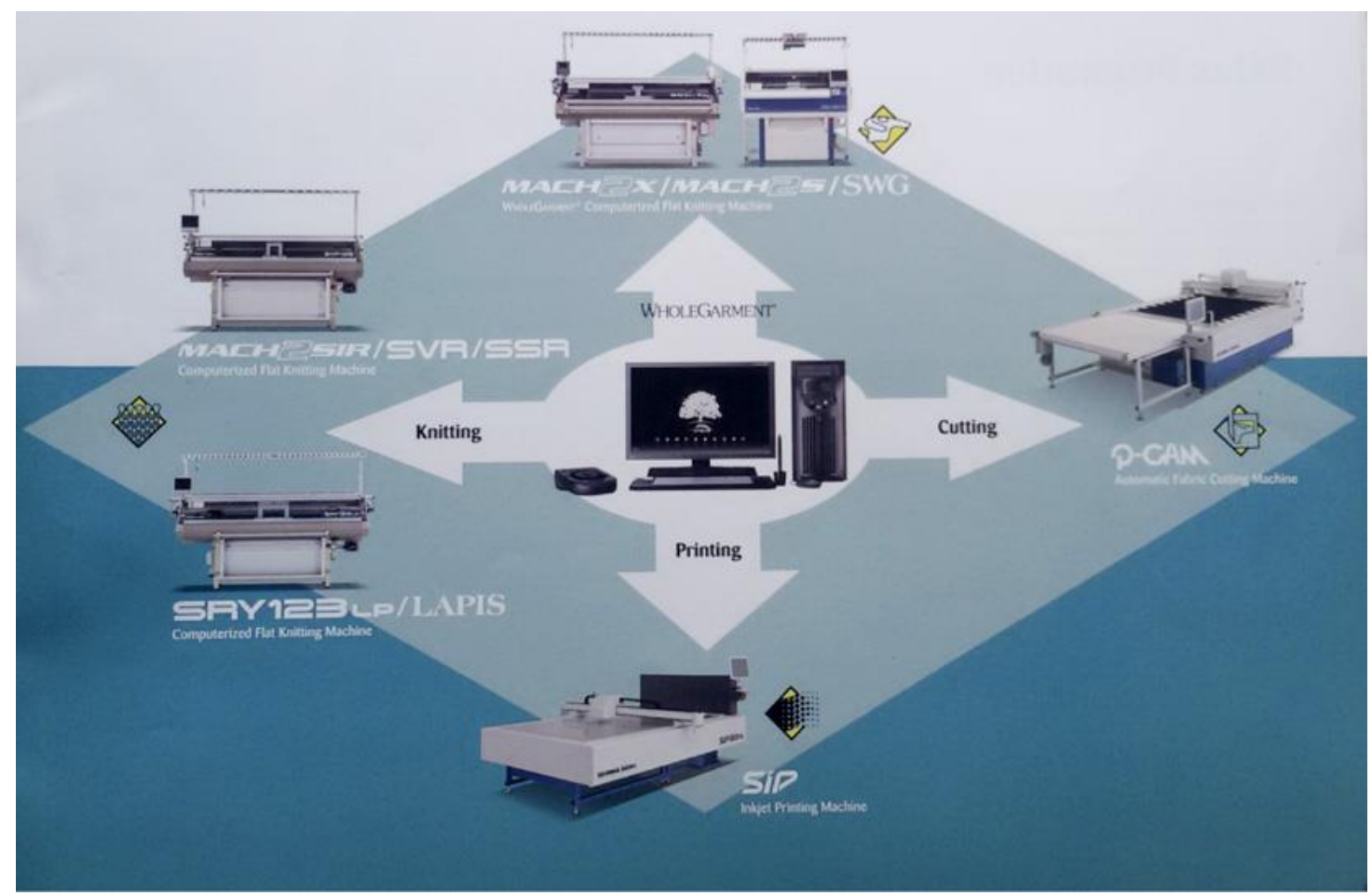

Figura 27 - Sistema integrado de Desenvolvimento de Produto da Shima Seiki. Fonte: Shima Seiki, 2012

Este sistema integra várias fases de desenvolvimento como: Tecimento do tecido em malha; peça pronta Wholegarment; em partes fully fashioned; corte de peças em malharia; estamparia de peças em malharia; sistema APEX 3 de design de produto. 
O fabricante de máquinas retilíneas Shima Seiki divide a modelagem de produto de Malharia em três processos:

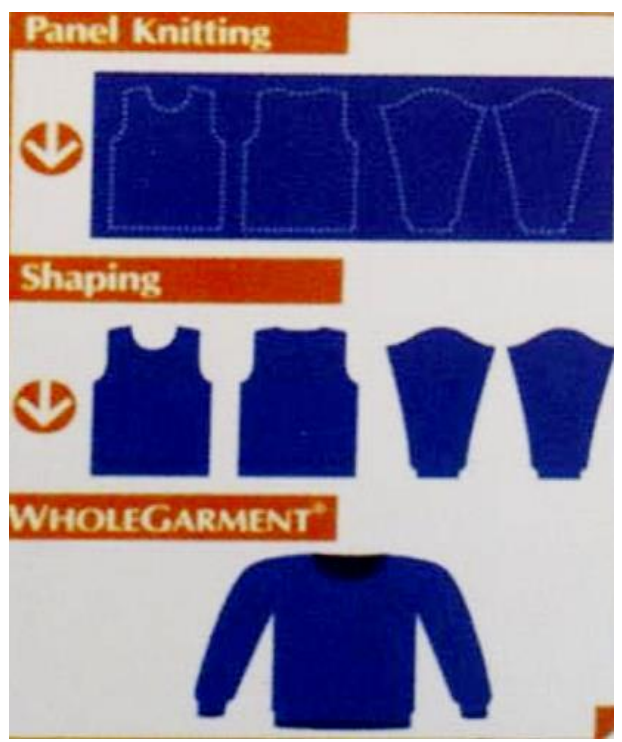

Figura 28 - Ilustração do processo de modelagem da fabricante Shima Seiki, software de modelagem. Fonte: Shima Seiki, 2010

- Painel com punho - Peças de vestuário criadas a partir de painéis com punhos. A modelagem é colocada sobre o material, cortada e costurada.

- Peça com modelagem pronta de máquina - Fully fashioned - Peça produzida com partes do vestuário modelada com calado e barra acabada - peça sai da máquina com os contornos da modelagem de barras, punhos, decote e laterais. Estes contornos são produzidos com teares que tem a tecnologia fully fashioned, que fazem a diminuição dos contornos das cavas e corpo automaticamente na execução da peça pela máquina. Na indústria com qualidade, os estilistas não cortam as peças depois de sair da máquina, quanto menos corte as peças tiverem, mais qualidade no produto.

- Wholegarment - Peça de vestuário é produzida inteira da máquina sem necessidade de corte e costura. Nas máquinas de última geração a peça vai direto para o acabamento, para acrescentar os detalhes finais de estilo, ou direto, para a passadoria e expedição. 


\subsection{Impacto ambiental e sustentabilidade no VMMR}

Nas pesquisas de tendência de design atuais buscam-se soluções nas áreas de desenvolvimento na fabricação, composição, propriedades, que não provoquem impacto no meio ambiente.

O que proporcionou o surgimento do conceito de sustentabilidade foi a escassez gerada pela falta de racionalidade no desmatamento causado pelas potências industriais europeias. No período que se seguiu à Revolução Industrial, essas indústrias utilizaram lenha para a produção industrial e para construir o transporte das mercadorias. Para gerir esta escassez, já em 1713, o alemão Carl Von Carlowitz utilizou a expressão nachhaltendes wirtschaften - administração sustentável, que os ingleses, por sua vez, traduziram como sustainable yield - produção sustentável.

A expressão desenvolvimento sustentável foi firmado no documento "Nosso Futuro Comum", também conhecido como Relatório Brundtland, coordenado pela primeira-ministra da Noruega, Gro Brundland, e publicado em 1987 com o apoio da Organização das Nações Unidas. Torna-se, então clássica a definição: desenvolvimento sustentável é usado para definir ações e atividades humanas que visam suprir as necessidades atuais dos seres humanos, sem comprometer o futuro das próximas gerações. Em seu sentido lógico, é a capacidade de manter o crescimento econômico, sem esgotar os recursos da natureza e sem poluir o meio ambiente, respeitando as limitações do planeta.

Para se obter um desenvolvimento sustentável, é necessário eficiência econômica, justiça social e prudência ecológica. Isso implica a necessidade de se multiplicarem as práticas sociais voltadas para a proteção ambiental, baseada no fortalecimento do direito ao acesso à informação sobre os problemas do planeta, e à educação ambiental em uma perspectiva integradora. E também, demanda aumentar o poder das iniciativas, pautadas pela premissa de que, um maior acesso à informação e transparência na administração dos problemas ambientais pode implicar em reorganização do poder e da autoridade no sentido de implementar políticas nacionais de proteção do meio ambiente natural e urbano (LAYRARGUES, 1997).

A noção de sustentabilidade está adquirindo um crescente espaço nos debates sobre a questão do desenvolvimento. $\mathrm{O}$ entendimento desse conceito inspira uma hegemonia ainda não estabelecida entre os diferentes discursos. Ao contrário dos conceitos analíticos que se 
voltam para a explicação do real, a noção de sustentabilidade está resignada à lógica das práticas: relaciona-se com os efeitos sociais desejados, a funções práticas para que o discurso seja viabilizado. Isso remete a processos de legitimação/deslegitimação de práticas e atores sociais. (ACSELRAD, 2013).

Hoje, a introdução de práticas ecologicamente corretas, são diretamente refletidas na imagem positiva que as empresas querem passar ao seu público. Cada vez com mais adaptações e investimento em novas técnicas, a busca pelas ações sustentáveis não são apenas optativas, mas passaram a ser uma exigência discreta de uma parcela de consumidores, que começou a enxergar as necessidades e problemas ambientais, além, é claro, das exigências internacionais presentes em todos os setores comerciais (SOUZA, 2002).

Exemplo de problema ambiental, consiste na geração de resíduos sólidos muito relevantes na indústria têxtil. "As etapas de maior impacto [são] a tecelagem e o corte do tecido, que geram um montante significativo de pelos (sobras do processo de fiação do fio), buchas (sobras dos fios nos processos de tecelagem) e retalhos (gerados no corte)" (MOURA et al., 2005 apud BERLIM, 2012). Apesar da quantidade significativa, esses resíduos podem ter oportunidades de comércio quando passam a ser transformados em enchimentos e estopas para uma série de produtos, tais como travesseiros e edredons, por exemplo (BERLIM, 2012).

Quando se fala de indústria têxtil, sabe-se que é enorme o volume de materiais utilizados, e consequentemente, a quantidade de resíduos sólidos gerados que também é muito grande. Determinados resíduos são extremamente agressivos ao meio ambiente; por isso, a CETESB e outros órgãos fiscalizam as empresas para averiguar o destino desses resíduos.

Outro comportamento que está sendo adotado e que tem trazido resultados no ramo da indústria têxtil é a utilização das sobras de tecidos em peças confeccionadas a partir de retalhos e a reciclagem em novos fios. É preciso, também, que a forma e o tamanho das partes dos moldes - que servem de base para a produção das roupas seja remodelados, visando a redução da geração de resíduos nesse ofício (FLETCHER; GROSE, 2011).

Ultimamente, as indústrias têm se preocupado em mostrar aos consumidores sua produção ecologicamente correta, adotando como medida os selos verdes. Indo um pouco mais além, as empresas começaram a ter o cuidado de implantar sistemas de gestão ambiental para conseguir a ISO 14000, que reflete o empenho da International Standardization Organization - que criou o SAGE - Strategic Advisory Group on Environment - que tem 
como objetivo um enfoque de normatização ambiental e certificação. Essa preocupação das empresas tem como meta principal apresentar o conceito de qualidade ambiental, de modo a competir com o mercado externo e ainda conscientizando o mercado interno que preço não é o único fator que importa.

Uma medida que vem sendo cada vez mais considerada e colocada em pauta é a questão da utilização de fibras biodegradáveis. Com essas fibras, as roupas quando chegam ao fim do seu ciclo de vida, podem biodegradar sem causar danos ao meio ambiente. Tal fato tem sido importante para minimizar a geração de resíduos têxteis e indumentários e ainda diminuir o volume de lixo reduzindo seu despejo em aterros sanitários. É importante ressaltar nesse contexto, que os impactos no meio ambiente variam de uma fibra para outra, ou considerando diferentes tecidos e desenhos de peças de vestuário (FLETCHER; GROSE, 2011).

Todos os anos, os lanifícios lançam fios de acordo com novas tecnologias e tendências que atendam às necessidades dos consumidores. Hoje a sustentabilidade também é valorizada como tendência e está na moda. Como foi referido a Pitti Filati, a principal feira internacional de lançamentos de fios, preocupa-se em apresentar os fios coloridos com pigmentos naturais como folhas, pedras, e outros elementos que, quando decompostos não agridam a natureza. As técnicas atuais de tingimento estão evoluindo e, o custo desse processo, esta cada vez mais acessível. As fibras naturais estão sendo mais usadas como moda, porém seu custo elevado é um fator impactante no custo final do produto.

Comparada a outros segmentos industriais, o setor industrial de malharia retilínea é pouco poluente em relação a resíduos sólidos e nível de ruído. Os resíduos são, basicamente, fragmentados de fios e tecidos de malha, que podem ser reaproveitados por outras empresas na confecção de cobertores, carpetes e tapetes (ROOS, p. 29).

Observam-se três situações de tecimento que geram diferentes quantidades de descarte: malha corrida e painel com punho, painel com punho e calado. Nestes tecimentos sempre é necessário cortar uma quantidade de tecido que gera descarte para chegar e finalizar a modelagem correta da peça. No caso de descarte de restos de fios e malhas recortadas deveriam ser separadas de acordo com a composição para serem reaproveitadas. Os retalhos ou peças com defeito podem ser desmanchados e o fio aproveitado, mas geram um custo de mão de obra que nem sempre está disponível. 
As máquinas de última geração de retilínea tem uma produção com um descarte praticamente zero com as novas tecnologias (fully fashioned, e wholergarment). Os descartes de fios e tecidos são cada vez menores, o maior problema atualmente é o descarte das peças usadas.

Essas soluções remetem ao conceito de sustentabilidade ambiental que está presente em pesquisa na área de coloração dos fios, materiais com pigmentos orgânicos e minerais. A área de coloração, por exemplo, é uma das principais fontes de poluição do meio ambiente. As novidades de fios em malharia retilínea são semestralmente expostas nas feiras internacionais como Pitti Filati na Itália, e em outras, ampliando as possibilidades criativas, com a tendência de pesquisas com preocupação em desenvolvimento de pigmentos e fibras que não poluam a natureza.

Os corantes naturais causam menos impacto ao meio ambiente, porém até poucos anos atrás, eram difíceis de fixar as cores, com os custos altos. As técnicas atuais de tingimento estão evoluindo e o custo desse processo está cada vez mais acessível. A pesquisa em coloração com pigmentos naturais atualmente oferece uma ampla gama de tonalidades de cores firmes com uma melhora na qualidade de fixação e toque. Em entrevista com os fabricantes na feira de 2011, observou-se um percentual de $20 \%$ a mais no custo. Esta diferença é baixa no total do custo final da peça pronta e estes materiais estão cada vez mais sendo usados comercialmente.

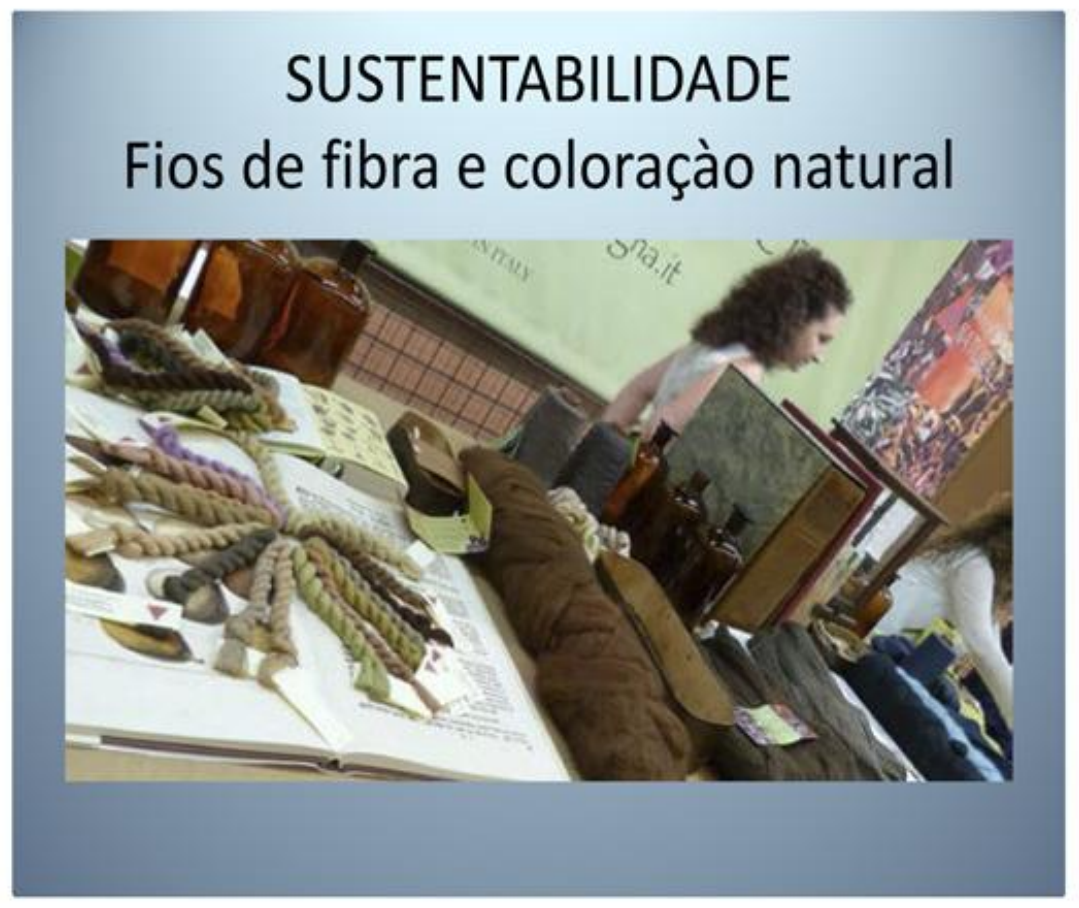

Figura 29 - Mostra de fios com coloração de pigmentos com corantes vegetais. Fonte: Pitti Filati, 2011. 
Com esse entendimento a Feira de Moda Pitti Filati se preocupa em apresentar os fios coloridos com pigmentos naturais como folhas, pedras, e outros elementos que quando decompostos não agridam a natureza.

As principais etapas que geram poluição no processo produtivo são:

Fiação - Na fiação os principais geradores de poluição são os níveis de ruído, o calor provenientes das máquinas, e o pó composto por partículas resultantes dos processos de fiação das fibras. A fase mais critica é no tingimento e beneficiamento na produção dos fios. Esse trabalho emprega maior número de substâncias químicas acentuando o risco de gerar resíduos poluidores da água e ar. Além dos corantes, aplica-se um lubrificante no fio que é considerado grande agressor do meio ambiente.

Desenvolvimento de produto - Na etapa de criação do produto, são feitos muitos testes de modelagem e regulagens de tecidos, resultando em muitas amostras descartadas. No processo manual e artesanal usado ainda por algumas malharias, a tendência é o reaproveitamento com o desmanche do tecido e tecimento de uma nova amostra. Nas máquinas mais atuais e desenvolvidas com tecnologias de ponta, as amostras são descartadas e sucateadas, porém, quando a amostra é aprovada, vai para o banco de dados e pode-se repetir esta programação por muitas vezes. Esse sistema avança e torna-se no decorrer do tempo muito mais eficaz e economicamente produtivo.

Fabricação do tecido - A fabricação dos tecidos de malha geram os mesmos impactos observados na fiação.

Fabricação e confecção do produto - Em termos de resíduos, o corte das peças e seus acabamentos são problemas muito questionados e ainda sem solução. A esse problema acrescentam-se os descartes dos cortes dos fios e tecidos. Nas micro e pequenas empresas a preocupação inexiste; nas grandes empresas, os descartes normalmente são vendidos a quilo, para um reaproveitamento.

Beneficiamento - Alguns processos de confecção utilizam estamparia ou tinturaria como um modo de diferenciação do produto. Este processo utiliza produtos químicos e de lavagem obviamente nocivos ao meio ambiente. É muito importante o posterior tratamento da água que foi utilizada nesse processo.

Embalagem - As embalagens são normalmente recicladas. 
A indústria da moda enfrenta uma nova realidade, que leva em conta a responsabilidade socioambiental. Faz-se necessário a adequação nos processos produtivos com ações conscientes dos riscos ambientais, resultantes dos descartes de têxteis no planeta. Assim, é possível ter um aumento da produção industrial conjugada ao menor gasto de insumos, matérias-primas e redução da geração de poluentes.

Dentre as medidas a serem atingidas na implantação de procedimentos operacionais para reduzir o uso de produtos químicos (CETESB; SINDITÊXTIL, 2009), destacam-se:

- Redução do consumo de água;

- Recuperação e reutilização de água;

- Redução do consumo de energia;

- Possibilidade de lavagem a seco;

- Diminuição de emissões de substâncias odoríferas;

- Minimizar a geração de ruídos e vibrações;

- Recuperação de goma, soda cáustica;

- Reutilização ou reciclagem de resíduos gerados pelas embalagens.

$\mathrm{Na}$ etapa do desenvolvimento de produto de VMMR, deve-se estudar minuciosamente o fator de risco ambiental, a fim de avaliar seus efeitos ao longo da produção, seu uso e descarte. É preciso considerar que os tecidos inutilizados por defeitos de fabricação devem ser recuperados, aproveitados e incorporados ao processo produtivo. No âmbito do mercado final, o vendedor deverá orientar o consumidor de como tratar e utilizar a roupa, com vista a sua maior durabilidade e tempo de uso. Esse procedimento evita o descarte direto ao lixo, pode ser posto a venda a terceiros ou ser doado às entidades beneficentes que aceitam o vestuário em boa qualidade de uso. 


\section{Desenvolvimento de Produto de Vestuário em Moda na Malharia Retilínea}

O desenvolvimento de produto VMMR, também denominado tricô, apresenta-se de várias formas e métodos, conforme a necessidade e repertório do profissional envolvido e do sistema de trabalho da equipe de desenvolvimento de produto. $\mathrm{O}$ estudo aprofundado em referências históricas do design, métodos de engenharia, estudo do comportamento humano e manifestações artísticas são fontes de inspiração para o desenvolvimento sustentável de novos produtos. A palavra inglesa knit deriva do termo knot (inglês) que significa nó em português.

A origem da malharia retilínea vem da técnica de entrelaçamento do fio com a ajuda de delgados e pontiagudos estiletes de ossos ou madeira. Essa técnica artesanal chamada tricô veio dos povos do Egito Antigo. Nas regiões onde a lã era abundante, as mulheres produziam meias e cachecóis para protegerem seus filhos e maridos. Há indícios de que as pessoas já teciam, usando apenas os dedos, em 1000 A.C. (SISSONS, 2010, p. 11).

A história do vestuário caminha com a história do homem. Desde o início a humanidade, se serviu das fibras que a natureza colocou a disposição e, entrelaçando as fibras têxteis, inventou o tecido. Cada fibra contendo suas características particulares de uniformidade, elasticidade e resistência, submetidos a tratamentos particulares. (Textile Vivant, www.sustainability-lab.net, 2014 p.66).

No desenvolvimento de produto de moda e design de VMMR, os estilistas utilizam técnicas e processos de criação de acordo com suas vivências e repertórios. Durante este trabalho, descrevo alguns processos, porém as possibilidades são infinitas. O estilista busca sempre um diferencial, seja conceitual dentro das tendências atuais e na tecnologia de processos produtivos e materiais.

A mais antiga peça produzida com essa técnica de manufatura de tecer com agulhas manuais de malharia foi um tipo de meia. Meias foram encontradas no terceiro século da era Romano-Egípcia, entre os séculos XIV e XI A.C. O tecer a mão era comum na Europa medieval; e a produção de luvas, chapéus e meias era uma indústria importante. Na figura a seguir, observa-se uma técnica de tecer a mão sem costura. 


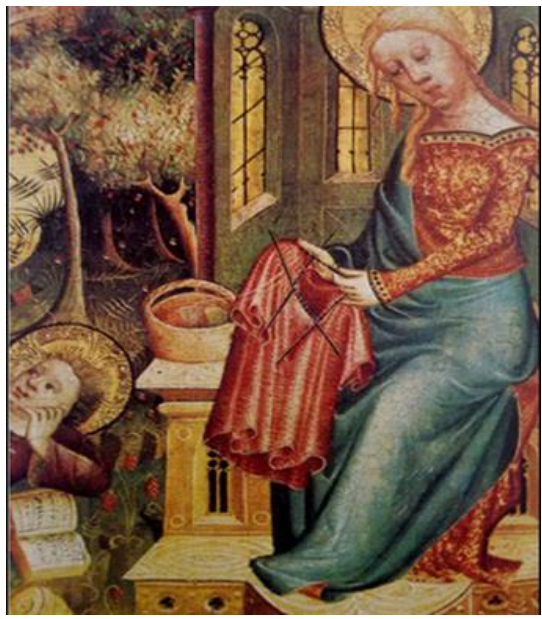

Figura 30 - Visit of the Angel, conhecida como Knitting Madonna, Mestre Bertram de Minden, 1400. Fonte: SISSONS, 2010, p. 10.

As primeiras máquinas de malharia retilínea produziam tecidos muito parecidos com os feitos artesanalmente com duas agulhas pelas mãos das antigas mulheres. Na Inglaterra, seu desenvolvimento teve início em 1589 com a invenção do tear manual de malha por trama para meias, produzido pelo clérigo Willian Lee (1563-1614).

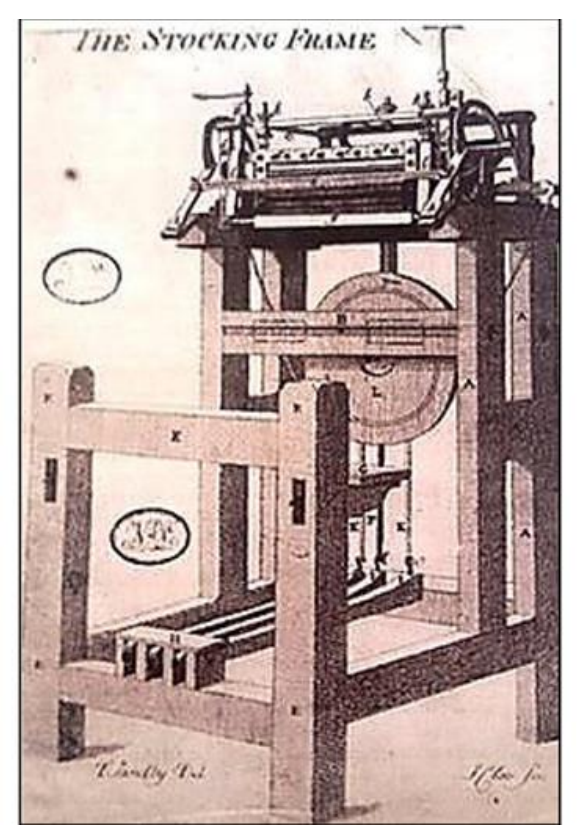

Figura 31 - Tear de pedal inventado por William Lee em 1589. Fonte: Sissons, 2010.

As tecnologias foram evoluindo no decorrer do tempo, mas sem muitos registros. A primeira máquina retilínea que se tem catalogada foi em 1740. Em 1863, o americano Isaac Wixom Lamb patenteou o tear de bancadas em V que eram máquinas de tricotar domésticas, cuja simplicidade permitia a qualquer pessoa produzir suas próprias peças e se estendia desde 
grandes empresas até a produção caseira. O sistema de construção da malha na máquina retilínea é basicamente o mesmo no sistema eletrônico ou manual. Durante o século XX, as técnicas foram se aprimorando e nas últimas três décadas a malharia evoluiu muito com as novas tecnologias da informática e construção de matéria prima (MATKOVIC, 2010).

O constante desenvolvimento e estudo da construção das máquinas retilíneas foram obtidos depois de muitos estudos e testes de adaptação entre os recursos mecânicos, eletrônicos e informacionais. Foram muitos anos para aprimorar as técnicas e conseguir um tecido uniforme, sem pontos caídos e fios quebrados, que resultam em defeitos nas malhas. As agulhas foram diminuindo suas espessuras e mudando sua forma. As bases das máquinas também foram mudando as ranhuras por onde passam as agulhas.

Hoje, o Vestuário de Moda na Malharia Retilínea (VMMR), é um seguimento que tende a crescer principalmente pelos recursos tecnológicos desenvolvidos nos últimos anos. A seguir, são descritos esses avanços e suas possibilidades criativas, no decorrer da história do produto de malha retilínea nas máquinas retilíneas, também chamadas de V-bed flat knittig.

A evolução do vestuário de malharia retilínea ocorre com o desenvolvimento das tecnologias de máquinas por parte dos principais fabricantes de máquinas retilínea. Entre eles destacam-se a empresa Stoll na Alemanha e a empresa Shima Seiki, no Japão. As empresas pesquisam diferentes tecnologias com suas evoluções, expostas sistematicamente nas feiras do mercado têxtil. São mínimas as diferenças de resultado nas tecnologias das duas empresas quanto à produção e criação de produtos de VMMR. Ambas as empresas desenvolveram sistemas padrão de geração de CAD diretamente ligado à produção da máquina. O desenvolvimento de controle eletrônico individual, com seleção das agulhas por parte das empresas, também resultou na facilidade de fabricação de complexos e sofisticados padrões e modelagem, tarefa que anteriormente envolvia um processo manual, demorado e com alto custo (FOGG, 2010).

A partir do ano 2000, os teares de malharia retilínea começaram a ser construídos com mais de uma finura na mesma máquina denominada máquina multigalga. Essas máquinas têm dispositivos com maior flexibilidade na disposição das agulhas e tensão que conseguem produzir malhas, por exemplo, com finuras ou galgas cinco, sete e oito, na mesma máquina. Com esse avanço, as malharias tiveram um ganho na produção, pois tem condições de produzir diferentes espessuras de tecidos na mesma máquina, atendendo a demanda da moda para as estações mais frias e mais quentes. Essa flexibilidade resultou em um ganho de 
produção nos produtos com padronagens muito elaboradas, com recursos de máquina para fazer uma diversidade de pontos e cores.

Outro avanço muito importante nas máquinas retilíneas, apresentada no início da década de 2000, foi a máquina de peça pronta, com tecnologia que produz uma peça de vestuário sem costuras nas laterais ou nas cavas. Essas máquinas evitam o desperdício de matéria prima, custos de costura e acabamentos, tornando o produto de VMMR mais sustentável (FOGG, 2010).

Essas duas tecnologias (multigalga e peça pronta), apesar de terem sido amplamente aprovadas e usadas, foram questionadas até o começo desta década por apresentarem uma produção mais lenta. Porém já foram lançados modelos com mecanismos que alcançam, ou até ultrapassam, a velocidade de produção da máquina convencional.

O uso dessa nova geração de equipamentos cresce rapidamente e os designers estão começando a considerar a tecnologia como uma ferramenta de recurso criativo, pois apresentam características estéticas únicas, a partir da sensação de vestir peças sem costuras.

Novos recursos desenvolvidos permitiram novas variações de produtos, conforme figura a seguir. $\mathrm{O}$ que se converteu em vendas aos produtores, ampliando a adesão das máquinas CMS (Control Mind Sistem). Na figura a seguir, alguns exemplos de pontos, texturas e desenhos desenvolvidos nas máquinas de VMMR.
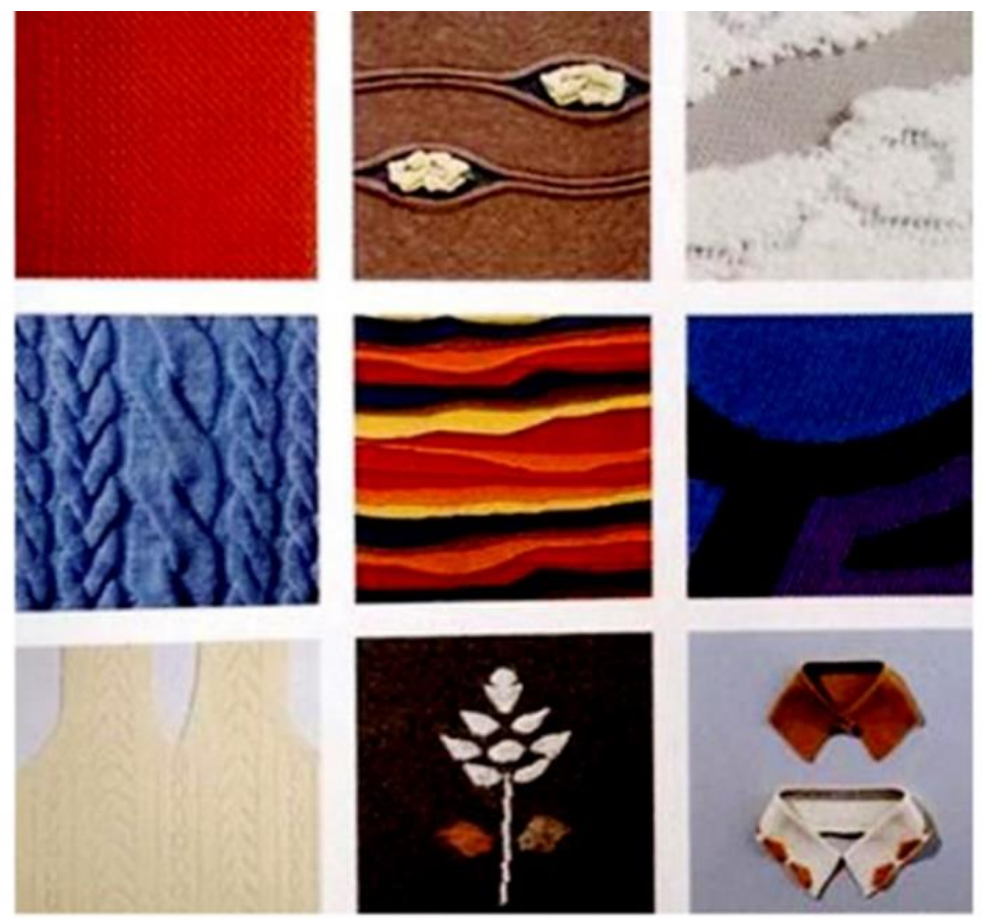

Figura 32 - Desenhos diferenciados com recursos de CMS em máquinas retilíneas. Fonte: STOLL 2008, P.113 


\subsection{Processos de desenvolvimento de produto no VMMR}

No processo de desenvolvimento de produto da malharia retilínea é necessário detalhar minuciosamente o produto com todas as especificações técnicas, indicar o recurso a ser usado, matérias primas, pontos, medidas, a fim de elaborar os documentos do projeto. Além da utilização dos recursos técnicos de programação, as amostras também são modificadas com aplicação manual de novos elementos visuais, tais como fitas, drapejados conseguidos com a utilização de elásticos, bordados, pintura.

Godart (2010, p. 48), apud Gereffi (2010) a cadeia de valor compõe-se, segundo Jennifer Bair e de nove elementos ou etapas:

1. A criação dos têxteis a partir de matérias primas;

2. A preparação;

3. O design e o desenvolvimento de produtos;

4. Corte da peça;

5. A montagem;

6. A lavagem e o acabamento;

7. A distribuição para os comerciantes;

8. O marketing;

9. A venda para os particulares.

Os autores atestam que apenas três dessas etapas permanecem preservadas como domínio exclusivo das casas de moda dos países industrializados e não foram deslocadas para subcontratados em países com baixos salários, design, o marketing e a distribuição para particulares.

No processo de criação dos produtos de VMMR a escolha do fio define-se a sua qualidade e consequentemente o custo final. Em segundo lugar fica o tempo de tecimento e acabamento das peças de malhas. Dependendo do custo da matéria prima vai resultar em diferentes parâmetros de cálculo de preço final do produto. Por exemplo, em malhas de custo baixo de matéria primas, o fator mais importante no custo total é o custo da hora máquina. Isso porque, esse custo de troca de modelo quanto à troca de cor, influenciam no custo total do produto. Nas peças de luxo o custo do modelo pode triplicar e ainda ser customizado com adereços e misturas com outras matérias que vão onerar ainda mais o produto. 


\subsection{O Desenvolvimento de Produto e seus Processos Criativos em VMMR.}

Para iniciar este subitem, descrevo alguns pontos de vista de Estilista e de diferentes conceitos profissionais na área de criação e desenvolvimento de produto.

As coleções são resultado de um processo criativo que se inicia com uma ideia. Esse processo criativo começa com uma pesquisa, que é estabelecida individualmente com uma equipe e com a ajuda de estudios de tendências.

No processo criativo, diz Faerm (2010) "é necessário o conhecimento dos tecidos e dos princípios cromáticos que possam reforçar a mensagem que queremos comunicar, isto é uma visão madura da Moda." E o autor discorre sobre a influência que um estilista imprime na coleção de modelos de uma empresa de vestuário de moda: "A análise da estratégia comercial e dos estudos do Marketing dos clientes demonstrará como uma coleção será elaborada a partir de um foco no público de referência, transformando o produto e sua marca em um verdadeiro objeto de desejo".

O design opera a associação desses dois níveis atribuindo forma material a conceitos intelectuais. Trata-se, portanto de uma atividade que gera projetos no sentido, esboços ou modelos. Considerando pesquisas em diversas áreas de expressão em criação de moda, observa-se que existem vários caminhos para desenvolver uma coleção (MENDES, 2010). Os designers de moda necessitam estudar as características dos fios e suas possibilidades de tecimento. Segundo Neves (2010, p. 82), “os sistemas computacionais aplicados ao design do produto de malha possibilitam alternativas projectuais para manipulação gráfica de imagem". Os avanços na tecnologia possibilitam novas formas de criação em malharia e têxteis de malha.

Designers estão explorando as qualidades únicas que a malharia tem a oferecer, derrubando fronteiras com fios e materiais incomuns e brincando com a escala. Há uma interação natural entre arte, design e novas tecnologias (SISSONS, 2010, p. 10).

Como descreve Avelar em "As tecnologias e a moda" (2009, p. 23).

"Esse campo se vale das tecnologias, especialmente as digitais, tanto na pesquisa conceitual (mais experimental) como no desenvolvimento de elementos objetivos, por exemplo, os tecidos inteligentes e os wearable computers. As tecnologias tornam-se protagonistas, promovendo mudanças nítidas nos trabalhos recentes de estilistas das mais diversas formações". 
Para Neves (2010), “projetar as superfícies e as texturas no produto têxtil são etapas estratégicas, pois através desses dois elementos pode-se narrar de forma expressiva e materializar detalhes da coleção". Os materiais fibras, fios, e os tecidos estão se tornando cada vez mais confortáveis, eles dão liberdade de movimento, transpira e respira de acordo com a temperatura, este conforto envolve e dá prazer em um dia de stress, trânsito, e mudanças de temperatura. Continua Neves, "como o tecido de malha é composto por pontos e estruturas que integram a base do produto, a seleção do fio e a sua representação, bem como suas medições com os atores deste evento, mostra-se fundamental”.

Os programas de softwear de última geração tem tradução simultânea da linguagem simbólica com o real do produto pronto. Estas representações simbólicas foram introduzidas no passado e tornaram-se base de programação das máquinas retilíneas. As novas técnicas de digitalização permitem visualizar em tempo real duas telas de computador mostrando a linguagem de programação e o efeito da imagem real dos pontos em outra tela.

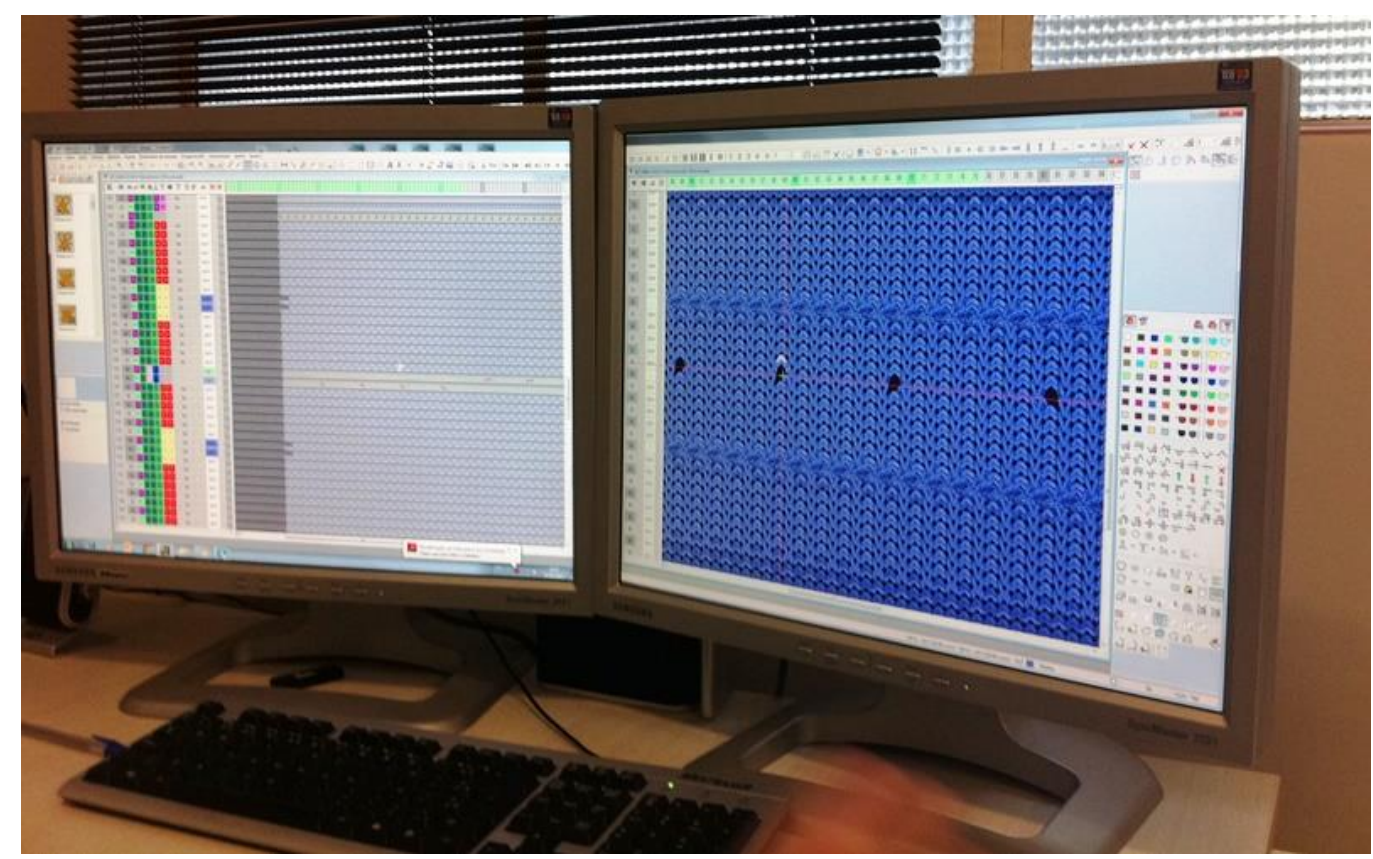

Figura 33 - Visualização da linguagem de informática e da real. Fonte: Malharia Gita, 2014.

Para tornar-se um estilista prolífico e de sucesso, a coleta de material a partir do qual se inspirar desempenha um papel proeminente. Deve constituir uma base sólida tanto para a qualidade e para a quantidade. Os critérios de pesquisa e o modo de utilização das informações são escolhas pessoais. 
Usualmente o método mais eficaz consiste na experimentação e em estar aberto às novas experiências, a fim de entender o que estimula uma maior criatividade. A street culture, os museus e as galerias de arte, a arquitetura, a história dos costumes, a tecnologia, as culturas mais distantes da nossa, as histórias recontadas da literatura ao cinema. As ideias são infinitas e esperam serem desfrutadas pelo design de moda. Para o estilista desenvolver uma visão estética única ele deve adquirir familiaridade com as cores, motivos, tramas, gramaturas e siluetas a fim de dar realce a certa atmosfera, comercializar o melhor de sua coleção, conservar a coesão interna e chamar a atenção do público. (Godart, 2010, p. 30).

A pesquisa vai sendo desenvolvida com ideias, materiais, imagens, objetos, territórios, e muitas mais opções criativas. O processo mais usado é o painel imagético ou ambiência, porém, a criatividade do estilista passa pela história de cada um, experiências e trabalho sobre determinada técnica manual e mental. Conforme apresentado pela figura a seguir.

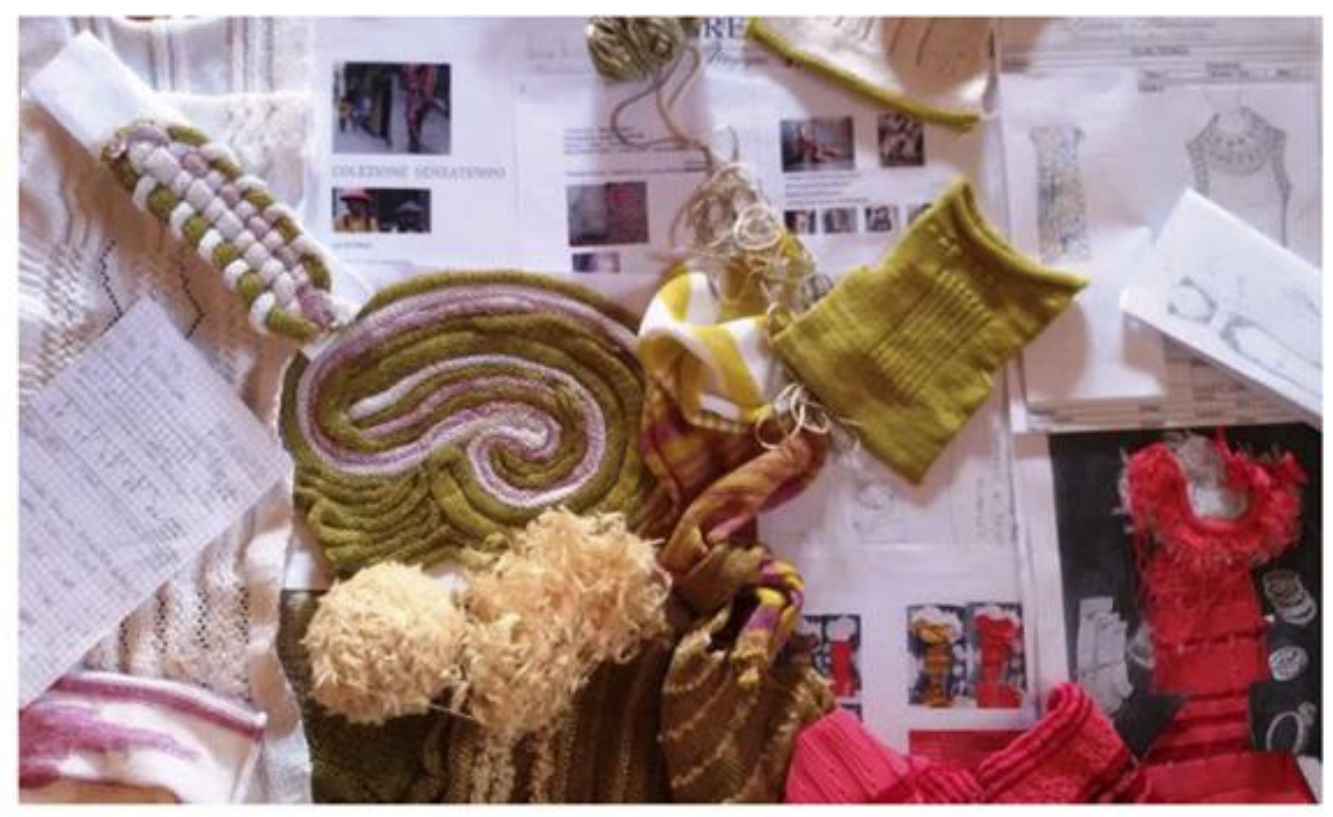

Figura 34 - Painel de imagens, inspiraçoes para coleção. Fonte: Laura Piccinini, IUAV, 2015.

Segundo Avelar (2009, p. 21), “a análise de sua organização atual e das criações - que oscilam entre coleções para o
consumo imediato e aquelas mais ligadas a linguagens menos óbvias - as novas
tecnologias surgem como elementos definidores da moda: novas formas de produção e
distribuição, favorecendo criações para consumo imediato: novos tipos de tecidos e de
construções sobre o corpo, utilizando aparatos tecnológicos: novos paradigmas, vistos 
em criações de estilistas que tendem a enfatizar o conceito, menos digeríveis ou mais distantes de determinados padrões".

Avelar (2009, p. 93) "Cada vez mais se formam "exércitos" de pesquisadores, que se espalham pelo planeta munido com suas câmeras digitais. São contratados por escritórios de estilo ou de marcas e captam mínimos detalhes diferenciadores".

O processo de desenvolvimento de produtos de moda, em geral, se inicia com um estudo de estilos e criação de conceitos conectados a uma proposta de coleção, que se segue de uma série de atividades até a aprovação final das peças (pilotos aprovadas, bem como seus moldes, padrões, cores e materiais).

Segundo Carvalhinha (2007, p. 20),

"o processo parte dessa concepção geral de coleção, passa pela escolha de materiais e desenho de modelos (etapas paralelas), e segue pelo afunilamento do processo criativo, convergindo na elaboração dos protótipos até sua aprovação. A fase de design de moda mais conceitual vai dando espaço ao desenvolvimento de produto, que deve ser viável para produção e comercialização".

A ideia principal é elaborada e desenhada de acordo com os recursos tecnológicos e materiais da empresa, e guia para a geração de produtos com um significado consistente dentro do tema proposto, conforme figura a seguir:
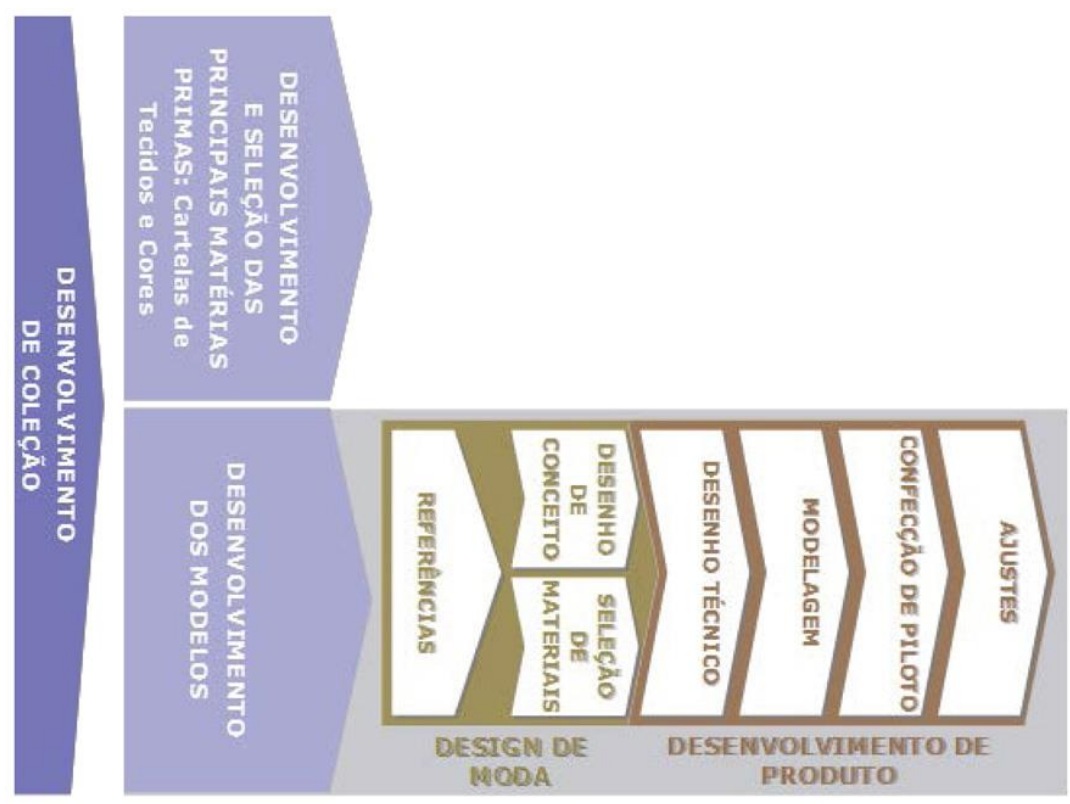

Figura 35 - Fonte: Carvalhinha (2010).

A necessidade de conhecer o produto, as possibilidades técnicas e produtivas das máquinas, as composições das fibras e fios, aprofundam as potencialidades e exige uma 
programação de sistemas para a elaboração dos desenhos no VMMR. Todos os produtos compreendidos em software vêm considerando instrumentos que fazem funcionar a máquina. $\mathrm{Na}$ realidade são as enormes pesquisas; no processo produtivo; em marketing; em planificações de gestão das produções; da memória e arquivo histórico das peças piloto aprovadas pelas produções mais vendidas; qualidades gerais do produto; serviço fornecido ao cliente final (TRAINI, C., 2012, p. 124, tradução nossa). O programa começa trabalhando com os primeiros tecimentos, e testes de qualidade são executados. Depois de aprovado, o modelo é ampliado por tamanho no programa de modelagem. Na figura a seguir a demonstração de um programa de estilo e modelagem desenvolvido por empresa fabricante de máquina retilínea eletrônica
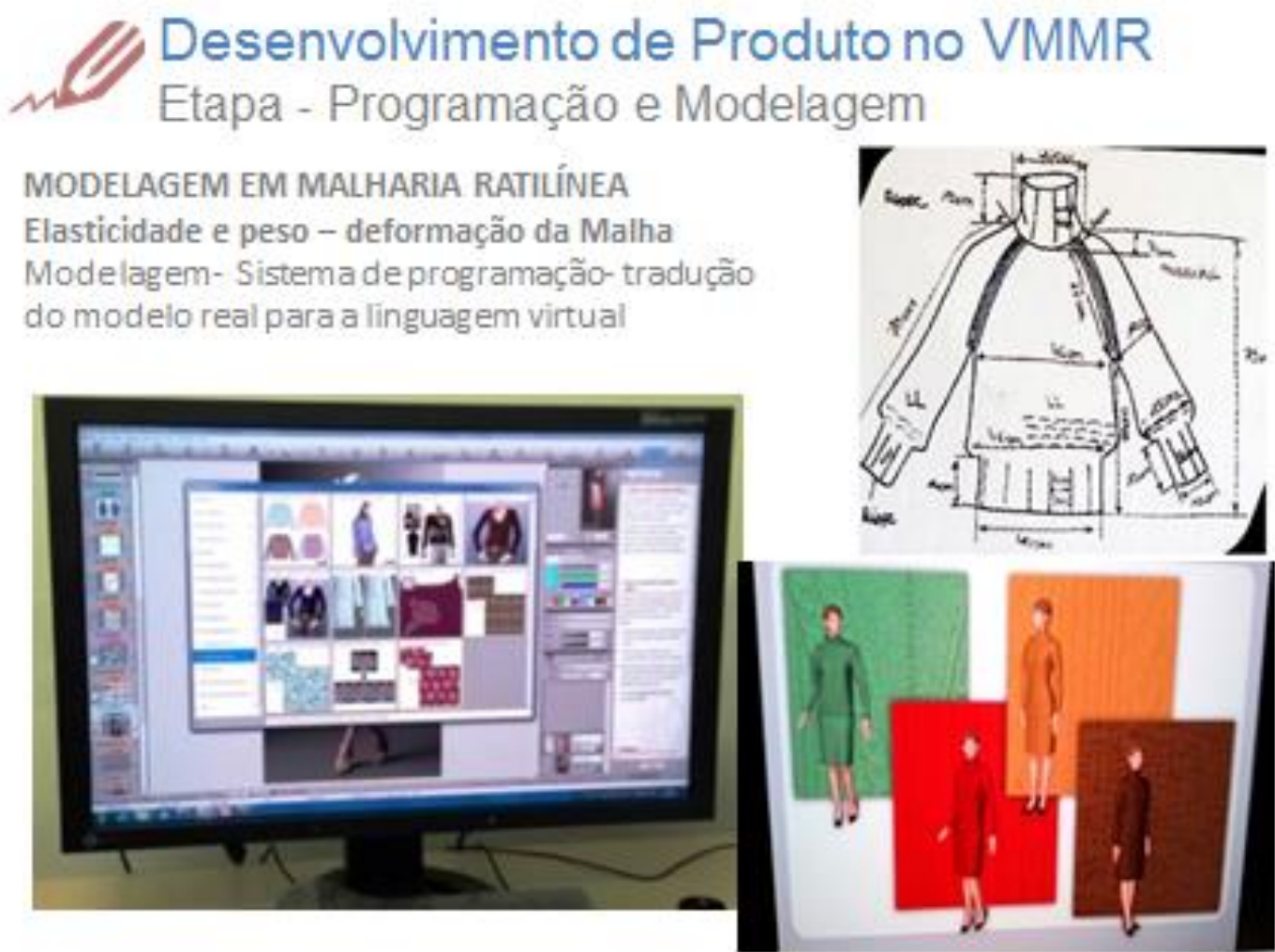

Fig. 36 - Modelagem detalhada e escolha de tecido e textura, peso e ponto. Fonte: STOLL, 2010.

Na malharia, o desenvolvimento de produto de VMMR (modelo) parte da textura dos fios e pontos, formando a construção do tecido. Na maioria dos produtos de VMMR a construção é iniciada em painéis com arremate (barras e punhos), dispensando, com isso, a bainha. O ponto do tecido de malha é o fator determinante do modelo e, consequentemente, 
da modelagem, pois é a partir da textura, elasticidade e caimento da malha, ou o prévio conhecimento dos seus efeitos, que poderemos traçar o molde para concluir a interpretação do modelo (BREHN, 1997, p. 2).

Os fios são cuidadosamente escolhidos pelos estilistas com base em testes, mas a experiência do estilista pode encurtar o caminho. Por exemplo, um fio para tecer um produto de moda transparente de verão precisa de uma pesquisa mais apurada, já um produto com um fio liso mais usual, que cobre todo o corpo para inverno, é mais fácil de pesquisar.

Os fabricantes de fios oferecem as especificações e testes de qualidade e usos destes fios, que devem ser selecionados de acordo com as diferentes galgas ou finuras.

Para cada modelo existe um desenho técnico com as medidas exatas das dimensões do modelo. Este desenho deve conter as informações de máquina, tais como galga, fios, modelagem, pontos e acabamentos. O Eneas Shaper, da empresa Stoll, como mostra a figura a seguir o programa é utilizado para fazer a criação dos formatos e modelagens. A seguir um desenho feito pelo estilista com detalhes de medidas e detalhes para ser interpretado pelo programador.
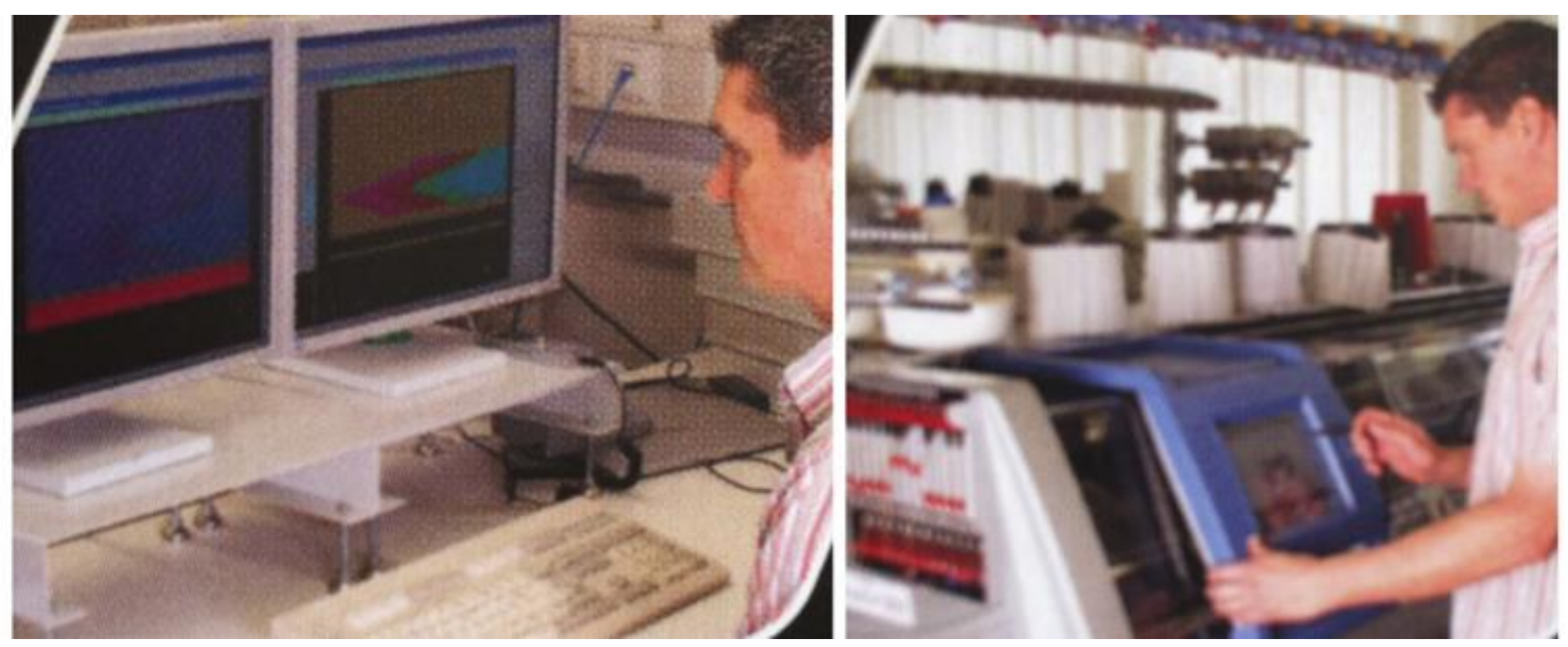

Figura 37 - Programação com tradução simultânea de linguagem real e simbólica de estilo e modelagem na máquina eletrônica, operador de máquina inserindo o programa. Fonte: Stoll, 2010.

Quando todos os envolvidos estão de acordo com o modelo, ele é programado pelo computador e o primeiro protótipo pode ser manufaturado. São feitas provas de modelagem para aprovação e os modelos vão sofrendo ajustes até a provação final. 


\subsection{Capacitação do profissional de desenvolvimento de produto de VMMR}

A importância do uso do produto de VMMR deve-se ao fato de que, nos tempos atuais, há uma busca pelo conforto e por um estilo individual obtido através da mistura de estilos diversificados. É uma versatilidade que agrega importante qualidade para a moda; porém, torna o desenvolvimento de produtos mais complexo. Por isso, para estudá-lo, será necessário integrar conhecimentos de diversas áreas, tais como, áreas de design, desenvolvimento de produto e programação da máquina. Como consequência, há necessidade de envolver uma equipe multidisciplinar.

Neste cenário, Faerm (2010 p. 68), esclarece "Os estilistas devem encontrar o justo equilíbrio entre o desejo de inovação e a capacidade de unir a forma aos materiais para dar vida aos protótipos a fim de maximizar as características de seu valor".

Para tornar-se um estilista completo no VMMR, é necessário ter uma ampla gama de conceitos fundamentais das várias técnicas de desenho para construir um arquivo visível e eficaz a fim de desenvolver a imaginação no processo criativo. Ele é responsável pelo design de cada coleção, dos motivos de inspiração até a conclusão do processo produtivo, é necessário que coordene e dirija o melhor do próprio time, que é composto de assistente de moda, pesquisador especialista em tecidos, modelista, técnico especialista em design digital. (FAERM, 2010).

Os estilistas de interação ou designers possuem o perfil e as habilidades perceptivas capazes de abstrair as demandas solicitadas por seus clientes, os beneficiários de seu projeto, sempre buscando as inovações e prospectando caminhos através de reflexões intencionais efetuadas no desenvolvimento de novos produtos. O estilista tem possibilidade de interagir através de suportes tecnológicos e objetos orientados: objetos documentais que acompanham a ficha técnica como, por exemplo, amostras de matéria-prima e textura peças piloto, e todos os objetos que são suportes e auxiliam na comunicação do projeto, compondo um cenário criativo para este contexto (NEVES, 2010).

Para Rech (2002, p. 53) “o designer é o profissional responsável em transformar, de maneira consciente e criativa, ideias em forma, através da combinação do trio: tecnologia, materiais, mais o contexto social no sentido de satisfazer o ser humano".

Design pode ser uma atividade de uma equipe com função de desenvolver a inspiração, a percepção do possível e a sua interpretação em termos de produto que possam 
ser produzidos e comercializados, em complemento aos elementos estéticos e funcionais necessários para a concepção de um produto (MENDES, 2010).

$\mathrm{Na}$ criação os estilistas trabalham com os designers de produto a fim de utilizarem o Design com o objetivo de mais eficazmente produzir o produto certo, pelo preço certo, para o mercado certo e na qualidade certa (ARAUJO, 1996).

Segundo Jones (2011 p. 14), um plano de estudo completo para tornar-se um estilista eficiente no desenvolvimento de produto de peças em malharia retilínea abrange:

- Conhecimento da moda contemporânea e do passado;

- Experiência da mídia e da cultura visual;

- Técnicas e métodos de pesquisa;

- Habilidade e desenho de ilustração;

- Conhecimento dos tecidos: tipologia, rendimento, referência de materiais;

- As bases da construção do vestuário de moda: silhueta, proporção, cores e detalhes;

- Princípios básicos do corte de modelos e do caimento ou moulage dos tecidos;

- Costura, construção e tecnologia das bases de modelagem de vestuário;

- Especificações técnicas, colocação das especificações e avaliação de custos;

- Desenvolvimento de uma linha de protótipos para uma pequena coleção de Vestuário;

- Estudo de técnicas de computer-aided design (CAD-CAM);

- Técnicas de apresentação (portfolio) e de comunicação;

- Estúdio independente;

- Trabalhar em Grupo;

- Noções de marketing, branding e economia;

- Questões de éticas e sociais que influenciam a indústria e os consumidores;

- Elaboração de texto, como relações elaboradas em cultura geral;

- Desenvolvimento pessoal e profissional.

O Tecelão começa por entender o funcionamento a máquina retilínea manual para entender como o tecido de malha é produzido, quase tudo que é feito na máquina manual é reproduzido na eletrônica. O processo de desenvolvimento de produto em VMMR para chegar a eficiência, começa por tecer a malha e implica em um conhecimento complexo que vai desde as fibras, fios, passando pela modelagem, até a de programação de máquina

\subsection{Ficha técnica do produto de VMMR}

A ficha técnica é uma ferramenta imprescindível para qualquer processo de desenvolvimento de produto. No caso da malharia retilínea, sua elaboração passa por várias 
etapas. Em primeiro lugar, é necessário observar a necessidade da empresa quanto às muitas possibilidades de escolha de padrões, fios, os recursos criativos e tecnologia do maquinário disponível no decorrer do processo de design do produto.

A ficha técnica do produto é montada por empresas com equipe de desenvolvimento de produto. O estilista concebe o produto, desenha já observando todas as etapas de desenvolvimento de produto. Esta ficha contém todas as informações do processo de modelagem, costura e acabamento do produto; o esboço do estilista com indicações de cores, formas, desenhos, fios, tipo de galga da máquina retilínea, modelagem e outras observações.

O estilista passa a ficha técnica com o desenho e a modelagem para o programador executar o programa com tradução na linguagem da máquina retilínea eletrônica como mostra a figura a seguir:

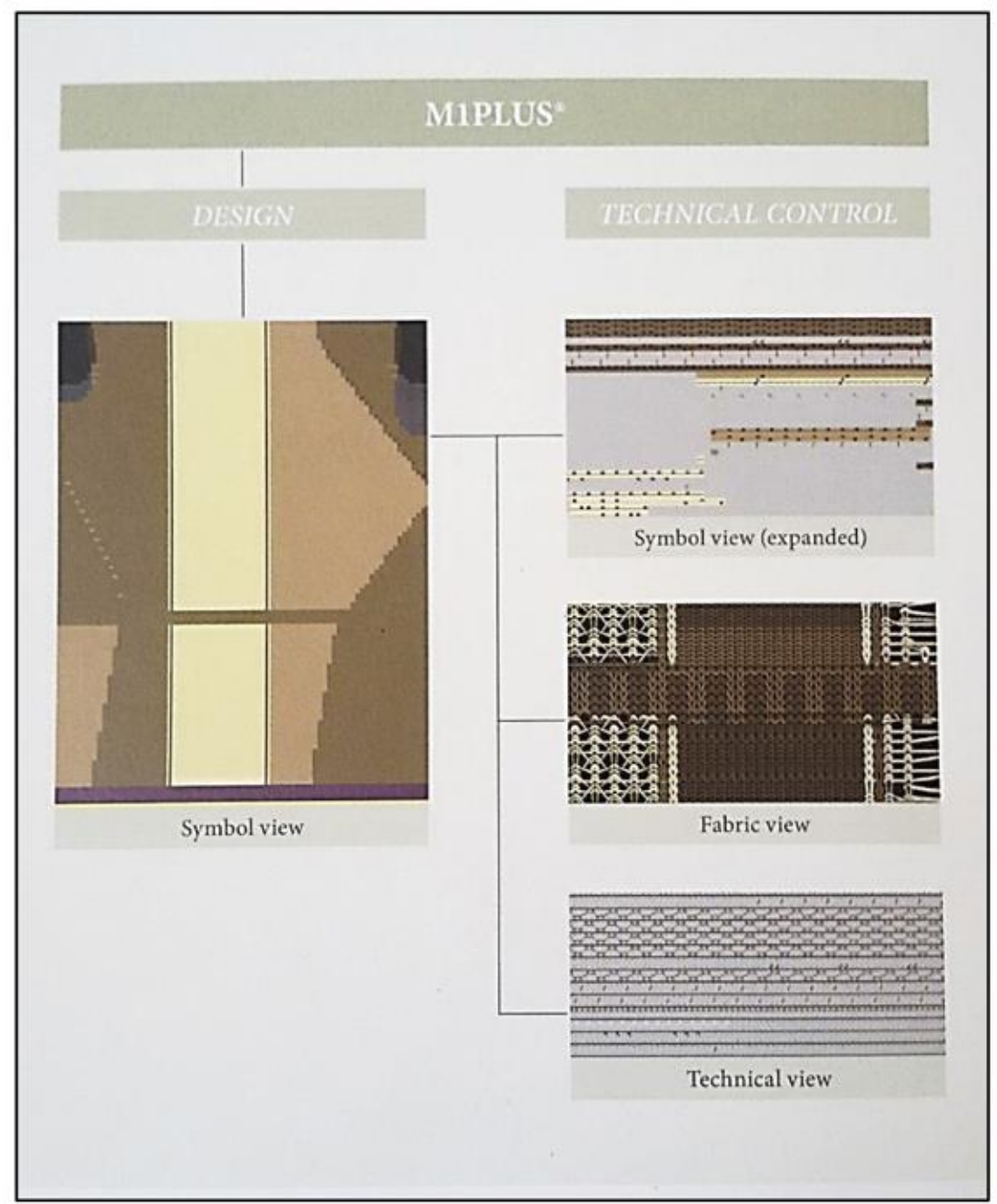

Figura 38 - Painel da máquina eletrônica, tradução simultânea da linguagem técnica para a real. Fonte: STOLL, 2012. 
O programador acompanha este desenvolvimento e acrescenta as informações técnicas de tecimento das amostras da malha onde as informações são mais detalhadas como titulagem do fio, regulagem de pontos, tensão dos fios, tipo de padrão da malha, e muitas outras informações técnicas. Estas informações são modificadas no decorrer do processo de programação do produto e modelagem. Depois de o produto ser aprovado fica sendo a ficha de produção do produto.

Conforme descrito por Mendes (2011, p. 46), as informações básicas que devem ser comunicadas em sequência, como exemplo é:

a) a imagem da criação da peça em croqui;

b) os desenhos das partes da modelagem;

c) a montagem da peça e a sequência de operações;

d) a descrição e as quantidades de cada material utilizado.

Nas figuras a seguir, exemplos de ficha técnica para execução de uma peça piloto no processo de criação de peças de moda em VMMR. Segundo pesquisas de observação, destacamos alguns exemplos de informações detalhadas em fichas técnicas:

- Referência do Produto;

- Croqui - desenho técnico da frente e costa do produto;

- Explicações de detalhes do desenho com pontos e medidas;

- Materiais principais utilizados no produto e quantidades;

- Etapas produtivas, montagem da peça, etapas de corte, costura e acabamento;

- Tempo de produção;

- Especificação de maquinário utilizado;

- Aviamentos utilizados;

- Materiais especiais;

- Composição dos materiais utilizados;

- Situação de desenvolvimento de produto.

Objetivos da Ficha técnica:

- Possibilita a fabricação do produto com instruções bem claras.

- Estabelecer um padrão de qualidade e tamanho para o produto.

- Parâmetros de dados consistentes para cálculo de custo do produto. 
A seguir uma ficha técnica do departamento de estilo elaborada pela empresa de desenvolvimento de produto de VMMR.

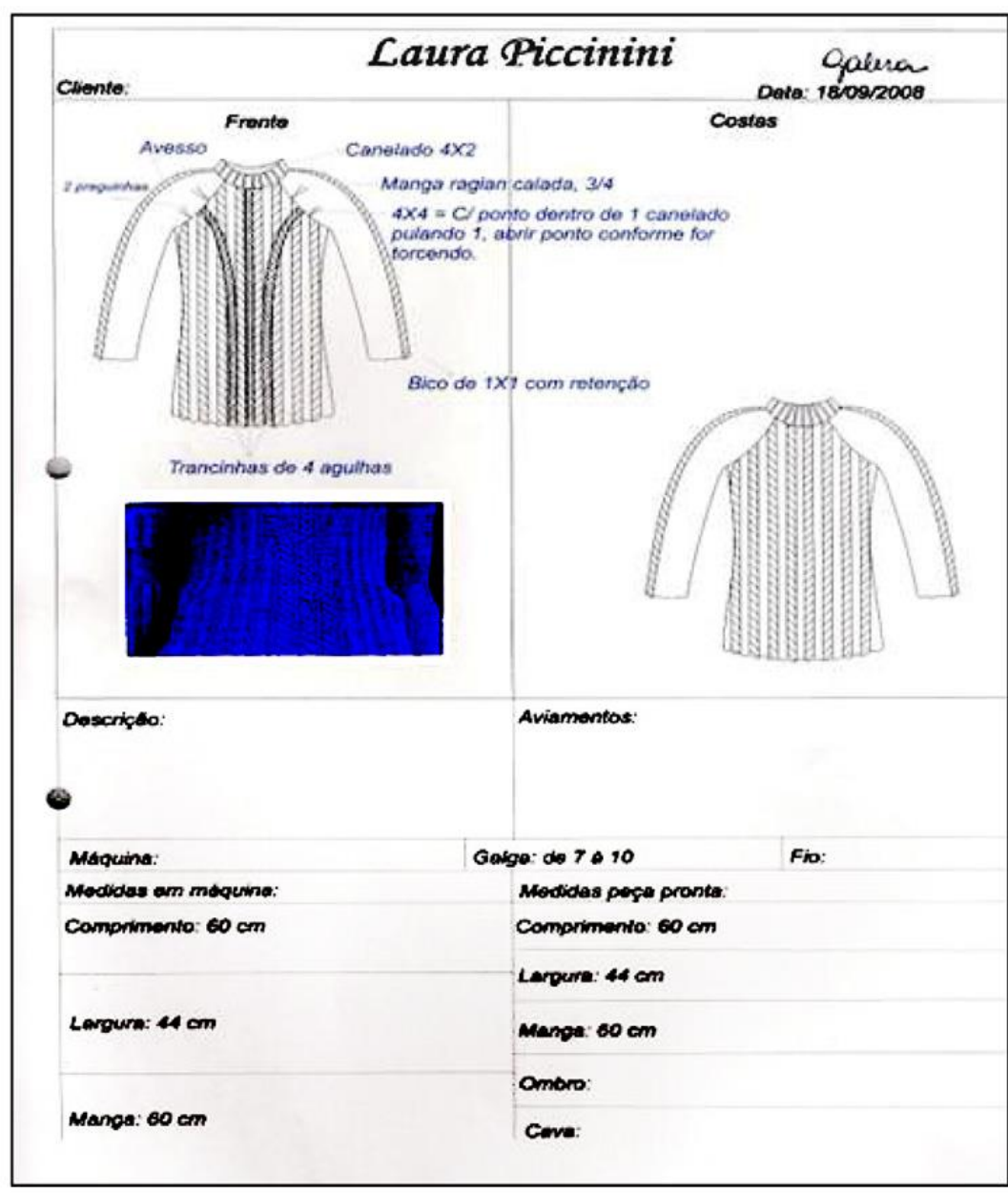

Figura 39 - Ficha técnica simplificada de malharia retilínea de estilo, Monte Sião.

Fonte: Laura Piccinini, 2009.

A ficha é preparada por um programador experiente e contém todas as informações necessárias para executar a programação, como também passar para o tecelão montar a máquina e ajustar os controles para tecer a peça. A seguir a ficha técnica elaborada pelo programador e estilista para desenvolver um produto. 


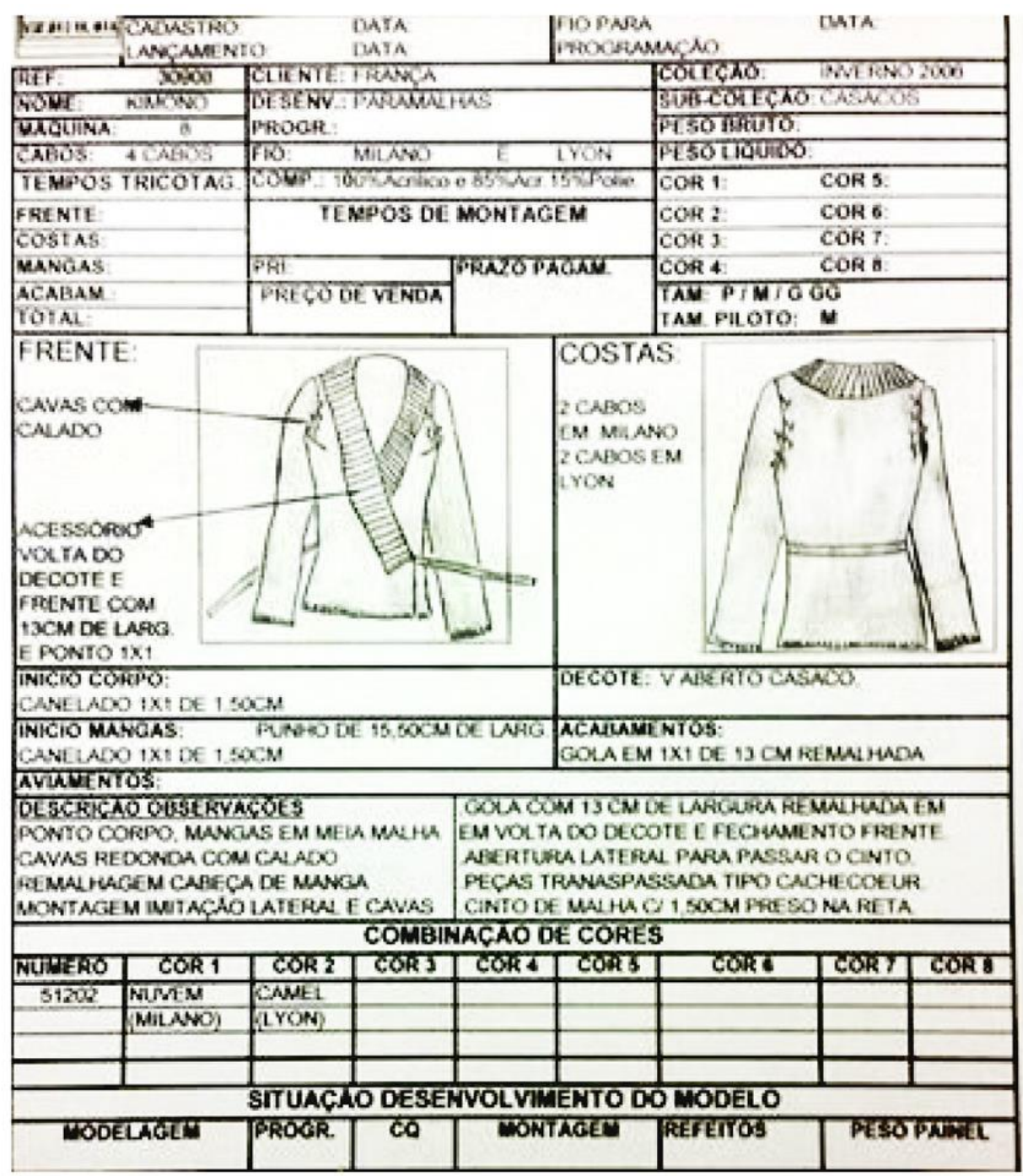

Figura 40 - Ficha técnica por Angela Aronne Marques, estilista, Monte Sião. Fonte: Laura Piccinini, 2008

\subsection{Modelagem no produto de VMMR}

No mercado de vestuário são oferecidos muitos métodos de construção de moldes em modelagem plana ou também denominada 2D. A modelagem plana surgiu com o advento da industrialização no século XVIII. Antes desse período, as modelagens eram feitas diretamente no corpo e modeladas individualmente. A partir do surgimento das fábricas de vestuário foi necessário padronizar medidas e traçar esquemas com tamanhos diferenciados que hoje chamamos de molde. 
Definição de modelagem segundo Mendes (2011, p. 44) "é a operação pela qual o modelista prepara em papel ou em computador o modelo bidimensional que deve ser executado em tecidos, costuras e aviamentos de forma tridimensional”.

A modelagem plana é a base para o corte de todos os produtos de vestuário. Ela serve como matriz para construir no molde de papel ou no computador, as medidas relativas do modelo em partes baseadas no corpo humano. Esse molde, depois de aprovado, vai para o corte do tecido por meio de tesoura ou máquina de corte ou laser.

No caso da malharia retilínea observam-se dois sistemas de corte o manual que é feito em painéis ou tecidos corridos conforme a necessidade ou programados nas máquinas retilíneas eletrônicas. Atualmente a modelagem em máquinas eletrônicas, serve como base na programação do modelo, uma vez programada, as peças saem modeladas da máquina no sistema fully fashioned ou peça pronta.

As medidas que envolvem o molde podem variar de acordo com o público consumidor do vestuário. Entretanto, as fábricas padronizam os moldes dos modelos mais usados, que também são denominados commodities, como camisas, blusas, calças e outros mais, que ficam como a base para construção de outras variações de modelos. Por esse motivo eles são denominados de moldes bases. As empresas normalmente têm os moldes bases dos principais modelos e suas ampliações em outros tamanhos.

Mendes (2011, p. 45) destaca:

“ao receber o croqui do modelo criado, a modelista produz o molde em papel ou sistema computadorizado, a partir da modelagem básica. Seu trabalho deve buscar interpretar da melhor maneira possível as ideias do estilista ao prever as formas a serem obtidas após os cortes e processo de costura para produção em série".

A Modelagem na malharia está ligada à tecnologia da máquina ao ser fabricado o produto. Para o estilista começar a criar modelos, são necessárias noções de tecimento e dos recursos que podem ser feitas as peças em malha retilínea. Normalmente estes conhecimentos são passados nas escolas em máquinas manuais e caseiras. Os princípios de funcionamento e tecimento são os mesmos das máquinas manuais ou as atuais eletrônicas. Para calcular a modelagem é necessário estudar e entender de quantidade de pontos, carreiras, registros e muitas outras coisas.

Para escolher o melhor padrão de tecido para a adequação da modelagem, nas peças de vestuário concebidas pelo estilista são feitos testes de tensão e pontos. O procedimento pode 
ser feito produzindo várias amostras de tensão e pontos, que são medidos com uma forma geométrica padrão, por exemplo, $20 \mathrm{~cm}$ por $20 \mathrm{~cm}$. Escolhido o melhor resultado, anota-se as características. Abaixo um exemplo de cálculo de modelagem de uma blusa, tecimento de uma pequena amostra para contagem de pontos em relação a medida em centímetros.

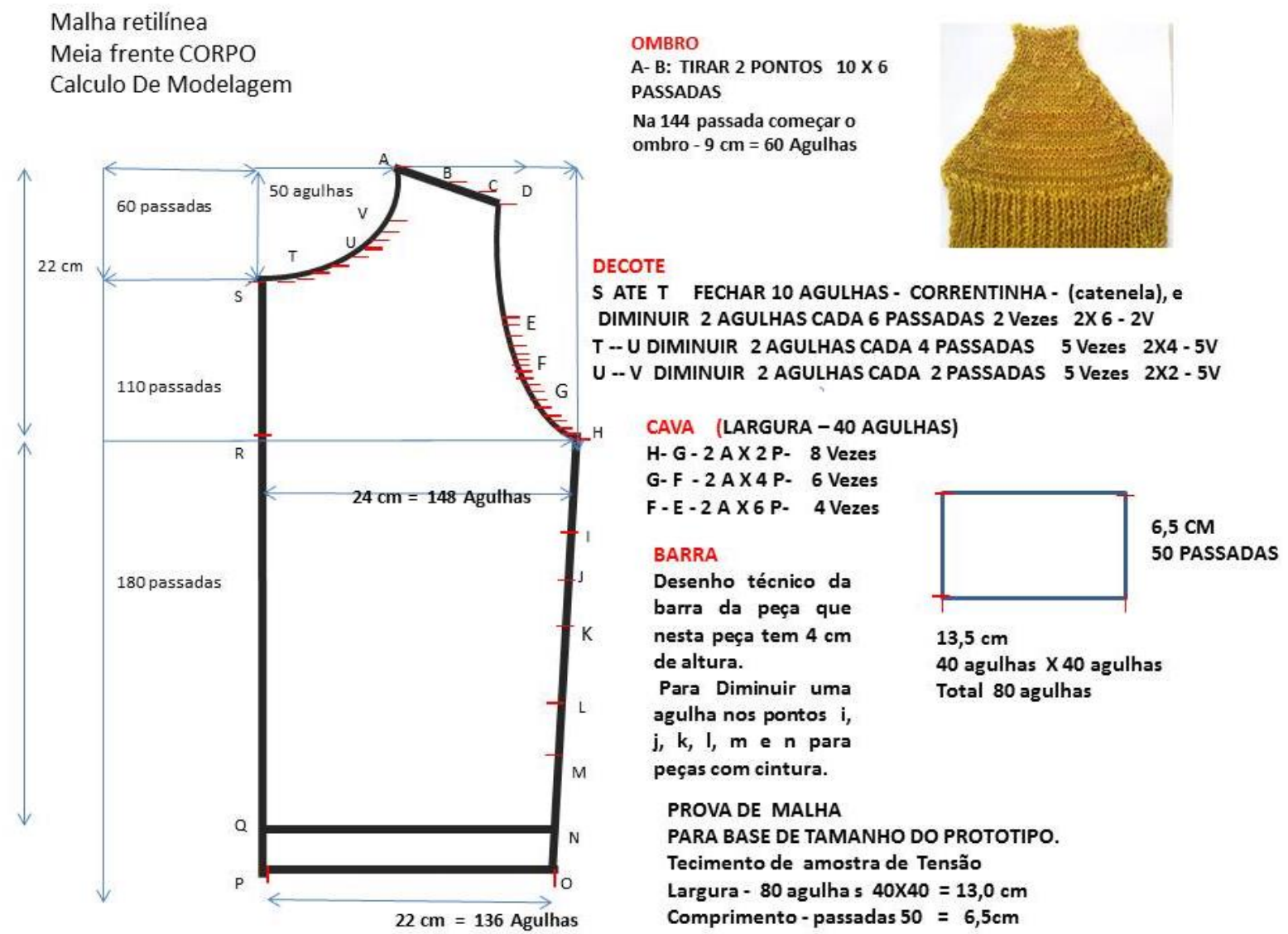

Figura 41 - Cálculo de modelagem, aprendizado inicial em aula de VMMR. Fonte: IUAV, Laura Piccinini.

O modelo final sempre deve ser executado no tecido aprovado e testado no manequim e, ainda, aprovado pelo estilista ou pelo cliente final, isso porque, mesmo que a modificação seja de um simples botão pode por vezes ocorrer erros. Esses erros podem ocorrer por várias razões como: pela mudança do fio que possui diferentes características na composição da matéria-prima; modelagem; acabamentos e muitas outras mais. A modelagem para malharia é diferenciada no desenvolvimento de produto; ela recebe acabamentos como, por exemplo, costuras na remalhadeira nas golas com punhos e galões que mudam totalmente o projeto de produto desejado. A remalhadeira é uma máquina usada na malharia retilínea que costura galões nas extremidades como golas e vivos nas malhas, dando um acabamento perfeito e de qualidade. 
As empresas de malharia retilínea utilizam máquinas diferentes do produto de vestuário de tecido plano e da malharia circular ou plana. No produto de VMMR também são usadas as máquinas básicas como de costura de ponto fixo, overloque de duas agulhas, interloques com três agulhas e galoneiras. Porém, na construção da peça de malha ainda é necessário as mesas especiais de passadoria, fechadeiras, remalhadeiras, e galoneiras especiais de máquina retilínea.

A tendência dos últimos anos trouxe uma novidade de acabar e costurar as malhas retilíneas no mesmo sistema da malha plana ou circular. Isso aconteceu com a moda de tecer tecidos cada vez mais finos para o verão, como também para facilitar o processo de confecção do produto.

Grave (2004, p. 54) observa "Reavaliando a moda e o trabalho de modelagem, podemos falar que a moda veste e se desenvolve pela interatividade das fibras e tecidos, enquanto a modelagem trabalha a leitura do "design", referindo-se a cobertura do corpo." A moda deve conceder qualidades de conforto no vestir e satisfazer as vontades estéticas e sociais do indivíduo. A modelagem adequada ao conceito da criação do artista, se obtém com um estudo dos materiais escolhidos e a sua adequação às técnicas de modelagem disponíveis.

Os tecidos planos e os de malha surgiram praticamente na mesma época; porém, os tecidos planos sempre dominaram o mercado do vestuário. Nas últimas décadas, a malha vem ganhando seu espaço pelo fato de dar mais liberdade de movimento ao corpo. As modelagens em malha têm características diferentes da plana pela sua elasticidade, textura e peso. A construção e criação do protótipo de vestuário em malharia são feito em modelagem tridimensional.

Segundo ensina Kathia Castilho,

\footnotetext{
"Em sua construção de forma métrica, o tecido oscila em diferentes tipos de trama e já possui uma característica tridimensional e qualidades que lhe são intrínsecas, como por exemplo, o volume e a textura. A textura é aprendida em menor medida pela visão e necessita do tato para realizar o reconhecimento sensível" (1998, p. 106).
}

Esta experiência material na malharia retilínea torna-se rica pela plasticidade da malha. A malha tem características que deformam o produto de acordo com variáveis como peso, elasticidade, gramatura e deformação. Estas características físicas podem ser importantes dependendo do corte do produto para favorecer o estilo e o conforto que o estilista quer imprimir na peça final. 
No desenvolvimento da modelagem podem-se usar modelagens que ampliem as possibilidades de uso desse produto como costuras, por exemplo, de franzidos, drapeados, babados, e muitas outras possibilidades. A modelagem deve respeitar as medidas do corpo para um perfeito caimento deste produto de malha a fim de deixar este corpo livre para execução de movimentos.

A modelagem e seus acabamentos são os fatores que agregam qualidade e consequentemente valor ao produto de Malharia Retilínea. Por isso, para estudá-los será necessário integrar conhecimentos de diversas áreas, tais como, áreas de design, desenvolvimento de produto e programação da máquina, modelagem, tecelagem, acabamentos, materiais e fibras e métodos de criatividade. As informações no projeto têxtil tem uma linguagem complexa, devido ser uma área multidisciplinar, o que torna a comunicação mais difícil de nivelar seu conhecimento. O mercado esta exigente, é necessário ter uma estratégia de investir em muitos pontos para desenvolver um produto com qualidade em todos os níveis de sua produção e criação como flexibilidade; inovação e criatividade e redução de custos (RECH, 2006).

A criação de modelagem de produtos diferenciados do VMMR é normalmente feita sobre o manequim de moulage e depois passada para a modelagem plana. O moulage sendo uma técnica de modelagem tridimensional com prática escultórica, indicada principalmente no ato de criar e interpretar uma ideia do designer ou estilista.

O Modelista é um profissional próximo do criador, compete a ele a técnica de manipulação do tecido sobre o manequim. Esta técnica também usada para a alta costura deriva do estudo dos volumes em três dimensões. O modelista apoia o tecido diretamente sobre o manequim, servindo-se de alfinetes e com a técnica de drappegio ou também chamada moulage vai marcando os pontos com alfinetes e marcando os detalhes principais da peça de vestuário, até visualizar o resultado adequado a ideia do criador ou estilista. Aprovado o modelo, a modelista passa o modelo para o papel a fim de planificar a peça e preparar a primeira tela de um tecido que será cortada e costurada para visualizar a primeira prova do modelo (FRISA, 2014, p 407, tradução nossa).

A modelagem plana é usada para criação de produtos de vestuário na indústria, mantendo uma base de medidas padrão da empresa, confeccionam-se moldes padrão dos principais produtos e modificando os detalhes e estilos para atender as tendências das mudanças de estação e criações dos estilistas. Segundo Grave, (2004, p.12), “A modelagem 
com fundamento multidisciplinar deve disponibilizar a "máquina humana", dentro do seu princípio maior, pensamento e sentimento, ação e motricidade, tornando o vestuário interativo, respondendo ao interior e ao exterior do indivíduo".

Há fatores que diferenciam a modelagem da malha retilínea da modelagem no tecido. Muitas vezes na malharia, é necessário modificar o molde padrão pelas especificidades da malha como, por exemplo, a elasticidade.

Segundo Sissons, (2010, p. 114)

\begin{abstract}
"o manequim tem um papel importante no processo de modelagem da forma. Bases de modelagem, padronagens e peças de malha podem ser conferidas e ajustadas. As bases também podem ser moldadas direto no manequim, sem o uso de moldes de papel, parte de um resultado visual mais rápido; esse é um método de corte de moldes normalmente preferido pelos iniciantes. No entanto, os melhores resultados são conseguidos por meio de combinação de moldes planos com a moulage no manequim, e é importante conhecer ambos".
\end{abstract}

A Moulage integra conhecimentos interdisciplinares do design de moda assim como as habilidades específicas do estilista, como visão espacial e tátil. Essa segunda pele ou veste modela o corpo e oferece mais recursos para o fim de ser usado como adorno, proteção, comunicação prática e estética. O ensino da Moulage é importante porque prepara o aluno a compreender a dinâmica da modelagem plana, os ajustes necessários para executar uma boa modelagem, o busto se projeta para frente provocando sobras de tecido que se transformam em penses, o pescoço e cavas determinam contornos para passagem da cabeça e dos membros, e o tecido tende a esticar mais nos lugares onde é cortado e enviesado. A moulage ainda serve como técnica para complementar a modelagem plana em possíveis retificações e correções.

A Moulage veio através dos tempos como uma técnica empírica para construção de roupas e no fim do século XIX, com a industrialização, começou a formar os primeiros alfaiates, e consequentemente a padronização dos modelos e moldes para a indústria. No mundo da moda ainda é valorizado peças únicas e o aspecto do feito a mão. No inicio do século XX, Madame Violet e Madame Grass tornou a técnica conhecida, favorecendo a inovação da moda na época. Esta técnica é mais livre e permite ao estilista e o modelista interagir e criar formas diferenciadas. Na moda mais sofisticada ou alta moda essa técnica é a base da criação, pois o tecido é esculpido no corpo do cliente, com suas medidas individuais resultando em um molde único. Neste caso, pode-se dizer que o modelo transcende o valor de 
consumo e passa a ser visto muitas vezes como uma obra de arte, visto que sua execução fica por conta de artesãos.

O manequim é um suporte que tem um formato com medidas próximas ao biotipo mediano feminino, masculino ou infantil, dependendo da necessidade do cliente. O molde é extraído diretamente do corpo do manequim de moulage dando uma maior precisão e qualidade na roupa. Assim, como uma técnica escultora, modela o tecido no corpo possibilitando enxergar os detalhes de costura, caimento do tecido, conforto, anatomia, adequação do modelo ao usuário, ampliando a criatividade e sensibilidade do estilista e modelistas. No produto de VMMR, muitas vezes o tecelão produz um tecido de malha quadrado no tamanho do molde e entrega para o estilista fazer o teste junto ao modelista. $\mathrm{O}$ modelista trabalha o tecido de malha, por meio da técnica de moulage, para viabilizar a ideia do estilista.

Segundo Faerm:

“Alguns estilistas tem por hábito visualizar as formas finais dos Modelos antes de desenhar sua peça piloto. Nessa exercitação, eles aprendem as alternativas da fluidez entre os elementos bidimensionais e tridimensionais do design. Esta experimentação de modelar os tecidos no manequim ajuda a antecipar o resultado final da ideia." (2010, p.110).

Muitos tecidos de malha são produzidos com fios que possuem elastano. A fiação mistura a fibra principal com 2 a $6 \%$ de filamento de elastano para dar uma maior elasticidade ao tecido Grave descreve o fio de elastano:

"Por apresentar fibra de borracha, sua função é aderir ao corpo. A homogeneidade da massa em relação ao volume corporal não permite que deslize. Modela-se ao corpo aderindo a ele. Os atributos tecnológicos formam os tecidos e influem na aparência, no desempenho, na segurança e no conforto" (2004, p.46).

Esta elasticidade contribui para a estabilidade do tecido e ao mesmo tempo concede um caimento e qualidade melhorada ao vestuário de malha. A qualidade do vestuário está ligada principalmente à composição dos fios e sua tecnologia. Na malharia é mais aconselhável fazer o molde inteiro da peça, uma vez que os modelos podem sair deformados no meio molde, devido ao peso e elasticidade do tecido de malha.

As bases do corpo usadas para malha são diferentes daqueles utilizados para materiais de tecido plano, elas não têm penses, são um pouco mais justas e, devido a natureza do tecido elástico, não tem margem de costura incluída. Cada designer ou empresa vai usar bases que sejam adaptadas 
para servirem em seu estilo particular de malhas. Os moldes são testados, em primeiro lugar com tecidos de toile de Jérsei, para conferir as linhas de design. Os ajustes do projeto são feitos em toile de Jérsei, nos manequins de prova, para depois serem transferidos para a malha final e transformados em molde para tecer. Amostras de malha e testes parciais podem ser feitos para testar a elasticidade da malha em relação ao toile de Jérsei (SISSONS, 2010, p. 115).

Cada tipo de peça de roupa exige uma base específica. Por exemplo, a base básica do corpo sem penses e a base sem folgas, ambas com mais folga do que a base do corpo ajustado, é mais adequada para casacos ou jaquetas mais folgados (SISSONS, 2010).

Segundo Jeanine Pierson, (2011), em São Paulo uma das mestras em moulage no Brasil, entende que, nas peças com maior dificuldade, é aconselhável começar pelas costas para dar estrutura na modelagem, facilitando a execução do modelo. Depois de muitas experimentações e trabalhos, quando a modelista se torna profissional nesse tipo de modelagem, ela pode se permitir a mesclar as duas técnicas, as bases da modelagem plana com a moulage.. A seguir o manequim de prova de modelagem em moulage com um tecido de meia malha para iniciar as experimentações em modelagem.

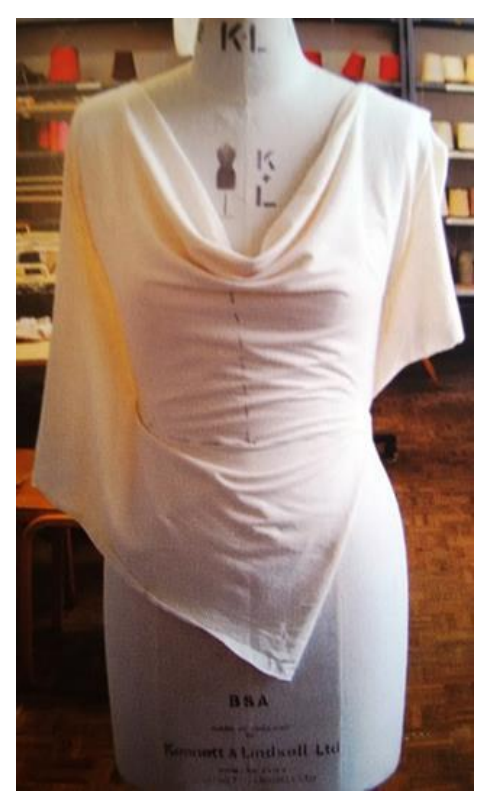

Figura 42 - Manequim de Moulage, prova de Modelagem em tecido de malha. Fonte: Laura Piccinini.

Na malharia retilínea, esta modelagem padronizada também é utilizada, porém, ela tem muitas variações de medidas para atender tanto ao material elástico e com diversos pesos, como também a infinidade de possibilidades modal do tecido. As etapas resumidas para execução da modelagem, utilizando a técnica de moulage, são as seguintes: 
- Preparo do manequim - o manequim deve estar marcado com os pontos principais e fitilhados com as principais medidas de largura e altura do corpo. O centro do corpo também deve ser marcado do pescoço, entre bustos, cintura e quadril. Ainda é preciso marcar a linha do ombro nas costas e a cava.

- Cortar o tecido no fio da malha - que é a parte em que as beiradas do tecido que ficam de pé verticalmente, uma quantidade suficiente para trabalhar o modelo. Normalmente usamos um tecido de malha mais simples para fazer o teste. Marca-se o fio com um esquadro e uma linha vertical e uma horizontal para ter o tecido bem enquadrado. No caso da figura a seguir, foi feito um teste com malha com elastano cortada no viés para fazer um modelo drapeado.

- Coloca-se o tecido a partir do meio para as laterais, prendendo o centro à lateral no ponto mais largo do busto. Com as mãos, devagar, ir levando o tecido nas laterais e verificar as sobras, e colocar as penses de acordo com o modelo pensado; repetir nas costas, prender com alfinetes e marcar os pontos. Depois, colocar a gola e as mangas e repetir as marcações. Usar uma caneta hidrográfica de ponta fina, para demarcar toda a volta dos recortes da peça, pense e recortes.

- Retirar as partes do manequim com todos os alfinetes e marcações possíveis para passar para o papel pardo e planifica a moulage. Depois de passar todos os riscos com as penses, pregas, decote, comprimento franzidos, colocar a costura que varia de 0,5 $\mathrm{cm}$ para peças infantis até $2,0 \mathrm{~cm}$ para peças de alta costura. $\mathrm{Na}$ figura a seguir, observa-se um modelo em malharia retilínea desenvolvido na técnica de moulage na Universidade de Caxias do Sul. Nesse modelo foram utilizados diversos tipos de tecidos de malha, com trabalhos diferentes, muitos recortes, colocados sobre o manequim. Depois da aprovação deste modelo pelo estilista, o modelista passa a peça costurada para o programador de máquina retilínea. 


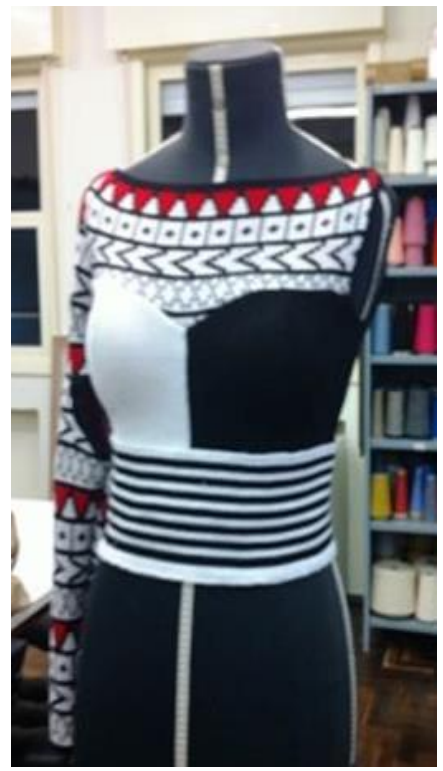

Figura 43 - Sala de modelagem em moulage da Universidade de Caxias do Sul, 2013.

A moulage, como ferramenta de criação, pede que se deixe uma boa folga de costura para eventuais acertos de modelagem e medidas, seguindo assim para a prova de corpo e retificações na modelagem plana. Quando as partes são franzidas, penses e pregas, é necessário marcar as duas extremidades e as medidas finais das duas partes. Depois da peça aprovada estas costuras são eliminadas, pois as malhas de malharia retilínea não precisam ter folga para costura. As malhas de qualidade são costuradas com máquinas que não deixam bordas. A seguir modelos desenvolvidos em moulage com elementos tridimensionais apresentados na feira Pitti Fillati de 2011.

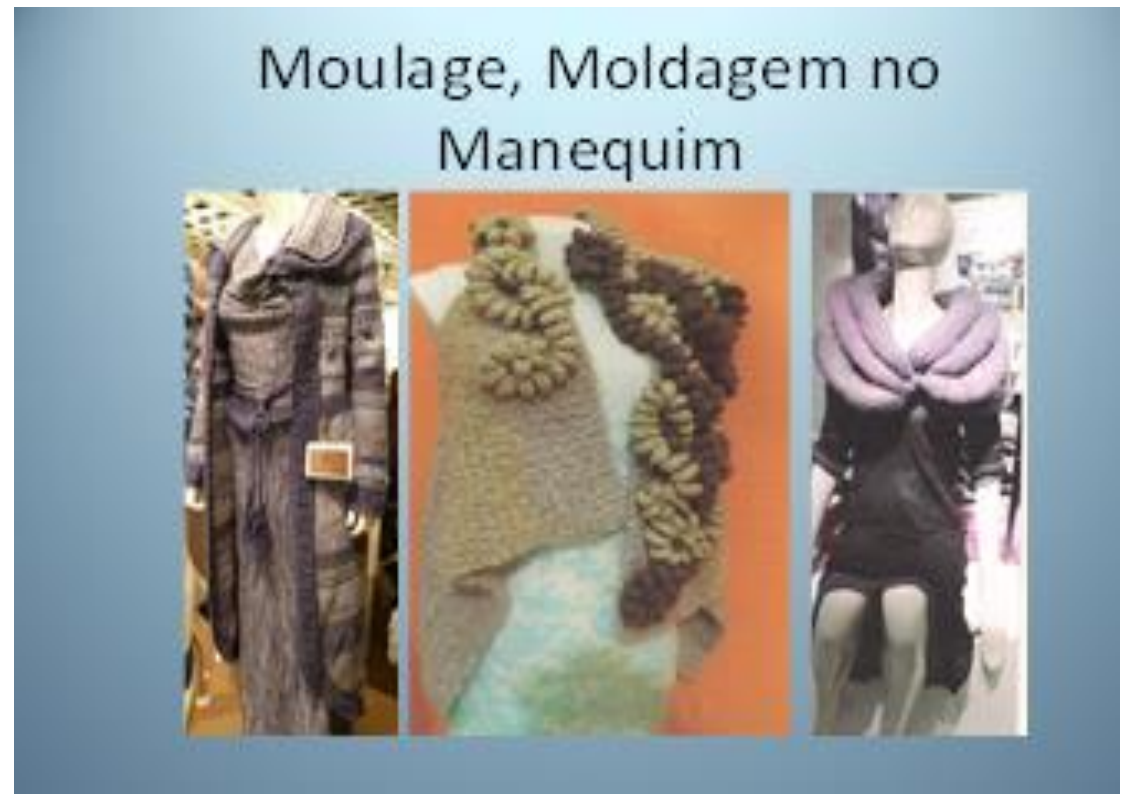

Figura 44 - Criatividade em modelagens com técnica de moulage em MR, Pitti Filati, Itália, 2011. 
Após a base ter se transformado em um molde desenvolvido, o molde de malha pode ser calculado. O molde contém o número de pontos e carreiras em cada seção, calculados tomando-se todas as medidas horizontais e verticais do molde e usando-se a amostra de tensão da amostra de malha. . Nas máquinas eletrônicas de peça pronta, as malhas não têm costuras. Os modelos aprovados passam para a pilotagem final com aprovação dos moldes e descrição na ficha técnica de todo o processo de produção e etapas a serem executadas.

\subsection{Costura e acabamento no VMMR}

A maioria dos produtos de vestuário na malharia retilínea é utilizada na parte superior do corpo, como blusas, casacos, etc. Esses artigos de VMMR são constituídos de três partes principais separadas (frente, costa e mangas), as quais são costuradas entre si, resultando uma peça de malha pronta para vestir. Nas peças mais elaboradas, as peças podem ter muito mais partes, dependo da ideia do estilista.

Para essa operação de juntar as partes da peça, são necessárias máquinas de costura e acabamentos adequados à produção de malharia retilínea. As máquinas que trabalham com malharia devem ser reguladas de acordo com as especificidades de cada tecido de malha. Observa-se que quanto menos costuras tem uma malha, mais qualidade ela apresenta. Isso se deve ao fato que as partes da peça podem sair prontas da máquina, na técnica Wholergarment, e ser costurada com as bordas já definidas. Este processo não passa pelo corte, não sendo necessário usar o acabamento de costura, assim a malha sai muito mais bem acabada, limpa, em menos tempo e sem descartes de fios e tecidos.

As máquinas mais utilizadas para junção das partes cortadas ou moldadas por calado de um tecido de malha retilínea é a máquina de costura reta e a remalhadeira. As máquinas de costura da malharia retilínea são adaptadas com agulhas e equipamentos específicos de acordo com as espessuras dos pontos e suas elasticidades e peso. A malha tem características muito diferentes dos tecidos planos. A costura em malha deve ter regulagem com pontos mais largos e usados com linhas de costura especiais.

Muitas empresas no Brasil, que produzem malhas com custos mais baixos, usam processos com corte das partes e costuram utilizando várias máquinas como: costura ponto fixo, overloque, interloque, fechadeira, remalhadeira e ponto invisível. 
As terminações dos tecidos de malharia retilínea, como bordas e barras, devem ser muito bem acabadas porque nos tecidos de trama tem laçada que facilmente se desmancham nas suas terminações. As terminações das partes como punhos e barras, são acabadas pela máquina, passando uma carreira de fio remalhando à última carreira.

O produto de malha tem muitas possibilidades de acabamento e, quando se trata de moda, ele pode determinar caminhos complexos, de acordo com o material e a ideia a desenvolver. Por exemplo, no caso de tecidos de malha muito espessos - que são desenvolvidas em máquinas finura três com uma aparência artesanal - a costura deve ser bem cuidada para se obter um caimento solto e natural. A aparência mais elaborada vai depender da habilidade da operadora de máquina de costura e sua equipe, e assim para dar mais valor ao produto. Os acabamentos de uma peça como gola, bolsos, punhos e adereços podem sair prontos da máquina, segundo o tipo de tecnologias empregado. Estes complementos podem ser colocados depois, por meio de uma máquina especial de costura denominada remalhadeira. A seguir a figura com a colocação de uma gola em uma remalhadeira.

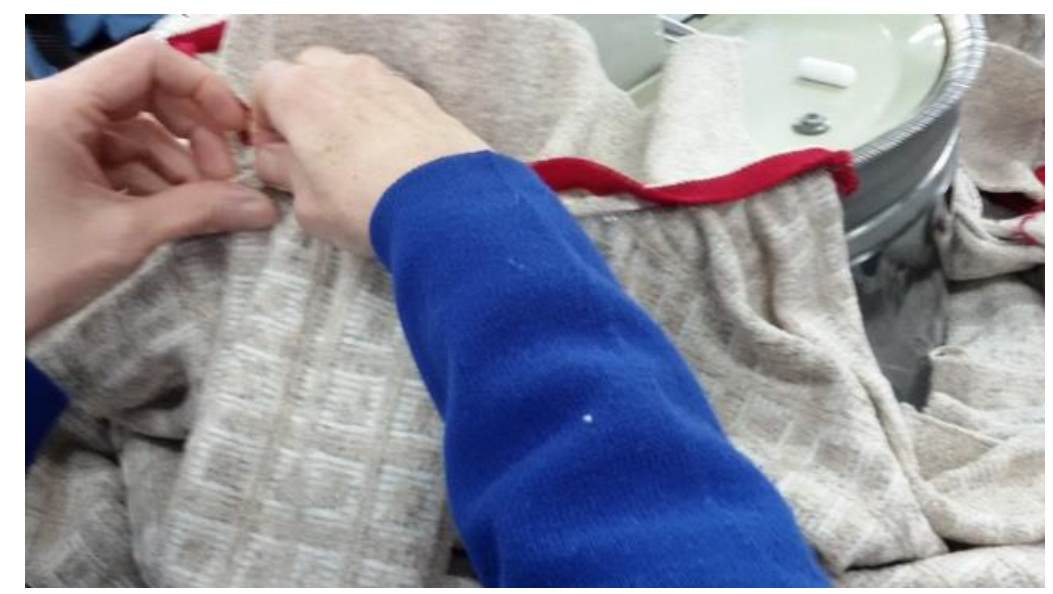

Figura 45 - Remalhadeira, Malharia. Fonte: Laura Piccinini, 2014.

A remalhadeira é um tipo de máquina que costura partes da peça de malha sem deixar emendas aparentes na peça. Ela costura com um processo de arremate passando o fio entre os pontos dos dois tecidos por meio de entrelaçamento de duas agulhas em uma placa como um pente circular. Esse tipo de costura com aspecto mais uniforme oferece muitas possibilidades de criar novas formas. A remalhadeira é muito útil para costurar galões de vivos em golas e terminações das malhas e detalhes decorativos nas peças. $\mathrm{O}$ trabalho de remalhar é manual e artesanal, usado principalmente nas indústrias de artigos elaborados. A maioria das empresas com alta produção não usam remalhadeiras, pois o tempo despendido reduza a produção. 


\section{Moda no produto de Vestuário de Malharia Retilínea}

O conceito de moda nasceu no final da Idade Média, século XIV, quando os burgueses que enriqueciam, começavam a imitar as roupas dos nobres da corte europeia. O que fazia com que os nobres, por sua vez, criassem novas peças, com a ideia de se diferenciarem da classe rica emergente. Além do princípio de diferenciar as classes sociais e sexo, a moda buscava a individualidade que, com o nascimento do sistema capitalista, acabou por profissionalizar o conceito de moda (PALOMINO, 2002).

Foram publicados muitos livros ao longo da história sobre o tricô, a partir de uma variedade de perspectivas, cada um oferecendo uma visão sobre técnicas, estilos, padrões e histórias anteriormente não registradas, cada um oferecendo novas perspectivas sobre a disciplina, celebrando o tricô como uma atividade que tem sua própria história, motivos e próprio público e aumentando o potencial de tricô como um meio interdisciplinar. Fazer tricô não é apenas sobre a prática comum, interna, mas pode se enquadrar em um meio de fazer arte, artesanato, design, cinema, performance e moda, bem como a busca de lazer. (TURNEI, 2009, p. 2).

Segundo Godart (2010, p. 29)

"Moda", do latim, Modus, designa a maneira de fazer, compartilhando nesse caso o sentido
do termo inglês fashion, que deriva do Francês façon (feitio). "A moda é, portanto, a maneira
de fazer alguma coisa, em particular de vestir-se, comer, falar, etc".

Para Godart (2010, p. 10) “a moda pode ser definida como um tipo de mudança social específica. Essa mudança é regular porque produz a intervalos constantes e quase sempre curtos, duas vezes por ano no caso da moda relativa ao vestuário e de suas coleções primavera/verão e outono/inverno". O que para algumas pessoas a moda é atividade de sobrevivência social, política e financeira, para outras passa despercebida ou utilizada como proteção e conforto do corpo.

No começo do século XX, a moda, acompanhando o desenvolvimento da indústria, teve uma grande revolução com o lançamento de roupas mais práticas que se adaptaram aos novos tempos. Na era da industrialização o prêt-à-porter foi a denominação de uma tendência de moda que democratizou a moda. Segundo Lipovestsky (1989, p. 75), “A partir dos anos 1920, com a simplificação do vestuário feminino de que Chanel é de alguma maneira o símbolo, a moda se torna, com efeito, menos inacessível porque mais facilmente imitável" e o autor continua “As mulheres usarão, doravante, vestidos justos, curtos e simples, chapéus em 
forma de sino, calças e malhas de lã, Chanel poderá vestir mulheres de alta sociedade com Tailleur de Jérsei, com pulôver cinza, preto ou bege". Madame Chanel marcou o inicio do prêt-à-porter. Roupa para serem usadas durante todo o tempo, com suas saias justas, casaquinhos muito elegantes adornados com botões dourados e colar de pérolas.

Nos anos 40 e 50 do século passado chegaram as garotas sweater, inventadas pela máquina de Glamour de Hollywood. Suas roupas exploravam as propriedades da elasticidade do tecido tricotado por completo, possuindo a qualidade de revelar o corpo ou abrigá-lo ao mesmo tempo. As fibras novas e mais flexíveis, foram misturadas à lã, para criar uma gama mais ampla de desenhos, cores, texturas e possibilidades de uso. Na década de 1960, o tricô estabeleceu-se fortemente no mundo da moda (BLACK, 2002).

No início da era industrial as roupas foram simplificadas a um vestir mais prático. Nesta evolução de formas ela se democratizou, porém, ainda percebem-se as diferenças e preferências pessoais. A moda tende a diferenciar o indivíduo na sociedade, inserir o indivíduo em um grupo que transmita sua personalidade.

Lipovetsky (1989, p. 33) acrescenta "a novidade tornou-se fonte de valor mundano, marca de excelência social; é preciso seguir "o que se faz" de novo e adotar as últimas mudanças do momento: o presente se impôs como o eixo temporal que rege uma face superficial, mas prestigiosa da vida das elites".

Godart (2010, p. 34)

"a moda, interagindo com numerosos outros campos culturais proporciona aos indivíduos e aos grupos os sinais para que eles construam sua identidade, que, então, não é mais unicamente estatutária, mas também "estilística", não é mais somente vertical, hierárquica, mas também "horizontal", ou seja, não hierárquica".

A moda esta associada ao fator tempo, e se manifesta em ondas que são cíclicas, se sobrepondo em diferentes espaços. Segundo Castilho (1990, p. 8),

\footnotetext{
"a ação de decorar, ornamentar, vestir e revestir o corpo por intermédio de trajes ou adornos, que se articulam com o corpo humano, ou ainda a conjunção de tais elementos decorativos sobre a superfície natural do próprio corpo, a pele, é um exercício constante de percepção em relação ao universo cultural, no qual esse encontra-se inserido".
}

Para Avelar (2009, p. 173), "a moda oscila entre consumo e arte. Ela tem que passar pela experimentação de formas, de materiais, de referências e cores, num processo de estudo que sustente e viabilize a criação". 
A difusão da Moda é muito particular porque, por um lado, ela é organizada pela indústria no seu conjunto e porque, por outro, não existe moda "melhor" em absoluto. Nisso os desfiles de moda diferenciam-se dos salões profissionais de outras indústrias, como a indústria automobilística ou aeronáutica, nas quais a ideia de progresso tecnológico é central. Enquanto a maior parte das atividades artísticas e científicas está fundamentada na ideia de que existem obras ou teorias intrínsecas e absolutamente melhores que outras, a moda vai ao encontro do contextual e efêmero (GODART, 2010, p. 70).

Para Avelar (2009, p. 93) "a moda parece antecipar a individualização coletiva, graças à sua rapidez de renovação e a sua capacidade de detectar grupos. Pesquisas cada vez mais especializadas focalizam indicadores de novos estilos de vida. Aliados à difusão das informações por aparatos digitais, levam a ideia de tendência não só a se difundir instantaneamente, como também a diversificar".

Os métodos de produção da alta costura evoluíram muito pouco desde os primeiros dias da moda: eles permanecem essencialmente manuais e requerem uma grande especialização técnica, o que explica o preço final das roupas. Karl Lagerfeld e sua equipe desenham os croquis e escolhem os tecidos, as "primeiras do ateliê ou primeira oficina: pequenas mãos de pessoas experientes (que ganharam experiência em costura e são responsáveis pelos seus workshops) revelam-se indispensáveis para concretizar as "visões" dos criadores. A alta costura se mantém, portanto, como uma atividade essencialmente artesanal e artística" (GODART, 2010, p. 45).

A novidade tornou-se fonte de valor, posição social, ambição, fantasia, imaginação, riqueza de conteúdo, inovação, provocação, fortes significados, arte. No progresso continuado no design é preciso seguir "o que se faz" de novo e adotar as últimas mudanças do momento: o presente se impôs como o eixo temporal que rege uma face superficial, mas prestigiosa da vida das elites. (LIPOVETSKY, 1989).

Treptow (2007, p. 26), conclui o conceito de moda;

"Na era do consumo em massa, podemos concluir que moda é, os valores materiais nos bens de consumo massificados, em que, à medida que vão sendo consumidos, pautam as relações entre pessoas a partir das aparências e de um ciclo de obsolescência programada que privilegia aquilo que é novo”. 
Treptow salienta que (2007, p. 26), “a moda é um fenômeno social de caráter temporário que descreve a aceitação a disseminação de um padrão ou estilo, pelo mercado consumidor, até a sua massificação e consequente obsolescência como diferenciador social”.

O início do século XXI, marca a existência de um número limitado de capitais da moda: Nova York, Paris, Londres e Milão. Godart descreve (2010, p. 57): “A dinâmica das capitais da moda permite então abordar a questão da globalização de diferentes pontos de vista, associando o global e o local”. O autor ainda cita que também são importantes as cidades de Copenhague, Estocolmo ou Berlim com influência estilística por intermédio de outras artes, o cinema, a música, por exemplo. Finalmente, algumas cidades ocupam lugar importante na moda mas, de um ponto de vista econômico; é o caso de Barcelona, Madri, Moscou, Bombaim, Hong Kong ou Xangai (Godart, 2010, p. 59).

Como resultado da revolução do consumo, depois da Segunda Guerra Mundial a sociedade manchada pela pobreza, o produto de VMMR, também denominado tricô, não apenas caiu em desuso, mas tornou-se firmemente estabelecido como um signo distanciado do sistema de moda e foi destinado a ser uma escolha de commodity. O tricô feito à mão que antes da guerra era motivo de encontro das mulheres e um meio social muito utilizado para o lazer, depois da guerra com a necessidade de agasalho, caiu como um artigo comum e até depreciado, pois muitas malhas eram feitas de outras peças desmanchadas e com reaproveitamento dos fios. Recentemente, o tricô feito artesanalmente é apresentado como uma atividade de luxo, exclusivo e caro, o que também pode ser um meio de afastar a dependência de produtos fabricados em massa.

Neste sentido, a malharia retilínea pela sua plasticidade destaca-se no design, pois pode construir um apelo sensual na sua aderência, transparência e caimento que realçam o corpo.

Para Castilho (1998, p. 25)

"a criatividade humana em realizar e concretizar exemplos neste sentido é infindável,
tanto quanto os recursos utilizáveis. Se, num primeiro momento, a decoração corpórea
valia-se de procedimentos efetuados diretamente sobre a própria pele, ou seja, o
tecido, enquanto segunda pele que reveste e recobre esta primeira, propiciará outras
tantas possibilidades".

A criação de modelos no VMMR é mais complexo no seu processo de desenvolvimento e produção. $\mathrm{O}$ ciclo produtivo começa pela escolha do fio, depois vem o tecimento da malha e finaliza com o acabamento. Esse longo processo de escolhas acaba 
sendo mais um fator de diferenciação de estilo. Os atuais sistemas de criação são desenvolvidos no setor de design de moda com uma equipe multidisciplinar envolvendo principalmente, os programadores, estilistas e modelistas de máquinas retilíneas.

\subsection{Estudos em Moda e estilistas relevantes no processo de criação de VMMR}

O fascínio da malharia reside na possibilidade de criar do nada a trama e a forma; dela deriva uma inacreditável variedade de efeitos e modelos, válidos para todos os gostos e todas as categorias de design. Das peças piloto de fios de cashmere muito leves que são vistos sempre nos desfiles de Jill Sander às óperas esculturais de Giles Deacon e Alexander Mcqueen, hábitos de noite de fios de Jérsei opaco de Madame Grès - frequentemente citado nos desfiles de moda dos modernos estilistas - o vestuário esportivo a clássica t-shirt, a malharia se adapta a uma ampla gama de segmentos de mercado, preços de venda, idade e estilos de vida (FAERM, 2010, p. 64).

O fenômeno de "aposta no futuro" encontra-se de maneira impressionante na moda, na qual os ciclos de produção iniciam-se muito cedo, com uma antecedência, em certos casos, de até dezoito meses, Segundo GODART (2010, p. 41): “A centralização da moda é assegurada pelas casas de moda, que criam os estilos e designs que são vistos nos desfiles das principais cidades do mundo".

A moda inspira-se muito regularmente em outras artes, por exemplo, quando o costureiro Yves Saint Laurent (1936-2008) cria vários vestidos inspirados em pinturas de Mondrian (GODART, 2010).

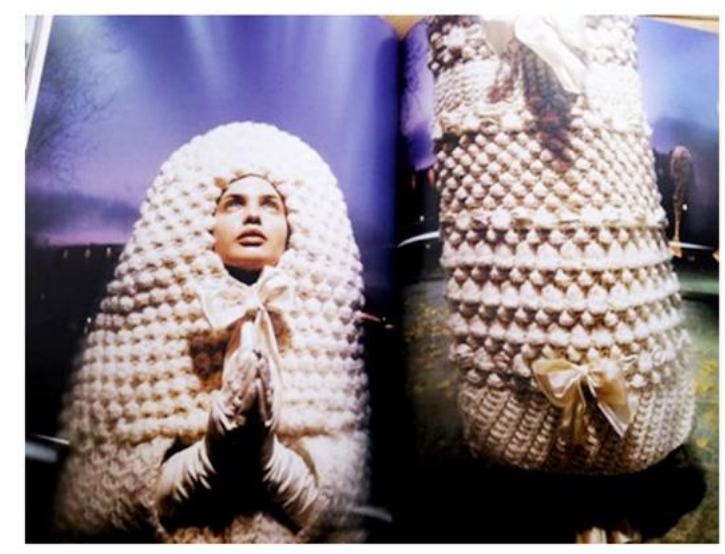

Figura 46 - Yves Saint Laurent, 1968. 
O objetivo do estilista de moda é, portanto, o de recriar por meio dos aspectos formais nas roupas, as qualidades picturais, o conjunto de traços que caracterizam a vestimenta como um objeto estético. Assim, percebe-se que o trabalho criativo da moda propõe a articulação de dois eixos, isto é, o eixo paradigmático (da escolha), qualidade do tecido, cores, formas, etc. e o eixo sintagmático (da combinação) em que trabalhará as possibilidades combinatórias entre a cor, o tecido, etc. (Castilho, 1998, p. 96 e p. 97).

A moda em vestuário tem sua expressão máxima na alta costura e segundo Frisa (FRISA, 2014, p. 401, tradução nossa).

"O trabalho disciplinado, meticuloso e precioso da alta moda - expressão de uma pesquisa no estilo e na construção do vestuário - é o reconhecimento de um ato criativo. A alta moda italiana, depois da Segunda Guerra Mundial, trabalha sabiamente, e não sem conflitos, a pesquisa de uma própria identidade criativa que a emancipa da "haute couture" parisiense, com visão, operacionalidade e inspiração, passando a ter um reconhecimento mundial. A peça piloto ou a peça única de alta costura é produzida com cortes e costuras e procedimentos de aperfeiçoamentos manuais e artesanais para definir o desenho. No primeiro lugar de hierarquia da criação, o criador, se dirige o interno ateliê como um diretor de uma orchestra e seu primeiro gesto é elaborar o modelo com um desenho de esboço ou também drapeando diretamente o tecido sobre um manequim ou uma modelo (moulage). Segue uma verificação do desenho e seus detalhes com a ajuda da gerente de produto ou da modelista. Geralmente, o gerente de produto ou "Premier", no caso de alta costura, que tradicionalmente é a pessoa mais próxima ao criador, ao qual vem confiado o delicado trabalho de interpretação inicial do esboço. Neste momento, entra em cena a figura da modelista que tem o trabalho de reportar o modelo para o papel de modelagem, e seguir o trabalho de experimentação em provas em tecido de tela de morim em algodão. Seguem as provas e eventuais modificações antes de passar a fase de corte e costura. O gerente escolhe as costureiras mais adequadas e especializadas ao tipo de trabalho pedido na peça, enquanto as assistentes distribuem os trabalhos de acabamento às costureiras mais experientes. As peças vão para a aprovação final e seguem as próximas fases de produção e comercialização dependendo do direcionamento do consumidor da marca".

Apesar de a tecnologia ser uma parceira do design no VMMR, destaca-se ainda o poder do trabalho artesanal na diferenciação de produto. Segundo a conceituação tradicional, a diferença entre design e artesanato reside no fato de que o designer projeta o objeto para ser 
fabricado por outras mãos ou, de preferência, por meios mecânicos. O artesão concebe e executa (MENDES, 2010).

Neste sentido, o tricô ainda usa do recurso do artesanato e da customização em alguns casos para chegar a resultados únicos e inusitados.

Um exemplo muito utilizado no VMMR é a customização. Os estilistas buscam o diferencial na customização, definido como prática que consiste em alterar peças compradas, aplicando furos, rasgos, rabiscos, usa de alfinetes e outros materiais. As empresas de malharia utilizam esses recursos no processo de concepção de produto. Considerada como um protesto contra a ditadura da moda, a customização favoreceu a individualidade inventiva. (MENDES, 2010).

No VMMR esta técnica de customização evoluiu e apareceu como tendência nas últimas coleções. No processo de moda os estilistas estão cada vez mais usando este recurso para aplicar detalhes sobre malhas que são denominadas "comerciais" ou commodities. Estes detalhes são escolhidos conforme as informações antecipadas de tendências lançadas pelos comitês internacionais. As últimas coleções de malhas retilíneas estão customizadas com muito brilho, rendas e paetê. A seguir, apresento alguns estilistas importantes, como exemplo de processo criativo no desenvolvimento de produto de VMMR.

No desenvolvimento de uma coleção de moda em vestuário de Malharia Retilinea pode ser valorizado por suas características de extrema criatividade e caimento no corpo. Marcas de VMMR, como Misson e Issey Miyake, utilizam os recursos das inovações tecnológicas das máquinas eletrônicas de malharia retilínea para se diferenciar no mercado. Somente um estudo profundo das técnicas disponibilizadas pelas tecnologias dos maquinários permite criar, desenhar e executar padrões diferenciados nesse segmento de vestuário.

No ano de 1916, Chanel descobre as possibilidades do tricô confeccionado industrialmente e inclui o tecido de Jérsei novo e flexível com caída perfeita para seus vestidos tubos aderentes e casaquinhos com saia ou calças que se tornam sinônimo de seu nome. 


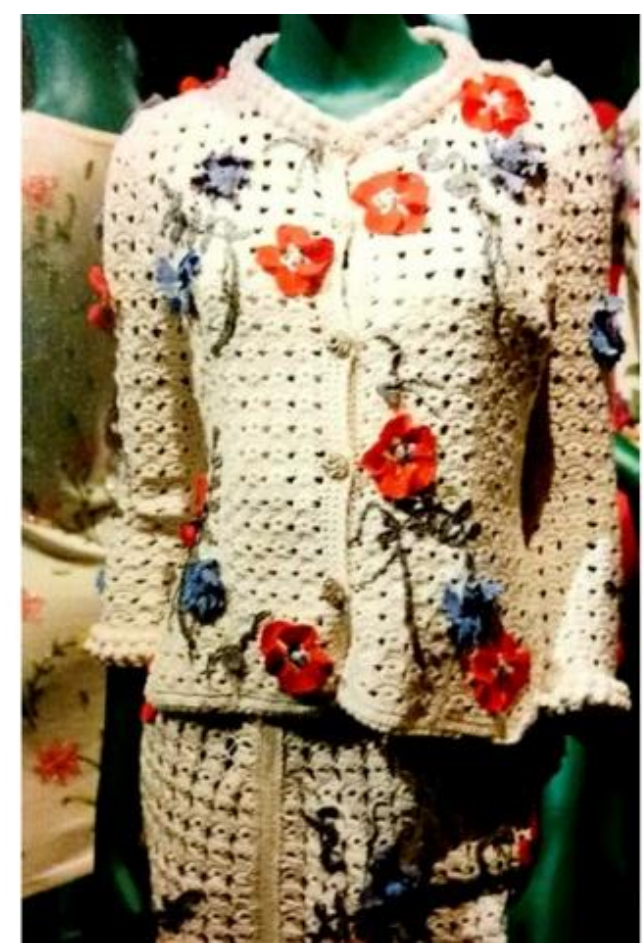

Figura 47 - Chanel

A qualidade das criações da estilista Schiaparelli, contemporânea de Chanel, é devida ao aspecto sólido e indeformável de um tecido de origem armênia. Esse tecido introduz uma técnica de malha de ponto Jérsei com aspecto de tweed, passando um fio de lã de outra cor que vem preso cada quatro pontos, a fim de estabilizar a superfície. Ela tem um enorme sucesso com seu estilo inspirado no movimento modernista, decorações geométricas e motivos africanos em malhas grossas feitas a mão (MISSONI, 2006, p. 176, tradução nossa).

Com a Guerra Mundial, o vestuário de malha é caracterizado por um estilo simples, sem ornamentos. As revistas de moda, empobrecidas pela crise econômica, fornecem modelos essenciais, sumariamente explicados e ilustrados. São exemplos de malhas feitas a mão como instrumento precioso a serviço das mulheres para tecer malhas à comunidade carente de roupas de lã para proteção ao frio. Entre as duas guerras mundiais, a primeira coleção de malha foi de Jean Patou, composta por peças esportivas e costumes de banho com malha de Jérsei, cujo repertório figurativo era composto por decorações artísticas de vanguarda em listras e zig zag (MISSONI, 2006, p. 175, tradução nossa).

Depois da Segunda Guerra Mundial, o processamento mecânico de tecer malhas tornou-se generalizado na Itália. Surgiram muitas marcas especializadas em produtos de alta qualidade, baseados na criatividade e qualitativas pesquisas no foco do circuito da moda. Os 
distritos mais importantes onde se concentraram as indústrias foram Carpi, Modena e região da Romana (FRISA, 2011, p. 51).

Em 1956 Luísa Spagnoli mostrou uma nova dimensão de malharia com uma coleção de extraordinários tecidos de Jérsei em delicado e encantador fio de lã, sugerindo um tom especial de uma elegância focada em impressionantes pesquisas na informalidade.

A partir dos anos 1950, a marquesa Olga de Gresy desenvolve malhas de luxo para exportação com a marca Mirsa. A sua empresa comercializa produtos de malha para lojas de departamento em Los Angeles e São Francisco e vestem muitas atrizes americanas.

A ascensão da malharia Italiana se deve a muitos fatores econômicos e técnicos: os dotes de criatividade e tradições culturais das malharias italianas, maior disponibilidade de matéria prima, estrutura produtiva do tipo artesanal desordenada, mas flexível, que há dezenas de anos foi se especializando em meias e roupa íntima, entre outros motivos.

Um salto de qualidade da malharia italiana vem do fato de que em 1951, quando Giovani Battisti Giorgini, com boa intuição e criatividade, convidou os compradores norte americanos para assistirem a um desfile em Firenze. Ele apresentou roupas para boutique criada por estilistas emergentes, e foi um sucesso inesperado.

O papel dos jornalistas nos anos quarenta e cinquenta foi fundamental não só para desenvolver a imagem da moda italiana, mas acima de tudo para desencadear um processo de autoconhecimento através da comparação com o resto do mundo, e especialmente com Paris. Os costureiros franceses eram extremamente organizados e, sobretudo se valendo do seu prestígio e se apropriando das autorias italianas. O esforço italiano não é de renunciar a cópia, mas construir um sistema de design, produção e trabalho de comunicação em conjunto para creditar o papel da Itália no panorama internacional (MONTI, 2014, p. 37, tradução nossa).

Estes modelos não tinham a concorrência de Paris, pois eram roupas mais informais para todas as horas. As sucessivas edições nas prestigiosas salas do palácio Pitti, em Florença, ficaram como ponto de referência da Moda Italiana para a clientela estrangeira, como expressão de uma Itália moderna, eficiente e criativa. Os compradores reconhecem na proposta Fiorentina a boa qualidade com preços interessantes para responder a exigência das mulheres americanas que trabalham fora e querem se vestir com classe e sem ostentação (MISSONI, 2006, p. 179, tradução nossa).

Vaccari (2014, p. 50, tradução nossa) explica: 


\begin{abstract}
"Da segunda metade dos anos sessenta as coleções de alta moda pronta são fincados nas novas linhas com conteúdos criativos e realizados em um diverso contexto industrial. E agora que a direção da Câmera nacional da moda elabora a definição de "prêt-à-porter de alta moda" para terem casas de alta moda pronta que produzem confecção e indústrias que produzem coleções originais, ou derivadas das criações de alta moda. A múltipla identidade da alta moda italiana fala em alta moda clássica, como também de alta moda boutique e alta moda pronta".
\end{abstract}

Neste contexto histórico da moda nasceu o vestuário de moda industrializado em boutiques multimarcas com peças de qualidade chamadas de "prêt-à-porter", que até hoje estão nos melhores centros comerciais.

Outra pioneira da alta moda pronta made in Italy é Mariuccia Mandelli, conhecida como Krizia, além de ser estilista de alfaiataria nutre uma paixão pela malharia. Em 1967, lança industrialmente a marca Kriziamaglia, lança a moda das grandes malhas com inspirações animais que se deixa para trás o pequeno e tradicional Twin-set (duas peças de malha composta, de blusa e casaquinho com tecido de malha fino acompanhando a silhueta do corpo). Na mesma década, os irmãos Benetton fundam um simples laboratório especializado em malharia com preços acessíveis e com bom conteúdo de moda. Benetton se distingue pela capacidade de seguir as mudanças da moda e os pedidos do consumidor reprogramando produção e distribuição nas próprias redes de lija em tempos muito breves (Missione, p.182, 2006).

Em 1970, em paralelo com o grande desenvolvimento da moda italiana o com conceito de made in Italy, foram apoiadas pela parceria estabelecida entre as empresas na indústria e designers de "up-and-coming". Dentro de tal cenário uma nova rede de relacionamentos foi implementada com informações e iniciativas, ativada em parte pelo reconhecimento do valor significativo de malhas na moda italiana. Foi realizada a primeira edição da Pitti Immagine Filati, uma feira dedicada à introdução de inovações no setor, data de 1977 em Florença. Um fluxo contínuo de novas malhas e processos continuaram a fornecer novas ferramentas para projetos de malhas; texturas que permitiram variar com infinidades de efeitos de superfícies, estruturas de fios diferenciados e pontos de renda, processos de acabamento criativos e numerosas formas de aplicações, como bordados, peles e pedrarias (FRISA; DANESE, 2011, p. 52).

A partir dos anos 1970, nasce o fenômeno do estilismo e marcas como Missoni, Biagiotti, Krizia, Albertina, Avagolf, Benetton colocam seus produtos-marcas-imagem em mercados internacionais, e Milão se tornou a capital da moda em Malharia Retilínea. Com as criações de 
vestidos, longos cardigans, blusas colantes cm Laura Biagiotti e Krizia. No segmento de consumo temos Benetton, pioneira em sweters básicos, multicoloridos dos anos 1960.

Nesta época, em 1968, houve uma valorização do tricô artesanal, aquele feito à mão, em grande parte devido à disponibilidade de fios diferenciados, padrões atualizados e moda étnica vigente no momento. As novas tecnologias impulsionaram designer a criar em VMMR, com misturas de técnicas artesanais com os estilistas ingleses como Suzan Duck, Sasha Kagan.

Kenzo nos anos de 1970 misturou a sua herança japonesa com as influências globais e resultou em tecidos em jacquard multicoloridos com partes geométricas e florais. Na figura a seguir, uma veste com silhueta desestruturada mostrando a evolução do seu estilo em 1988 em jacquard monocromático, são trabalhados com diferentes espessuras de fios que resultam em jogos de relevos e transparências na superfície do tecido.

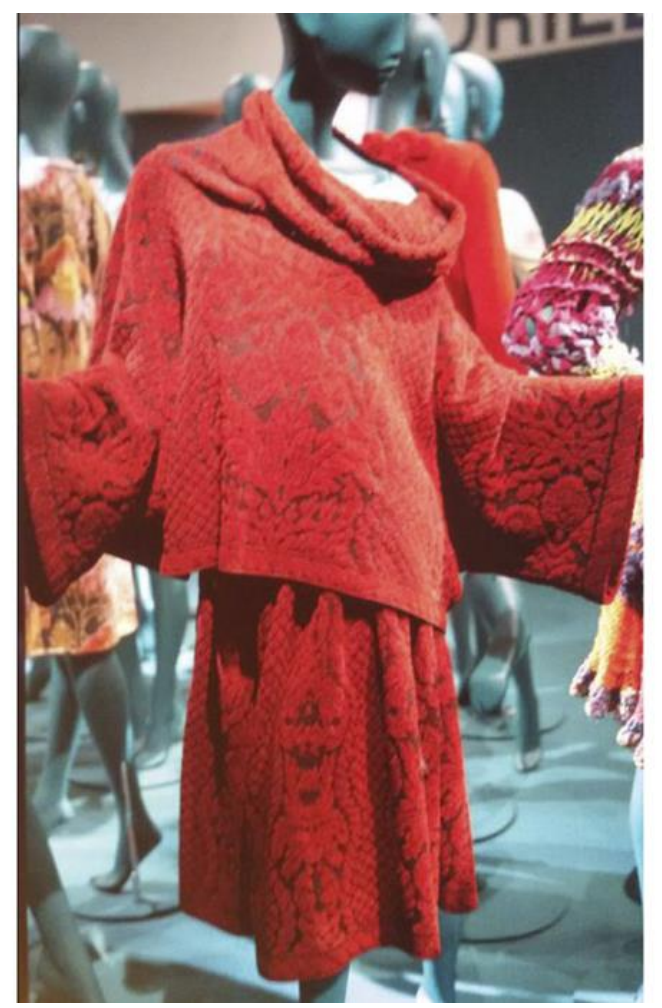

Figura 48 - Kenzo,1987-1988, p.186. Fonte: Maglifico.

Durante os anos 1980 a volta do minimalismo Vivienne Westwood, fez uso de fibras de luxo como cashmere, com profusão de jacquard e intarcias. Os vestidos também tiveram importância na VMMR, devido ao trabalho dos designers como Givenchy, Julien Macdonald, Lagerfeld e Chanel, criando silhuetas sexy, com texturas com revelação corporal e fantasia, glamoroso. 
São muitos estilistas que trabalharam com malharia retilínea. A seguir apresento três estilistas importantes como exemplo de processo criativo em VMMR.

\subsubsection{Emilio Pucci}

O Marquês Emilio Pucci nasceu em 1914 em Nápoles. O seu primeiro prêmio em moda foi o Neiman Marcus Fashion Awards graças a suas peças simples, coloridas e cômodas, adaptadas ao estilo de vida americano dinâmico e esportivo (FRISA, 2014, p. 421, tradução nossa).

A fórmula desta coleção de 1954 foi usar um fio de seda fino e leve com trabalho em ponto Jérsei e criou leves desenhos decorativos coloridos com jogos de estampas regulares em vários formatos geométricos. Pucci mostrou a malha com a elegância da alfaiataria, na expressão do comportamento e estilo de vida ligado ao conforto térmico, abriu caminho para material flexível, adequado para comportamentos e estilos mais informais (FRISA, DANESE, 1985, p. 151). Na figura a seguir, um vestido com estampa que caracteriza a marca, com motivos geométricos multicoloridos.

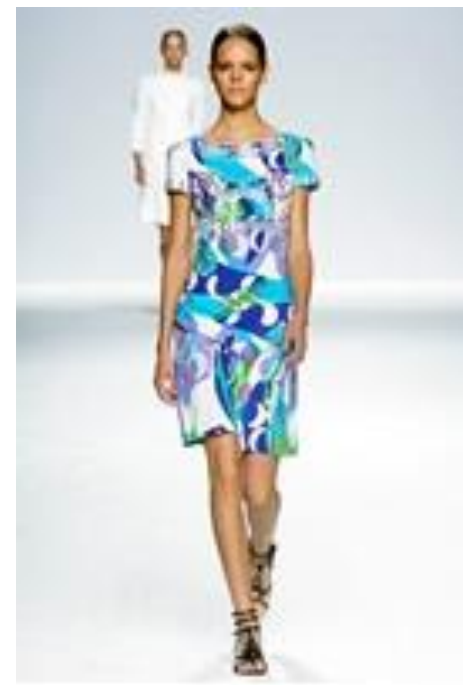

Figura 49 - Modelo da marca Emilio Pucci. Fonte: Pucci, 2010.

Na década de 1960, a seda, o algodão macio e o ponto Jérsei tornaram-se um componente crítico da boutique de moda italiana: além de Emilio Pucci, muitos outros designers e etiqueta, como Ken Scott, Fedeli, Avon Celli e Ritz, criaram roupas em Tricô.

Pucci famoso pela sua qualidade e reconhecível pela exclusividade de seus padrões, no ano de 1960 a sua coleção usando um material sintético fino, feito de seda e helanca, cuja 
aplicação mais importante tinha sido uma cápsula pós-ski explicar. “Capsule 'e não' terno 'uma vez que após 1957, ano do lançamento da primeira cápsula Sputnik, a era espacial havia se tornado o caminho do futuro". Ele apresentou corpos delgados e tonificados, contribuindo para uma exibição da modernidade decorrente da qualidade artificial de cores e materiais semelhantes de uma película de filme perfeitamente esticadas.

Acentuada pela suavidade de seda ou de fios sintéticos, a ausência de material de relevo leva o a malha de Jérsei a uma direção oposta a das malhas e mais próxima aos tecidos planos. Para esse efeito, o processo utilizado para a fabricação destas peças de vestuário é quase igual ao utilizado para outros materiais: as várias partes que compõem a peça de vestuário são cortadas de novo a partir da superfície contínua e subsequentemente costuradas (FRISA, DANESE, 2011, p. 48).

Depois da sua morte, em 1992, a sua filha Laudomia assumiu a direção da marca. A partir de 2000 a marca é controlada pelo grupo LVMH (Louis Vuitton Möet Hennessy) e a direção artística feita por Perter Dundas.

\subsubsection{Família Missoni}

Ottavio Missoni ama contar que, o fato de ter se tornado famoso pelas listras, é fruto de uma pura casualidade, somente porque as primeiras máquinas tinham este padrão de construção de malhas. Este padrão evoluiu com as máquinas e as listras transformadas em Zig zag, motivos geométricos esfumaçados com cores cromáticas dos mais acesos aos mais delicados, com fantasias invernais ou primaveris, através de incessantes experimentações de acordo com as cores e formas que lembram a vanguarda do século XIX. Entre os estilistas italianos, Missoni, são assinalados por uma marca inovativa no vestuário, seja pela forma, ou pela peculiaridade do meio utilizado, a malha, extraordinariamente adaptada a envolver o corpo. Neste propósito, pode-se recordar que Ottavio, antes de ser estilista, junto com Rosina, foi um atleta de valor. Foi detentor do titulo italiano dos "400 obstáculos", finalista da Olimpíada de Londres em 1948, sabia como ninguém projetar malhas que não dificultassem os movimentos do corpo.

As Criações de Missoni são resultados de uma dupla pesquisa, que é sobre técnica dos fios e suas várias possibilidades de entrelaçamento, como também sobre a combinação cuidadosa das cores na perspectiva de uma produção serial. Trata-se de uma liberdade das 
fórmulas de vestimentas, os criadores trabalham sem vínculos, com a mente aberta as inovações, sem ligações com técnicas preestabelecidas. Nasceram de Ottavio e Rosina, esta filosofia que foi convivente dos filhos Vittorio, Luca e Angela, uma família de criativa que tem poucos exemplos iguais no mundo da moda e design.

As criações da família Missoni sempre souberam usar as técnicas produtivas mais novas, capazes de criar grafismos insólitos que envolvem os corpos femininos com arabescos coloridos, desenhos com inspirações da arte e folclore percorrendo alegres tramas nos casacos, saias, túnicas e malhas e com muitos acessórios combinados. São jogos de cores e desenhos cromáticos, sobreposições de padrões, misturas de fios e pontos que resultam em uma vestimenta informal e alegre de roupas coordenadas ao mesmo tempo descoordenadas (Sgubin, R, in MISSONI, 2006, p.12, tradução nossa). A seguir, experimentações de motivos coloridos, como exemplo de processo criativo.

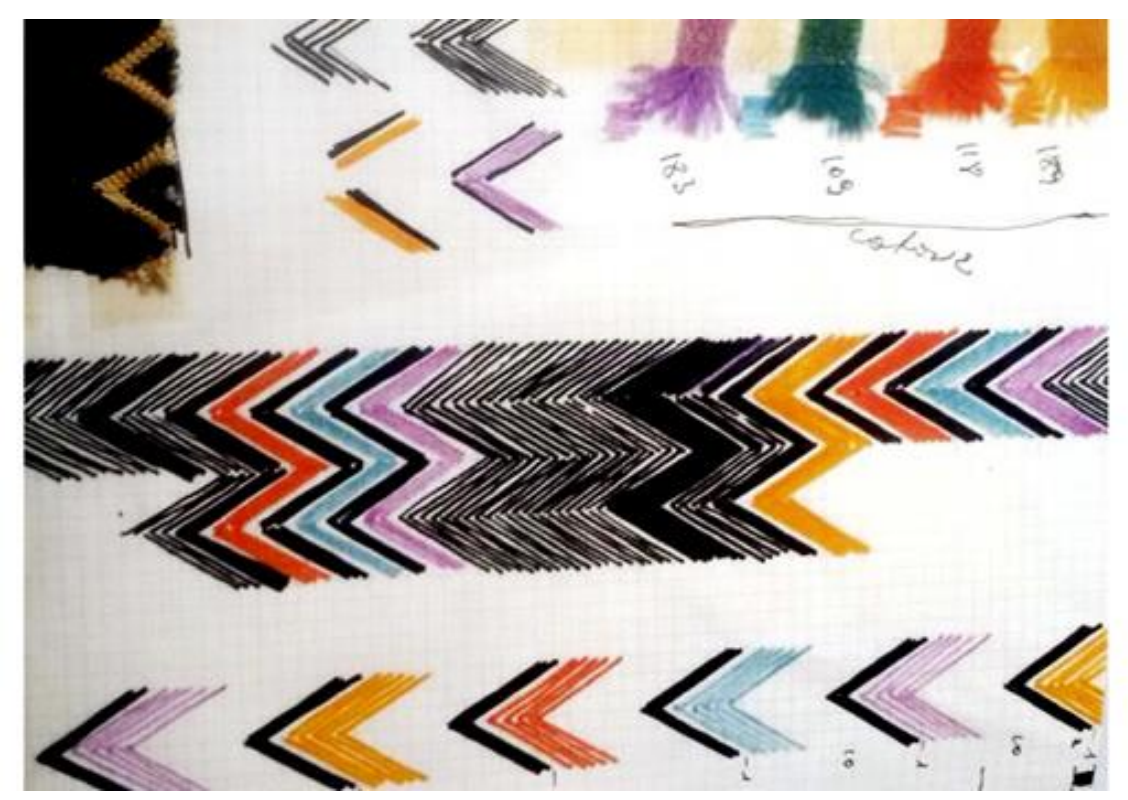

Figura 50 - Estudo de formas, cores e fios, Ottavio Missoni. Fonte: Missoni, 2006.

Missoni foi um exemplo de trabalho sistemático em processo criativo de VMMR que aliou a arte com a tecnologia em toda sua trajetória profissional como observamos nas duas figuras a seguir. 


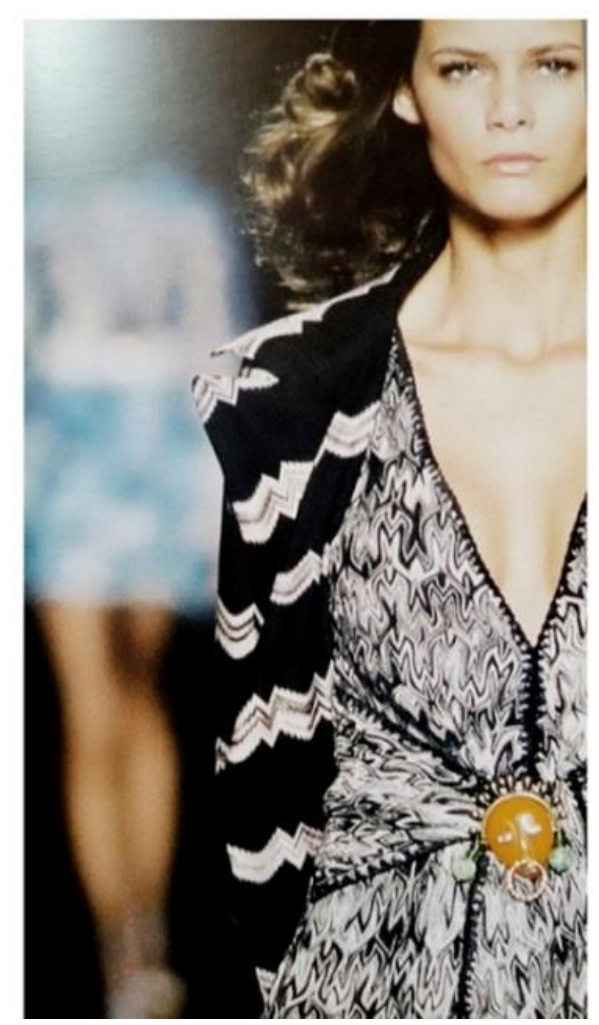

Figura 51 - Produto da marca Missoni. Fonte: Missoni, 2006.

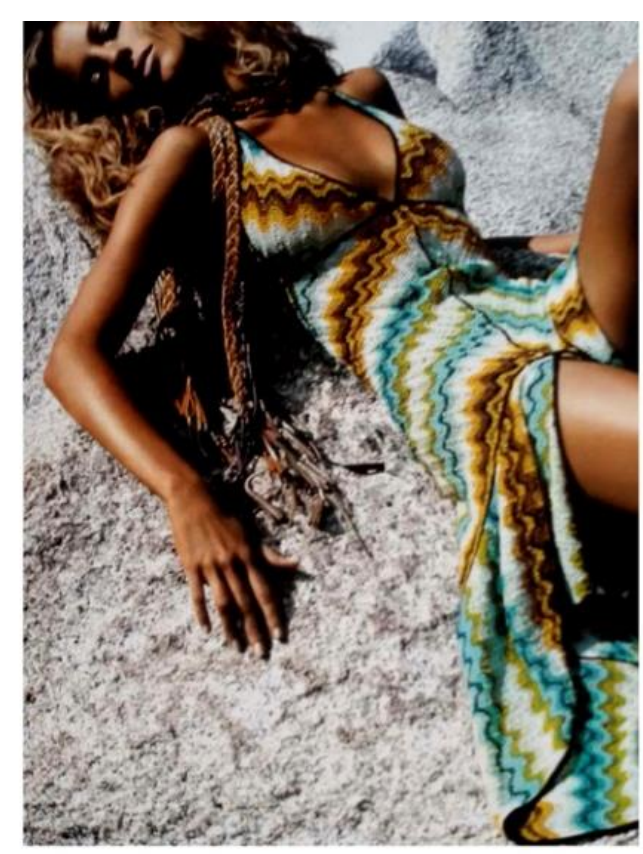

Figura 52 - Produto da marca Missoni. Fonte: Missoni, 2006.

Palavras de Ottavio Missoni (Missoni, 2006, p.17, tradução nossa)

"O nosso ofício se baseia em dois componentes: o potencial da matéria e também das cores, dois elementos inexauríveis, com os quais nunca acabam de se misturar". Eu 
me pergunto sempre de onde chega a minha atração e familiaridade com estas duas linguagens. Este trabalho eu aprendi somando gesto, através de prática contínua e exercícios cotidianos. Uma soma de experiências..., aquilo que eu bebi que eu conversei de noite com meus amigos, o que eu vi nas viagens, nos museus, nas paisagens, aquilo que amamos. Cada gesto espelha e interpreta o nosso conhecimento, o nosso modo de sentir".

Rosita Jelmini, criativa e rica de estilo, esposa de Ottavio, teve uma influência fundamental nas criações do estilo Missoni, uma linguagem geométrica e de fantasia combinadas, coordenadas, ajuntadas e sobrepostas. Um patchwork de cortes e detalhes de malha. Foi um mestre em inovação no âmbito do estilo, enquanto Ottavio se dedicava a concessão e produção de padrões e cromatismos (Missoni, p. 23).

Ottavio desenvolveu seus desenhos em papéis com aspectos bidimensionais magicamente construídos nas suas variações de composição. Um Knitwear intenso com inconfundível e infinita articulação, declinação, interação, modulação, estratificação, permutação de padrões estampados ou em listras, em ondas ou em zig zag, em conjunto ou centralizadas, em gregas, em enquadramentos ou em barrados, em círculos ou em triângulos.

Ticini, pesquisador de uma atividade que estuda o diálogo entre a Arte e a Neurociência, denominada Neuroestética, escreve sobre a obra de Missoni (MISSONI, 2006, p. 31, tradução nossa):

"A arte pictórica, a música, a literatura e a arquitetura, assim como cada atividade humana, são frutos da organização da nossa mente". São passados séculos, mas não somos ainda capazes de entender o que realmente distingue o ser criativo, o que explica que os sentimentos de amor, de ódio e até mesmo a capacidade de criar e expressar a arte refletem propriedades e leis específicas do cérebro e fica difícil interpretar cientificamente essas emoções, mas contribui para entender em um modo mais geral o trabalho de um artista. No entanto, os sentimentos de amor, de ódio e até mesmo a capacidade de criar e apreciar a arte refletem as propriedades e leis específicas do cérebro. Uma das principais revelações sobre a anatomia do cérebro foi à identificação de áreas no cérebro especializada na análise de diferentes percepções; olhando as cores de Missoni, por exemplo, se ativa uma área especializada em cores. A utilização apropriada das listras abstratas amplifica a importância das cores e as exalta, liberando as fronteiras da tensão imposta das figuras complexas e permitindo a mente viajar velozmente através dos elementos lineares. Em consequência, através das linhas, a nossa atenção se focaliza principalmente sobre a cromia, o que acontece por um motivo fisiológico: as células que extraem a forma não se interessam pelas cores da linha e separam a percepção da forma das cores. A utilização de combinações e contrastes 
das cores, reforça ou reduz o conhecimento subjetivo da obra, transmitindo sensações variáveis e contraditórias como dinamismo-estabilidade, solidez-instabilidade, clarezaambiguidade. Estas sensações resultam em harmonias diferentes, símbolos expressivos para uma ampla gama de emoções que são valores da percepção primária da cor. Essas obras expressam duas vias com percepções diferentes: a primeira ligada a análise da cor e forma e a segunda no tempo e no espaço. A percepção multissensorial é uma predisposição natural adquirida na evolução do homem. Na verdade, ligar as várias percepções que afetam o maior número de sentidos permite a obtenção de uma representação ideal de cada objeto. $\mathrm{O}$ envolvimento dos sentidos é um exemplo perceptivo que se assemelha a uma experiência sinestésica. A Sinestesia é uma forma extrema de colóquio entre as áreas do cérebro e consequentemente de criatividade. Se bem usada, as percepções sinestésicas permitem ao artista experimentar o mundo de forma extraordinária influenciando a sua criatividade na percepção das cores, sons e sabores.

Como Missoni diz "Com as cores podemos fazer aquilo que queremos, assim como com as notas musicais". Como artista, trabalhando mais em um ateliê do que no laboratório, sempre pesquisou e é um exemplo de pesquisa: observação, compreensão, documentação, revelar emoções, ritmos e cores, formas e estruturas, recolher estímulos para inventar soluções inéditas e sempre jovens.

A marca utiliza as sofisticadas máquinas de malharia retilíneas computadorizadas alemãs Stoll, ou as Japonesas Shima Seiki, como também, as máquinas Rachel, que produzem finos tecidos de malhas em correntes que oferecem uma grande variedade de efeitos e desenhos (MISSONI, 2006, p. 43). A seguir as peças de malhas apresentadas na coleção 2012.

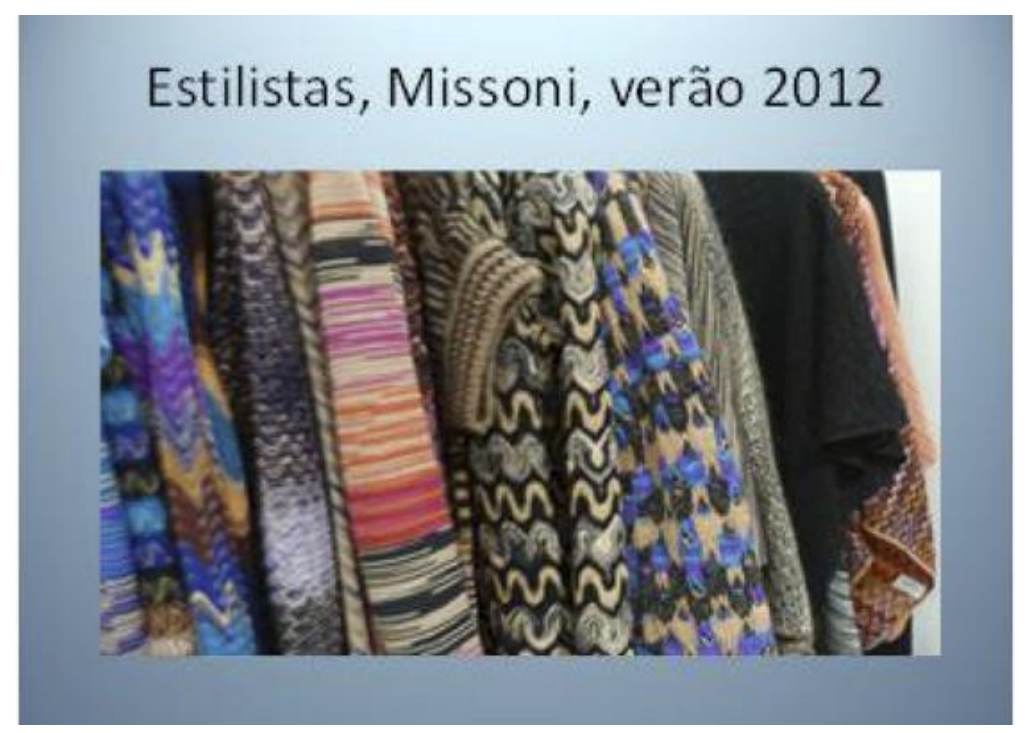

Figura 53 - Moda em vestuário de malharia retilínea, padronagens da marca Missoni, coleção 2011. 


\subsubsection{Issey Miyake}

Issey Miyake começou em 1970 como designer no estúdio em Tóquio onde adotou os novos tecidos como as malhas de Jérsei, com fibras de poliéster e de acrílico. Nascido no Japão, esse estilista está sempre pesquisando a tecnologia têxtil, o que permite ter resultados que transcendem os convencionais parâmetros da moda (FOGG, 2010, tradução nossa)

Esse designer inovou ao utilizar uma técnica de tecimento em malharia retilínea denominada A-POC, criada em conjunto com o engenheiro têxtil. Daí Fujiwara em 1999. Esse sistema de tecer foi criado para produzir uma peça pronta de máquina para vestir, sem descarte e com um mínimo de corte.

Com desenvolvimentos posteriores, a peça de tecido foi construída a partir de tubos de malha sem costura, evitando cortes. Se o tecido for cortado, as fibras mais elásticas na camada inferior tendem a encolher, por isso, é tecida uma terminação nas extremidades, evitando que desfiem e apertem a malha. Na figura a seguir, um exemplo de técnica A-POC, construção de vestido sem costuras em formas tubolares:

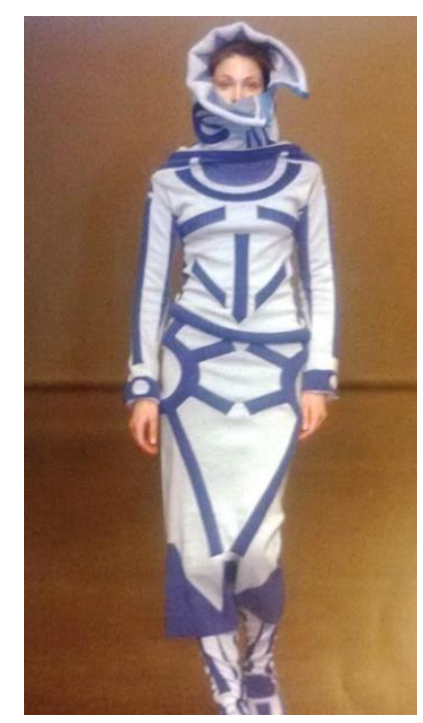

Figura 54 - Modelo tubolar sem costuras baguette design coleção ano 2000, Issey Miyake. Fonte: Fogg, 2010.

O projeto A-POC de Issey Miyake impõe que se reflita sobre a produção de vestuário no século XXI. O tubo de malha sem costura é produzido numa máquina de malhas e contém todas as peças de roupa necessárias para uma coleção coordenada, prontas para serem cortadas e customizadas pelo consumidor, podendo escolher o comprimento e a forma das peças (LEE, 2005). 


\section{Estudo da aplicabilidade de métodos de desenvolvimento de produto da engenharia para o VMMR}

Alguns métodos de elaboração de um projeto de produto em engenharia que podem contribuir para o processo de criação e desenvolvimento do produto de VMMR. O estudo dos métodos em engenharia é uma base de conhecimento amplamente aplicável a outros campos, como o de moda, pois permite a divisão do processo de criação em etapas, o que tende a estruturar conceitos.

Segundo Munari (2002),

"O método de um projeto não é mais do que uma série de operações necessárias, dispostas em ordem lógica, ditada pela experiência (...). Não se deve projetar sem um método, pensar de forma artística procurando logo a solução, sem fazer antes uma pesquisa sobre o que já foi feito de semelhante ao que se quer projetar, sem saber que materiais utilizar para a construção, sem ter definido bem a sua exata função".

Na malharia retilínea é necessário detalhar minuciosamente o produto com todas as especificações técnicas, indicar os recursos a serem usados, matérias-primas, especificação de pontos, medidas e regulagens da máquina a fim de elaborar os documentos do projeto. Além da utilização dos recursos técnicos de programação, como o CAD-CAM e as amostras, também, são modificadas com aplicação manual de novos elementos visuais. As informações destas etapas a serem cumpridas devem ser inseridas na ficha técnica de acordo com o processo de aprovação do desenvolvimento de produto de VMMR.

Os dois métodos em engenharia estudados e pesquisados são Método MAPP-3A Mello (2011) e Método PRODIP - Silva (2008).

\subsection{Método MAPP-3A - Mello (2011)}

Este método, também denominado método aberto de projeto de produto propõe três alternativas para a criação de um produto. Sua proposta tem como foco um projeto que seja aplicado ao desenvolvimento de um produto no meio acadêmico em engenharia. Mello estuda algumas metodologias científicas com o intuito de propor um método estrutural que estimule interferências no decorrer do projeto. $\mathrm{O}$ autor apresenta, como exemplo, um método de design 
em um projeto de dispositivo de conforto térmico, que seja integrado ao mobiliário, de modo que estética e forma possam valorizar o ambiente; de fácil manuseio, o método também se preocupa com o baixo custo de fabricação. Ele escolheu alguns estudos para aplicar uma matriz de decisão e chegar a um conceito da melhor solução de design.

A partir de estudos de vários métodos, Mello propõe o método MAPP-3A. Ele desenvolveu um planejamento de produto que é representado com um círculo radial expandido, conforme a figura 56, baseado no briefing do produto com inovação tecnológica. Nesse método, cada etapa é constituída por uma lista de atividades e objetivos a serem atingidos; ele é sequencial no tempo, no desenvolvimento e na atenção. O método passa por entender as funções predeterminadas nas disciplinas de gerenciamento, princípios básicos de custos e organizações de negócios. O método MAPP-3A: A partir dos estudos de vários métodos analisa o produto com apelo estético como é o caso do vestuário em que os atributos técnicos de construção do produto interferem diretamente na sua aparência e no seu consumo. Estes atributos estéticos foram divididos neste trabalho em sensorial, simbólico e estilo. Os aspectos sensoriais são detectados pelos nossos cinco sentidos como a cor, forma, sabor, contato e perfume. Os fatores simbólicos referem-se a significados ou a aparência do produto, pesado, inteligente, veloz; e estilo que se refere à época, moderno, realista.

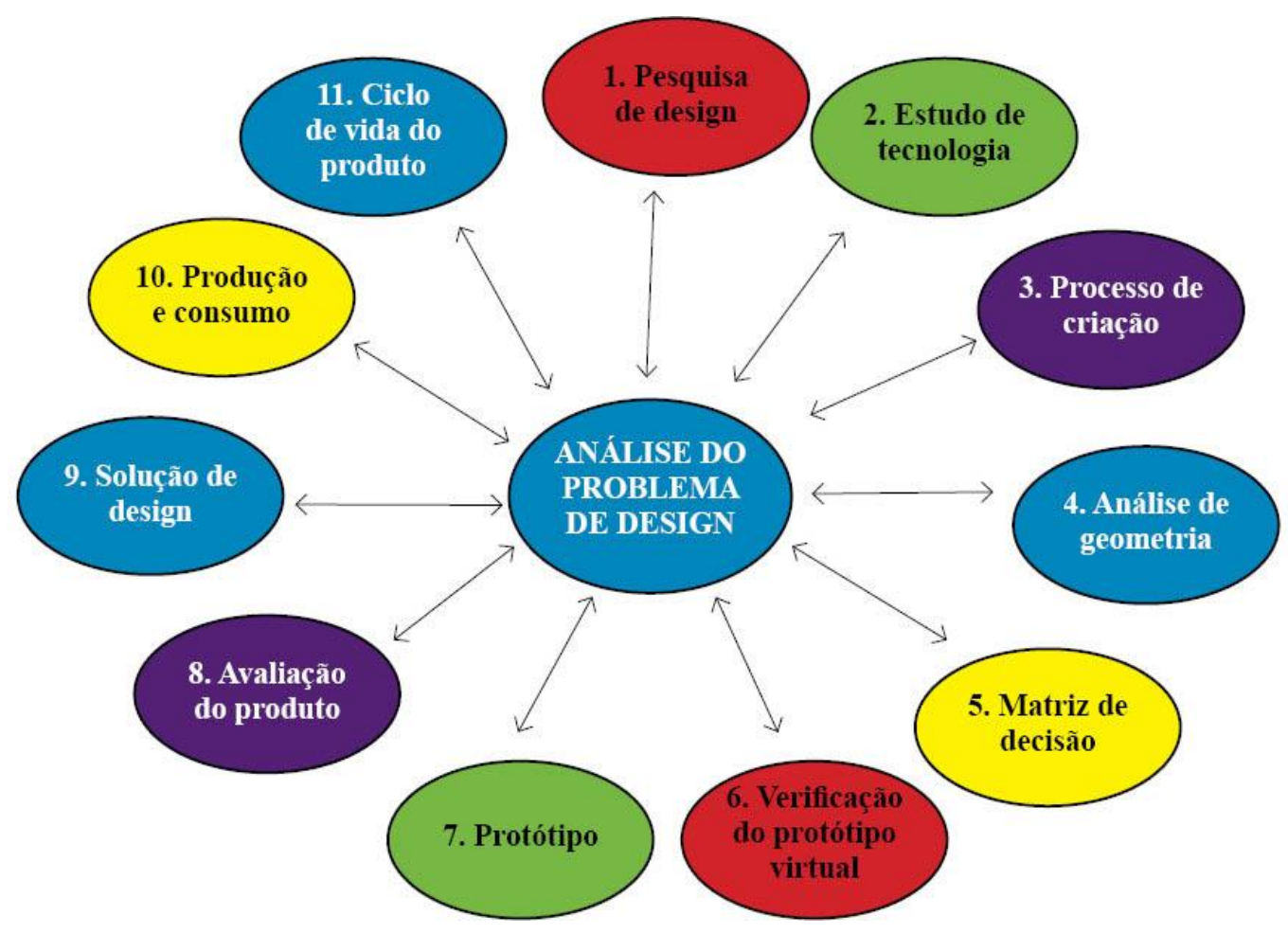

Figura 55 - Modelo MAPP-3A. Método desenvolvido por Mello, (2011). 
Vários métodos influenciaram a construção do MAPP-3A, e os métodos que mais se destacaram nesta proposta de desenvolvimento de produto foram:

1. Pugh e Money (1998) - lista de verificação e inter-relação em cada etapa.

2. Pahl e Beitz (1996) - divisão de tarefas.

3. Munari (2002) - alternativas e formas de criação.

\subsubsection{Métodos Pugh e Money (1998)}

Nesta metodologia o projeto começa e termina no mercado, valorizando as informações do mercado nas decisões de projeto entre etapas. Tal desenvolvimento de produto tem como premissa integrar a psicologia social dos grupos, com trabalhos no campo do design e da engenharia. Ele estuda pessoas, atividades, processos e gestão com soluções em torno da estratégia do negócio. Propõe o desenvolvimento de produto em cinco fases e cinco tarefas voltadas ao mercado como mostra a figura a seguir.

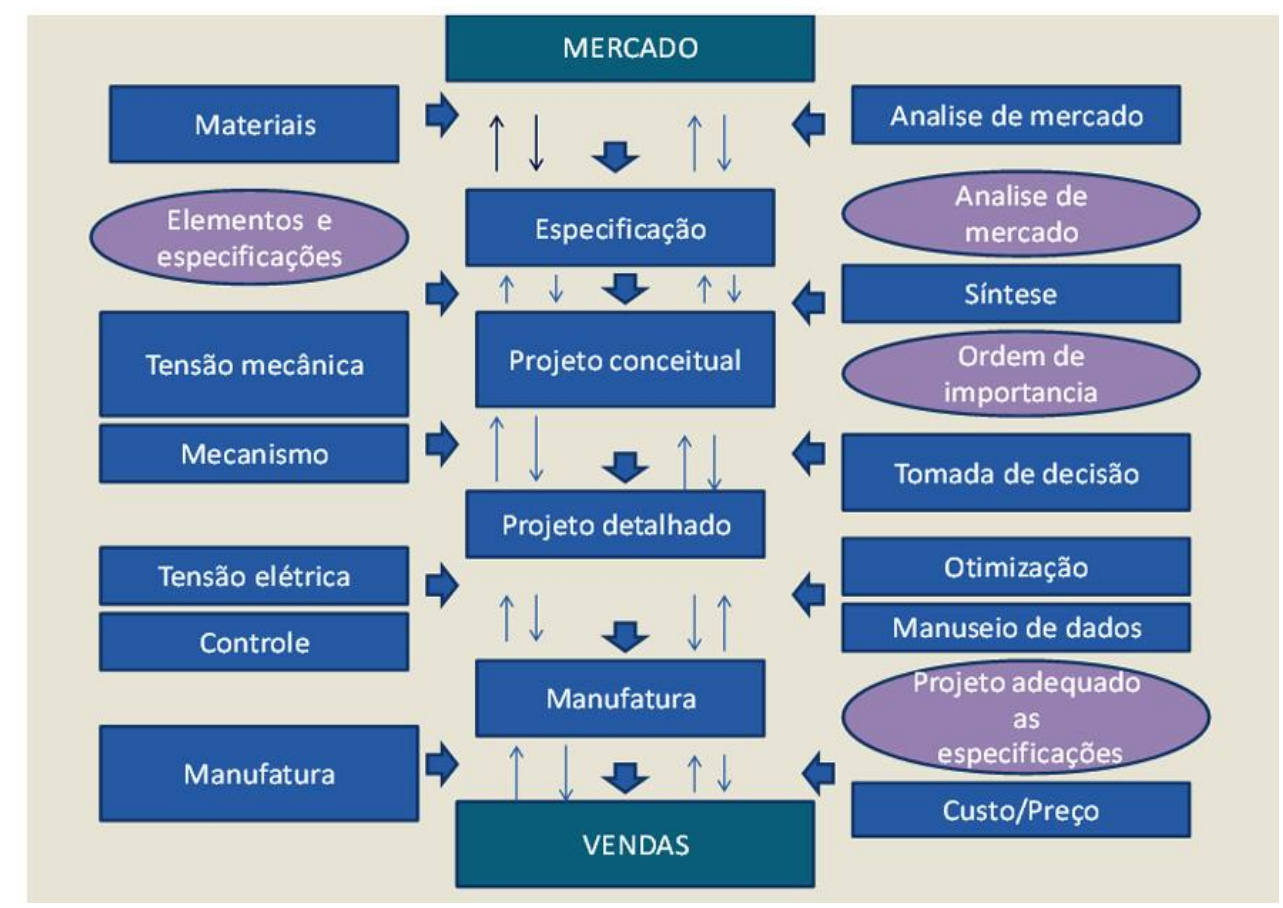

Figura 56 - Pugh e Money (1998).

Essa metodologia, analisa Mello (2011), amplia a visão de produto focado no mercado, leva em conta, principalmente, a otimização do projeto em relação aos seus custos, observando os materiais e as cinco etapas que se relacionam em via de mão dupla e em 
direção às necessidades do mercado. Cada etapa é analisada e controlada, visando solucionar o problema de manufatura do projeto de design adequando ao consumidor.

\subsubsection{Método Pahl e Beitz (1996)}

Pahl e Beitz (1996), apresentam uma metodologia de desenvolvimento de produto em quatro fases de tarefas: Clarificação das necessidades, Projeto conceitual, Projeto Preliminar, Projeto Detalhado. Conforme figura a seguir:

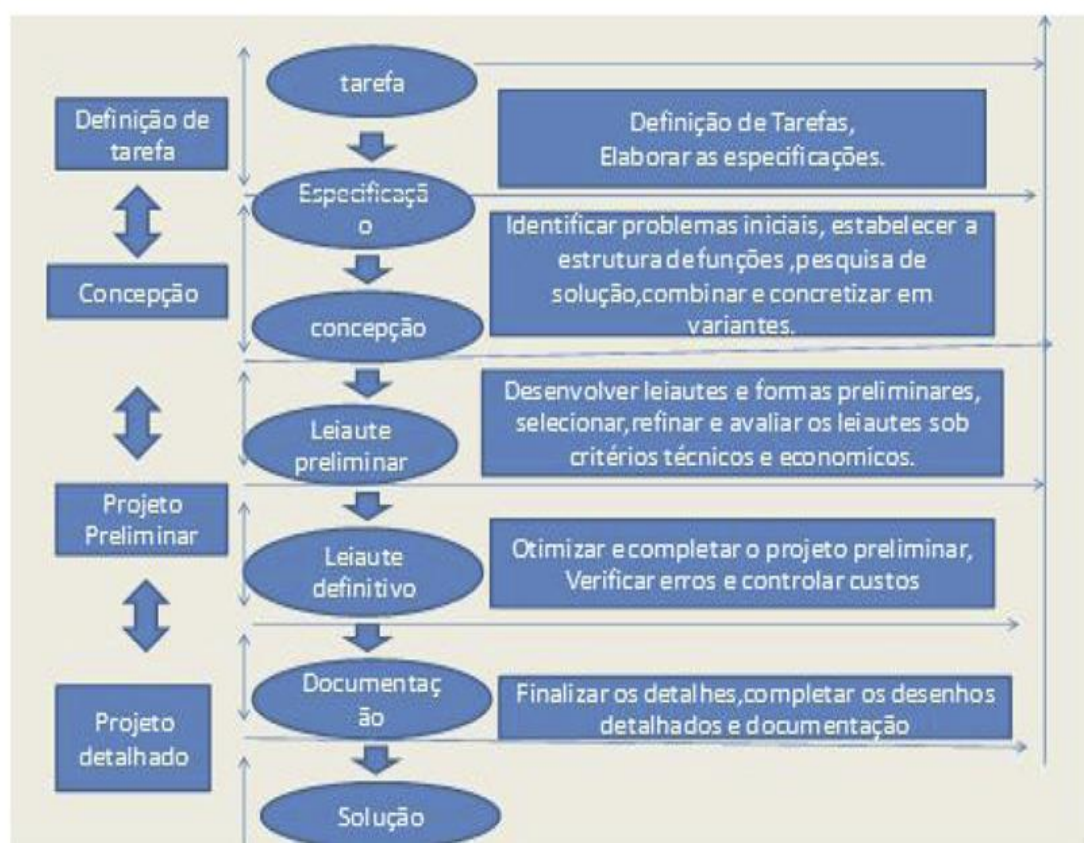

Figura 57 - Pahl e Beitz (1996).

Neste modelo de desenvolvimento de produto é feito, em primeiro lugar, uma pesquisa para entender as necessidades do usuário, resultando em um estudo chamado de briefing, para direcionar as ações e dar direção à forma e ao uso do produto. Tem-se nessa fase o levantamento de dados, a definição de alternativas, o modelo virtual em 3D, a prototipagem, avaliação e acompanhamento de produção, consumo e ciclo de vida do produto. São importantes, assim como a representação gráfica para execução e fabricação das normas, patentes e outros. Essas tarefas têm um sistema dinâmico e em constante mudança durante a elaboração do projeto de desenvolvimento do produto. Os autores Pahl e Beitz, propõem as bases para desenvolver um sistema de projeto auxiliado por computador aplicando a fase de projeto conceitual. 
Mello (2011) estudou este método e faz uma análise, "Esta proposta é a necessidade de uso por parte do projetista e programador da capacidade criativa (que fazer), técnica (como fazer) e o processo do projeto (quais etapas). Neste método, cada etapa é constituída por uma lista de atividades e objetivos a ser atingidos (lista de verificação), quando o processo é programado, então, ocorre à fase de documentação do produto. Os autores neste método desconsideram os aspectos comerciais do produto".

\subsubsection{Método Munari (2002)}

Munari (2002) enfatiza a necessidade de projetar para todos os sentidos além do visual, tais como condição acústica, cheiro, tato e olfato. Estudou nessa teoria o problema do processo criativo, como deve ser analisado em vários campos importantes como, por exemplo, reaproveitamento, coerência formal, iluminação, moldes e simplificação. Ele destaca ainda as áreas de conhecimento:

Ergonomia - que estuda as maneiras de melhorar as condições dos trabalhos em seu local. Nesta ciência, analisam-se os conhecimentos da anatomia humana, fisiologia e medicina do trabalho;

Biônica - que estuda os sistemas vivos para descobrir processos, técnicas e novos princípios aplicáveis à tecnologia;

Proxêmica - que é o conjunto das observações e teorias sobre o uso humano do espaço. Estuda a relação entre o indivíduo e seu ambiente, as situações de contato ou ausência entre pessoas. Como mostra a figura a seguir.

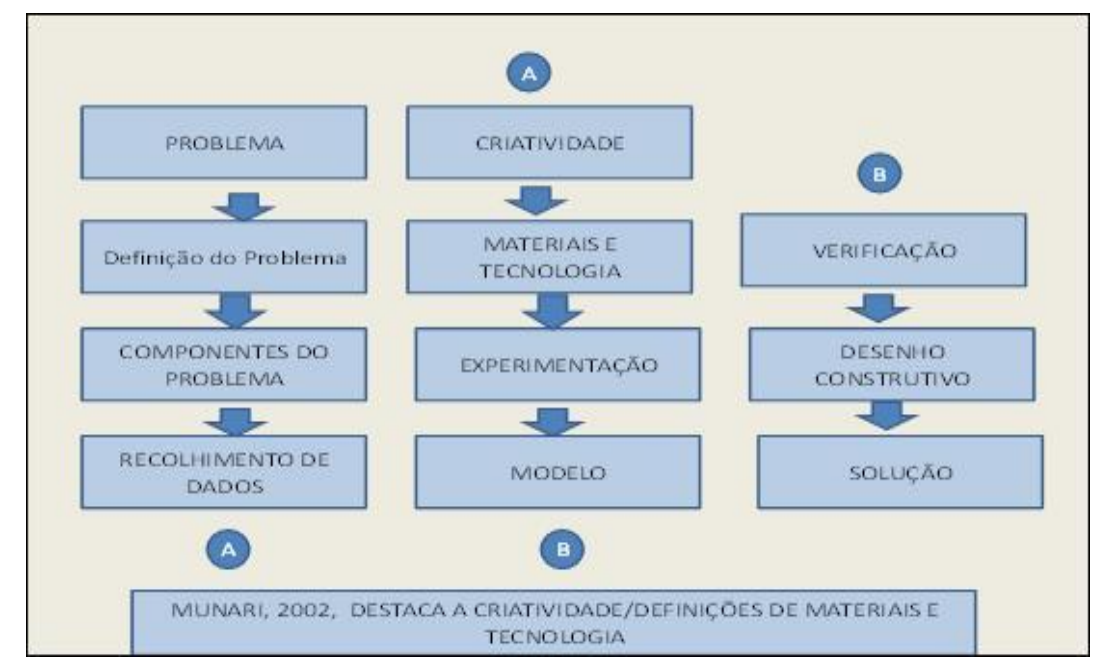

Figura 58 - Munari, destaca o processo criativo em etapas (2002). 
Mello (2011) ressalta que, o primeiro passo no processo de concepção de um produto, é fazer um desenho de esboço da ideia para, depois, aprimorar em desenhos de perspectivas e desenhos detalhados. O projeto passa a ser executado em modelos, em escalas diversas e de várias formas e materiais possíveis para tradução da ideia e de forma, que resulta em um protótipo. Após essa fase, o protótipo passa por uma análise que examina os seus aspectos em relação aos valores do gosto do consumidor e seus objetivos funcionais: fácil manuseio, cor, forma, materiais e outros mais.

\subsection{Método PRODIP - SILVA, J.C, Back. N., Ogliari. A.D. (2008)}

A proposta deste modelo de desenvolvimento integrado de produto apresenta um projeto conceitual que desenvolve alternativas de inovação do produto estudando a criatividade, levantamento de informações seleção de ideias, definição correta de ideias dentro da diversidade de conhecimentos. Segundo Silva (2008) a competitividade dos produtos depende de fatores como: escopo, custo, tempo, de lançamento e qualidade.

Neste estudo, o autor divide este método em:

- Métodos de criatividades intuitivos com as seguintes etapas: brainstorming; método Delphi; analogias; método sintético; listagens de atributos;

- Métodos Sistemáticos ou psicológicos: morfológico; análise de valor; método do princípio inventivo e síntese funcional.

Segundo Silva (2008) no Método PRODIP, os novos produtos são classificados em:

- Variantes de produtos existentes como novas embalagens, ou novas versões;

- Inovativos que tem modificações dos produtos existentes com valor agregado;

- Criativos em que os produtos se mostram com novos paradigmas e novas soluções de projeto.

O Projeto conceitual descrito pelo método PRODIP é composto por dois tipos de geração de soluções, envolvem métodos de criatividade intuitivos e sistemáticos conforme descritos na figura a seguir. O projeto conceitual descrito pelo método PRODIP é composto por dois tipos de geração de soluções - Melhoria de produtos existentes e envolvem dois tipos de métodos: criatividade intuitivo e de sistemáticos. No quadro a seguir, observa-se que, 
dentro deste sistema os que geram soluções inovadoras estão grafados em cor azul e, os que geram soluções que melhoram os produtos existentes, grafados em preto.

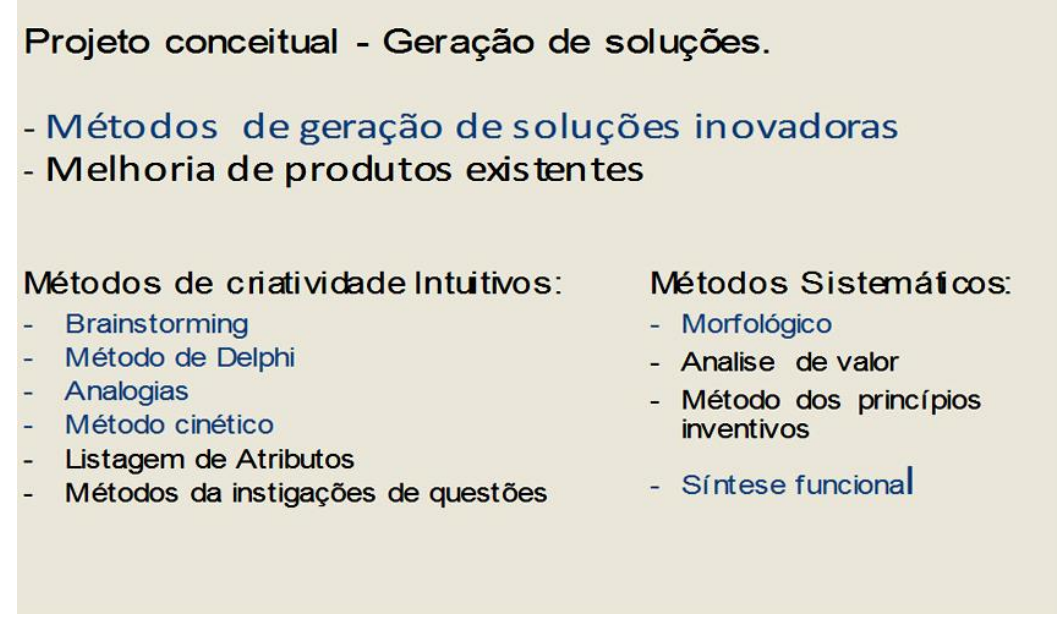

Figura 59 - Método Prodip, Silva, Back, Ogliari (2008).

\subsection{Análise dos métodos apresentados e aplicação no processo de Criação em produto de VMMR.}

Mello (2011), no MAPP-A3, passa a ideia de que um produto com um conceito bom de estética, significa ter um conjunto harmonioso nas formas, cores, matérias, acabamentos, usabilidade e outros atributos que valorizem o produto. Nesse primeiro método, é necessário detalhar minuciosamente o produto com todas as especificações técnicas, indicar os recursos a serem usados como, por exemplo, matérias-primas, pontos, medidas; a fim de elaborar a sua ficha técnica.

Aplicando as metodologias estudadas de Munari (2002), percebe-se que o produto de vestuário deve ter a modelagem adequada a ser estudada e desenvolvida sob o ponto vista ergonômico. Outro fator relevante é o toque do tecido, deve ser macio e com propriedades de conforto e proteção para o indivíduo. Munari procura resolver o problema de design, eliminando tudo o que é desnecessário, porém, simplificar exige um conhecimento profundo das necessidades a serem satisfeitas, pois corre-se o risco de não satisfazer a vontade do consumidor.

No segundo método apresentado, PRODIP, Silva (2008), propõe que desenvolver produtos industriais e gerenciar o seu desenvolvimento, se faz com uma equipe integrada e interdisciplinar. O método PRODIP considera todos os elementos do ciclo de vida do produto, 
tendo como objetivo desenvolver o projeto utilizando uma equipe multifuncional com o objetivo de aumentar a qualidade do produto, reduzir tempo de produção e custo.

$\mathrm{Na}$ malharia retilínea é necessário detalhar minuciosamente o produto com todas as especificações técnicas, indicar os recursos a serem usados - matérias primas, pontos, medidas - a fim de elaborar os documentos do projeto. Além da utilização dos recursos técnicos de programação, as amostras também podem ser modificadas com aplicação manual de novos elementos visuais, tais como fitas, drapejados; conseguidos com a utilização de elásticos, bordados e pinturas. 


\section{Estudo de Casos}

Com o objetivo de conhecer os processos criativos e de desenvolvimento de produtos no Polo do Sul de Minas Gerais de Vestuário de Moda de Malharia Retilínea (VMMR), foram realizadas entrevistas com dez fabricantes de malhas retilíneas e quatro empresas que são referências na área técnica neste polo industrial, entre as quais duas são os fornecedores de equipamento (máquinas) Stoll e Shima; uma é um escritório comercial de fios importados de vários países, e outra é uma consultoria de desenvolvimento de produto.

As entrevistas foram realizadas, em uma primeira fase, com perguntas abertas, respeitando um roteiro pré-estabelecido, a fim de estimular os entrevistados a descrever os processos com mais liberdade e criatividade nos detalhes. Este roteiro explorou, principalmente, os seguintes aspectos das empresas:

- Processo de desenvolvimento de produtos - Concepção criativa incluindo pesquisa de tendências e estilo, seleção de matérias-primas, desenho de estilos, modelagem, programação e avaliação do processo produtivo.

- Porte e Infraestrutura - quantidade de funcionários, tempo de atividade, capacidade de produção, maquinário e tecnologia utilizada na produção.

- Posicionamento Mercadológico - canais de comercialização, perfil de produtos, preço médio das peças, público-alvo.

- Profissionais envolvidos na elaboração de novos produtos (estilista, modelista, programador) e seus níveis de especialização.

Posteriormente à fase aberta, foram realizadas perguntas direcionadas a um esquema formulado com base nos métodos de desenvolvimento de produto estudados previamente neste trabalho, conforme mostra a figura a seguir. 


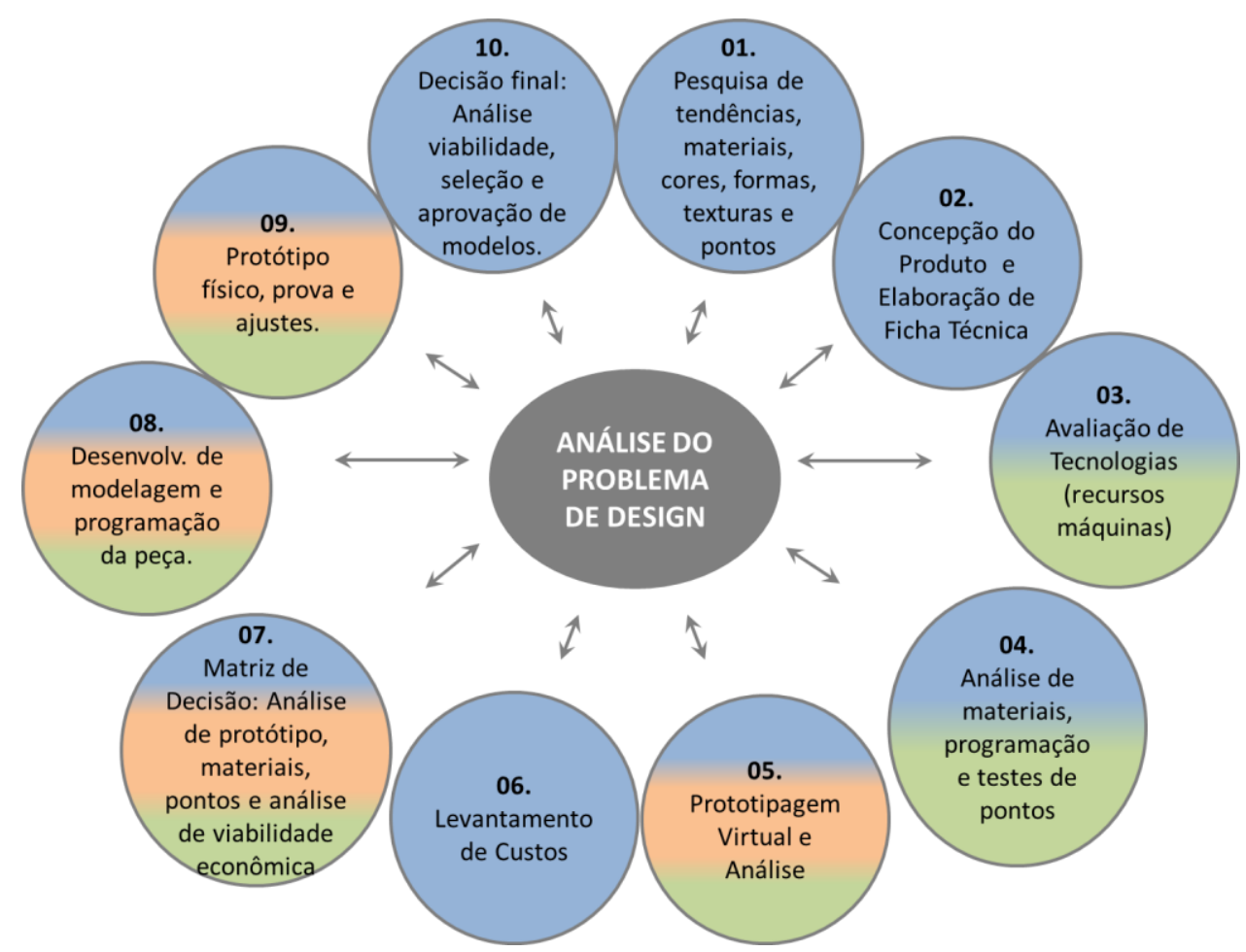

Figura 60 - Processo de desenvolvimento de produtos do VMMR Radial (elaboração da autora), baseado no modelos MAPP-3A, utilizado como base para o roteiro de perguntas direcionadas. Fonte: MAPP-3A, 2010.

As áreas 01, 02, 06 e 09 (azul) são responsabilidade do estilista ou designer de produto; as áreas 03 e 04 (verde) são do programador de máquina com interferência do estilista; e as áreas 05, 07 e 08 (rosa) unem estilistas, programadores e modelista.

A fase 01 consiste na busca de inspiração para o processo criativo, que pode ser muito conceitual, com base em fontes inclusive externas à moda propriamente dita (arte, arquitetura, história, manifestações culturais, etc.) ou em fontes mais literais, como desfiles, revistas, imagens de outros produtos. Porém, sempre passa pela pesquisa de materiais, uma etapa chave para o design. Empresas ou estilistas mais influentes podem, inclusive, influenciar outras etapas da cadeia através do desenvolvimento conjunto com fiações, para atingir objetivos específicos de materiais.

A fase 02 consiste na concepção do produto e elaboração da ficha técnica. Esta etapa é mais específica do que a fase 01 , já que envolve o desenho do produto e definição de suas diversas características técnicas desejadas (pontos, formas, volumes, etc.).

A fase 03 é a análise da tecnologia disponível, ou seja, qual maquinário poderá ser utilizado para atingir os objetivos especificados na fase 02. Esta fase é, a princípio, analisada como uma etapa posterior à criação com o intuito de preservar a liberdade e criatividade do estilo. 
A fase 04 envolve a seleção de materiais, dentre todos os pesquisados anteriormente, e a definição de pontos com base nas tecnologias disponíveis, e é seguida pela fase 05 , na qual é realizado o protótipo virtual em software especializado. Este protótipo tem o propósito de reduzir resultados indesejados, economizando custos de prototipagem real.

Com base no protótipo virtual também já é possível estudar os custos de produção (fase 06), permitindo aos profissionais de negócio atuarem junto à equipe de design para garantir a viabilidade comercial do modelo proposto (fase 07 ).

Os modelos com viabilidade comprovada passariam para a fase 08 , de desenvolvimento de modelagem e programação, e fase 09, de prototipagem física. Estas duas etapas demandam envolvimento de todos os profissionais do processo de desenvolvimento de produto, o que as tornam especificamente dispendiosas de atenção e tempo.

O processo de prototipagem e ajustes do produto ocorre de forma interativa, seguindo as interações de protótipo-prova-ajustes, novo protótipo-prova-ajustes, até que seja atingido o resultado esperado ou que o modelo seja cancelado. O processo de decisão final sobre a continuidade ou não de modelo corresponde à fase 10, e considera aspectos estéticos, funcionais e de viabilidade produtiva, de suprimentos, financeira e comercial.

Este roteiro direcionado foi elaborado com a proposta de permitir uma análise estruturada do processo de desenvolvimento de produtos, compreendendo quais fases são realizadas pelas empresas, suas respectivas sequências e importâncias no resultado final de produto, bem como adequação às necessidades da estratégia da empresa.

Além disso, também possibilita a comparação entre as empresas e divisão nas áreas de responsabilidade profissionais mais relevantes: estilo, programação e modelagem. 


\subsection{Fabricantes de produto de VMMR no Polo Industrial do Sul de Minas Gerais}

A etapa da pesquisa de estudo de casos em fabricantes de produto de VMMR no Polo do Sul de Minas Gerais, envolveu a visita às instalações industriais e a entrevista de profissionais de dez empresas, que serão tratadas neste documento apenas como EMPRESA A, EMPRESA B, e assim por diante, com o objetivo de manter em sigilo o nome das empresas.

Foram reunidas informações coletadas durante as pesquisas de observações e as entrevistas realizadas com as empresas e profissionais da área de produto VMMR (entrevistas transcritas em anexo).

As principais informações foram divididas em três áreas, conforme tabela a seguir.

Tabela 1 - Estudo de Casos.

\section{EMPRESA A}

\begin{tabular}{|c|c|c|}
\hline $\begin{array}{c}\text { PORTE E } \\
\text { INFRAESTRUTURA }\end{array}$ & $\begin{array}{l}\text { POSICIONAMENTO } \\
\text { MERCADOLÓGICO }\end{array}$ & $\begin{array}{c}\text { DESENVOLVIMENTO } \\
\text { DE PRODUTO }\end{array}$ \\
\hline $\begin{array}{l}\text { Empresa pequena com produção } \\
\text { própria em Monte Sião ( } 30 \\
\text { funcionários na planta industrial) } \\
\text { e loja de venda atacado e varejo } \\
\text { (três funcionários). Infraestrutura } \\
\text { com nove máquinas retilíneas } \\
\text { automáticas, além de máquinas } \\
\text { reta, overloque, remalhadeira, } \\
\text { botoneira, travete, ilhós, entre } \\
\text { outras. Utiliza mão-de-obra } \\
\text { especializada para trabalhos } \\
\text { artesanais. }\end{array}$ & $\begin{array}{l}\text { Marca própria de produtos de alta } \\
\text { qualidade e diferenciação } \\
\text { (feminino), venda de atacado com } \\
\text { marca própria através de } \\
\text { representantes para todo o Brasil, } \\
\text { para lojas multimarcas. Possui uma } \\
\text { loja de atacado e varejo em Monte } \\
\text { Sião. Produtos de alto valor } \\
\text { agregado. Mix de produtos: } 10 \% \\
\text { vanguarda de altíssimo valor } \\
\text { agregado, 30\% fashion, } 60 \% \text { básico } \\
\text { (mas, elaborado). Acredita na } \\
\text { pesquisa e diferenciação para } \\
\text { manter os bons resultados que vem } \\
\text { obtendo nos últimos anos. }\end{array}$ & $\begin{array}{l}\text { Processo de Criação: Pesquisa } \\
\text { através de viagens, sites (ex. } \\
\text { WGSN) e revistas > definição do } \\
\text { mix > desenho de croquis / } \\
\text { elaboração da ficha técnica > } \\
\text { definição de fios e teste de pontos > } \\
\text { modelagem > programação > } \\
\text { pilotagem > prova e estudo de } \\
\text { tempo de produção (foco em } \\
\text { produtos diferenciados e } \\
\text { elaborados) > ajuste. } \\
\text { Equipe de criação: A empresa } \\
\text { pertence a duas sócias (mãe e filha), } \\
\text { de forma que a Diretora Geral } \\
\text { também realiza a atividade de } \\
\text { estilista e modelista, com o auxílio } \\
\text { de uma modelista. A outra sócia } \\
\text { complementa o papel de estilista. } \\
\text { Além das duas sócias, a empresa } \\
\text { conta com um programador em } \\
\text { tempo integral. }\end{array}$ \\
\hline
\end{tabular}




\section{EMPRESA B}

\begin{tabular}{|c|c|c|}
\hline $\begin{array}{c}\text { PORTE E } \\
\text { INFRAESTRUTURA }\end{array}$ & $\begin{array}{l}\text { POSICIONAMENTO } \\
\text { MERCADOLÓGICO }\end{array}$ & $\begin{array}{c}\text { DESENVOL VIMENTO DE } \\
\text { PRODUTO }\end{array}$ \\
\hline $\begin{array}{l}\text { Empresa familiar de médio porte, } \\
\text { cujas três sócias são irmãs. Conta } \\
\text { com história de } 15 \text { anos de } \\
\text { atividade, } 100 \text { funcionários, e } \\
\text { produção } 50 \text { mil peças/mês. } \\
\text { Infraestrutura industrial com } 28 \\
\text { máquinas retilíneas, além de } \\
\text { máquinas de costura. Subcontrata } \\
\text { parte da produção de costura } \\
\text { (para mix de tecidos planos e } \\
\text { malhas circulares). } \\
\text { Planta industrial em Águas de } \\
\text { Lindóia; e três lojas, duas em } \\
\text { Monte Sião e uma (matriz - } \\
500 m 2 \text { ) em Águas de Lindóia. }\end{array}$ & $\begin{array}{l}\text { Venda através de lojas próprias } \\
\text { (atacado e varejo), e de } \\
\text { revendedores autônomos por todo o } \\
\text { território nacional. } \\
\text { Produto para o público feminino, } \\
\text { voltado para classes B e C. } \\
\text { A venda de produtos de retilínea é } \\
\text { fortemente sazonal, voltada para } \\
\text { blusas e casacos no inverno. No } \\
\text { verão, o mix de produtos é mais } \\
\text { voltado para peças de malharia } \\
\text { circular e tecido plano, com apenas } \\
\text { uma pequena parcela de blusas de } \\
\text { malharia retilínea. }\end{array}$ & $\begin{array}{l}\text { Equipe de criação composta pelas } \\
\text { três sócias, que coordenam a função } \\
\text { comercial e de estilo. Uma das } \\
\text { sócias tem capacitação em } \\
\text { modelagem. Além das sócias, } \\
\text { contam com uma pequena equipe de } \\
\text { assistentes de estilo e modelagem, e } \\
\text { três programadores em período } \\
\text { integral. Na formação societária } \\
\text { original, existiam dois sócios } \\
\text { adicionais, dos quais um atuava } \\
\text { como programador. } \\
\text { Com a alteração societária, o } \\
\text { processo de programação passou a } \\
\text { ser profissionalizado por } \\
\text { funcionários com alto nível de } \\
\text { treinamento e especialização em fios } \\
\text { e pontos, inclusive com } \\
\text { conhecimentos básicos de } \\
\text { modelagem para retilínea. } \\
\text { Utiliza-se fontes externas à empresa, } \\
\text { no processo de criação, como } \\
\text { agências de pesquisa de tendência e } \\
\text { estilistas locais. }\end{array}$ \\
\hline
\end{tabular}

\section{EMPRESA C}

\begin{tabular}{|c|c|c|}
\hline $\begin{array}{c}\text { PORTE E } \\
\text { INFRAESTRUTURA }\end{array}$ & $\begin{array}{l}\text { POSICIONAMENTO } \\
\text { MERCADOLÓGICO }\end{array}$ & $\begin{array}{c}\text { DESENVOLVIMENTO DE } \\
\text { PRODUTO }\end{array}$ \\
\hline $\begin{array}{l}\text { Empresa pequena de Monte Sião, } \\
\text { com quase } 32 \text { anos de atividade, } \\
\text { comprada pelo atual proprietário } \\
\text { há } 23 \text { anos. Conta com uma } \\
\text { planta industrial e três lojas na } \\
\text { cidade. }\end{array}$ & $\begin{array}{l}\text { Empresa atua com marca própria } \\
\text { (feminino e masculino), mas } \\
\text { principalmente fornecendo a outras } \\
\text { marcas (Private Label), a uma } \\
\text { quantidade média de } 500 \\
\text { peças/modelo (dividas em } 2 \text { ou } 3 \\
\text { cores). O perfil de produtos é de alta } \\
\text { qualidade e diversificação. O } \\
\text { empresário acredita que uma } \\
\text { estratégia para a distinção no } \\
\text { mercado é de disponibilizar mais } \\
\text { modelos com quantidades menores. }\end{array}$ & $\begin{array}{l}\text { O sócio-proprietário, além das } \\
\text { funções de gestão, também acumula } \\
\text { a pesquisa de materiais, } \\
\text { desenvolvimento de produto e } \\
\text { programação, com o auxílio de sua } \\
\text { esposa na modelagem e de um } \\
\text { programador com dedicação parcial. } \\
\text { Os modelos desenvolvidos para as } \\
\text { marcas são criados pelos estilistas } \\
\text { dos clientes. }\end{array}$ \\
\hline
\end{tabular}




\section{EMPRESA D}

\begin{tabular}{|c|c|c|}
\hline $\begin{array}{c}\text { PORTE E } \\
\text { INFRAESTRUTURA }\end{array}$ & $\begin{array}{l}\text { POSICIONAMENTO } \\
\text { MERCADOLÓGICO }\end{array}$ & $\begin{array}{c}\text { DESENVOLVIMENTO DE } \\
\text { PRODUTO }\end{array}$ \\
\hline $\begin{array}{l}\text { Empresa familiar de três sócios, } \\
\text { atuante há mais de } 10 \text { anos em } \\
\text { Monte Sião. Estrutura com } 10 \\
\text { funcionários, } 3 \text { máquinas } \\
\text { eletrônicas e algumas máquinas } \\
\text { manuais. }\end{array}$ & $\begin{array}{l}\text { Venda de atacado (pronta-entrega) } \\
\text { através de atacadistas. } \\
\text { Produtos simples e básicos, mix } \\
\text { quase integralmente composto por } \\
\text { blusas de inverno abertas ou } \\
\text { fechadas com decote } \mathrm{V} \text { ou careca, } \\
\text { feminino e masculino. } \mathrm{O} \text { foco } \\
\text { mercadológico é baixo preço, } \\
\text { padronização de produtos, e } \\
\text { produtividade. }\end{array}$ & $\begin{array}{l}\text { O processo de criação é muito } \\
\text { rudimentar e não conta com equipe } \\
\text { dedicada permanente, por se tratar } \\
\text { de um produto padronizado que não } \\
\text { sofre alterações relevantes entre } \\
\text { coleções. A programação não sofre } \\
\text { grandes variações e, quando precisa } \\
\text { ser alterada, utilizam a infraestrutura } \\
\text { da Stoll (fonte dos equipamentos } \\
\text { utilizados pela empresa). } \\
\text { A tecelagem é feita em painéis com } \\
\text { punho que, posteriormente, são } \\
\text { cortados como no processo de } \\
\text { tecido plano. }\end{array}$ \\
\hline
\end{tabular}

\section{EMPRESA E}

\begin{tabular}{|c|c|c|}
\hline $\begin{array}{c}\text { PORTE E } \\
\text { INFRAESTRUTURA }\end{array}$ & $\begin{array}{l}\text { POSICIONAMENTO } \\
\text { MERCADOLÓGICO }\end{array}$ & $\begin{array}{c}\text { DESENVOLVIMENTO DE } \\
\text { PRODUTO }\end{array}$ \\
\hline $\begin{array}{l}\text { Empresa familiar pequena na } \\
\text { cidade de Socorro, com mais de } 15 \\
\text { anos no mercado. } \\
\text { Aproximadamente } 30 \\
\text { funcionários na planta industrial. } \\
\text { A empresa também conta com } \\
\text { três lojas de atacado e varejo } \\
\text { (Socorro, Monte Sião, Serra } \\
\text { Negra), e uma loja de atacado em } \\
\text { Americana. } \\
\text { Produção aproximada de } 2 \text { a } 3 \mathrm{mil} \\
\text { peças/mês. }\end{array}$ & $\begin{array}{l}\text { Atua com coleção e marca própria e } \\
\text { também com produção para terceiro } \\
\text { (Private Label). } \\
\text { Linha de produtos masculina, com } \\
\text { qualidade e diferenciação pois } \\
\text { fabrica produtos com lavagem e } \\
\text { tingimento, nas bases de algodão cru } \\
\text { e com aplicação de materiais } \\
\text { especiais (cordões, cadarços, taxas, } \\
\text { couro, etc.). } \\
\text { Transita do público intermediário ao } \\
\text { premium. }\end{array}$ & $\begin{array}{l}\text { Processo Criativo: Pesquisa das marcas } \\
\text { alvo (Private Label) / pesquisa em lojas } \\
\text { departamentais internacionais (El Corte } \\
\text { Inglês, Harrod's) / Consultorias de } \\
\text { moda na região> Desenho dos Croquis } \\
\text { / Ficha Técnica> Seleção de fichas > } \\
\text { Escolha de materiais e pontos > } \\
\text { Modelagem > Prototipagem Virtual > } \\
\text { Análise de Produto/Custo e do } \\
\text { Protótipo Virtual (encolhimento)> } \\
\text { Programação> Pilotagem e lavagem > } \\
\text { Análise do protótipo real e seleção. } \\
\text { Equipe de criação: A sócia gestora } \\
\text { acumula a coordenação de estilo, } \\
\text { enquanto sua filha atua como estilista } \\
\text { em dedicação parcial. A sócia gestora } \\
\text { detém alguns conhecimentos de } \\
\text { programação e utiliza a infraestrutura da } \\
\text { Shima para se atualizar. Contam com } \\
\text { um programador e uma modelista } \\
\text { profissionais em dedicação integral. } \\
\text { Além de algumas peças criadas } \\
\text { internamente, adquirem desenhos de } \\
\text { estilistas locais. }\end{array}$ \\
\hline
\end{tabular}




\section{EMPRESA F}

\begin{tabular}{|c|c|c|}
\hline $\begin{array}{c}\text { PORTE E } \\
\text { INFRAESTRUTURA }\end{array}$ & $\begin{array}{l}\text { POSICIONAMENTO } \\
\text { MERCADOLÓGICO }\end{array}$ & $\begin{array}{c}\text { DESENVOL VIMENTO DE } \\
\text { PRODUTO }\end{array}$ \\
\hline $\begin{array}{l}\text { Empresa familiar de pequeno } \\
\text { porte em Monte Sião, que passou } \\
\text { por um processo de redução } \\
\text { dramática nos últimos anos, } \\
\text { eliminando a produção em } 2011 \text {, e } \\
\text { mantendo apenas quatro lojas de } \\
\text { varejo. } \\
15 \text { anos atrás, aproximadamente, } \\
\text { a empresa produzia em torno de } \\
20 \text { mil peças por modelo, contando } \\
\text { com uma infraestrutura de até } 10 \\
\text { máquinas retilíneas } \\
\text { automatizadas. }\end{array}$ & $\begin{array}{l}\text { No passado a empresa atuava como } \\
\text { fabricante de itens básicos com } \\
\text { marca própria ( } 10 \text { a } 20 \text { mil peças por } \\
\text { modelo em } 40 \text { cores), com a crise } \\
\text { identificada do mercado, passou a } \\
\text { aumentar o número de modelos, } \\
\text { porém, não conseguiu manter a } \\
\text { lucratividade. No período de maior } \\
\text { volume, a diferenciação ocorria } \\
\text { através dos materiais. } \\
\text { Atuava com marca própria e } \\
\text { desenvolvia para marcas de terceiros } \\
\text { (Private Label). } \\
\text { Atualmente apenas compra produtos } \\
\text { de outras malharias e revende nas } \\
\text { lojas com sua marca, e a empresa } \\
\text { encontra-se em fase de redução. }\end{array}$ & $\begin{array}{l}\text { Apesar da mudança mercadológica, } \\
\text { o processo criativo foi mantido, } \\
\text { pois, as produções realizadas nas } \\
\text { malharias da região, também são } \\
\text { feitas sob demanda da empresa. Por } \\
\text { outro lado, os profissionais não } \\
\text { estão mais concentrados na sua } \\
\text { empresa, uma vez que o } \\
\text { programador é do fornecedor, e o } \\
\text { estilo se baseia em estilistas } \\
\text { contratados na região. } \\
\text { A sócia é especializada em } \\
\text { modelagem, mas atualmente apenas } \\
\text { solicita alterações para os } \\
\text { fabricantes. }\end{array}$ \\
\hline
\end{tabular}

\section{EMPRESA G}

\begin{tabular}{|l|l|l|}
\hline \multicolumn{1}{|c|}{ PORTE E } & \multicolumn{1}{|c|}{ POSICIONAMENTO } & DESENVOLVIMENTO DE \\
INFAESTRUTURA & MERCADOLÓGICO & \multicolumn{1}{c|}{ PRODUTO } \\
\hline $\begin{array}{l}\text { Empresa familiar de pequeno } \\
\text { porte, que encerrou suas } \\
\text { atividades de 10 anos de mercado, } \\
\text { logo após a entrevista. Em sua } \\
\text { existência, chegou a ter mais de 30 } \\
\text { funcionários e 10 máquinas } \\
\text { retilíneas automáticas. }\end{array}$ & $\begin{array}{l}\text { Produtos básicos de qualidade para } \\
\text { público masculino e feminino, } \\
\text { incluindo lã e algodão tinturado, } \\
\text { principalmente para marcas Private } \\
\text { Label e adicionalmente com marca } \\
\text { própria, cuja comercialização era } \\
\text { feita por meio de representantes } \\
\text { (atacado, sob pedido), e uma loja de } \\
\text { fábrica (atacado e varejo). }\end{array}$ & $\begin{array}{l}\text { Durante o período de atividade, a } \\
\text { sócia atuava como estilista e } \\
\text { estilista, com uma assistente de modelagem } \\
\text { também tinha conhecimentos de } \\
\text { programação. } \\
\text { A coleção própria era desenvolvida } \\
\text { a partir da pesquisa de tendências } \\
\text { realizada pela estilista. Os croquis } \\
\text { eram feitos internamente e } \\
\text { adquiridos dos estilistas locais. } \\
\text { A maioria dos materiais era mantida } \\
\text { de uma coleção para a outra. }\end{array}$ \\
\hline
\end{tabular}




\section{EMPRESA H}

\begin{tabular}{|c|c|c|}
\hline $\begin{array}{c}\text { PORTE E } \\
\text { INFRAESTRUTURA }\end{array}$ & $\begin{array}{l}\text { POSICIONAMENTO } \\
\text { MERCADOLÓGICO }\end{array}$ & $\begin{array}{c}\text { DESENVOLVIMENTO DE } \\
\text { PRODUTO }\end{array}$ \\
\hline $\begin{array}{l}\text { Empresa familiar de pequeno } \\
\text { porte em Lindóia, que havia } \\
\text { encerrado as atividades há } 4 \text { anos } \\
\text { e estava em fase de reabertura por } \\
\text { dois dos sócios no momento da } \\
\text { entrevista, há dois anos. Nesse } \\
\text { momento de reabertura (2013), a } \\
\text { empresa contava com } 18 \\
\text { funcionários, } 9 \text { máquinas } \\
\text { retilíneas automáticas e produção } \\
\text { de quase } 100 \text { mil peças/ano. }\end{array}$ & $\begin{array}{l}\text { Produtos femininos, } \\
\text { predominantemente básicos e de } \\
\text { baixo valor agregado. Normalmente } \\
\text { compostos por fios } 100 \% \text { acrílico, } \\
\text { com alguns detalhes de moda. } \\
\text { Venda no sistema de pronta-entrega } \\
\text { através de uma loja (atacado e } \\
\text { varejo) e representantes } \\
\text { revendedores. } \\
\text { O preço médio varia de } \mathrm{R} \$ 25 \text { a } \\
\mathrm{R} \$ 45 \text { por peça. }\end{array}$ & $\begin{array}{l}\text { Uma sócia desenvolve os produtos } \\
\text { através de pesquisas em fontes } \\
\text { disponíveis na internet, sem regime } \\
\text { de coleções estruturadas. O outro } \\
\text { sócio na atividade de programação. } \\
\text { Ambos contam com o suporte de } \\
\text { uma modelista em dedicação } \\
\text { integral. } \\
\text { Desenvolvem produtos com base em } \\
\text { ficha técnica simples, realizando } \\
\text { protótipos, provas e ajustes. }\end{array}$ \\
\hline
\end{tabular}

\section{EMPRESA I}

\begin{tabular}{|l|l|l|}
\hline \multicolumn{1}{|c|}{ PORTE E } & \multicolumn{1}{|c|}{$\begin{array}{c}\text { POSICIONAMENTO } \\
\text { INFRAESTRUTURA }\end{array}$} & $\begin{array}{l}\text { DESENVOLVIMENTO DE } \\
\text { MERCADOLÓGICO }\end{array}$ \\
\hline $\begin{array}{l}\text { Empresa de Monte Sião de } \\
\text { pequeno porte, com 22 anos de } \\
\text { mercado e 20 funcionários. } \\
\text { No momento da entrevista (2013), } \\
\text { a empresa estava em fase de } \\
\text { ampliação, com a mudança para } \\
\text { um novo galpão, onde contava } \\
\text { com sete máquinas retilíneas } \\
\text { automáticas. } \\
\text { Também conta com duas lojas de } \\
\text { atacado. }\end{array}$ & $\begin{array}{l}\text { Produtos femininos básicos com } \\
\text { pequenos detalhes de moda, baixo } \\
\text { valor agregado. A base de material é é } \\
100 \% \text { acrílico com adição de alguns } \\
\text { componentes em parte da coleção } \\
\text { (ex. lurex e detalhes). } \\
\text { Venda a atacado, através de lojas } \\
\text { próprias e revendedores. }\end{array}$ & $\begin{array}{l}\text { O sócio diretor atua também como } \\
\text { programador (altamente qualificado) } \\
\text { e subcontrata a função de } \\
\text { modelagem e estilo. Os modelos são } \\
\text { desenvolvidos através de } \\
\text { reprodução de peças, obtidas em } \\
\text { fontes na internet e de compra de } \\
\text { modelos desenvolvidos por estilistas } \\
\text { locais. } \\
\text { O sócio e a modelista acompanham } \\
\text { a prototipagem, prova e ajustes. Os } \\
\text { pontos e materiais são definidos } \\
\text { pelo sócio. } \\
\text { O desenvolvimento de produtos não } \\
\text { é estruturado conforme coleções. }\end{array}$ \\
\hline
\end{tabular}




\section{EMPRESA J}

\begin{tabular}{|c|c|c|}
\hline $\begin{array}{c}\text { PORTE E } \\
\text { INFRAESTRUTURA }\end{array}$ & $\begin{array}{l}\text { POSICIONAMENTO } \\
\text { MERCADOLÓGICO }\end{array}$ & $\begin{array}{c}\text { DESENVOLVIMENTO DE } \\
\text { PRODUTO }\end{array}$ \\
\hline $\begin{array}{l}\text { Empresa familiar de pequeno } \\
\text { porte em Monte Sião, com } \\
\text { capacidade de } 20 \text { mil peças de } \\
\text { produção por ano, nove } \\
\text { funcionários e sete máquinas } \\
\text { retilíneas automáticas. }\end{array}$ & $\begin{array}{l}\text { Desenvolvem e produzem para } \\
\text { outras marcas (Private Label) e para } \\
\text { comercialização com marca própria } \\
\text { em suas duas lojas próprias (atacado } \\
\text { e varejo), e revendedores } \\
\text { atacadistas. } \\
\text { Os produtos utilizam como base os } \\
\text { fios e pontos diferenciados e } \\
\text { trabalho de estamparia, mas em } \\
\text { modelagens básicas e } \\
\text { intermediárias. O resultado final é, } \\
\text { de um produto de bom valor } \\
\text { agregado e preço intermediário. }\end{array}$ & $\begin{array}{l}\text { As coleções próprias são } \\
\text { desenvolvidas com base em } \\
\text { pesquisas na internet, palestras de } \\
\text { moda na região, viagens periódicas. } \\
\text { Um dos sócios é também um bom } \\
\text { programador e modelista, e conta } \\
\text { com o apoio de um programador } \\
\text { contratado com dedicação integral e } \\
\text { sua sócia com a perspectiva } \\
\text { comercial. } \\
\text { Não há uma grande variação de } \\
\text { modelagens, mas sim de pontos e } \\
\text { fios. }\end{array}$ \\
\hline
\end{tabular}




\subsection{Centros de referência técnica para o Polo Industrial do Sul de Minas Gerais}

Observa-se uma grande influência de agentes externos às empresas na formação do conhecimento de moda no Polo de VMMR no Sul de Minas Gerais. Deste grande grupo de agentes externos, podem-se destacar os centros de desenvolvimento e de informação dos grandes fornecedores de equipamento STOLL e SHIMA, que prestam serviços de capacitação às empresas, muitas vezes inclusos no fornecimento das máquinas.

O interesse dessas empresas é evidente, pois elas dependem do progresso de seus clientes - fabricantes de produtos VMMR - para continuar crescendo.

Além desses dois fabricantes, também se destaca a participação de um Escritório Comercial, que atua com fios importados de alta diferenciação que, para conseguir comercializar seus produtos, participa da troca de informações de maneira informal entre as empresas do Polo; e de uma empresa de consultoria de estilo e modelagem que prestou serviço para diversas empresas da região.

Neste tópico serão descritas entrevistas com essas três referências no setor no Polo do Sul de Minas Gerais, que atuam de forma mais consistente há mais de 20 anos.

\subsubsection{Fabricante de equipamentos Stoll}

Essa instituição é uma das maiores líderes mundiais no setor, e além dos recursos tecnológicos, oferece ainda real gama de valiosos serviços e avançadas consultorias de moda.

A companhia Stoll foi fundada em 27 de julho de 1873, por Heinrich Stoll, em Reutlingen, na Alemanha. Durante estes quase cento e cinquenta anos, essa empresa mostrou um espírito de alta inovação. Segundo o livro comemorativo de sesquicentenário da fundação da empresa, Heirinch Stoll foi o pioneiro na construção de máquinas retilínea. Hoje a empresa é administrada pela terceira geração, Heinz-Peter Stoll (1949) e Thomas Stoll (1943). Heinrich Stoll nasceu em 1847 e estudou mecânica. Seu primeiro contato com máquinas de malharia retilínea foi como funcionário em uma fábrica americana em grande expansão na época, chamava-se Empresa Ferdinand Grober. Essa empresa introduziu na Europa em 1870 as primeiras máquinas retilíneas. 


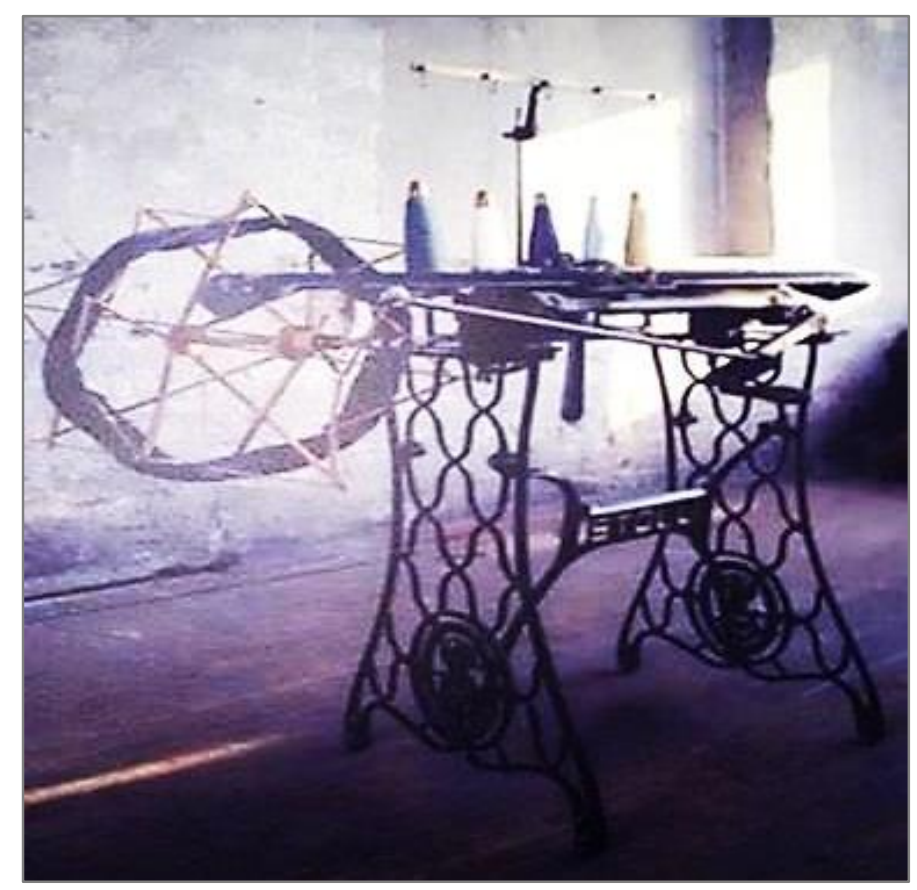

Figura 61 - Primeira máquina retilínea Stoll. Fonte: Stoll, 2008.

H. Stoll, nos primeiros anos, fez inovações nas máquinas de retilíneas manuais. Essas inovações consistiam em variar a espessura das agulhas e fios para produzir tecidos de diferentes espessuras, era o início da fabricação das máquinas que produziam tecidos de diferentes finuras ou galgas.

Em 1890, ele desenvolveu um mecanismo de dupla frontura de agulhas, com adição de controle de descarregar as agulhas. Ele patenteou este mecanismo em 1892. Outros mecanismos foram patenteados e, em 1920, começaram a produzir a base das primeiras máquinas com acionamento de motor. Nesta época, os desenhos em jacquard estampados entraram em moda e as máquinas de malharia retilínea já possuíam o sistema de diminuição de partes automaticamente, fully fashioned. Foi introduzida uma inovação, que consistia em um mecanismo para arrematar um intervalo de emenda entre o fim de uma parte e o começo da outra parte. As peças de vestuário saiam com diminuição e separadas uma das outras com terminação de canelados arrematados (punhos). Na figura a seguir, observa-se na máquina retilínea, a sequencia de partes e diminuição dos pontos em determinadas partes da peça. 


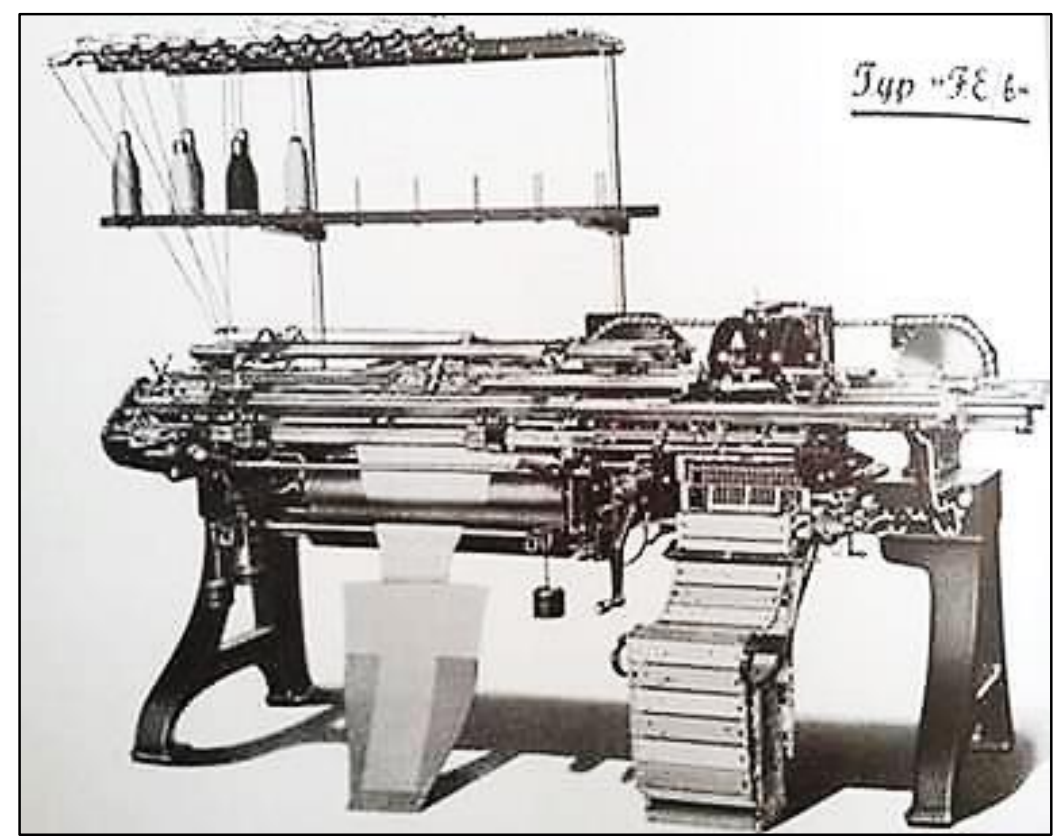

Figura 62 - Máquina retilínea 1926, STOLL. Fonte: Stoll, 2008.

Em 1975, ocorreu a apresentação da primeira máquina eletrônica controlada com programação de padrões diferenciados de cores e pontos. Na figura a seguir, máquina retilínea com seleção eletrônica de agulhas comandadas individualmente.

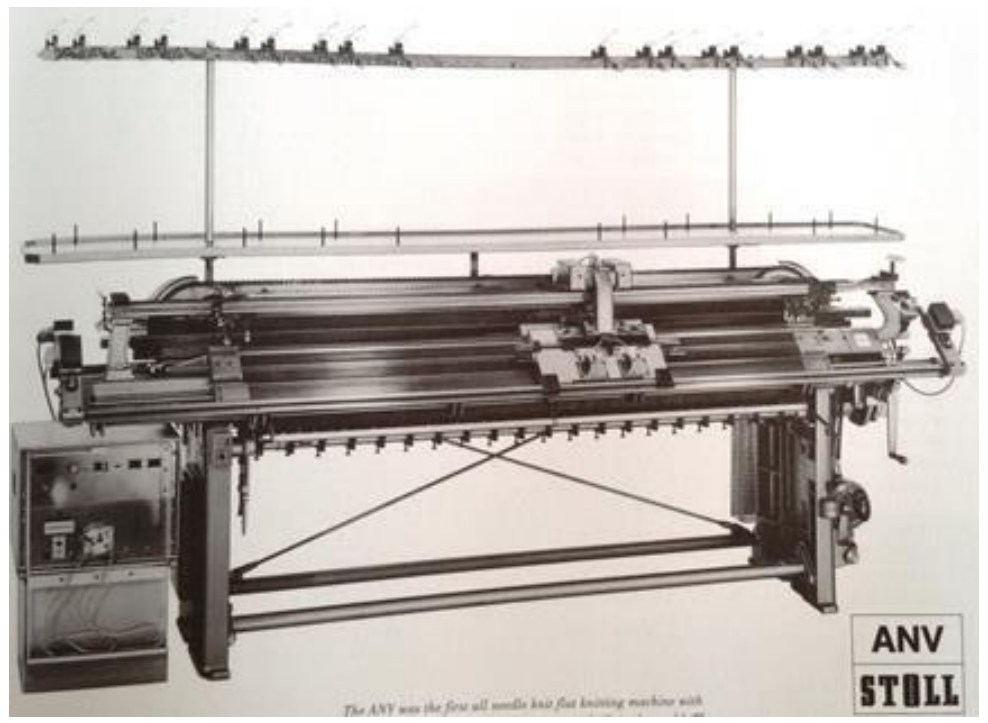

Figura 63 - Primeira máquina retilínea com seleção eletrônica de agulhas individual, lançada na ITMA, 1975. Fonte: Stoll, 2008.

Em 1987 foi desenvolvido o sistema "Fully Fashioned", de diminuição de partes da peça eletronicamente e, em 1991, o painel preparado no sistema SIRIX - Geração de 
máquinas retilínea CMS. O primeiro computador controlado de máquinas retilíneas com simulador de intarcia, gore-technique e fully fashioned.

$\mathrm{Na}$ figura a seguir, um exemplo de tecimento no sistema fully fashioned, as partes são produzidas com a modelagem pronta e com várias partes tecidas ao mesmo tempo.

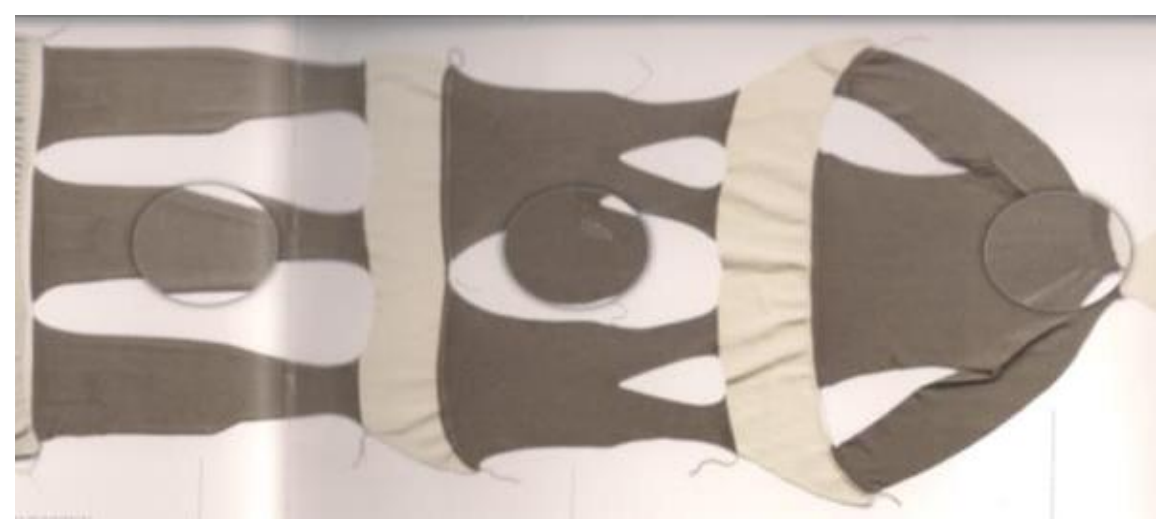

Figura 64 - Tecnologia de tecer nas máquinas as partes moldadas - fully fashioned - e sua evolução para peça pronta - Wholegarment. Fonte: Stoll, 1990.

No ano de 1999, na ITMA realizada em Paris, a Stoll apresentou a classe especial com as CMS, com ótima resposta para realizar a malha com tempos mais breves e a custos reduzidos: oferece muitas possibilidades de trabalhados com a mesma máquina e também realizar a peça pronta. (TRAINI, 2012, p.121, tradução da nossa).

As máquinas flexíveis com diferentes finuras, também denominadas multigalgas, realizam seleções individuais de agulhas, oferecem várias possibilidades para formar e reorganizar pontos individuais e grupo de pontos individuais que resultam em diferentes designs nos tecidos de malha.

As formas de fabricação, as técnicas tradicionais de cortar e costurar, a partir de um painel de tecido pronto com barra ou de paineis modelados com barra na tecnica fully fashioned, vêm sendo substituidas por máquinas retilíneas de peças prontas de máquina. Essa técnica de tecer a peça inteira pronta da máquina, que não necessita costurar, é denominada por wholegarment, ou, seamlles que significa produzir malhas sem emendas. A empresa Stoll revolucionou o mercado de máquinas têxteis, ao produzir o primeiro tear plano para malharia retilínea, continua pioneira da tecnologia de máquinas retilíneas e soluções de software para modernas técnicas de tricotagem. 
Em 2001 a Stoll apresenta os sistemas M1 - Mastersoftware e M1 plus - Workstation, o que representou grande avanço em desenvolvimento de programas computadorizados e sistemas integrados para desenvolvimento de produtos.

A figura a seguir, apresenta em duas telas como ocorre à diminuição de pontos em partes do tecido de malha, para dar forma da modelagem da peça denominada calado a partir da tecnologia fully fashioned. São duas telas na mesma mesa do programador, uma de imagem real e outra apresenta a tradução para a linguagem do programador e da máquina.

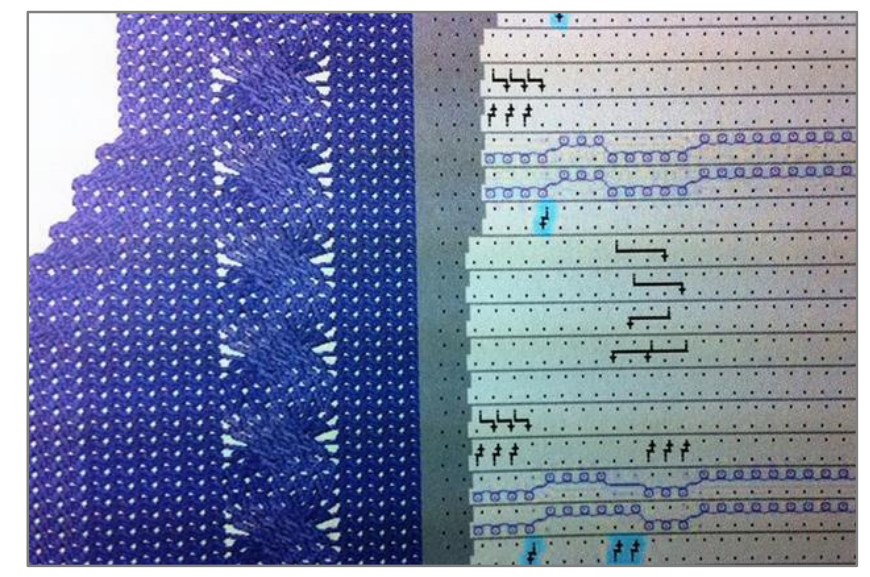

Figura 65 - Visualização de duas telas, real na primeira tela e técnica na segunda tela. Fonte: Stoll, 2012.

Essas evoluções tecnológicas demandaram da Stoll um acompanhamento próximo a seus clientes, os fabricantes do VMMR. Por essa razão, a empresa estabeleceu escritórios de informação de moda e desenvolvimento de produtos do VMMR em diversos lugares do mundo. No Brasil, a empresa estabeleceu escritórios em Caxias do Sul (RS) e no Polo do Sul de Minas Gerais.

Durante o estudo de caso, foram entrevistados o Diretor Geral, a Diretora de Desenvolvimento de Produto, a Gerente do Departamento Comercial do Polo do Sul de MG, dois Chefes de Programação e um Programador.

Neste sentido eles criaram um laboratório de desenvolvimento, denominado Prepara, sobre o qual o diretor da empresa realizou a seguinte análise:

"Montamos uma equipe de especialistas em desenvolvimento de produto, com duas modelista especializadas casando todo o processo com as estilistas e os programadores. Oferecemos esta equipe para que as empresas não precisassem parar as máquinas para fazer as pilotagens e pudessem cuidar da produção e da gestão do negócio. Trouxemos várias empresas tradicionais e mostramos o trabalho. Fomos muito elogiados, porém o retorno financeiro foi nulo. $\mathrm{O}$ cliente entende que, quando 
tem bom resultado com o processo de desenvolvimento na própria empresa, consegue criar uma vantagem competitiva e, obviamente, não tem interesse em divulgar esse trabalho, pois é resultado de esforço e investimento financeiro. Eles não dizem como funciona."

Segundo relato do programador entrevistado, muitos profissionais especializados em programação acabam substituindo a presença do estilista após algum tempo, por interesse do empresário em reduzir custos.

Outro profissional da área de programação relatou:

"Quando o estilista sabe o que quer e fica junto com o programador as coisas acontecem. Eu tecia um pano quadrado [no Fashion Week de 2011] e ele [estilista] ia espetando e moldando o tecido no manequim, e a peça saía. O manequim vestia, desfilava; ele ajustava e aprovava a peça. Depois, era a etapa de fazer a programação e tecer a peça.”

O mesmo programador relatou uma dificuldade comum observada no mercado:

"O cliente compra um desenho do estilista e passa para o programador. O desenho vem com pouquíssimas explicações de ponto. Por exemplo, "rendado" pode ter diversas formas. Na máquina existe uma infinidade de rendados no banco de memórias. (...) Não vejo inovação, a diferença é em pesquisa de tendências de moda, muitas vezes cópias já lançadas por grandes marcas".

Segundo a Diretora Comercial, os próprios estilistas e modelista locais não têm o preparo profissional adequado pois, o empresário é amador e não sabe exigir este conhecimento. Muitas vezes as empresas pequenas nem contam com os três níveis - estilistas, programadores e modelistas - e o processo é realizado entre o dono e o programador. Nas empresas maiores, normalmente são feitas pelo menos duas reuniões a cada coleção, uma na concepção e outra na aprovação: "Para empresas pequenas as etapas são encurtadas".

\subsubsection{Fabricante de Equipamentos Shima}

Com sede no Japão, a empresa foi fundada em 1962, com base no desenvolvimento do primeiro tear retilíneo automatizado para produção de luvas.

A Shima Seik é um dos maiores fabricantes de retilínea e desenvolve muitos tipos diferentes de máquinas. Algumas destas máquinas retilíneas minimizam os processos de corte e costura e outras os eliminam totalmente. 
A tecnologia Wholegarment ou Seamless - que quer dizer produzir malhas sem emenda de costuras - é um importante avanço no desenvolvimento de processos. Essa tecnologia foi desenvolvida em 1995 pelo Dr. Masahiro Shima, fabricante de máquinas retilíneas computadorizadas em sistemas de design gráfico.

O Dr. Shima teve esta ideia estudando as luvas sem emenda, e o objetivo era proporcionar um conforto maior ao usuário, evitando o incômodo de pontos mais grossos ou fios para amarração nas emendas.

Segundo o fabricante, as máquinas retilineas são divididas em três categorias com diferentes graus de sofisticação. São elas:

- Painéis retos ou tecidos retos a serem cortados com moldes pré-projetados e depois costurados e acabados;

- Fully fashioned - Partes da peça que saem das máquinas ja moldados a serem costurados e acabados;

- Wholegarment - São produzidas em uma peça inteira, tridimensionalmente, sem necessidade de corte e costura.

As peças produzidas no sistema Wholegarment têm os atributos essenciais do conforto como maciez, leveza e resistência com sofisticação. Ambos os processos de Wholergarment ou fully fashioned reduzem a quantidade de corte e costura para produção de peças prontas de VMMR.

A figura a seguir, apresenta um modelo vestindo uma peça pronta sem costura com tecnologia Wholegarment (2013). Os pontos sinalizados demonstram as possibilidades de movimentos das agulhas realizados pela tecnologia Wholegarment desenvolvido pela empresa Shima Seiki.

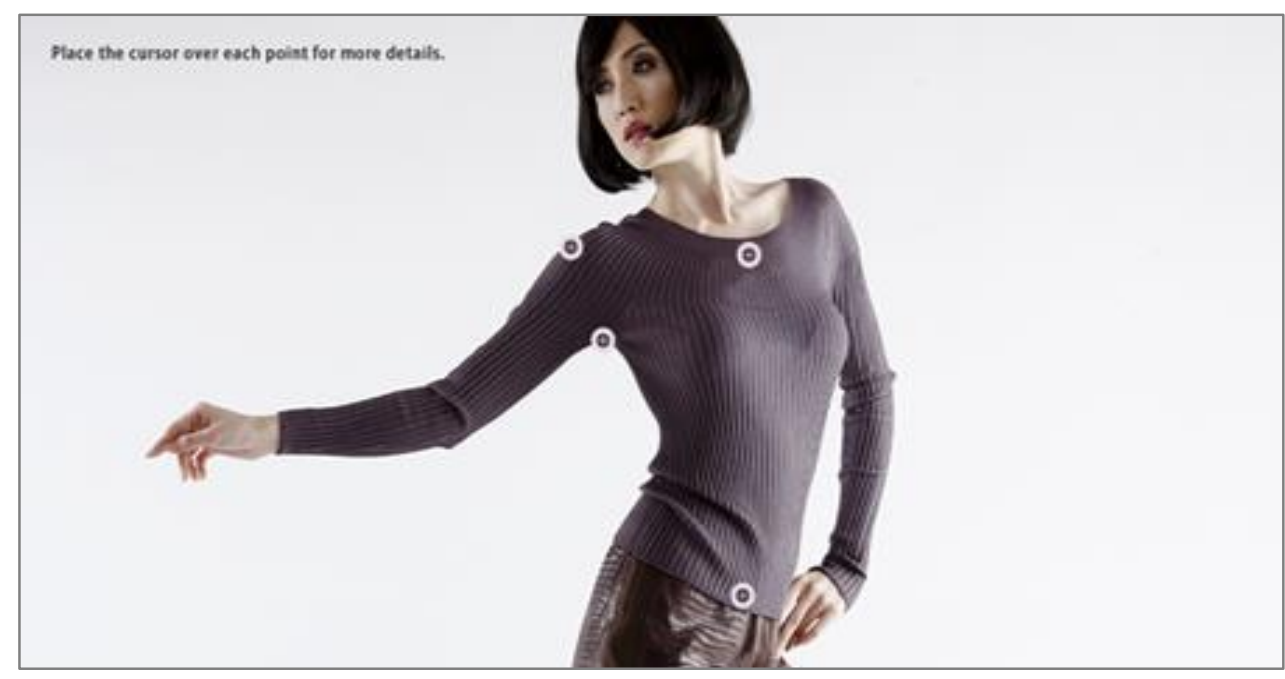

Figura 66 - Fonte: Shima Seiki, 2013. 
Conforme descrito pelo fabricante Shima (2010), quatro partes do corpo são beneficiadas na produção de VMMR no sistema Wholegarment:

- Ombros - modelagem tridimensional que são posicionadas para moldar a linha dos ombros e as partes de trás; o tecido de malha se molda da melhor forma nos ombros.

- Decote - decotado com formato das golas dispensando acabamentos sobrepostos; criam um refinado decote com linhas finas e sofisticadas.

- Cava da manga - sem a necessidade da costura entre as partes das peças, como mangas, elimina o desconforto do volume típico das costuras em baixo dos braços.

- Lados sem costuras nas laterais, não interferem na continuidade dos desenhos dos tecidos de malha de frente e das costas.

Este equipamento possui um monitor RGB, que cobre todas as gamas de cores e usa o sistema Adobe ${ }^{\circledR}$ para calibração. A tecnologia se completa com a utilização de estampadora. Esta máquina utiliza foto-espectrofotômetro para medição exata das cores. (Site SHIMA, 2013)

Durante a pesquisa do estudo de caso da Shima, foram entrevistados o gerente de programação do escritório de desenvolvimento de Monte Sião, e uma Estilista especializada no sistema desse fabricante.

Segundo os entrevistados, uma importante barreira para o aproveitamento dos sistemas em sua plenitude é o desconhecimento dos programadores e estilistas, que podem ou não alcançar um melhor resultado de desenvolvimento em novos produtos e demorar mais tempo durante o processo de desenvolvimento.

O escritório de desenvolvimento oferece alguns recursos, conforme declara a Estilista: “(...) temos um banco de dados que é renovado mensalmente. Essa informação vem do Japão, de acordo com as últimas pesquisas de tendência de moda, em forma de peças prontas e pontos que podem ser adquiridos no site".

Não se trata de uma questão apenas de desconhecimento do sistema de um ou de outro fabricante, segundo a opinião de um dos profissionais entrevistados "se a estilista não tiver um mínimo de conhecimento do fazer manual, não possui um conhecimento completo de malharia retilínea. (...) As modelistas e estilistas não chegam a assimilar muito bem a programação". 
Na percepção do Gerente de Programação, a modelagem é a parte mais desafiadora, pois, partindo do croqui, nem sempre o fio responde adequadamente à proposta, e a modelista tem que interagir com a equipe:

"No caso de produtos básicos a base de dados funciona muito bem, porém, para produtos inovativos a criação da peça tem que ser desenvolvida sobre o manequim. (...) Mesmo utilizando a simulação virtual, é fundamental sentir o tato e o caimento do tecido. (...) Nós chegamos a tecer cinco ou seis vezes o mesmo pano para aprovação".

Ainda segundo esse profissional, o sistema de tecer peça pronta não teve grande adesão no Brasil, por requerer matérias primas de melhor qualidade (lã animal e algodão), seguida de processos de lavanderia. Porém, boa parte da produção nacional é de acrílico e os fabricantes preferem não ter o trabalho da lavanderia. Dessa forma, a maior adesão é pelo processo de painel modelado, com sistema de fully fashioned (calado).

Segundo a estilista, no processo criativo são utilizados dois pontos importantes de decisão: um no início da coleção e outro no final. A reunião entre as disciplinas (estilo, programação e modelagem) acontece com o propósito de trocar informações sobre a ideia, questões operacionais e a viabilidade da peça. E o processo de criação inicia-se com uma pesquisa de tendência e análise de público-alvo, seguida da concepção de produto, estudo de tecnologia de fabricação e escolha de materiais, o que ocorre simultaneamente.

O Gerente de Programação da Shima Seiki colocou uma questão interessante sobre a liberdade do processo de criação do estilista, especialmente por seu perfil técnico, não é comum essa percepção: "Na minha opinião, se ele ficar preocupado com as dificuldades técnicas, não vai expressar sua criatividade adequadamente." Esse ponto de vista pode ser ponderado e questionado, mas certamente é um ponto discutido no mercado.

\subsubsection{Escritório comercial de importação de fios Pinotti.}

Foi entrevistado o Sócio-Diretor de um Escritório Comercial de fios importados diferenciados que atua no setor de malharia retilínea do Polo do Sul de Minas Gerais há mais de 20 anos. O convívio constante com empresários e profissionais da área trouxe ao entrevistado uma percepção singular a respeito da indústria e seus desafios.

Segundo o entrevistado, a maioria esmagadora dos programadores iniciou como tecelões que, por entender profundamente a formação dos pontos e o funcionamento das agulhas, evolui para a função de programação, mas sem capacitação formal. Por esse motivo, 
não costuma ter a habilidade de entender o processo criativo do estilista e a linguagem do modelista. Seu trabalho acaba sendo mais próximo do modelista, para definir o formato do molde e, quando isso não acontece, as peças podem ficar "muito quadradas, sem vestibilidade".

As empresas teriam percebido essa defasagem e, nos últimos anos, iniciaram o desenvolvimento de modelagens mais adequadas e com graduação de tamanhos:

“A modelista também precisa conhecer o processo de tricô na malharia retilínea e vai se comunicando com o programador na linguagem adequada. Por exemplo, quando a peça precisa de ajuste, ela mede a quantidade em centímetros e transforma o resultado para número de agulhas, de forma a se fazer entender pelo programador."

O entrevistado destacou também o importante papel do tecelão (operador de máquina), que interpreta o programa, tece a primeira peça, realiza a vaporização e compara com o molde. Caso haja problemas de tamanho, ele passa a informação ao programador para que possam ser realizados os ajustes: "se o programador não tiver noção de modelagem não é possível realizar o programa".

A opção da modelagem 3D ainda não teve adesão por muitas empresas, pois a máquina tem um alto custo e somente empresas de grande porte conseguem ter retorno sobre o investimento.

\subsubsection{LP estilo e modelagem}

A LP desenvolvimento estratégico de produto atua já oito anos na capacitação de empresas da região do sul de Minas Gerais, especialmente no que tange às atividades de estilo e moda.

Esta empresa se baseia na atividade profissional de sua sócia-diretora, cuja formação em Desenho Industrial se complementa com especializações em modelagem, desenvolvimento e planejamento de coleções em produtos de malharia retilínea e plano. Atuou como gerente de produto por mais de 30 anos em duas empresas da família. A primeira, 10 anos em produto de VMMR e por mais 15 anos com produto de moda em tecido plano.

Uma das atuações mais bem sucedida na consultoria foi através do desenvolvimento de produtos para outras marcas (sistema de Private Label), utilizando a produção em indústrias do polo do Sul de Minas Gerais. 
Neste caso, a consultoria desenvolve produtos de qualidade, trazendo seu conhecimento para gerar produtos interessantes às marcas, utilizando a base industrial do polo. Como subproduto, é perceptível o aumento da capacitação dos profissionais das fábricas.

De certa forma, esse processo segue ordem invertida, pois primeiro a consultora atende os clientes (marcas) em São Paulo com ideias de produtos ainda não desenvolvidos. Então, é feita uma concepção de produtos com a equipe de estilo das marcas. Estes produtos pré-concebidos são desenvolvidos nas fábricas do Sul de Minas Gerais, onde se selecionam fios, pontos, formas.

A consultora se envolve ativamente nos processos criativos, tanto com a marca quanto com a fábrica, muitas vezes desenvolvendo ela própria a modelagem e interagindo com os programadores das fábricas - interação que gerou grande capacitação para as empresas de malharia retilínea.

Cada profissional especialista contribui sobre a melhor forma de comunicar a ideia. A materialização desta ideia passa pelas mãos dos modelistas, programadores, gerentes de produto, piloteiras, entre outros profissionais, processo minunciosamente acompanhado pela consultora. O "fazer junto" resulta em produtos com maior qualidade e atende ao consumidor final. A consultora relata:

"No processo criativo o diálogo constante entre os profissionais aumentam as chances de uma coleção mais rica com detalhes interessantes. A consultoria oferece muitos materiais diferentes para acrescentar nos produtos, com fornecedores e preços previamente pesquisados e direcionados ao tema. No caso de produtos diferenciados com muitos trabalhos artesanais, esta comunicação é ainda mais complexa porque são envolvidos outros profissionais especializados externos a indústria como bordadeiras, fornecedores de materiais especiais, trabalhos com passamanarias, uso de materiais diferenciados de couro, peles, tecidos tecno e outros mais."

Segundo a consultora, o processo criativo caminha junto com o desenvolvimento de produto. A pesquisa é feita de acordo com cada marca e as escolhas são direcionadas a um ou mais temas dependendo do porte da coleção. Em seguida, são feitas propostas de modelos para a equipe de estilo das marcas, que selecionam ideias, transformam em desenhos com sugestões de padrões, materiais, tema e ambiência.

Neste trabalho são feitas viagens ao exterior para coleta de informação, estudo de modelagens e estilo detalhado, que baseiam a elaboração de books de tendência com temas 
direcionados à estação, considerando recursos disponíveis nos fabricantes do polo do Sul de Minas Gerais e direcionando as propostas ao público-alvo das marcas.

Uma das grandes dificuldades encontradas é a falta de informação de moda das pequenas empresas, que acabam, por isso, valorizando o trabalho do designer/estilista. Essas empresas se informam apenas nas palestras oferecidas por associações ou fornecedores de fios, o que empobrece o resultado final de coleções e reduz a diferenciação de produtos.

Porém, provavelmente a maior deficiência identificada é na capacitação em modelagem no desenvolvimento de produto de VMMR na região, o que afeta profundamente o produto gerado. Os problemas mais graves são:

- Tamanho único - a grande maioria das empresas produzia e ainda produzem artigos com tamanho único. O tamanho fica associado ao tamanho médio, porém, dependendo do fio e da máquina utilizada, este tamanho pode ser grande ou pequeno demais, variando ainda conforme a cor e pontos.

- As modelagens não tem padrão de medidas. As empresas não se preocupam com os detalhes de ombro, cavas, decotes e comprimentos.

- Praticamente não existiam modelistas especializados em malharia retilínea, o que limitava significativamente o potencial de geração de inovação pelas empresas, em especial nas de pequeno porte. As empresas maiores, mais estruturadas e com equipe técnica bem capacitada conseguiam inovar um pouco mais e obter melhores resultados no negócio, porém o conhecimento se mantinha isolado, disponível apenas internamente.

Apesar disso, muitas empresas conseguem bons resultados de vendas no inverno através de política de preços baixos, o que mostra que existe oportunidades de crescimento para empresas interessadas em se qualificar.

Durante esses oito anos trabalhados com empresas do polo, observou que muitas começaram a atuar na linha de produtos de malha circular. Neste caminho, a consultora introduziu técnicas de modelagem, acabamento e costura. Esta frente de produtos surgiu principalmente voltada para as estações mais quentes, com o propósito de substituir o tecido de malha retilínea em fio de acrílico que é inadequado para o verão e tentar manter um certo patamar de vendas. 
Outra ação comum nas empresas pequenas é abertura de lojas de varejo, o que acaba sendo muito favorável para o crescimento, pois traz para dentro do negócio a informação do mercado, através da figura de sua equipe comercial, muitas vezes forçando a melhoria de produtos e, consequentemente, a capacitação das equipes de desenvolvimento. 


\section{Análise e resultados}

No processo de desenvolvimento de produto o estudo do histórico da malharia retilínea, seus processos criativos e de alguns criadores, permitiu-se amplificar a percepção de versatilidade desse produto, já que expandem as possibilidades de aplicação de diferentes pontos, materiais, combinações de fios, tecnologias, entre tantos outros fatores.

Esta versatilidade permite ao estilista um grande universo de inovação, que pode ser utilizado pelas empresas como importante fator de diferenciação e apropriação de valor na cadeia de vestuário. Porém, o estudo de caso das dez empresas visitadas e entrevistadas, permitiu a observação de que ainda são poucas as empresas que utilizam os muitos recursos oferecidos pelas máquinas retilíneas de ultima geração.

\subsection{O processo de desenvolvimento de produtos}

O produto passa por várias etapas de análise de projeto. A concepção de produto do estilista acaba sendo o resultado do que ele consegue intuir da identidade da marca até chegar ao desejo de seu consumidor.

Os produtos de moda podem se destacar tanto por um aspecto visual e de uso inovador, como também manter um aspecto artesanal. A moda tem esse caráter momentâneo, dependendo das escolhas individuais. As pessoas fazem escolhas e se ornam pelo o que sentem e percebem do mundo, como elas podem querer aparecer, defender, se diferenciar das outras pessoas. Muitas vezes, simplesmente está a disposição da mídia e vestem o que aquele momento pede como correto, sem consciência da importância do seu visual no relacionamento com os outros, apenas cópia de uma referência do que é aceito na época.

A gramatura, as tramas e as possibilidades criativas da malharia são quase ilimitadas, e essenciais ao sucesso de uma coleção. Dependendo de certas características, estrutura da fibra dos fios, as finuras dos tecidos de malhas, os pontos escolhidos, a malharia pode ser trabalhada em diversos usos. Os tecidos finos podem ser modelados e drapejados como o tecido empregado para roupas de festa. Pela espessura dos fios, pela quantidade das fibras e 
disposição, pelos possíveis pontos e as técnicas que são escolhidas, muitos consideram a malharia retilínea a máxima expressão da fantasia e imaginação de um estilista.

A questão de permitir ao estilista o exercício da criatividade de forma plena ou de limitá-la de alguma forma com definições prévias (restrições de recursos, valores materiais, etc.) é relativamente controversa. Como produto que será comercializado, a empresa espera obter resultados e o estilista faz parte da cadeia deste processo. A experiência do trabalho do estilista no segmento específico, sua habilidade técnica e intuitiva e os resultados obtidos no decorrer das coleções vão positivando seu trabalho.

Por isso, podem-se avaliar métodos que permitam certo grau de inovação, mas não tirem de pauta a questão da aceitação comercial e viabilidade de custos. Uma possível forma é primeiro criar e depois selecionar. Ou seja, quanto mais claras forem as etapas e melhor se puder realizar cada uma delas, melhor será o resultado combinado de inovação e vendas principalmente, pois inovação na direção certa, gera grande valor agregado para o produto.

Essa talvez seja a mais forte razão para defender a integração sistêmica dos membros do departamento de criação (estilista, modelista, programador), com a condução de um gestor com visão externa, independente, para direcionar e ponderar os diversos fatores que influem na decisão final da coleção. O esquema a seguir, mostra a interação dos profissionais de desenvolvimento de produto de VMMR como solução para geração de qualidade e inovação.

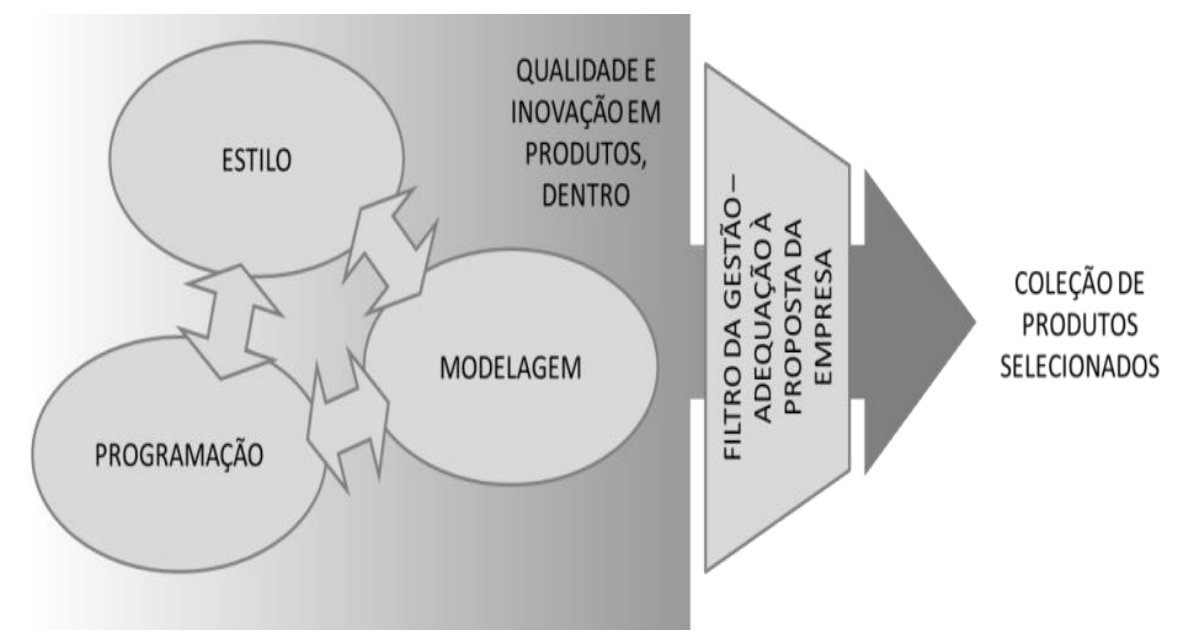

Figura 67 - Interação entre profissionais especialistas no processo criativo do VMMR. Fonte: Laura Piccinini, 2015. 


\subsection{Análise dos estudos de caso segundo o grau de estruturação e profissionalização do processo criativo e de desenvolvimento de produto}

A análise do processo criativo e de desenvolvimento de produtos permitiu a divisão desses estudos em três grupos de empresas, segundo seus graus de estruturação e profissionalização:

- GRUPO 01 - Processo criativo estruturado e profissionalizado, com certo grau de originalidade nos produtos gerados - EMPRESAS A e E.

- GRUPO 02 - Grau intermediário de profissionalização, pouco calcado em métodos e processos, baixo grau de originalidade dos produtos gerados, porém alta capacidade de realizar ideias de produto vindas de fontes externas com qualidade - EMPRESAS B, F e G.

- GRUPO 03 - Baixo grau de profissionalização e estruturação, muito baseado na força de trabalho de seus sócios, muitos dos quais programadores, e quase nenhuma originalidade nos produtos - EMPRESAS C, D, H, I e J.

Dentre todas as empresas, apenas a EMPRESA A e a EMPRESA E contam com um processo de desenvolvimento de produto original e estruturado. Original pois, não se baseia totalmente em cópias e, estruturado, pois segue de forma razoavelmente consistente um método de desenvolvimento de produtos. Além disso, observa-se que ambas as empresas se preocupam em contratar bons profissionais para a formação de seus departamentos, e não apenas de subcontratar mão-de-obra terceirizada para realização das atividades de estilo.

Associando a análise entre os estudos de casos das empresas com os depoimentos dos profissionais envolvidos com o mercado do Polo do Sul de Minas Gerais (fornecedores de máquinas Stoll e Shima e escritório comercial de fios), pode-se fazer as seguintes observações:

- Existe um alto envolvimento dos empresários nas atividades de criação, o que, de alguma forma, influencia qual a parte do desenvolvimento de produto a empresa dá mais ênfase. Como a parte mais essencial é a programação (essencial no sentido de que é impossível operar sem contar com essa área), as empresas mais simples são, em geral, operadas por programadores.

- A etapa de "Análise da Tecnologia" é relativamente pouco aprofundada nas empresas, que acabam por não ampliar as fronteiras dos conhecimentos, 
utilizam as mesmas bases de pontos já conhecidas. Segundo todos os especialistas técnicos entrevistados (Stoll, Shima e Escritório Comercial), existe uma vastidão de informações e conhecimentos disponíveis nos Escritórios de Desenvolvimento dessas empresas, mas não são aproveitadas de forma integral pelas empresas.

- De forma geral, as empresas não estão dispostas a despender grande investimento, contratando conhecimento externo de alta qualificação. Em vez disso, acabam comprando desenhos de estilistas locais de menor qualificação e de forma "avulsa", sem tanta interação com a equipe interna das empresas. Ou seja, a interação é nula, e, no final, é a interpretação que a equipe interna faz do desenho comprado é que se transforma no produto final.

- Diversos profissionais citaram que a reunião para troca de informação entre estilista, modelista e programador, acontece apenas no início e algumas vezes no fim da coleção, de forma que a comunicação entre os profissionais durante o processo é limitada a situações informais e não sistemáticas. Esse fator dificulta a validação dos resultados parciais durante o processo e pode representar alguns pontos de retrabalho.

- As empresas, em sua maioria, têm baixa propensão em inovar na escolha de materiais e em investir em processos de beneficiamento. As que o fazem, tendem a se diferenciar no mercado.

De certa forma, observa-se que diversos empresários dão pouca importância ao processo de criação original. Para atingir inovação, seria interessante haver, em primeiro lugar, uma concepção livre e, posteriormente, a busca pela viabilização dessa concepção através da interação entre os profissionais. No final, o produto teria que ser validado, comparando com a concepção original, para garantir que o processo criativo foi bem sucedido e gerou um bom resultado.

Quando isso não ocorre, é muito provável que a equipe técnica (modelista e programador) acabe trazendo a concepção criativa para materiais, formas e pontos com os quais têm mais familiaridade, reduzindo o grau de inovação. Esse ciclo é provavelmente comum nos casos em que é feita a compra de desenho de um estilista externo, sem definição de materiais e sem acompanhamento de prototipagem. 
O grau de inovação é exatamente o que difere as empresas do GRUPO 01 das empresas do GRUPO 02, que não são tão diferentes quanto à profissionalização da equipe interna. Neste ponto, vale a análise de que um dos grandes investimentos no processo de desenvolvimento de produtos, é o tamanho da equipe e sua estrutura. Sendo assim, cabe uma avaliação de que aprofundar a inovação no processo criativo pode representar um diferencial competitivo sem representar grande diferença de investimento para as empresas do GRUPO 02.

A respeito desse grupo, outra questão interessante é o processo de deterioração de duas empresas do GRUPO 02, que já contaram com estruturas maiores e não conseguiram resultados satisfatórios, tendo optado por fechar ou reduzir a empresa de forma significativa, depois de muitos anos de bons resultados. Por outro lado, a outra empresa do GRUPO 02 é, talvez, a mais bem sucedida em termos de negócio dentre todas as empresas estudadas.

Essa diferença radical de resultado financeiro entre empresas do mesmo "grupo" em termos de processo criativo demonstra o ponto, também esperado, que são muitos os fatores que interferem no resultado do negócio além do processo de criação. Por exemplo, provavelmente a competência mais forte na empresa B é a comercial que, associada a uma boa análise de mercado (produto, público, preço, entre outros fatores), permite a ela obter um ótimo resultado operacional. É visível que as empresárias da EMPRESA B destinam sua atenção muito mais a questões comerciais do que à própria criação e produção, uma vez que profissionalizaram essa função. É provável que esse fosse o fator de distinção do sucesso nesse grupo.

Esse foi um ponto também levantado pelo Diretor da Stoll, que considera que os empresários poderiam utilizar melhor a estrutura dos centros de desenvolvimento externos qualificados e direcionar seus esforços para a gestão do negócio em si.

Portanto, pode-se verificar que, na pequena amostra obtida com os estudos de caso, escolhida, de certa forma, intencionalmente pela pesquisadora para conhecer uma variabilidade relevante de métodos de criação no processo de VMMR no Polo, apenas 20\% das empresas tratam a criação de forma relativamente original. Provavelmente, não é coincidência o fato de ambas estarem hoje com bons posicionamentos de mercado e em processo de evolução.

Outra observação muito interessante e relevante dessa pequena amostra, é que uma parcela significativa das empresas conta com um de seus sócios acumulando a função de programação ou 
ainda, se já não conta, no passado (no início/formação da empresa) tinha um sócio nessa função. Não chega a ser uma conclusão surpreendente, dado que, com a automatização do processo de fabricação da malharia retilínea, a função de programação é obviamente indispensável e é uma competência central quanto maior for valor agregado do produto.

Segundo o entrevistado do Escritório Comercial de fios: "A indústria local determina: quanto menos trabalho, melhor. E, assim, não investe em produtos diferenciados”. Este depoimento ilustra a falta de investimento do empresário de pequeno porte no processo criativo. Por outro lado, as empresas mais estruturadas crescem porque investem na área de pesquisa, prototipagem, pilotagem, amostragem e busca por materiais diferenciados. Mas preferem ter o trabalho de forma interna.

Essa é uma estratégia arriscada do ponto de vista de inovação pois apenas o trabalho multidisciplinar integrado permite a criação de valor no produto, sendo difícil que o mesmo resultado seja obtido com a participação de apenas alguma linha de conhecimento.

Essa percepção de superficialidade no desenvolvimento do produto, fragilidade da capacitação de estilo e falta de comunicação eficiente entre os profissionais, torna o resultado pobre e de fácil superação por concorrentes, o que é um cenário comum nos estudos de casos de empresas pouco estruturadas do Polo do Sul de Minas Gerais.

Por outro lado, nas empresas mais estruturadas, o conhecimento técnico existe, mas não é disseminado dentro da empresa, sendo clara a necessidade de uma formação de estilo e modelagem de nível técnico na região.

Porém, após quase 20 anos da disponibilidade dessa tecnologia, poderia se esperar um amadurecimento do setor, com a profissionalização dessa função e a concentração do empresário em funções estratégicas, gerenciais e comerciais.

\subsection{Análise do processo de desenvolvimento de produto com base no esquema radial}

Utilizando o esquema radial baseado no modelo MAPP-3A para o processo de desenvolvimento de produto no VMMR, foi possível estudar com cada empresa a lógica do processo criativo, a sequência e distinção das atividades, a existência ou não de algumas etapas, conduzindo às seguintes observações: 
- A EMPRESA A foi a única dos GRUPOS 01 e 02 que declarou claramente realizar a análise tecnológica simultaneamente à criação do produto (croqui), porém observa-se que, mesmo nas empresas estruturadas, é difícil manter a completa liberdade do processo criativo, uma vez que boa parte dos profissionais que realizam as atividades de criação, está envolvida com outras atividades técnicas, como programação e/ou modelagem, e tendem a seguir os caminhos conhecidos.

- No GRUPO 01, as empresas colecionam dados de vendas de coleções anteriores e os utilizam para definição de mix de produto. Essa definição de mix é realizada logo após as pesquisas de tendências e antecede o desenho dos croquis.

- O GRUPO 03 não segue processos estruturados de criação e desenvolvimento de produtos. Em alguns casos, a atividade é tão rudimentar que não são usadas nem fichas técnicas formais e não alteram modelagem. Ou seja, dificilmente alguma das três funções principais (estilo, modelagem, programação) é explorada em sua plenitude.

- Apenas a EMPRESA E, utiliza o processo de prototipagem virtual, considera-o muito útil e econômico na sua estrutura e consegue tomar decisões com base na prova virtual, tanto sobre questões de estilo, quanto sobre questões de viabilidade econômica. Essas vantagens são especialmente importantes por se tratar de uma empresa especializada em produtos com tinturaria/lavanderia, processo que pode impactar em até $30 \%$ de encolhimento, e que, quando previsto, evitam grandes desperdícios na pilotagem.

- As empresas mais estruturadas e profissionalizadas tendem a realizar cada etapa com clareza, mesmo que alguma fase anterior tenha que ser revista ou ajustada posteriormente, preservando assim maior profundidade no processo criativo. Enquanto isso, as empresas menos estruturadas (GRUPO 03), realizam simultaneamente pesquisa de tendências, definição de produtos, pontos, materiais e etc., em um processo pouco estruturado que, eventualmente, pode pular etapas. Em muitos casos os processos são tão simples que são quase inexistentes. Por exemplo, a EMPRESA D sempre produz itens tão semelhantes que requer pouca programação, lembrando que 
essa é uma das competências mais essenciais das empresas fabricantes do VMMR.

- O que difere as empresas do GRUPO 01 das empresas do GRUPO 02 é muito mais a criatividade no processo criativo do que a profissionalização (estrutura de pessoal capacitado) e as etapas do processo.

Essas conclusões podem ser visualizadas na tabela a seguir, na qual as colunas representam as empresas estudadas, as linhas representam as etapas do processo adaptado do MAPP-3A, e as células centrais representam a sequência que cada empresa realiza as etapas do processo. Se a empresa não realiza determinada etapa, a célula foi marcada com um "X".

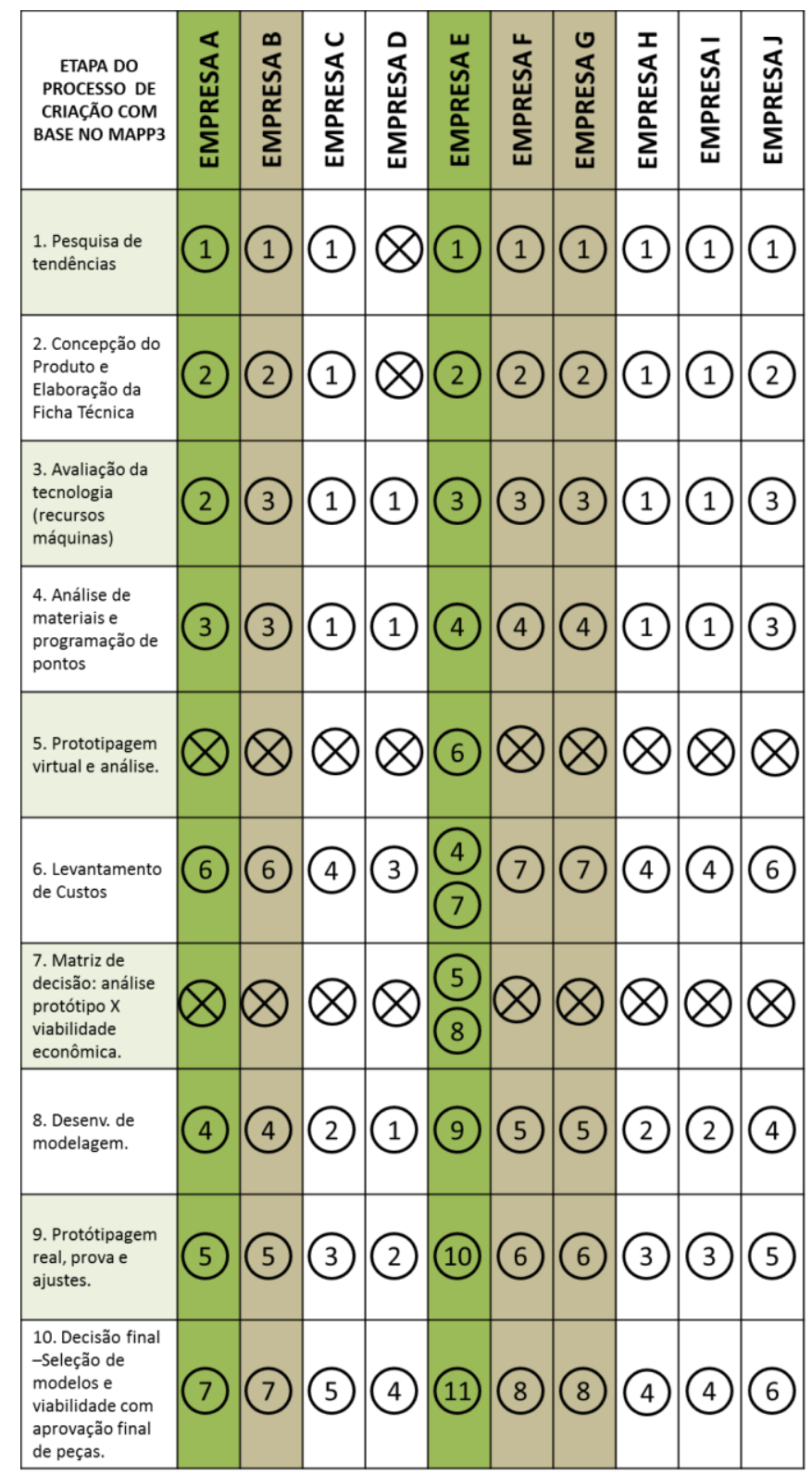

Figura 68 - Processo de Desenvolvimento de Produto adaptado do MAPP-3A. 
A partir do estudo dos casos, pode-se verificar que o formato mais usual de atividades no processo de criação do produto de VMMR nas empresas do Polo de Sul de Minas Gerais segue a sequência descrita no fluxo, conforme a figura a seguir.

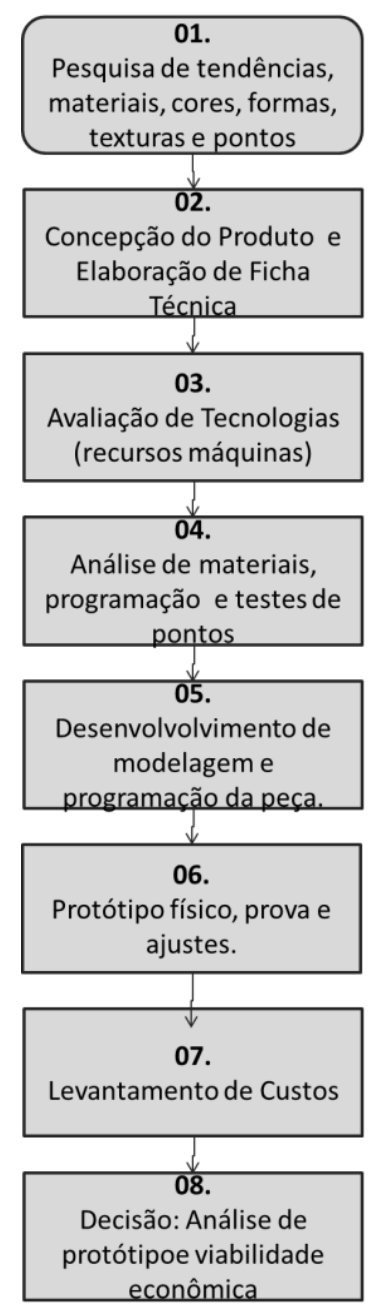

Tabela 2 - Desenvolvimento de produto. Fonte: Laura Piccinini.

Observou-se ainda, que nas empresas mais estruturadas existe uma distinção mais clara entre as etapas, e maior profundidade na execução das mesmas e, nas menos estruturadas, uma sobreposição de etapas, realizadas de forma mais simplificadas ou até mesmo não executadas. As etapas de 01 a 04 são as com sobreposição mais comum, que se feitas de forma desestruturadas e desordenadas, acabam reduzindo o grau de inovação do produto. Nesses casos, a etapa de modelagem e programação da peça é, em muitos casos, uma adaptação de produtos anteriores, ou seja, sem inovação mas, com modificações.

O protótipo virtual da peça pronta ainda é muito pouco utilizado pelo falso entendimento de que seu custo é alto, e também pelo desconhecimento de seus benefícios. 
Quando adotado, opera como uma primeira prototipagem física, oferecendo-se como uma alternativa mais rápida para eliminar os principais problemas de modelagem e padrão de tecidos e para análise de custos. Durante as entrevistas, surgiram também dois outros possíveis motivos da baixa utilização da prototipagem física: falta de conhecimento técnico dos profissionais ou falta de precisão da modelagem para produtos VMMR. Todavia, essas hipóteses e outras que poderão existir terão de ser verificadas em estudos futuros.

\subsection{O importante papel das soluções tecnológicas da indústria de equipamentos}

Os fabricantes de máquinas eletrônicas e periféricos possuem centros de desenvolvimento nos principais polos de produção, nos quais disponibilizam tecnologias e informações de moda atualizadas. Os programas (software) que passam pelo CAD (Computer Aided Design) têm interface simultânea com o design de peças de referência que vêm das duas principais empresas com matrizes localizadas na Alemanha (Stoll) e Japão (Shima).

Entende-se que é importante aumentar a participação dos clientes - fabricantes do VMMR - nestes centros de desenvolvimento de produto, de modo a amplificar suas competências de criação e desenvolvimento de produtos, bem como capacitá-los para utilizar ao máximo os recursos já disponíveis em seus equipamentos.

Os bancos de dados desses centros são baseados em informações históricas armazenadas, com uma infinidade de dados disponíveis aos clientes. Recurso que muitas vezes não é utilizado pelas malharias, que chegam a investir em máquinas de ultima geração para, posteriormente, não utilizar todos os recursos oferecidos.

A escolha da tecnologia de prototipagem e do material torna, possível a identificação antecipada de fenômenos físicos que podem ocorrer durante o processo de tecer o produto, como a retração, a deformação, correção, guia para o processo de finalização e reparos de possíveis erros. Porém, pode-se observar que apenas uma das dez empresas pesquisadas se beneficia desse recurso.

Essa tecnologia, denominada design 3D (solução Shima Design Solutions, com o software Apex3 e o M1 da empresa Stoll com o software SIRIX) envolve sistemas de desenho virtual com todas as ferramentas necessárias para criação no mercado de moda em sistema 
facilitado de manuseio e interação (Windows). A modelagem 3D permite que o design da modelagem com os contornos de aumento e diminuição da silhueta da roupa possa ser reproduzido exatamente como idealizado.

Compreendendo a barreira intrínseca de adesão das empresas às novas tecnologias, os fabricantes de equipamentos trabalham para tornar interface entre homem e máquina cada vez mais simples, com avanços tecnológicos de tradução de linguagem que propiciam uma interação rápida e precisa. Nas partes mais complexas, os estilistas tem dificuldade de entender o processo de construção da peça na programação. Na simulação de determinadas estruturas, esta parte fica facilitada porque, o próprio sistema tem um banco de dados bem vasto que pode ser visualizado. Não é necessário entender de programação para entender a programação virtual. Com o croqui, a tabela de medidas da empresa, na maioria das vezes o programa fornece a peça pronta. Na realidade, a modelagem vai se dificultando dependendo da complexidade do modelo e das especificidades da matéria prima.

Uma tecnologia muito pouco utilizada no Brasil, oferecida por máquinas dos dois fornecedores estudados, Stoll e Shima Seiki, é a construção sem costuras, Wholergarment que oferece benefícios substanciais para o VMMR, tais como:

- Os padrões e desenhos que permanecem contínuos, sem as costuras e emendas ao longo de toda a peça, são: de frente para trás, em cima dos ombros, e nas costuras das mangas; as malhas são reversíveis e podem ser produzidas sem o peso adicional e volume de malhas duplas com acréscimo de costuras e arremates que fazem volumes como as costuras de interloque.

- Os gargalos na cadeia de abastecimento causados por trabalho intensivo de processos de corte e costura são minimizados ou eliminados.

- A quantidade de material de tecido de malha que é descartada depois do corte de cada parte do molde é minimizada ou eliminada, contribuindo para a redução de resíduos que poluem o meio ambiente.

- Permite a produção de uma peça de cada vez, de forma que o número requerido de peças de vestuário pode ser tricotado no tempo exigido, permitindo verdadeira produção de acordo com a demanda.

- Benefícios para o consumidor, de conforto superior por acabar com costuras indesejáveis, o que é especialmente eficaz no caso de roupa infantil e com 
características hipoalergénicas, onde costuras pode ser uma fonte de irritação da pele.

- Reduz a interferência na elasticidade natural da malha, permitindo trecho superior e mobilidade (saias e vestidos sem costura tem um caimento mais fluído e leve sem armar).

- A construção de uma peça permite que o estresse da malha se distribua uniformemente por toda parte, evitando pontos de pressão localizados, que podem causar desconforto. Essa tecnologia de peça pronta é mais utilizada em países com um consumidor mais exigente que exige fios de maior qualidade com fibras naturais de algodão e de origem animal como lã de cachemira e mohair. Esses fios nobres tem um alto custo, portanto a tecnologia é muito adequada, pois tem uma grande economia de matéria prima e com um descarte quase zero. 


\section{Conclusões}

A pesquisa sobre o desenvolvimento de produto de VMMR enfatizou a produção de conhecimento que possa contribuir para as indústrias do setor no Brasil e, em especial, ao Polo Industrial do Sul de Minas Gerais.

Trata-se de uma abordagem que visa aperfeiçoar possibilidades na fase da criação, no desenvolvimento da peça piloto e dos processos produtivos, gerando a partir do levantamento de referencial teórico e do estudo de casos, o melhor entendimento de um segmento pouco estudado e analisado, com escassez de bibliografia.

Neste trabalho foi possível constatar, através das pesquisas realizadas em campo, que a indústria nacional vem sofrendo uma ameaça real ao longo dos anos, agravada na última crise de 2011, quando muitas malharias foram desativadas. A sua causa é a invasão no mercado nacional, dos produtos chineses, através da importação, o que tem sido devastador para os produtores locais. Dois exemplos reais da efetividade dessa ameaça são as empresas F e G, que praticamente encerraram as atividades, e sobrevivem agora, com uma realidade de quase subsistência.

Essa concorrência se deu, tanto porque os produtos chineses são oferecidos a preços mais baixos do que os nacionais, mas também porque se adequam ao estilo que o consumidor deseja de forma muito mais ágil do que a indústria nacional é capaz de reproduzir. A questão do custo não foi o foco dessa pesquisa, uma vez que envolve inúmeras variáveis não apenas peculiares ao setor, com questões cambiais e de produtividade, mas muitas vezes foi citada durante os estudos de casos.

Muitos fabricantes de VMMR chegaram a realizar importações da China, o que resultou na desvalorização da produção local em termos de qualidade/preço, expondo seus concorrentes e depois a si próprios, à concorrência dos importados. Essa estratégia conduziu uma grande redução de postos de trabalho e fechamento de muitas empresas.

As prefeituras locais dos polos pesquisados, têm feito um esforço no sentido de oferecer cursos gratuitos para formação e qualificação de pessoas, o que em longo prazo espera-se um resultado de desenvolvimento sustentável na região. Porém, essa realidade ainda é distante e sente-se uma fragilidade premente no setor. 
A questão da adequação de produto está no cerne desta pesquisa, já que oferecer o produto do estilo desejado do consumidor, no tempo certo em relação à geração de demanda da moda global, é fundamental, e depende diretamente dessa tecnologia interativa entre estilo, modelagem e programação na VMMR.

Ao entrar no ciclo vicioso de maus resultados, muitas fábricas procuraram novas estratégias para sobrevivência, como, por exemplo: fabricação de produtos de malha plana circular e tecidos planos; abertura de novas frentes de ponto de venda em outras cidades; terceirização de toda a produção em pequenos fabricantes (mantendo a marca e as lojas). Essas medidas, isoladamente ou mesmo em conjunto, nem sempre se reverteram em sucesso financeiro.

A grande maioria das empresas investe poucos recursos no desenvolvimento de produto e utilizam os escritórios e estilistas locais limitados em informação de tecnologia e moda. Os produtos desenvolvidos tem pouca inovação. Os produtos são direcionados para o consumo local ou encomendas de empresas estruturadas que enviam desenhos já elaborados para complementar suas coleções.

Neste ponto, observa-se uma problemática nas últimas pesquisas em indústrias do VMMR. Muitas vezes as indústrias investem em equipamentos de última geração, mas não têm técnicos e estilistas que acompanham estas evoluções. Os centros de desenvolvimento de produto das indústrias de máquinas têm muitos recursos e informações disponíveis sem custo, porém as maiorias das empresas não conhecem ou não utilizam estes treinamentos. A maioria dos programadores e estilistas das empresas de pequeno porte são free lancers e gerenciados de um modo particular e amador pelos proprietários. Às vezes demoram muito tempo para programar novos produtos por desconhecer os recursos que o programa de software oferece.

O vestuário de moda e, principalmente, na malharia retilínea tem em si uma liberdade criativa nas suas várias etapas do processo de fazer. Os desenvolvimentos em VMMR são baseados no histórico com uma enorme quantidade de dados. O processo de engenharia é sistemático e mecânico que se contrapõe ao processo da moda que é criativo, imaginário e espontâneo. O investimento em pesquisas com possibilidades criativas de novos designs resultam em produtos que, muitas vezes, são mesclados com partes artesanais e partes com tecnologias avançadas proporcionando uma individualização tão valorizada atualmente no mercado do vestuário de moda. 
Algumas empresas com maior porte investem em programas de simulação virtual em máquinas eletrônicas que apesar do investimento ser elevado, podem gerar uma maior qualidade e rapidez no desenvolvimento de produto. Quando se faz a simulação da peça no manequim virtual, temos também a percepção de como os diferentes tecidos caem e se distorcem no corpo. No programa de simulação virtual para estilo, percebe-se a sensação de conforto, ele mostra aonde o tecido tem mais tensão no vestir da peça com ilustração por cores. Os novos estilistas terminam a faculdade e rapidamente entendem o sistema de programação virtual de estilo que está disponível em linguagens conhecidas com comandos similares a photoshop e CorelDraw. Essa é uma nova tendência, além de vender máquinas, os fabricantes de máquinas retilíneas também oferecem programas para facilitação do uso de equipamentos para desenvolvimento de produto.

As malharias podem escolher trabalhar com foco na produção de produtos independente do departamento de criação de novos produtos e contratar escritórios especialistas para este fim. Os escritórios de desenvolvimento de produto especializados no setor de criação em produto de VMMR existem há muito tempo em países mais evoluídos neste campo, resultando em produtos com maior qualidade em estilo e modelagem dentro das tendências internacionais.

Outro fator relevante é que o desenvolvimento de produto de VMMR ainda depende muito dos lançamentos das tendências internacionais, principalmente em suas matérias primas, as fibras que constituem os fios e a coloração. As empresas estão investindo em lançamentos de fios com fibras biodegradáveis, e com corantes menos agressivos a natureza. $\mathrm{Na}$ fabricação do produto a pesquisa mostrou algumas formas de ações em direção a sustentabilidade do planeta como o reaproveitamento das sobras de fios e tecidos para confecção de novos produtos e coleta seletiva de lixo na cidade.

De forma geral, observa-se no setor um grande espaço para aprofundamento de conhecimentos técnicos e de recursos para a evolução do processo criativo, através da adoção de métodos de desenvolvimento de produto que garantam espaço de inovação nas coleções, o que promoveria ganhos de competitividade através da diferenciação e aumento de valor agregado. Além disso, também existe espaço para a melhoria do processo de criação, tanto por parte da diferenciação na etapa da concepção do produto, quanto por parte da busca de soluções técnicas (modelagem e programação de pontos e uso de recursos de máquina). A equipe de desenvolvimento de produto aplicando os recursos de metodologia em etapas 
estudados neste trabalho terá uma interação com mais trocas de informações e um resultado muito mais criativo.

Para atingir esse resultado da mesma forma, também seria necessário melhorar a formação de modelistas e programadores para que conheçam as mesmas bases de informações técnicas e entendam a linguagem de estilo com mais facilidade. Um possível caminho para atingir tal resultado, seria a profissionalização do setor com a formação de estilistas mais qualificados, especialistas no setor, apoiados por processos sistematizados de avaliações de produtos durante a prototipagem que preservem o estilo originalmente concebido e gerem inovações. O estilista, ao ampliar o seu universo de conhecimento de pontos e recursos de máquina também recebe informação valiosa para a criação, evitando a repetição de produtos ano após ano.

\subsection{Conclusões Finais}

A pesquisa enfatizou estudos nas seguintes hipóteses:

- O processo de desenvolvimento de produto do VMMR é dificultado pela falta de conhecimento e comunicação dos profissionais que atuam no desenvolvimento de produto da indústria de VMMR.

- Melhores conhecimentos em estilo, modelagem e programação de máquinas poderão melhorar o desenvolvimento de produto e consequentemente gerar inovação no produto de VMMR.

Este estudo conclui que investir em conhecimento e, mais comunicação entre os profissionais que atuam no desenvolvimento de produto na malharia retilínea, são as alternativas mais importantes para a inovação e qualidade nos produtos de Moda. Os polos de indústrias em Malharia Retilínea no Brasil tem uma estrutura implantada com um grande valor produtivo e criativo. Fazem-se necessárias ações de capacitação de profissionais que contribuam para seu desenvolvimento. Destaca-se a seguir algumas conclusões:

- Adoção de Métodos que garantam inovação e diferenciação resultando em maior valor agregado ao produto de VMMR.

- A indústria nacional de VMMR tem ameaça real de empresas de importação de produtos asiáticos. Necessidade de maior adequação de estilo e custos ao consumidor brasileiro - tecnologia interativa de estilo-modelagem - tecnologia. 
- Alto investimento em aquisição em máquinas e equipamentos de última geração e pouco investimento em informação e treinamento de pesquisas em estilo e modelagem de informação de moda dos principais centros de pesquisas.

- Pouco investimento em treinamento de estilistas e técnicos específicos da área de malharia retilínea nos programas de última geração de simulação virtual importante para geração de maior rapidez em qualidade e inovação.

- Os polos de indústrias em Malharia Retilínea no Brasil tem uma estrutura implantada com um grande valor produtivo e criativo. Faz-se necessário a criação de centros de capacitação dos profissionais das áreas de criação e produção em VMMR que contribuam para a geração de produtos com valor adequados a necessidade dos consumidores no Brasil como também produtos para exportação.

- Necessidade de centros de treinamento de criação de novos produtos independentes das indústrias de produção. Existe uma defasagem de informação com os centros de desenvolvimento de produtos de moda nacional com os principais centros internacionais.

Por esses motivos, entende-se que é importante criar e ampliar centros de treinamentos e de desenvolvimento de produto de VMMR nos principais polos de fabricação, contemplados por esse estudo, área do vestuário que pode ser mais bem explorada, sendo considerada uma oportunidade para os estilistas no Brasil.

É muito provável, todavia, que, se fosse possível realizar uma pesquisa mais ampla, com mais empresas, em formato de "survay", na escolha intencional de encontrar os processos criativos com foco em geração de inovação dentro de desenvolvimento de produtos os resultados seriam mais precisos e detalhados.

A indústria de vestuário em malharia retilínea tem muitos campos a serem estudados. Algumas pesquisas sugeridas são de fios com propriedades de conforto, construção de tecidos com camadas de tecidos diferentes e com modelagens diferenciadas para uso em uma infinidade de produtos, produtos com modelagem prontas de máquina com descarte zero.

Nesta dissertação, espero ter contribuído para o desenvolvimento de produtos no campo do VMMR e, oferecer com este estudo, uma base de conhecimento para futuras pesquisas. 


\section{Referências}

ACSELRAD. H. Discursos da sustentabilidade urbana. Rio de Janeiro, 2013.

ALFIERE, P. Fios Fiados Mistos E Seus Efeitos Nas Malhas - Fibras Desenvolvimento de Produtos. TBM, Palestra. São Paulo. 2011.

ALMEIDA, Marco Antônio Chaves. C. Projeto de Pesquisa: guia prático para monografia. $5^{\text {a }}$ ed. Rio de Janeiro. Wak Editora. 2012.

ARAUJO, M.; Castro, E.M. Manual da Engenharia Têxtil. Lisboa: Fundaçào Calouste Gulbenkian, 1984, V.1.

BOFF, L. História da sustentabilidade. São Paulo, 2007.

BAUMAN, Z. Modernidade Líquida. Rio de Janeiro. Zahar, 2003.

BAUMAN, Z. Vida Líquida. Rio de Janeiro. Zahar, 2007.

BACK, N; OGLIARI, A; DIAS, A; SILVA, J.C. PRODIP -Projeto Integrado de Produto. Planejamento, Concepção e Modelagem. Tese de Mestrado. São Paulo. USP, 2008.

BAUDOT, F. Moda do Século. São Paulo. Cosac \& Naify Edições, 2001.

BERLIM, L. Moda e sustentabilidade: uma reflexão necessária. São Paulo. Estação das Letras e Cores, São Paulo, 2012.

BLACK, S. Knitwear in Fashion. New York, USA: by Thames \& Hudson Inc., 2002.

BRAGA, J. História da moda: uma narrativa. 4ª ed. São Paulo. Anhembi Morumbi, 2006.

BREHM, L.M.S. Curso de Modelagem Básica Para Malharia Retilínea. Caxias do Sul. Rio Grande do Sul, 1997.

BREHIM, L. S. RUTHACHILLING, E. A. A interface entre as ferramentas tecnológicas promovidas pelo designer na construção de tecido em malha de retilínea. Artigo, colóquio da moda, Caxias do Sul, Rio Grande do Sul, 2010.

CALDAS W. Uma utopia do Gosto. São Paulo. Brasiliense, 1999.

CARVALHINHA, M.P. O Setor do Vestuário: Uma análise sobre as possibilidades estratégicas das empresas do vestuário no Brasil. Dissertação apresentada na Escola Politécnica da Universidade de São Paulo, São Paulo. 2007.

CASTIGLIONI, M. Tecnologia Tessile III: maglieria e confezione, Corso de la magliera nella filiera tessile. Universitá degli Studi di Bergamo, Facoltá di Ingegneria, BE. Italia, 2010 . 
CASTILHO, K. Moda e linguagem. São Paulo. Anhembi Morumbi, 2009.

CETESB E SINDITÊXTIL. Guia Técnico Ambiental da Indústria têxtil. São Paulo, 2009.

CONTI, M. C. In: Textile vivant, Experiences and researches In: textile design, La Triennalle, Milano, 2014.

DYKES, R.; ENTICKNAP S. Learn Modern Stripes. Machine Knit With Knit-1. London. Ltd, 2008.

DYKES, R.: ENTICKNAP S. Learn Industrial. Machine Knit, With Knit-1. London. Ltd., 2012.

DYKES, R.; ENTICKNAP S. Learn Inventive Intarsia. Disponível em: <www.knitdesigncourser.com>. 2013.

FLETCHER, K.; GROSE, L. Moda e sustentabilidade: design para mudança. São Paulo. Editora Senac, 2011.

FOGG, M. Vintage Fashion Knitwear/Collecting and wearing designer classics. Carlton Books, London, 2010.

FRISA, M. L.: MATTIROLO, A., TONCHI, S. Bellissima: L'Italia Dell'Alta Moda, 19451968. Milão, Electra, Roma, MAXXI, 2014.

GRAVE, M. F. A modelagem sob a ótica da ergonomia. Zennex, São Paulo, 2004.

JONES, J. J. Professione stilista. Terza edizione, Logos, Modena, 2011.

LAYRARGUES, P.P. Do Eco desenvolvimento Sustentável. 1997.

LAVER, James. A roupa e a moda: Uma história concisa. São Paulo. Schwarcz, 1989.

MARIANO, M. L. V. Da construção a Desconstrução. Mestrado, Anhembi Morumbi, São Paulo, 2011.

MATKOVIC. Y .M. P. The Power of Fashion: The influence of Kinitting Design on the Development of Knitting Tecnology. Croacia: University of Zagreb, 2010.

MEDEIROS, M. K. Tecnologia têxtil. Apostila, São Paulo, 1999.

MELLO, W. B. MAPP-3A Proposta de um método aberto de projeto de produto, Três alternativas de Criação. Dissertação de Mestrado, Orient. Profa. Dra. Brenda C. C. Leite; USP, Civil, São Paulo, 2011.

MENDES, D.M. Sacomano, J.B., Fusco, J.P.A. Rede de Empresas, A cadeia têxtil e as estratégias de manufatura na indústria brasileira do vestuário de Moda. São Paulo. Arte e Ciência, 2010. 
MONTI, G. Atraverso uno Specchio di carta. In: Bellissima: L'Italia Dell'Alta Moda, 19451968. Milão, Electra, Roma, MAXXI, 2014.

MISSONI. Calendoscopio Missoni, Catalogo da Mostra do Museo Provinciale de Gorizia, Italia, 2006

MUNARI, B. Das Coisas Nascem Coisas. São Paulo. Martins Fontes, 1998.

NEVES, B.N. Estudo de Projeto têxtil em um contexto de design de interação. Dissertação de Mestrado, Mestrado com ênfase em tecnologia e Design, UFRGS. Porto Alegre, 2010.

OSTROWER, F. Criatividade e Processos de Criação. 9a edição, Petrópolis. Ed.Vozes, 1993.

PAHL, G.; BEITZ, W. Engineering Design: A Systematic Approach. Berlim, 1996.

POLETTI, F. Maglifico: 50 anni di straordinaria maglieria made in Italy. Catalog pubblicato in occasione della Mostra: Maglifico. Italian sublime knitscape. Milano, Skira, 2012.

PUGH, S; MORLEY, I. E. The Organization of Strathclyde, in Creating Innovative product Using Total Design. Cap. 29. D. Clausing \& R.S. Andrade (Orgs). Editora Addison Wesley, 1988.

RECH, S. R. Qualidade na criação e desenvolvimento do produto de moda nas malharias retilíneas. Dissertação de Mestrado, Engenharia de produção. Florianópolis. UFSC, 2002.

RECH, S. R. Um Modelo Conceitual de Analise da Competividade no Elo da Confecção. Dissertação de Doutorado, Engenharia de Produção. Florianópolis. UFSC, 2006.

RECH, S. R. Moda: por um fio de qualidade. Florianópolis. UDESC, 2002.

RINALDI, R. M.; PEREIRA L. M.; LOVISON, D. M.; MENEZES, M. S. Doutorando; Tecnologia aplicada aos fios têxteis: Moda e Consumo. $9^{\circ}$ Congresso Brasileiro em Pesquisa e desenvolvimento em Design; Bauru. UNESP, 2010.

ROOS, D. B. O setor industrial de malharia de Caxias do Sul. Um estudo de aglomerado de pequenas empresas. Faculdade de ciências Econômicas da Universidade do Rio Grande de Sul, Mestrado Porto Alegre, 2001.

SANCHES, R. A.; BARUQUE-RAMOS, J. DEDINI, F. G.; BOUERI FILHO, J.J MANTOVANI, W. Proposta de metodologia para seleção de matérias-primas utilizadas em artigos para vestuário. $5^{\circ}$ Congresso Internacional de Pesquisa em Design. Bauru, 2009.

SANCHES, R. A. Otimização dos Parâmetros de Regulagem das Máquinas Circulares de Malharia, utilizando a metodologia Taguchi. São Paulo, 2001. 
SEBRAE. Análise de Atratividade dos APLs de Monte Sião. Monte Sião. 2012.

SEVEGNANI, F. A estratégia de manufatura retilínea pela análise do processo produtivo. Artigo, IV, CNEG. Rio de Janeiro, Brasil. UNIP, 2008.

SISSONS, S. Malharia, Fundamentos de design de moda, Porto Alegre, Bookman, 2012.

SPENCER, D. J. Knitting Technology: A comprehensive handbook and practical guide. Third edition. Oxford, UK. Woodhead Publishing Limited, 2001.

STOLL, H. P. The History Book, 135 Years, Stool. The Right Way to Knit, ITMA, SHANGAI, 2008.

TEXTILE VIVANT. Experiences and researches in textile design. La Triennalle, Giovanni Maria Conti, Barbara del Curto, Maria Grazia Soldati. MILANO, 2014.

TICINI, L. C. Missoni e la seduzione del processo criativo. In: MISSONI, Calendoscopio Missoni, Catalogo da Mostra do Museo Provinciale de Gorizia, Italia, 2006.

TRAINI, C. Macchine e Moda: il percorso tecnologico nella maglieria. In Maglificio; 50 anni di straordinaria maglieria made in Italy. Catalogo pubblicato in occasione della Mostra: Maglifico! Italian sublime knitscape. Milano, Skira, 2012.

TREPTOW, D. Inventando moda: planejamento de coleção. $2^{\mathrm{a}}$ ed. Brusque. D. Treptow, 2003.

TURNEY, J. The Culture of Knitting, Berg. New York, USA, 2009.

VACCARI A. La cultura dell'alta moda italiana: Appunti per una definicione. In: Bellissima: L'Italia Dell'Alta Moda, 1945-1968. Milão, Electra, Roma, MAXXI, 2014.

Wold Fashion. Ed. 143, 2013, p.15.

SHIMA SEIKI. Disponível em: <www.shimaseiki.com>. Acesso em 25/05/2015.

KNITTING INDUSTRY. Disponível em: <www.knittingindustry.com>. Acesso em 25/05/2015. 


\title{
10 Glossário
}

\begin{abstract}
Alta Moda - Termo que se refere à Moda Italiana artesanal provinda de peças únicas, vestuário elegante, de luxo, reservados a uma clientela de elite.

Atelier - O atelier de moda é normalmente um espaço composto de salas com suportes de confecção de vestuário que materializam as ideias dos estilistas.

Botoné - Tecido fantasia com efeito de coco ralado, produzido com fios fantasia do mesmo nome e que têm pequenas bolotas de fibras enroladas.

Chiffon - origina-se na palavra francesa que significa trapo. Tecido muito fino e transparente de seda ou de fibras químicas (poliéster ou poliamida), com fios. A palavra chiffon utilizada com o nome de outros tecidos denota leveza: crepe chiffon, tafetá chiffon, veludo chiffon.
\end{abstract}

Crochet - Trabalho de linha que se faz com agulha especial com um dente na extremidade. Este dente quando entrelaçado com o fio resulta em um nó. O entrelaçamento de um nó com outro resulta em uma carreira de nós que trabalhado com laçadas diferentes, compõem desenhos e tecidos diferentes. Alguns tecidos de crochê podem ser confundidos com tecidos de malha retilínea, pois seus rendados e volumes são parecidos com os tecidos que são produzidos nas novas tecnologias das máquinas retilíneas.

Commodity - é um termo da língua inglesa (plural commodities), que significa mercadoria. Utilizado nas transações comerciais de produtos de origem primária na bolsa de valores. O termo é usado como referência aos produtos de base em estado bruto (matériasprimas) ou com pequeno grau de industrialização, de qualidade quase uniforme, produzidos em grandes quantidades e por diferentes produtores.

Finura - Finura é a quantidade de agulhas existentes em uma unidade de medida. No Brasil, utiliza-se o sistema inglês, ou seja, o número de agulhas por polegada $(25,4 \mathrm{~mm}) \mathrm{do}$ perímetro do cilindro. Exemplo: finura 5 (5 agulhas em 1 polegada).

Figurinista - Profissional que representa graficamente o modelo ou uma peça para definir suas linhas com descrição de detalhes.

Fully fashioned - ou fullyfashioned quer dizer uma malha que já é tecida no tamanho e formato desejado do molde na própria máquina não necessitando assim de recortes. Esse 
tipo de trabalho é mais visível nas mangas, cavas e golas onde se percebem os "diminuídos" feitos na própria malha que possibilitarão assim um acabamento diferenciado.

Jacquard - Jacquard é o nome dado a padronagens complexas de entrelaçamento, tanto em tecelagem como em malharia em Jérsei duplo (no caso de Jérsei simples chama-se entarcia).

Jérsei - Tecido de malha leve e de ligamento simples, muito usado para lingerie. $\mathrm{O}$ tecido de Jérsei possui uma única face, é característica deste tecido repousar ao entrelaçamento de pontos na mesma direção, no lado direito, ao passo que no avesso notamos as laçadas produzidas de forma semicircular.

Patchwork - A tradução literal de patchwork é "trabalho com retalhos". É uma técnica que une tecidos com uma infinidade de formatos variados.

Plush - (plâch) sm (ingl) Espécie de veludo de algodão, elástico.

Private Label - Expressão em inglês que significa etiqueta privada. As empresas que produzem mercadorias para marcas de terceiros, atendendo todas as exigências e especificações de cada cliente.

Título do fio - O título de produtos têxteis é apresentado por um número que expressa uma relação entre um determinado comprimento e peso correspondente. E a densidade linear do produto.

Wholergarment - Expressão em inglês que significa peça inteira pronta. Termo utilizado na malharia retilínea que significa um produto de peça pronto inteiro que é tecido na máquina sem necessidade de costuras para emendar as partes. A blusa é tecida inteira com frente, costa e mangas sem costura pronta e acabada. 


\section{ANEXO}

\section{Entrevistas com Profissionais que trabalham em VMMR, ano de 2014.}

Foram feitas entrevistas em desenvolvimento de produto de VMMR em forma de perguntas em aberto com base em modelo de esquema radial de etapas em desenvolvimento de produto.

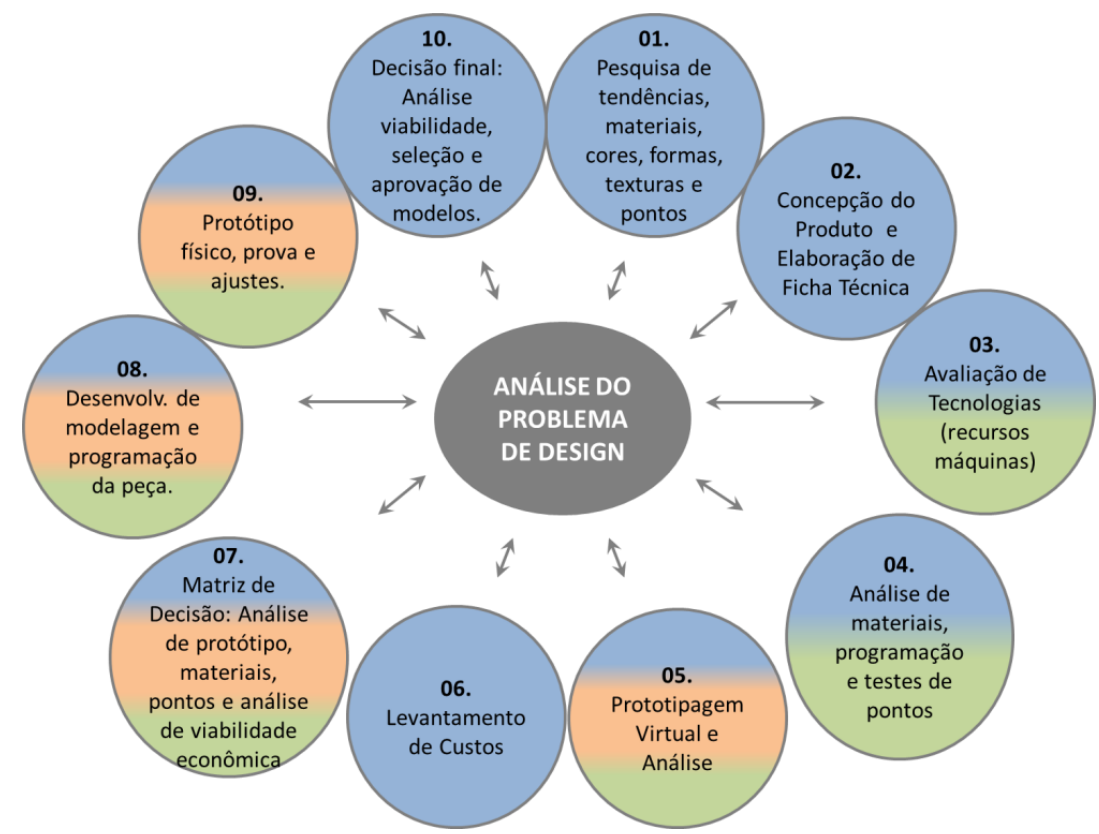

Processo de desenvolvimento de produtos do VMMR Radial (elaboração da autora), baseado no modelos MAPP-3A, Fonte: MAPP-3A, 2010. As áreas 01, 02, 06 e 09 (azul) são

responsabilidade do estilista ou designer de produto; as áreas 03 e 04 (verde) são do programador de máquina com interferência do estilista; e as áreas 05, 07 e 08 (rosa) unem estilistas, programadores e modelista.

\section{A) Fabricante de máquinas retilíneas Stoll}

\section{- Entrevista Diretor da Paramalhas Stoll.}

Entrevista com o Sr. Carlos, Diretor da empresa Paramalhas Stoll Brasil, sobre a iniciativa da revendedora de máquinas retilíneas Paramalhas, em constituir uma empresa de prestação de serviços - laboratório de desenvolvimento de Produto em VMMR denominado Prepara. O laboratório foi montado na sede, em Caxias do Sul, com profissionais preparados para desenvolver o estilo, a modelagem e a programação em alto nível de qualidade e atualização.

“Os clientes gastam muito tempo de máquina para fazer as pilotagens e as máquinas deixam de produzir muitas peças. A primeira estratégia de venda deste serviço seria fazer teste em 
empresas de grande porte. Chamamos um cliente piloto e, por ter uma equipe muito eficiente no desenvolvimento dos produtos, não achou interessante a proposta. Mudamos a estratégia e passei a oferecer programas mais complexos desenvolvidos pelo centro de desenvolvimento da própria Stoll. Eram informações mais atualizadas de moda e de tecnologia. Pesquisamos os clientes grandes sobre os custos de desenvolver programas e quanto custava à equipe de pessoas em desenvolvimento de produto de VMMR. Eles responderam que o custo era altíssimo. Montamos uma equipe com duas modelistas especialistas fazendo os moldes programando todo o processo com as estilistas e programadores. Ofereci a equipe para que, as empresas livres do trabalho de pilotagem, pudessem cuidar da produção e gestão do negócio. Trouxemos várias empresas tradicionais para o laboratório, mostramos nosso trabalho. Fomos muito elogiados, porém, o retorno financeiro foi nulo. Fomos para as de pequeno porte e, trabalhamos com programas que podem ser desenvolvidos para um ou mais modelos. Oferecíamos vários croquis com o mesmo programa para que pudessem ser utilizadas várias vezes com poucas modificações. $\mathrm{O}$ valor era praticamente simbólico, com intuito de ganho no volume. Também não obtivemos sucesso, pois esses pequenos clientes alegavam poucos recursos para a área de desenvolvimento e que era mais barato copiar. Então tentamos trabalhar a visibilidade do negócio, de forma mais institucional através de estilistas renomados, participantes das semanas de moda. Todos ficaram encantados com as possibilidades do produto de VMMR. Mas também, não houve um retorno significativo para a empresa. São estilistas sem produção própria, com foco no marketing pessoal e não no produto em si”.

Conclusão - "Por sermos uma empresa que vende máquinas, softwares e dá suporte a esses equipamentos, os trabalhos de desenvolvimento baseados em tendências de moda não eram associados a nós. Nossa marca estava associada a oferecer cursos de programação e a tecnologia de máquina. Porém, com este forte empenho em oferecer os serviços, com conceito de moda, aliado ao desenvolvimento de matérias-primas e ao bom gosto, acabaram quebrando o paradigma técnico e passamos a ter reconhecimento também nesta área. Passamos a dar consultoria específica para novos clientes e o mesmo aconteceu em vários laboratórios que foram abertos com o mesmo fim em vários lugares da Europa”.

Comunicação da equipe de desenvolvimento de Produto - "O cliente entende que esse processo de desenvolvimento de VMMR na empresa é interessante, quando tem bons resultados e consegue criar uma vantagem competitiva. Obviamente não tem interesse em 
divulgar esse trabalho, pois são os resultados de muito esforço e investimento financeiro. Eles não dizem como funciona. $\mathrm{O}$ cliente pensa que tem bons resultados e teme perder a vantagem competitiva, seu diferencial. Normalmente se escuta isso do cliente que prefere copiar e que está iludido com uma vantagem que na realidade não existe, pois o diferencial é de quem efetivamente criou. Quando pergunto se posso usar algum modelo para divulgar a tecnologia ou algum ponto novo, eles sempre negam. As empresas maiores e mais estruturadas crescem porque investem nesta área (pesquisa, prototipagem, amostragem, matérias primas diferenciadas, etc.). As pequenas empresas preferem copiar peças das empresas mais estruturadas, ou acabam pedindo aos estilistas contratados que desenvolvam modelos que não necessitem alterações nos programas de máquina já existente, o resultado final acaba sendo frustrante e pouco rentável”.

Importação dos produtos de VMMR do mercado asiático - "Normalmente, a indústria nacional não perde pedidos para as importações, mas indiretamente o mercado é afetado. A informação que chega é que a produção nacional não consegue atender a demanda interna desse tipo de produto. Em recente visita ao Brasil, um diretor da nossa representada Stoll que trabalhou muitos anos na China e conhece bem o perfil dos fabricantes afirma "Os fabricante Chineses tem condições técnicas e estruturais de produzir sweaters em tricô com muito mais qualidade e por preços infinitamente menores que os operados no Brasil”. Temos um crescimento invejável nessa área no Brasil devido às margens de lucratividade que são aplicadas a produtos de qualidade e design sofríveis. Quando uma ou duas estações dão certo, iniciam-se as reformas dos galpões, aberturas de novas lojas próprias e a compra de equipamentos financiados em longo prazo ou subsidiados pelo governo. Nesse momento, desaparece também a intenção de investir em design e qualidade, pois a demanda é maior que a oferta e o retorno já estão "garantidos". Na Paramalhas estamos sempre inovando e buscando novas alternativas. Com base nisso é que começamos um movimento forte em direção à tecelagem técnica. Máquinas especiais para aplicação em estofaria automotiva, linha office, home décor, medicina terapêutica e esportiva, calçados esportivos e composites. $\mathrm{O}$ principal motivo do fechamento das malharias é o stress causado pelo ritmo frenético que a moda impõe. Mudanças constantes e um empreendedorismo sufocado por regras governamentais complexas completam o quadro de motivos que muitas indústrias fecham. Vamos continuar apostando, pois sabemos que nesse país a criatividade e o empenho das pessoas é que faz a diferença!". 


\section{- Programado - Stoll - Marcio, Monte Sião.}

Estilistas - A diferença dos modelos desenhados pelos estilistas da região é a fonte da pesquisa de moda, mas não vejo inovação. Muitas vezes são cópias de peças já lançadas por grandes marcas, com pouquíssimas alterações. O relacionamento entre estilista e programador é muito difícil, afirma: "O cliente compra um desenho do estilista e passa para o programador. O desenho vem com pouquíssimas explicações de ponto". Exemplo: "rendado" - pode ser qualquer rendado - Na máquina existe uma infinidade de rendados no banco de memória. Fazem-se várias bandeirinhas, para ter o toque e visual de opções de rendas, e o cliente escolhe a opção que se adapta melhor a ideia do estilista. O programador acaba fazendo escolhas sozinhas, por falta de preparo por parte do estilista. O programador trabalhou com um estilista em um desfile para o Fashion Week, em 2011, e afirma: "Quando o estilista sabe o que quer e fica junto com o programador, as coisas acontecem. Eu tecia um tecido de malha quadrado e ele ia espetando e moldando o tecido no manequim e a peça saia (moulage). $\mathrm{O}$ estilista ajustava a peça, de acordo com ideia do modelo desenhado, e aprovava a peça. Uma vez aprovada a peça desenvolvia-se a modelagem, e depois era a etapa de fazer a programação e tecer a peça”.

Modelagem - Na maioria das empresas, a modelagem não tem tabelas de medidas padrão de tamanhos. Normalmente, tece um tecido de malha quadrado, envia ao cliente para cortar e trabalhar a ideia da modelagem idealizada. Muitas vezes eles usam o programador como modelista. Alguns programadores independentes tem uma piloteira que monta a peça e ele leva a peça piloto pronta para o cliente aprovar antes de programar a peça na máquina para não desperdiçar tempo.

Programação - Com a experiência de 32 na simulação do tecido na tela do computador consegue-se prever o caimento do tecido e saber muito bem como será o resultado da peça. Normalmente não se utiliza o sistema wholergarment, ou peça pronta. A programação deste tipo de peça é muito demorada e dependendo do ajuste é necessário refazer todo o programa. As medidas necessárias são muito mais detalhadas na peça pronta como: comprimento da manga, largura de punho, largura de antebraço, de cava, de bíceps, altura de cava, profundidade de cava, ombro, profundidade de ombro, gola, profundidade de gola, altura de gola, quadril. Sobre as técnicas de jacquard, explica que " São quatro técnicas de fazer: Listado, picado, dupla face e com rede. O jacquard normalmente é feito de duas cores a quatro por carreira. Nas máquinas mais atuais, pode ser feito combinações com 16 guia-fios 
por 16 cores diferentes o que resulta em estampas muito elaboradas. Na técnica de intarcia pode-se usar até 32 cores”. Sobre Visualização virtual, 3D “Existe um software chamado Sirix, com uma família de modelagem - casaco, blusa, etc. - base para visualizar a peça. Criase um ponto e coloca dentro do modelo. Esse software é vendido separadamente e seu uso é um simular ao usado no simulador de tecido que a maioria dos programadores usa, é um software que permite visualizar o padrão de pontos e desenhos antes de tecer a amostra". Nas empresas pequenas não é feita a reunião de aprovação da peça. $\mathrm{O}$ estilista passa pelo gerente de produto e ajusta e aprova. Quando a empresa tem um porte maior é feita a reunião com o estilista, modelista, programador da peça junto à direção de produto.

\section{- Gerente de Marketing - Monica, Stoll, Monte Sião.}

Estilistas - A entrevistada afirma "Existe uma falta de qualificação por parte dos estilistas e programadores na comunicação dos detalhes de estilo e modelagem. O problema é a falta de preparo técnico do estilista".

\section{Sobre o esquema de desenvolvimento de produto em etapas:}

Etapa 1 - Explica que em Monte Sião, é o dono da malharia que faz esta pesquisa. As malharias são pequenas produtoras que tem no máximo oito máquinas. Em Jacutinga as indústrias são maiores e o processo é mais parecido com o Sul do Brasil, geralmente são contratados estilistas que acompanham as tendências, buscam novos pontos e modelagens.

Etapas 1.2.3 - São feitas ao mesmo tempo. Faltam profissionais qualificados que entendem de partes técnicas, que consigam passar a concepção e esboço para o programador, assim como a modelagem. A modelista, o dono ou gerente de produto esta presente nesta etapa para aprovação. Muitas vezes, não é feita esta reunião porque não existem os três profissionais. Em pequenas empresas este processo é feito entre o dono e o programador. Nas empresas maiores normalmente é feita as duas reuniões, na concepção e na aprovação.

Etapa 4 - o custo é dividido em duas etapas: tempo de tecimento e custo de fio.

Etapa 6 - Etapa matriz de decisão - Prova e ajustes, aprovação. Matriz de decisão - Para pequenas empresas as etapas são encurtadas, mas nas grandes empresas usa-se o modelo estendido. Não existe uma avaliação, desde vendas pontuais e, muitas vezes, um modelo que demorou muito tempo de desenvolvimento, é descartado. Atualmente a moda dos tecidos rendados, imitando a renda arrastão em máquina grossa, os programadores praticamente desenvolvem os pontos e apoiam ou até substituem os estilistas, por conhecerem os recursos 
criativos de pontos que a máquina oferece. Exemplo o M1 Stoll foi desenvolvido junto com os programadores e estilistas, para ser um software de programação com linguagens que traduzam a mesma ideia, uma real e uma técnica. Os alunos da Têxtil e Moda, futuros estilistas da EACH-USP, que vieram conhecer os nossos programas aqui em Monte Sião, ficaram encantados com a palestra do programador Demétrius. Porque eles entenderam como funciona a programação, a linguagem do Software. Eles acompanharam as explicações e entenderam, pois já possuem um nível de conhecimento adequado, adquirido na Universidade. O cliente local de Monte Sião, principalmente a grande maioria de pequenos empresários, é amador e tem competência mercadológica com pouco preparo de tecnologia. Os estilistas e modelistas locais não tem esse preparo principalmente porque a clientela não sabe como exigir este conhecimento. Algumas empresas tem este desenvolvimento de produto bem evoluído. Porém, não dissemina, pois fica como diferencial do produto no mercado. Existe a necessidade de montar um curso de estilo e modelagem a nível técnico na região.

\section{B) Profissionais do Fabricante de máquinas retilíneas - Shima Seiki}

\section{- Sergio, Shima Seiki, São Paulo}

Estilista - Esse software pode ser uma ferramenta de estilo no desenvolvimento de produto, ajuda a visualização virtual da peça. Porém, ele também tem seus limites, o caimento real da peça vai ser conseguido depois da peça tecida e provada no manequim. O programador tem que ter um bom gosto, uma experiência e sensibilidade para entender a ideia do estilista. $\mathrm{O}$ ideal é o estilista ter conhecimento do sistema APEX. Nos países mais desenvolvidos na criação de produtos de VMMR existem escritórios especializados em criação de estilo e modelagem com esse sistema. Os biros vendem parte da coleção de modelos em design com as possíveis matérias primas e muitas vezes a programação. Normalmente, o desenvolvimento de produto envia fotos, arquivos etc. Você tem o visual com tensão, formas do corpo, texturas possíveis do fio. Tudo isso desenvolvido, essa é a tendência que estamos direcionando de venda desse produto.

Programação - A maioria dos programadores são free lancers e fazem as peças de um modo particular. Às vezes demoram muito tempo para programar uma peça, por desconhecer os recursos que o programa oferece. Quando se faz a simulação no manequim virtual, temos também a percepção de como os diferentes tecidos caem e se distorcem no corpo. 
Dependendo da matéria prima e do ponto escolhido o caimento do tecido muda muito. Às vezes tem que se mudar a matéria prima, ou estudar um ponto que traduza a forma que o estilista idealizou. No programa de simulação virtual para estilo, percebe-se a sensação de conforto, ele mostra aonde o tecido tem mais tensão no vestir da peça com ilustração por cores. Essa é uma nova tendência de vender das empresas, além de vender máquinas, também vender os programas para facilitação do uso de equipamentos para desenvolvimento de produto. As malharias podem funcionar ficando independente da criação, com sistema de programação e desenvolvimento de escritórios independentes. O estilista necessita um mínimo de conhecimento do fazer manual para criar produtos e entender a modelagem e programação. Normalmente, os programadores vão evoluindo com a experiência e obtendo algum conhecimento de modelagem e estilo. As modelistas e estilistas não chegam a assimilar muito bem esta área técnica de programação. A vantagem destes softwares é conseguir fazer um desenvolvimento de produto com uma estrutura de pessoas reduzida, o sistema tem recursos de visualização muito bons, economizando tempo de programação.

Máquinas Retilíneas - Os três processos de tecimento de peças de malha tem sempre o punho no final da peça, que caracteriza a peça de malharia retilínea: Panos em painel cortam as cavas e gola; Panos calados; Peça Pronta. As máquinas retilíneas possuem diferentes Galgas ou Gauge; no Brasil fala-se em Finura. Ela vai de espessura de muito grossas, como a finura três, até a finura 18 muito sutil e finérrima. A galga ou finura é medida em polegada, que corresponde a aproximadamente 2,4 polegadas por centímetro. As máquinas também, podem se diferenciar por serem de uma finura ou podem abranger mais que uma finura, e são chamadas de Multigalgas. As multigalgas têm agulhas diferenciadas, são mais largas e comportam fios mais grossos, e podem produzir tecidos de malha com um intervalo de três diferentes finuras como, por exemplo, de número 5, 7 e 8 . As agulhas mais grossas tem um gancho da agulha, com o mesmo princípio. Também se usam desagulhar as máquinas, ficando uma agulha sim, outra não, para usar fios mais espessos e produzir malhas mais pesadas. $\mathrm{O}$ gancho maior aumenta na largura, e não no comprimento.

\section{Angela - Empresa de consultoria de desenvolvimento de produto, parceira da Shima Seiki, Jacutinga e Monte Sião.}

Pesquisa - Na primeira fase, depois da pesquisa de tendência a estilista pesquisa o cliente do seu cliente. Avalia a pesquisa de tendência ao perfil do cliente final, quem se destina o 
produto, como vive o que ele faz. E só depois começa a concepção do produto e elaboração dos desenhos da coleção. Atualmente, os clientes contratam a estilista porque querem peças diferentes. Ela viaja uma vez por ano para os EUA ou Europa em setembro para pesquisa e confirmação da coleção mais importante para as malharias que é o inverno.

Diferença entre Jacutinga e Monte Sião - Em Jacutinga, o perfil do cliente é voltado para multimarcas, com quantidade direcionada. Em Monte Sião, se trabalha com pronta empresa no atacado e varejo.

\section{Sobre o esquema de desenvolvimento de produto:}

Etapas 1, 2, 3, 4 - As maquinas retilíneas tem um banco de dados que é renovado mensalmente. Essa informação vem do Japão, em forma de peça pronta, casacos, ou em forma de pontos no site (o site é aberto para livre consulta - Consultas em birô, revista de moda do setor e sites de moda). Na concepção do produto pesquisamos principalmente os novos materiais. Para conceber o produto é necessária esta avaliação. Depois de estudar os materiais, que seria a terceira etapa; e em seguida estudam-se, em quarto lugar, as tecnologias, saber que tipo de tecnologia a empresa disponibiliza para fazer este produto.

Modelagem - $\mathrm{O}$ desenvolvimento de modelagem acontece junto com a prototipagem virtual. Dependendo da tecnologia do software. O sistema oferece uma visualização de tecido de malha muito próxima do real, com o fio e pontos. Algumas empresas, além da simulação do tecido de malha virtual, já tem o sistema de visualização da peça em 3D. A modelagem para peças de produtos, com modelagens ou padrões de tecidos diferenciados, usa a Moulage como técnica de construção. Na construção de peças em malharia a piloteia é fundamental na criação, vai costurar, remalhar, acabar o produto. O sistema de peça pronta também passa pela piloteia, para acabamentos como zíper, botão, etiquetas e passadoria. As peças dependendo do tipo de tecnologia empregada a peça é toda calada, isto é, modelagem acabada; inclusive ombros e decotes, porém, ainda é necessário ir para a mesa do corte para juntar a frente, costas com manga, para depois ir para a remalhadeira, fechadeiras e costura. Esse processo é tratado dentro de uma linha de produção da mesma forma, não elimina um processo de separação e junção das peças como no caso do sistema Wholergarment.

Prototipagem virtual - Nessa fase passam-se as informações para o profissional montar o software de prototipagem virtual, em 3D. O primeiro passo é escanear a matéria-prima mostrar exatamente como vai ficar a imagem com o tecido de malha pronto. Desenvolve-se a 
ficha técnica com as medidas, especificações do modelo e a modelagem. Esse sistema permite ver a peça pronta em 3D, para que se saiba como vai ficar o caimento com aquele fio, ponto e modelagem. O sistema 3D resulta em uma simulação virtual do modelo vestido em um manequim em que se visualiza a peça de vestuário de uma forma real em todos os ângulos, ou seja, como se fosse uma filmagem com medidas, volume e caimento. Nós temos uma ideia de caimento, porém, a malha tem um peso que o processo virtual não consegue traduzir exatamente. Depois de aprovada virtualmente, tecemos a peça. Muitas empresas possuem na fábrica os três processos de fabricação - painel, fully fashioned e Wholergarment - de tecimento e dependendo da carga de produção e tipo de tecnologia que o produto pede, um programa de máquina de acordo com o programador da produção, e o estilista adapta o produto neste sistema. Dependendo do sistema necessário desta peça, o fluxograma pode ser alterado. O painel reto sem calado e o painel calado ou moldado deve ser tratado como um só. Os dois tem um processo que passa pela mesa do corte, mesmo que não tenha corte, é necessário separar as partes e juntar as peças. Quando o tecido é painel sem forma ou calado é necessário cortar com molde. Muitas vezes o corte é feito no decote, ombros e cavas, sendo que as outras partes saem pronto de máquina ou semi-pronto dependendo do modelo.

Ficha técnica - Na ficha técnica é especificado o desenho, amostra do ponto que é escolhido na biblioteca de tecido. Os pontos podem ser únicos ou também dois ou mais pontos resultando em mistura de padrões. No caso de desenhos localizados ou estampas com desenhos é muito fácil, eu desenho a figura e amplio e diminuo conforme o design da peça. Quando tenho, por exemplo, a flor e a Poá, eu converso com o programador e vamos criar estilo da peça. Mesmo tendo o banco de dados sempre mudam o desenho para os clientes. Nesse caso não é feita uma reavaliação virtual.

Reunião dos profissionais - A reunião do estilista com os programadores e modelistas acontece sempre na concepção do produto. Os profissionais se reúnem para trocar informações operacionais da peça, a ideia e viabilidade técnica. As informações são passadas para o programador, e feita à simulação virtual e volta para a aprovação do estilista. O estilista junto ao Marketing e o gerente de produto avaliam o produto do ponto de vista custobenefício, mesmo que o tecido não tenha exatamente a mesma espessura ou mude algum ponto, mas economizou $10 \%$ do valor, o produto vai continuar sendo comercial para aquele público. São duas matrizes de decisão, uma no início e outra no final. 
Vantagem competitiva - Segundo a estilista existe uma vantagem competitiva por prestar assessoria a várias empresas. Os resultados são revistos um a um, na prototipagem, provas de roupa e ajustes de modelos. O diferencial é fornecer uma gama maior de opções. Dependendo do cliente faz-se um acompanhamento dos resultados em relatório final por produto, o que foi vendido por empresa e por coleção. É importante para os estilistas, sabermos se estamos no caminho certo, positivando a cada coleção as criações, por linha de produto e cliente.

Custos - Normalmente a estilista pergunta ao cliente, na concepção do produto quanto tempo de máquina pode-se gastar. Divide-se a coleção em peças mais ou menos com 50\%, gastando meia hora (menos tempo) e o restante mais tempo. Faço o mesmo com a matéria prima. Análise de Viabilidade econômica na concepção do produto é muito importante, com a participação do marketing na matriz de decisão, no começo e no final.

\section{- Gerente de programação - Elias - Shima Seiki, Monte Sião}

Tecnologia - Elias afirma que "a tecnologia avança muito rápido e naturalmente começa a existir as barreiras. Hoje o sistema permite, na programação, a partir de um desenho chegar a um resultado rápido e bom, porém, nem sempre o que você idealizou vai chegar ao final. Quando o desenho chega vai para a programação e o resultado é mostrado em simulação virtual na tela com o tecido e modelagem escolhida vestido no manequim virtual". O resultado da peça mostrado no manequim pode ser aprovado ou não dependendo das características pedidas pelo estilista. Na simulação o resultado é muito próximo ao real e podem-se antecipar materialmente muitos fatores idealizados de estilo como combinação de cor, textura e modelagem. Muitas peças são aprovadas no virtual. Ainda existe aqui na região uma barreira para entender e usar este programa em 3D.

Estilistas - Os novos estilistas, que terminam a faculdade, chegam aqui no escritório e em quatro dias já começam a entender o sistema. Nós demonstramos os sistemas e eles começam a manusear sem dificuldades. Estamos falando de Photoshop, Coreldraw, em linguagens que estes jovens conhecem, os comandos são os mesmos que no sistema da fabricante Shima.

Programação-3D - Nas partes mais complexas, os estilistas tem dificuldade de entender o processo de construção da peça na programação. Na simulação de determinadas estruturas, esta parte fica facilitada porque, o próprio sistema tem um banco de dados bem vasto que pode ser visualizado. Não necessita entender de programação para entender a programação virtual. Entrega-se o croqui com sua tabela de medidas e com um pouco de conhecimento de 
modelagem, tem a aquela parte pronta. A modelagem vai se dificultando dependendo da complexidade do modelo. Na prestação de serviços de programação para as empresas da região, os clientes entregam o croqui, o arquivo da modelagem e uma imagem da estrutura a ser desenvolvida. O maior problema é a elasticidade e o peso, as malhas, muitas vezes, tem caimento do tecido de malha que pode sair diferente do molde. Atualmente este problema é resolvido na maioria das vezes pelo programa com um sistema de cálculos resultando uma modelagem muito próxima ao real. Essa foi a primeira barreira no início do desenvolvimento deste sistema 3D. Como por exemplo, de uma peça de modelagem complexa com um fio 50\% algodão e 50\% linho, se mudarmos para uma peça que tenha um fio de poliamida com uma característica de encolhimento a peça vai ter uma deformação de medidas para um menor tamanho. A princípio o tecido apresenta um caimento, uma textura e um tamanho. $\mathrm{O}$ computador vai trabalhar com medidas, em centímetros ou polegadas e com um molde certo vai entender que uma peça de $60 \mathrm{~cm}$ de comprimento e de algodão que tem pouco encolhimento diferente de outra com poliamida que tem um maior encolhimento. $\mathrm{O}$ programador passa os dados para o cálculo no computador, com uma base em um tecido de 10 $\mathrm{cm}$ X $10 \mathrm{~cm}$, com um fio especificado. É feito um cálculo no programa, passado o comando de $10 \mathrm{~cm}$ em $\mathrm{X}$ agulhas, nos mesmos $10 \mathrm{~cm}$ em y eu vou usar tantas passadas. A partir do cálculo, o computador vai distribuir tantas agulhas ou passadas para atingir o número de $\mathrm{cm}$ que é necessário no molde final. Dependendo da finura da máquina ou da elasticidade do tecido, ele calcula o tamanho da peça. Começamos por tecer primeiro uma pequena amostra de tecido de malha para ver a gramatura e textura do fio e a partir desta amostra, começa a criação da modelagem. Uma textura adequada para o programador pode não ser para estilista, esta é a maior barreira de comunicação. No caso de produtos que são commodities ou básicos, normalmente a base de dados funciona muito bem, porém, para produtos diferenciados e inovativos, a criação da peça é desenvolvida sobre o manequim. Por exemplo, nós fazemos alguns desenvolvimentos para uma malharia que criou modelos para desfiles na Fashion Week. Mesmo fazendo com a simulação virtual, eles precisam dos tecidos para sentir o tato, e o caimento. Daquele croqui vai sair às texturas e estudar a viabilidade na máquina, mas o melhor caminho é a prova no manequim.

Máquinas de peça pronta Wholegarment - Na Europa estas máquinas são mais usadas porque eles preferem por matéria prima natural de lã animal, e também o algodão. O custo destes fios é alto, porém, a malha tem uma ótima qualidade e aparência. No Brasil, a peça 
pronta é feita de acrílico e os fabricantes querem produzir a peça da máquina, vaporizar e colocar na prateleira para eliminar os processos produtivos e baixar o custo. A peça pronta elimina os processos. No algodão em cru usado em algumas malharias, a peça pronta é ideal, porém, passa por uma série de processos de tingimento e lavagens e amaciamentos. Este tipo de produto diferenciado encolhe em média 30\% no comprimento e $10 \%$ na largura, a modelagem precisa ser calculada muito bem para não distorcer o produto. Para fazer uma peça em calado gasta-se 30 minutos e mais 20 minutos com costura e remalhadeira. Na peça pronta eu vou gastar 45 minutos, porém, uma peça pronta não tem todos os recursos de uma peça calada, existem alguns limites. No meu ponto de vista a peça pronta é muito mais produtiva porque não tem costuras.

Estilistas - As estilistas tem uma base de moda teórica na faculdade. O maior problema é que elas não conhecem os equipamentos. O estilista não deve saber como eu vou programar a trança, o recorte, as cores. Se o estilista ficar preocupado com as dificuldades técnicas ele não vai expressar a sua criatividade adequadamente. O estilista vem com o croqui e eu vou pensar como resolver esta peça, o fio que vai tecer bem, qual ponto é adequado, e começaram a pensar na tecnologia. Avaliação de tecnologia é primordial para entender se a ideia é viável.

Modelista - a partir do momento que é definida a tecnologia e a matéria prima, são mais fáceis passar para a modelista, mesmo em peças complexas o trabalho da modelista é técnico, e seu resultado depende da experiência do profissional, da exatidão dos dados da peça.

Matriz de decisão - Esta reunião é primordial para qualquer tipo de produto - viabilidade, estatística de venda, para estabelecer uma reunião final. Um retorno com uma reunião para saber o que deu certo e o que não deu certo. Argumentar e observar como foi o caminho deste desenvolvimento até chegar à fabricação. Porém, na comunicação entre os profissionais existe muita dificuldade.

\section{- Entrevista - Pinotti- Distribuidora de Fios Águas de Lindoia.}

Processo criativo - O processo criativo no desenvolvimento de produto vai acontecendo, é aprovado na confirmação de tendência.

Programadores - 98\% dos programadores não têm estudo, nem faculdade, salvo aqueles em que as empresas são fabricantes de máquina, e tem os engenheiros que trabalham dando assessoria de funcionamento da máquina; são as pessoas que realmente tem esse conhecimento de construção de equipamento e tem a base de treinamento tanto na base 
mecânica como na parte eletrônica e, por consequência, programação do equipamento. Os programadores, inicialmente trabalham como tecelão para saber operar a máquina, é necessário saber entender de formação de ponto; saber o que a agulha faz. Ele não precisa saber a modelagem nem o estilo. O estilista leva a ficha técnica com todas as informações, o desenho e a modelagem pronta. Quando a ficha técnica chega, ele analisa junto com o estilista e a modelista os recursos de máquina disponíveis para fazer o produto o mais próximo à ideia de padronagem e modelagem. Os programadores sabem fazer tecidos de malhas bem elaborados, porém, a dificuldade fica na modelagem. As empresas faziam peças quadradas sem corte e com tamanhos únicos. Atualmente as empresas têm investido em modelagens mais adequadas e com graduação de tamanhos. O Tecelão tece a primeira amostra de tecido de malha, passa pela vaporização para estabilizar o tecido e coloca em cima do molde. Caso esteja com problemas de tamanho volta para o ajuste com o programador.

Avaliação de tecnologia - o programador avalia o desenho e adapta a tecnologia. A estilista vai determinar a matéria prima adequando o fio ao produto que ele escolheu: linho, viscose etc. O operador da máquina vai fazer a amostra experimentando tecer o tecido quando necessário ou escolher na sua biblioteca de testes de tecidos prontos. Se forem fios novos ou pontos novos é necessário fazer este teste virtual, ou até real, para entender a elasticidade, devido ao peso e caimento.

Tecnologia - Inicialmente as máquinas eram todas longas entre 2,oo metros e 2,40 metros contendo um, dois ou três sistemas por carro. As maquinas evoluíram de uma carro para dois carros a fim de dobrar a capacidade de tecimento com mais partes da peça de vestuário sendo produzidas ao mesmo temo. Na década de 90 o jacquard colorido estava no auge da moda e esta máquina oferecia uma alta produção nesta padronagem colorida. Em 1995 a empresa Shima Seiki lançou a primeira máquina compacta com 1,20 metros de frontura aproveitando os carros das máquinas longas com a tecnologia de mais sistemas (um, dois ou três sistemas). Foram lançadas máquinas compactas com dois carros e dois sistemas que resultava em 4 sistemas para peças especiais, por exemplo, casacos com bolso. Hoje no Brasil, as malharias estão investindo em novas máquinas compactas para eliminar mão de obra. Um operador consegue trabalhar com seis máquinas ao mesmo tempo. Foram diminuídas as etapas de corte, costura e acabamento. As máquinas de fazer peça pronta têm 1.50, 1.70 e 1.80 metros. As grandes maiorias das empresas usam o painel calado. Peça sai calado com a modelagem pronta, desenhado de acordo com o molde no sistema fully fashioned. 
Foi a grande revolução no modo de tecimento, pois possibilitou que os tecidos fossem feitos já no formato final dos moldes da peça de vestuário. Este sistema chamado Wholegarment, feitos em máquinas de última geração produzem vestuário de malha pronta sem costura.

Programação 3D - O sistema de 3D de modelagem, ainda é pouco usado pelas malharias, tem um custo alto de aproximadamente 50.000 dólares. Algumas malharias de maior porte tem este sistema. Para fazer o tecido virtual e desenvolver as amostras e os pontos e texturas, usam o cardápio de ponto, banco de dados fornecidos pelos fabricantes de máquinas, eles abrem um leque de 80 tipos de trança e escolhe, copia e cola, monta a peça e avalia. Hoje no Brasil, ainda se usa a visualização em painel, e depois é feita a modelagem e montagem da peça no real. $\mathrm{O}$ virtual 3D é peça pronta no boneco, posso visualizar de vários ângulos, virar, observar o comprimento e o caimento, se os pontos estão adequados, ele realmente veste a peça no mais real possível, e com um detalhe. Nos países mais avançados a visualização em 3D de peça pronta acontece há muitos anos. Hoje a impressão em papel da amostra de tecido com ponto trabalhado diferente mostra uma visualização perfeita.

Modelagem - A modelista fornece o molde completo a partir do teste de tecido fornecido pelo programador. Depois de tecida a peça, vai para a piloteira costurar, acabar a peça. O programador precisa ter noção de proporção, altura da manga, de cintura, ombro. A malha é basicamente feita em tubos, para construir uma peça são colocadas as medidas e formas diferentes para encaixar o corpo. Normalmente o programador de peça pronta também vai acompanhar o protótipo na máquina.

Experiência na Itália - Seis máquinas Shima SES122S - produzia peças de cachemira, tinha quatro remalhadeiras, um operador de máquina, quatro pessoas para trabalhar nas máquinas e duas pessoas para finalização - cada máquina dessas produz máquina 12 - 5,400 peças/mês de blusas de cachemira sem corte, com um retorno muito alto. No Brasil, temos corte na peça calada porque os programadores não usam o recurso de máquina. Este é um conceito brasileiro, ele corta o ombro e o decote, para não perder o tempo de esperar a máquina calar. Atualmente $80 \%$ dos produtos são feitos modelados com calados, fully fashioned. Uma máquina nova com este sistema custa acima de 300.000,00 reais, no entanto uma máquina de 20 anos atrás faz o mesmo processo de calado e a peça sai com o custo menor.

Distribuidora de Fios - No Brasil, 95\% do mercado usam 100\% acrílico - Os fios de verão e inverno são iguais, o que difere é a técnica de produção. Ele é a junção de dois fios torcidos de um fio 28 que da $2 / 28$. Um dos maiores fornecedores de fios acrílicos é a Lansul, depois 
vem a Acrilan e fios Amparo. O mercado de fios acrílicos é divido em 50\% em importação e $50 \%$ desses fabricantes citados. O fio acrílico importados vem da China, Indonésia e Índia. O maior produtor de fios acrílicos é a Indonésia. Em termos de matéria prima, como os fios nobres de cachemira, alpaca, angorá, lã de carneiro, o consumidor brasileiro não conhece, e consequentemente não valoriza este produto. E para produzir estes fios naturais são necessárias outras técnicas como lavagem com amaciante correto, que tem emulsão de silicone e precisam de secadoras especiais. A indústria local não investe em produtos diferenciados, o consumidor brasileiro é visual, e não está preocupado com a qualidade do fio. $\mathrm{Na}$ escolhas do importador o foco é no visual diferenciado, bolinhas coloridas, com brilho e efeitos tridimensionais. Outra técnica com um bom retorno nos últimos anos foi a estamparia em sublimação. Esta técnica de estamparia foi feita em cima de um tecido de malha feita com um fio de custo baixíssimo como o $100 \%$ poliéster, microfibra, com um custo de 12 reais o quilo, em cru, e com um peso baixo de 150 gramas. O efeito de estamparia por sublimação (em papel) no tecido resulta em uma estampa com o fundo em pontos de malha com visual bem diferenciado. As pessoas então entendendo que é preciso colocar uma novidade na linha de tricô. Conseguimos acertar no mercado procurando encontrar fios com diferencial, como por exemplo, o fio com paetê.

\section{C) Entrevistadas no polo do Sul de Minas com empresas produtoras de VMMR.}

\section{- Empresa A - PA - Monte Sião}

Empresa de produtos diferenciados a mais de 20 anos no mercado. O processo de fabricação é em painel calado, fully fashioned, tem nove máquinas eletrônicas, não tem máquina de peça pronta, wholergarment. O atacado é com vendas por meio de representantes e varejo com uma loja própria em Monte Sião.

Pesquisa de tendência - mix - público alvo - A concepção de produto é feita com os três profissionais. Feitos o esboço; programação e modelagem; e estilo.

Pesquisa - Em primeiro lugar, começa a pesquisa das vendas passadas, os produtos que venderam mais. Histórico de venda com foco no tipo de produto. Parte da análise de tipo de produtos e suas características que vendem mais, tipo de modelo, quantidade de blusas, saias etc. Estuda o mix de produtos e estabelece as quantidades para cada tipo de produto fechando a coleção em termos de quantidades de peças. Estabelecido este parâmetro é desenhado os 
croquis baseados em: pesquisas de revistas de moda, site, birô de tendência WGSN, viagens a cada seis meses, principalmente na coleção de inverno. A pesquisa é feita com viagens a Londres, Paris, e algumas vezes em Milão. A marca de fora que mais pesquisa - Hevelege, Alexander, Maxmara. Segundo uma das sócias e estilista da marca "Na realidade, nós temos vários tipos de clientes dos mais clássicos aos mais arrojados. Focamos em peças diferenciadas principalmente em modelagens. Produzimos tricô com qualidade, com cortes diferentes e pontos diferentes, acabamos por buscar estilistas mais clássicos em tricô e alguns estilistas mais novos para diferenciar e ter novidades. O que mais os clientes vão buscar na empresa é o diferenciado. Exemplo, um básico com corte legal. Tem algumas peças, cerca de $10 \%$ que fazemos os de vanguarda. Mix fica assim 30\% fashion, $10 \%$ vanguarda, e $60 \%$ clássico que varia com a tendência de mercado. Depende muito como sentimos a moda naquele momento, vai oscilando um pouco. Esse mix tem a ver com o mercado. Na nossa empresa existe um estudo muito importante nas vendas, engessamos o mix (fixamos o mix) e mudamos alguns detalhes. Tudo é com base no tricô e internamente. Eu conheço algumas empresas que já usam o programa de modelagem Virtual que aperfeiçoam esta etapa de desenvolvimento de produto, esboço, modelagem, tudo integrado. Eu tive uma experiência com uma demonstração, mas ainda não comprei o sistema”.

Materiais - Sobre materiais, na pesquisa feita previamente, já são escolhidos os pontos e o fio que vai dar certo neste esboço do modelo. Alguns fios são previamente escolhidos para alguns modelos, esta pesquisa e aprovação tem que ser junto, para resultar em um tecido adequado. O fio é escolhido para determinado ponto, para um tecido adequado ao modelo. São feitos testes de ponto e testes de modelagem simultaneamente. São feitas quantas provas necessárias para a aprovação do tecido com o fio escolhido para fazer a modelagem daquela peça piloto e provação final. As bandeiras de amostras de cores e texturas são feitas depois da aprovação dos pilotos.

Modelagem - A modelista está junto com o desenvolvimento de produto e programação. Ela não participa na decisão de viabilidade econômica. Na programação, depois de aprovado o desenho, executa-se o molde e acompanhado pelo programador. Depois ela volta na prova e ajuste com o estilista. A empresa ainda não usa o programa de modelagem virtual. Programação - A programação é feita com base no esboço do modelo e desenvolve a modelagem. Com esta modelagem, calcula a quantidade que é necessária para tecer o pano e, 
então, vai ajustando na programação da modelagem. Para iniciar a programação é necessário já ter a modelagem aprovada. Os dados são lançados no sistema e sai o primeiro piloto.

Custos - Na primeira peça piloto, são lançados os dados na ficha técnica de tempos de programação, tecimento e matéria prima para o calculo dos custos. Dependendo desses tempos, se forem muito demorados, tenta-se abrir novas possibilidades para salvar ou descartar o modelo.

Ficha técnica - acompanha desde o esboço. E isto é um fator importante no momento da aprovação da peça piloto e compra dos materiais e confecção da peça. Tudo vai sendo adicionado na ficha técnica, desde os mínimos detalhes e quantidades: fios, linhas, botões, fitilhos, elásticos, etiqueta, aviamentos, detalhes, outros materiais, etc. Assim como, a mão de obra e trabalhos diferenciados, se não é pensado e aprovado antes, pode impactar a produção depois. Depois de aprovada, a ficha vai ser a base de dados para os custos e para a produção.

Reunião de aprovação do modelo - É feita uma reunião com a estilista, a gerente, o programador (mais voltado para o tempo) e o consultor da empresa - que também é o gestor financeiro (O gestor de uma empresa contratada, para dar a consultoria de gestão que faz o papel do financeiro). Segundo a estilista "a decisão final das escolhas dos produtos na coleção é da direção da empresa. Às vezes, o modelo sai a um preço muito alto, mas nós aprovamos porque ele é maravilhoso. Isto faz parte da estratégia da empresa. Mesmo que não venda, mas tem a função de mostrar a diferenciação da empresa, sua qualidade e inovação. Estes produtos são os que menos vendo e com o menor retorno financeiro, porém, é o que torna a nossa marca mais elitizada e fashion. Meu cliente espera este produto da empresa, ele é a vitrine, ele chama a atenção. Dependendo do tempo de máquina monta-se uma estratégia para minimizar custos e ter um bom resultado, vamos sentindo pela experiência de mercado o que deve ser aprovado, fazendo a ficha técnica e produção. O nosso ponto forte é investir em qualidade e design, moda e inovação, pesquisamos o tempo todo para sair na frente. Usamos todos os recursos e materiais possíveis para enriquecer as peças como; bordados, estamparias, aplicação, metal, mistura de tricô com tecido, couros e peles. O que mais impacta no preço é o tempo de produção, se um tecimento de uma malha demora 2 horas, vai para o acabamento e demora mais duas, temos um trabalho artesanal. Nós contratamos um consultor para ajudar a gerir a empresa e controlar nossos custos. Neste próximo ano, estamos estimando um crescimento de $20 \%$. Apesar da crise e falta de fios". 


\section{- Empresa B - IMA - Águas de Lindoia, SP}

A empresa está há mais de 15 anos no mercado e é a maior empresa na região de Monte Sião. Atende principalmente o Estado de São Paulo com uma pronta entrega e por venda pela internet. Esta empresa é administrada por três sócias irmãs, que dividem as áreas de produção, vendas e desenvolvimento de produto. Tem aproximadamente 100 funcionários, e conta com aproximadamente 30 máquinas retilíneas eletrônicas muito atualizadas que produzem aproximadamente 50.000 peças por mês. São comercializados principalmente casacos e blusas para o feminino na estação fria de inverno. No verão, o mix de produtos é voltado para peças de malharia circular e tecido plano, com apenas uma pequena parcela de blusas de malharia retilínea, sua grande produção são vestidos e blusas de viscolaycra, e outras malhas planas e tecidos planos. Subcontrata parte da produção de costura (para mix de tecidos planos e malhas circulares) Planta industrial em Águas de Lindóia; e três lojas, duas em Monte Sião e uma (matriz $-500 \mathrm{~m}^{2}$ ) em Águas de Lindóia. Venda através de lojas próprias (atacado e varejo), e de revendedores autônomos por todo o território nacional. Produto para o público feminino, voltado para classes B e C.

Programação e tecnologia - $\mathrm{O}$ departamento de desenvolvimento é composto por três programadores. Têm equipamentos muito atualizados, os produtos são todos fabricados em fully fashioned, eles não trabalham com máquinas de peça pronta. Dentro da tecnologia de fully fashioned, utilizam máquinas de multigalga. Segundo o programador desta empresa, as máquinas multigalgas, tem uma construção de agulhas e dispositivos mais resistentes para poder aguentar a tensão das diferentes finuras e que resultam em uma melhor qualidade de malha tecida com menos defeitos.

Ficha técnica - A ficha técnica desta empresa é bem simples, o estilista basicamente fornece um croqui do desenho do modelo, a galga, cores e tipo de ponto. Todos os ajustes dos dados técnicos são desenvolvidos com os programadores que produzem a peça junto a supervisão das sócias.

Estilistas - Uma das sócias comanda a parte de estilo e se apoia em estilistas free lancers. As escolhas dos modelos é feita pelas sócias, assim como toda a parte de publicidade, campanhas, escolha de temas e inspirações para a coleção. Os novos desenvolvimentos de VMMR são escolhidos em reuniões periódicas, para a escolha de temas e modelos, e acompanhados por consultores de marketing. As peças pilotos são produzidas junto aos 
programadores e modelistas e normalmente esta empresa investe nos recursos tecnológicos das máquinas nas texturas e cores. A empresa tem a característica de focar um público médio das classes sociais $\mathrm{B}$ e $\mathrm{C}$, com produtos mais elaborados com acabamentos pronto de máquina que dispensem retrabalho posterior.

\section{- Empresa C - MM - Monte Sião}

Empresa com 20 anos de experiência fabrica produtos com qualidade e fios diferenciados. A MM começou suas atividades em 1978. A malharia cresceu nestes 20 anos e tornou-se exemplo de qualidade e diversificação de produtos. Ela tem uma política de vendas e desenvolvimento de produtos focado na necessidade do cliente. Esta malharia investe na demanda do mercado de moda, que a partir do desenho da marca, a fábrica vai desenvolver o produto. O fabricante afirma que a maior ameaça para o crescimento da empresa é a importação dos produtos da China e o alto grau de informalidade das malharias na região.

Desenvolvimento de produto - "O custo de desenvolvimento de um produto de malharia é muito alto, e só consigo diluir este custo produzindo uma quantidade grande de produção pois temos ainda que acertar na programação tamanhos e cores. A média por modelo são 500 peças divididas em duas ou três cores. Os atacadistas e magazines compram mais de 1.000 peças por modelo".

Estilistas - a peça piloto custa em média R \$ 600,00, passando pelo estilista, modelista, programador, máquina e acabamento. Este valor estimado é aproximadamente o que os birôs cobram no polo do Sul de Minas. Uma das estratégias que o empresário pensa em seguir é lançar cada vez mais modelos, com quantidades menores e com diferenciação. Segundo o empresário é preciso encontrar fórmulas de resolver de maneira adequada o que o estilista desenha como tendência da estação. Esta diferenciação passa pela matéria prima, padrões, modelagem, cor e adereços. As lojas, muitas vezes, não conseguem enxergar os defeitos nos produtos, pontos e costuras tortas e mal feitas. Dentro das escolas de moda quase não existe este conhecimento técnico de tecimento e modelagem em malharia retilínea. Existe uma necessidade eminente de passar estas experiências para os futuros estilistas, compradores e toda a cadeia têxtil, sensibilizando estes clientes a dar maior valor para este segmento. Ele afirma que "O maior problema comercial na apresentação e venda do produto para o varejo é que os estilistas compradores das marcas não tem conhecimento sobre o processo de malharia retilínea e eles confundem com o processo do tecido plano". Os compradores não avaliam a 
dificuldade de projetar e executar a malha, no tecido plano pode infestar (sobrepor um tecido sobre o outro) ate 500 folhas e o tempo de infestar e cortar é diluído pela quantidade de peças. Uma máquina pode produzir em média 20 peças por dia, tem características diferenciadas de elasticidade e peso no seu processo produtivo. Os adereços ou trocas de cores e padrões requerem estudo e tempo de manufatura. A empresa é totalmente focada para o alto inverno e antecipa a produção para o verão, as malhas do próximo inverno.

Matéria-prima - Os fios são fabricados por diversas indústrias nacionais e também podem ser importados dependendo da demanda e custos da época. Atualmente, as fábricas de fios brasileiros já têm muitos fios diferenciados e de boa qualidade, comparada a de outros países mais desenvolvidos nesta área, como a Itália. Segundo o empresário da MM, um fio com composição de $100 \%$ acrílico, chega em $2 \%$ de variação de diferença de tamanho para tamanho, e um fio de poliamida chega até $15 \%$ de variação de tamanho para tamanho. Cores mais densas como o preto costuma encorpar a malha, o que distorce consideravelmente o tamanho da peça. Por exemplo, uma malha tecida com $12,5 \%$ de tensão em preto, em um determinado fio para ter o mesmo tamanho no vermelho, pode precisar ser tecida a $13 \%$ de regulagem em vermelho e bege na regulagem $12 \%$.

Tecnologia - O fator mais importante no processo da VMMR é o tempo de tecer os tecidos de malha. As máquinas eletrônicas necessitam de programadores experientes, tem um custo alto e são complexas de se utilizarem. Estas máquinas normalmente funcionam 24 horas por dia em três turnos. Dependendo do fio como, por exemplo, um fio do tipo mousse, que é mais espesso e frouxo, a produtividade cai para $60 \%$. Se for fazer um trabalho com pontos abertos rendados com furos, a produção cai, e com um aumento de $25 \%$ do tempo.

Profissionais - "Falta de profissionalização e é alta a rotatividade da mão de obra. As empresas tem um custo alto de treinamento e sempre estão correndo o risco de perder os funcionários, pois neste polo especifico de Sul de Minas, existe mais de 6.000 empresas similares o que resulta em quebra de produção e custos mais elevados".

Programação - Dependendo das características apresentadas pelos fios empregados, e pelos padrões escolhidos nos modelos do VMMR, resulta em muitos programas para o mesmo modelo. Custo - Ele afirma que antes de lançar novos produtos, faz-se necessário analisar e estudar sobre os recursos gastos, para desenvolver os modelos. O fabricante relata que a peça em malharia retilínea vai ter mais valor, dependendo do visual que ela apresenta, sendo assim este 
valor é subjetivo. Na entrevista ele diz: "Mas podemos afirmar que, quanto mais complexo o desenho e suas customizações, mais valor agregado ela vai ter”. Uma máquina que custa $\mathrm{R} \$$ 300.000,00 leva 40 minutos para tecer uma peça que trabalha em três turnos. O valor agregado desta peça é diferente do valor de uma peça de camiseta de tecido de malha circular ou tecido plano.

\section{- Empresa D - RO - Monte Sião}

Empresa familiar com três sócios. Está no mercado há mais de 10 anos. A empresa R.O., fabrica basicamente blusas básicas de inverno, abertas ou fechadas em decote V e Careca. Comercializa seus produtos em atacadistas oferecendo produtos básicos para o inverno com qualidade e preços baixos. Tem aproximadamente 10 funcionários.

Estilo - O fabricante descreve: "Trabalho com produto básico, que é feito a partir de painéis que são cortados em pilha, como no tecido plano de no máximo 20 partes por vez". Todos os processos com qualidade. Os fios são diferenciados com até 4\% de elastano. Os maquinários utilizados são os usuais em malharia, máquina de costura, fechadeira, overloque, etc... O diferencial desta empresa é que, na maioria dos produtos, eles fazem painéis com ou sem diminuição ou calados na mangas, dependendo a tecnologia empregada. O decote sempre é cortado por meio de enfesto com máquina de corte como na malharia plana. Eles costuram o acabamento no decote em máquinas de costura, usam a máquina de duas agulhas com regulagem para este tecido de tipo PT no decote, muito bem feito. O resultado é que os produtos são básicos, commodities, não necessitando de moda no design de produto.

Modelagem - Faz-se necessário deixar a malha descansar por algumas horas, até estabilizar os encolhimentos. Partindo de medida final estabilizada se chega o tamanho desejado diminuindo ou aumentando as medidas. A maioria dos produtos são confeccionados com $48 \%$ acrílico, $48 \%$ viscose, $4 \%$ de elastano; chamado de Frex Strech, que é um ótimo fio para fazer malhas finas e básicas. A empresa atualmente esta testando a porcentagem de fio que contém 96\% acrílico e $4 \%$ elastano, por ser um fio de custo mais baixo. A dificuldade deste fio é chegar a uma estabilidade que possa ser programada mantendo sempre o mesmo padrão. Como este produto tem alto descarte, Ronaldo começou a guardar as sobras que compensavam para fazer uma peça, na hora que chegava a época de baixa estação, sem produção. Nas épocas de produção baixa, eles faziam uma nova peça que podia ter até 20 amarrações de fios, porém, disfarçados com listinhas. As peças listadas tem menor valor 
comercial que a peça de uma só cor. Uma máquina tem em média nesta malharia um descarte de cinco peças por dia em uma produção de 50 peças por dia, 10\% de perda. Depois de experiências feitas com sobras, ele esta desmanchando as peças de descarte no mesmo dia e reaproveitando com os próprios funcionários, sendo assim evita-se espaço de estocagem e rapidez no retorno financeiro.

\section{- Empresa E - PE - Socorro}

O produto principal é malhas para o público masculino clássico, com base de fios em algodão e processos de lavagens diferenciados de moda, produtos com qualidade mais elaborados e também básicos. Produção anual aproximadamente de 50.000 peças, 40 funcionários; 5 máquinas interno. Possui equipe interna de uma estilista, um programador, uma modelista, o gerente é o empresário da empresa. A empresa tem três lojas com marca própria, e também, trabalha com sistema de pedidos para varejistas com coleções desenvolvidas para o inverno e verão. No verão, a empresa trabalha principalmente com malha plana de malharia circular. Desenvolve modelos exclusivos enviados por clientes diferenciados com ótima qualidade.

Estilista - O processo é desenvolvido pela empresária e pela filha que é estilista. Pesquisa-se o público que quer alcançar. A pesquisa é feita no mercado europeu que está uma estação a frente. Foco nas marcas que se identifiquem com seu público como a Harolds britânica e a espanhola El corte Ingles, duas lojas de departamento que comercializam as melhores marcas deste segmento na Europa. Também pesquisam outras fontes como: informações de tendência na internet, sites de moda, empresa de consultoria da região. Baseia-se na análise da coleção anterior, histórico de venda para entender quais os produtos mais vendidos e continuar criando na mesma modelagem outras versões com cores, formas e texturas mais atualizadas. Cores mais vendidas, escolhas de cores clássicas e introdução de uma cor de moda da estação. Além de algumas peças criadas internamente, adquirem desenhos de estilistas locais.

Concepção dos modelos e avaliação de tecnologia - A empresária analisa os dados e faz reunião com estilista e programador para a escolha do programa. A empresa tem um sistema de programação com simulação de imagem virtual em 3D. Este sistema torna viável a simulação da peça, tanto em cores e padrões como no caimento do tecido de malha no corpo, muito próximo do modelo da modelagem proposta. A sócia gestora detém conhecimentos de programação, utiliza a infraestrutura das empresas fabricantes de máquinas para se atualizar e contam com um programador e uma modelista em tempo integral. 
Tecnologia - É tecida as amostras de tecidos de malha com os materiais, pontos e trabalhos escolhidos. Uma vez analisado e escolhido o padrão do tecido de malha passa-se para o computador o desenho da peça e a receita da modelagem de acordo com a amostra que vai encaixar na modelagem virtual. Em seguida passa pela avaliação de custos e escolhas dos modelos. Normalmente a decisão é feita com reunião da estilista e gerente de vendas.

\section{- Empresa F - GA - Monte Sião}

Estilista - A pesquisa é feita com 4 a 5 meses de antecedência de tendência: escolhas dos desenhos, escolha de fios, decisão de produto, o que é mais produtivo, e os preços dos fios. Pede-se 10 quilos de cada fio que interessa, e o modelo é desenhado. Pesquisa-se os modelos mais vendidos. Na maioria das vezes os clientes é que trazem os modelos para desenvolver. Primeiro, pesquisa-se os clientes parceiros que conhecem a tendência de moda no mercado, para depois fazer a coleções. Muitos desenhos forma comprados por uma estilista com experiência em malharia, com desenhos muito detalhados e indicações de pontos e cores. Depois, em 2007 veio a Laura que entendia de modelagem e de moda, desenvolvia-se uma coleção de 40 a 60 modelos para clientes específicos.

Tecnologia - De acordo com o modelo, tinha painel, peça pronta, painel com calado. Não tínhamos programação virtual, mas com base no histórico de produtos feitos e com a experiência, já se sabe antecipadamente os custos e como a peça vai ficar.

Análise de materiais - Era necessário fazer as bandeiras para ter uma ideia da cor e textura da peça. Fazia-se a receita da modelagem da peça em cima desta bandeira. A empresária explica "Mede-se em centímetros, quantas carreiras vai usar no comprimento, o tamanho da cava, altura da cava... Exemplo é $23 \mathrm{~cm}$, você conta quantos pontos tem nesta cava e quanto você vai diminuir com o apoio da bandeira. Joga a sua modelagem em cima da bandeira: tamanho de frente, costas... Nem todo programador entende nossa linguagem, nós é que passamos a modelagem muito bem explicada para ele. Você mede o ângulo que tirou e vai multiplicando até fazer o contorno da manga que é resultado dos calados. Temos uma trança e não sabemos aonde inserir? Pega o centímetro, mede as distâncias em quantidades de pontos na bandeira e temos o resultado. Trabalhamos sempre com o centímetro. O Ricardo, meu programador na época, era muito bom, fez cursos de treinamento na Alemanha. Eu requisitava uma amostra com mistura de fios, por exemplo: 10\% lurex, 20\% moliné e 70\% de um fio acrílico. Os três cones eram pesados e o programador tecia o pano com a medida certa 
do molde. Conferia, depois de tecido, quanto exatamente foi consumido na medida certa e passava para a ficha técnica. Toda ficha técnica era escrita com referência, tempo de tecelagem, peso, produção de acabamento, e todos os processos de acabamento".

Modelagem - Segundo a empresaria que é especialista em modelagem "em primeiro lugar a partir do desenho aprovado, faço o molde, analiso todas as medidas de acordo com as listras, cores e trabalhos. Desenho tudo no molde, e envio ao programador. Você tem o molde básico, e em cima dele você vai colocar o bolso, os desenhos e detalhes. Normalmente tem ajustes, tem programa que é necessário ajustar de quatro a cinco vezes. Teve épocas que eu fazia 20.000 a 30.000 peças de um mesmo modelo, e com uma produção de 15.000 peças/mês. Quando a estilista entrou, comecei a diversificar em modelos, a produção caiu para 5.000 peças por mês. O retorno caiu muito, pois se perdia muito tempo criando modelo. $\mathrm{O}$ retorno era maior quando fazia 10.000 a 20.000 da mesma peça em 40 cores diferentes.

\section{- Empresa G - VIC - Socorro, SP}

Empresa que desenvolve, na maior parte, produtos de malharia retilínea para marcas. Esta empresa tem mais de 10 anos e 40 funcionários, com nove máquinas de tecer e 20 de acabamentos. Encerrou as atividades logo depois da entrevista.

Estilista - Tem uma modelista e uma estilista interna que apoia o desenvolvimento junto as requisições das marcas. Sua produção anual chega a 50.000. Trabalha com produtos muito elaborados para marcas diferenciadas. Durante o período de atividade, a sócia atuava como estilista e modelista, com uma assistente de estilo, uma assistente de modelagem e um programador. O outro sócio também tinha conhecimentos de programação. A coleção própria era desenvolvida a partir da pesquisa de tendências realizada pela estilista. Os croquis eram feitos internamente e adquiridos dos estilistas locais. A maioria dos materiais era mantida de uma coleção para a outra.

Matéria prima - A matéria prima usada pela empresa é basicamente o fio 100\% algodão em cru, quando vai para beneficiamento de tinturaria e lavagens, e suas misturas como o fio Seridó, que é constituído de 50\% algodão e 50\% acrílico, e fio de $100 \%$ acrílico. A malha do VMMR é tecida em cru e depois enviada a uma empresa de tinturaria subcontratada, que tinge em algodão estonado e com variações de técnicas de tingimento. Este processo é longo e requer um cuidado especial na modelagem. 
Tecnologia - Peça depois de pronta e costurada que vai para o beneficiamento da lavanderia, encolhe em média $30 \%$ no comprimento e $10 \%$ na largura, o que leva a necessidade de ser modelada adequadamente. $\mathrm{O}$ molde é calculado com estes parâmetros, e o produto final vai deformado para a lavanderia. O principal cuidado é na curvatura das cavas, decotes e comprimentos. Produtos básicos de qualidade para público masculino e feminino, incluindo lã e algodão tinturado, principalmente para marcas (Private Label) e adicionalmente com marca própria, cuja comercialização era feita por meio de representantes (atacado, sob pedido), e uma loja de fábrica.

\section{- Empresa H - FT - Lindoia}

Empresa familiar de pequeno porte em Lindóia, que havia encerrado as atividades há 4 anos e estava em fase de reabertura por dois dos sócios no momento da entrevistas, há dois anos. Nesse momento de reabertura (2013), a empresa contava com 18 funcionários, 9 máquinas retilíneas automáticas e produção de quase 50 mil peças/ano.

Estilista - A estilista é uma das sócias e os produtos são femininos, predominantemente básicos e de baixo valor agregados, normalmente compostos por fios $100 \%$ acrílico, com alguns detalhes de moda. Uma sócia desenvolve os produtos através de pesquisas em fontes disponíveis na internet, sem regime de coleções estruturadas.

Programação - atividade de programação fica a cargo do outro sócio. Ambos contam com o suporte de uma modelista em dedicação integral. Desenvolvem produtos com base em ficha técnica simples, realizando protótipos, provas e ajustes. Venda no sistema de pronta-entrega através de uma loja (atacado e varejo) e representantes revendedores.

\section{- Empresa I - MG - Monte Sião}

Empresa de pequeno porte, com 22 anos de mercado e 20 funcionários. No momento da entrevista (2013) a empresa estava em fase de ampliação, com a mudança para um novo galpão, onde contava com 7 máquinas retilíneas automáticas. Também conta com duas lojas de atacado e terceiriza a produção na época de alta estação.

Programação - O fabricante é programador e desenvolve os modelos com a ajuda da modelista. O desenvolvimento de produtos não é estruturado com coleções.

Estilista - Compra desenhos de estilistas locais, desenvolve produtos femininos básicos com pequenos detalhes de moda, baixo valor agregado. A base de material é 100\% acrílico com 
adição de alguns componentes em parte da coleção (ex. lurex e detalhes). Trabalha com blusas e casacos de boa qualidade. Sendo que, na maioria peças básicas, mas também desenvolve alguns artigos para clientes varejistas. Venda a atacado através de lojas próprias e revendedores. Ele elimina o designer de moda e o representante com isso tem economia de custos. Utiliza mão de obra de baixo custo e matéria prima básica. O estilo da coleção é baseado nas informações que seus clientes fornecem revistas e sites de moda. O sócio e a modelista acompanham a prototipagem, prova e ajuste, e aprovados pelo sócio.

\section{- EMPRESA J - FA - Monte Sião.}

Empresa familiar, em Monte Sião, de pequeno porte com dois sócios, o empresário é programador e a esposa é a estilista. Com capacidade de 20 mil peças de produção por ano, 9 funcionários e 7 máquinas retilíneas automática. Desenvolvem e produzem para outras marcas (Private Label) e, para comercialização com marca própria em suas duas lojas próprias (atacado e varejo) e revendedores atacadistas. Os produtos utilizam como base, os fios e pontos diferenciados, e trabalho de estamparia, mas em modelagens básicas e intermediárias. O resultado final é de um produto de bom valor agregado e preço intermediário. As coleções próprias são desenvolvidas com base em pesquisas na internet, palestras de moda na região, viagens periódicas. Um dos sócios é também um bom programador e modelista, e conta com o apoio de um programador contratado com dedicação integral e sua sócia com a perspectiva comercial. Não há uma grande variação de modelagens, mas sim de pontos e fios.

\section{D) Visita Técnica a Universidade de Caxias do Sul}

Visita técnica no setor de desenvolvimento de produtos e laboratórios de máquinas de malharia, modelagem, e costura de Vestuário de Malharia Retilínea, 2013.

A Prof. a Maria Da Graça passa didaticamente os primeiros passos, para entender o processo manual de tecer e modelar. Segundo a professora "este estudo é bem simplificado". A peça em Malharia Retilínea começa na escolha dos fios e acaba na peça pronta. Esta peça passa pela montagem na modelagem Moulage para depois ser planificada. O designer é que escolhe os acabamentos e fornece todos os detalhes da ficha técnica. São experimentados vários recursos nas criações e inspiração como crochê, macramê, bordados, trançados, aplicações, barrados, tingimentos, estamparias, processos de silkscreen, e desgastes. 
A Prof. ${ }^{a}$ Leda Stumpf, passou por várias universidades pesquisando o processo de ensino da malharia retilínea como Esmod e Polimoda. Esta modelagem é diferenciada e para executá-la é necessário saber lidar com as especificidades da malha. Dentro desta concepção ela iniciou o trabalho com a modelagem básica plana, e desta base desenvolveu quatro esquemas de traçado, classificada pela elasticidade. Dividiu as bases em baixa elasticidade, média, alta e padrão. O aluno vai aplicar estas bases de acordo com o modelo e material, relacionando com o ponto e fio. Esta classificação tem como base para alunos iniciantes, pois eles não têm experiência para manipular os tecidos diretamente no manequim.

$\mathrm{Na}$ criação da modelagem de peças mais complexas e criativas, é utilizada a técnica de Moulage que no caso da malha, tem a característica da elasticidade e peso do caimento. A professora Leda Stumpf atestou que devido às peculiaridades da malha cada professor trabalha com seu polígrafo. Esta modelagem não tem livro editado, porque ela é diferenciada, não se consegue executar a modelagem sem saber lidar com as especificidades da malha. Nesta Modelagem em malha, não é possível ter padrão como o tecido plano, tem que sentir a elasticidade do tecido, por isso a técnica de modelagem no manequim, Moulage, é a mais adaptada para a execução do modelo.

A professora Leda Stumpf ensina que neste primeiro momento os alunos normalmente tem medo de modelar, principalmente quando é malha, mas com o tempo estas técnicas de modelar vão se tornando familiares e ajudando a experimentar novos materiais e modelos. Estes processos são empíricos e cabe aos futuros estilistas aprender com este processo de trabalho criativo do fazer e exercitar infinitamente sua moldagem e criatividade.

A professora começou a modelar com a primeira máquina eletrônica da região de Caxias do Sul, e desenvolveu seu aprendizado trabalhando com o programador e o tecelão. Estudou o que a máquina é capaz de fazer, tratar com o programador e passar sua criação. Porém, é necessário, nesta interação, o estilista saber os recursos da máquina, estimular o programador a tentar usar os recursos de forma criativa. Às vezes, os erros resultam em pontos inusitados que dão um bom produto. 